MASEC-SCR-80-015

\title{
A CASE STUDY EVALUATING THE POTENTIAL FOR SMALL WIND ENERGY CONVERSION SYSTEMS (SWECS) AS AN INTEGRAL PART OF THE GENERATING MIX OF A REGIONAL UTILITY
}

Final Report, ICFAR Project 05-3-7001-0

\author{
Michael L. Brown
}

Indianapolis Center for Advanced Research, Inc. 1219 West Michigan Street Indianapolis, Indiana 46202

DOE Contract No. DE-AC02-79CS30150 MASEC Contrac No. MA-SC-79-IN00011

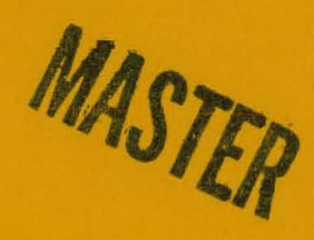

September, 1980 


\section{DISCLAIMER}

This report was prepared as an account of work sponsored by an agency of the United States Government. Neither the United States Government nor any agency Thereof, nor any of their employees, makes any warranty, express or implied, or assumes any legal liability or responsibility for the accuracy, completeness, or usefulness of any information, apparatus, product, or process disclosed, or represents that its use would not infringe privately owned rights. Reference herein to any specific commercial product, process, or service by trade name, trademark, manufacturer, or otherwise does not necessarily constitute or imply its endorsement, recommendation, or favoring by the United States Government or any agency thereof. The views and opinions of authors expressed herein do not necessarily state or reflect those of the United States Government or any agency thereof. 


\section{DISCLAIMER}

Portions of this document may be illegible in electronic image products. Images are produced from the best available original document. 


\section{NOTICE}

This document was prepared as an account of work sponsored by the Mid-American Solar Energy Complex (MASEC), and the U. S. Department of Energy. Neither MASEC, the United States nor any agency thereof, nor any of their employees, makes any warranty, expressed or implied, or assumes any legal liability or responsibility for any third party use or the results of such use of any designs, information, apparatus, product, or process disclosed in this data, or represents that its use by such third party would not infringe on privately owned rights. 


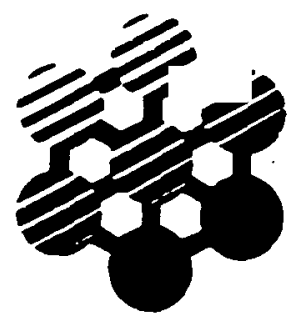

\section{Indianapolis Center for} Advanced Research Inc.

A CASE STUdY EVALUATING THE POTENTIAL gOR

SMALL WIND ENERGY CONVERSION SYSTEMS (SWECS)

AS AN INTEGRAL PART OF THE GENERATING MIX

OF A REGIONAL UTILITY

Final Report, ICFAR Project 05-3-7001-0

Michael L. Brown

Indianapolis Center for Advanced Research, Inc. 1219 West Michigan Street

Indianapolis, Indiana 46202

DOE Contrart iNo. DE-ACO2-79CS 30150

MASEC Contract No. MA-SC-79-IN00011

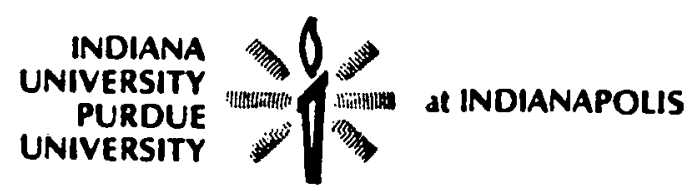

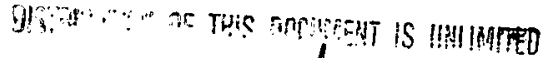




\section{THIS PAGE}

\section{WAS INTENTIONALLY \\ LEFT BLANK}




\section{FOREWORD}

This study, "A Case Study Evaluating the Potential for Small wind Energy Conversion Systems (SWECS) as an Integral Part of the Generating System of a Regional Utility", was funded by the Department of Energy through a contract with the MASEC Corporation (DOE CONTRACT DE-ACO279cs30150) and by a subcontract with the Indianapolis Center for Advanced Research, InC. (MASEC CONTRACT MA-SC-79-IN-0011). The subcontract was awarded in September, 1979 and work was completed in September, 1980. Ms. Janet Adams was MASEC subcontract Administrator at the close of the project.

The Indianapolis Center for Advanced Research (ICFAR), a not-forprofit research institute affiliated with Purdue and Indiana Universities, conducted the major effort of the program, assisted by Public Service Indiana, a regional utility serving 758 of Indiana's counties. 
THIS PAGE

\section{WAS INTENTIONALLY \\ LEFT BLANK}




\section{PROGRAM PERSONNEL}

General program management was under the direction of Dr. G. David Huffman, Director of the Energy Engineering and Research Division of the Indianapolis Center for Advanced Research (ICFAR): Directing activities at Public Service Indiana (PSI) was Mr. C. E. Foggatt, Manager of Research. Mr. Michael L. Brown, ICFAR Staff Scientist, served as principal investigator for the project, and was assisted by Mr. Fereydoon Dadkhah. Also participating in the project,were Mssrs. Dale B. Wilson, Harry Darnell, and Walt Yeager of PSI. Major clerical support was provided by Miss Sue Burkhard and graphics work by Miss Kathleen McDermott, both of ICFAR. Also attending to clerical duties at ICFAR were Mrs. Mary Ann Graf, Ms. Barbara J. Stitts, and Mrs. Barbara Bowen. 


\section{THIS PAGE WAS INTENTIONALLY \\ LEFT BLANK}


TABLE OE CONTENTS

TITLE PAGE

FOREWORD

iii

PROGRAM PERSONNEL

v

TABLE OF CONTENTS

vii

LIST OF FIGURES

$\mathbf{x}$

LIST OF TABLES

xiii

1

1.1

1.1 .1

1.1 .2

LITERATURE REVIEW AND ANALYSIS OF WECS UTILITY APPLICATIONS

Choice of Wind Machines and Sites

Wind Data Requirements and Sources

wind Speed Characteristics

6

a. Wind Speed Frequency and

b. Variation of wind speed with Height

c. Seasonal and Diurnal Vartation of wind Speed.

d. Geographical Variations in wind Speed

e. Statistical Representation of wind Speed Characteristics 
WECS Utility Evaluation 
Section

3

3.1

3.2

3.3

4

5
Title

INTEGRATION OF WECS INTO A REGIONAL UTILITY'S GENERATING SYSTEM

Correlation of Wind Availability and the Utility's Load

Economic Evaluation of Combined WECS and Load Control Systems

Implications of Factoring WECS into the Utility's Proposed Expansion Plans

SUMMARY AND CONCLUSIONS

RECOMMENDATIONS

REFERENCES

REFERENCES FROM DEWINKEL CITED IN THIS REPORT

APPENDICES

A. Wind Speed and Power Density for Indianapolis, 1973-77

B. Public Service Indiana's Ioad for 1979

C. JBF Computer Programs

D. Other Computer Programs

E. Production Cost Simulations
175

179

167

167

169

171

181

183

199

223

227

237 


\section{Figure Number}

1

2

3

4

5

6

7

8

9

10

11

12

\section{Figure Caption}

Wind. Speed - Duration Curves for

Lubbock, Texas at a Height of 30

Meters Above Ground

Average Daily Wind Speed - Per Cent. Duration Curves for Lubbock, Texas and Carlsbad, New Mexico at a Height of 30 Meters Above Ground

Average Daily Power - Per Cent Duration Curves for Lubbock, Texas and Carlsbad, New Mexico at a Height of 30 Meters Above Ground

Hourly Variation of Power Produced by $1 \mathrm{M}$ Turbine Rated at 10 mps at $60 \mathrm{~m}$ Hub Height in Amarillo, Texas During an Average Day of the Month, January through June

Typical Performances of Wind Machines

GE 500-KW WECS Performance Curve

Power Coefficient Versus Wind Speed

for the 500-KW Wind Turbine

Specific Energy Output as a Function of the Annual Average Wind Speed and Rated Power Density of the Wind Machines. (Calculated for the Twelve Airport Sites --black dots. Data Averaged over Six Years.) (DeWinkel)

Power Versus wind speed for GE 500-KW WECS

Wind Turbine Generator Characteristic Curves, All Iosses Included

Falmouth Array and Single-Site Power Level Cumulative Probabilities (GE 500-KW WECS)

Wind Measuring Sites In and Around the State of Indiana
Page Number

7

9

10

18

35

39 
Annual Array-Average Speed ( $\mathrm{m} / \mathrm{s}$ ) by Hour for Indianapolis at a Height of 30 Meters

Flow Chart of Major Components of the Analysis and Ioad Duration Curve

Sensitivity of the Unit Value, CI(X), to the Assumptions in the Economic Analysis, for the First weCs Unit Installed

Difference in 1985 Annual Costs for Reoptimized Mix

Difference in 1985 Annual Costs for the Fuel Saver Mode. to Utility

Difference in 1985 Annual Costs for Fuel Saver and Reoptimized Mix Cases (Even Years Plotted) 
Eigure Number

30

31

32

33

34

35

36
Figure Caption

Calculation of "Equivalent Fuel Costs"

Regional Utility's Coal and ofl

Consumption Versus WECs Penetration

Capacity Factors of Selected Generating Units Versus WECS Penetration

Elements of JBF Economic Analysis of WECS Life-Cycle Savings

Break-Even Capital Cost of Millville 100KW wind Machine with Rated Power Density of $244 \mathrm{w} / \mathrm{m}^{2}$ (1989 Dollars)

Break-Even Capital Cost of NASA/DOE Mod-0 100KW Wind Machine with Rated Power Density of $93 \mathrm{w} / \mathrm{m}^{2}$ (1989 Dollars)

Levelized Annual Fixed Cost as a Function of Levelized Capacity Factor and Combined Levelized Capital Cost and Fixed OsM
Page Number

128

145

148

156

157

163 
Table Number

1

2

3

4

5

6

7

8

9

10

11

12

$13 a$

$13 b$
Table Caption

Page

Number

Wind Speed Parameters Defining the Operating Curve of the GE $500 \mathrm{KW}$ WECS $\left(P_{\mathrm{F}}=0.5 \mathrm{MW}, \mathrm{P}_{\mathrm{f}}=0.9\right)$.

Characteristics of Three Selected wind Machines.

WECS Siting and Interface Cost Sumnary ( $\$ /$ Site in 1976 Dollars).

Wind Data obtained from the National Climatlc Center (NCC) and from Public Service Indiana (PSI), 1948-1978.

Site Anemometer Histories for NCC Primary

55 Stations.

Meteorological Station Coordinates (Public

56 Service Indiana).

Annual 5-Year Average wind Speed and Standard Deviation for Locations In and Around the State of Indiana.

Annual Array Average Speed $(\mathrm{m} / \mathrm{s})$ by Phase and Hour for Indianapolis at a Height of 30 Meters.

Characteristics of Selected wind Turbines.

Iinear Regression Parameters and Capacity Factor of Selected Wind Iurbines at Hub Height at Locations In and Around the State of Indiana.

Capacity Factors of Selected Wind Turbines at Site.

Capacity Factor of Millville 100kw wind Turbine at Locations In and Around the State of Indiana.

PSI Annual Demand and Energy Requirements: Historical, 1962-1980.

PSI Annual Demand and Energy Requirements: Forecast, 1981-2000. 
Table

Number

14

15

16

17

18

19

20

21

22
Table Caption

Relationship of Monthly Peak Loads to the Annual Peak Load. (Public Service Indiana).

PSI Conventional Equipment Mix, Year 1990.

126

PSI Conventional Equipment Mix Categorized by Load Type, Year 1990.

Equivalent Diurnal Minimum Run Times for the Generating Units of the Regional Utility.

WECS Operating Reserve Requirements.

Capacity Credit Calculations for Various on-Line Levels of WECS.

Fixed Cost Savings From Credited Capacity of WECS (Thousands of 1990 Dollars).

Heat Content of Coal, Oil, and Nuclear Fuel.

Regional Utility's Fuel Usage as a Function of WECS Capacity.

Annual Capacity Factors of Selected Units for Various Levels of WECS Penetration.

The 1990 Available Funds for the Millville 100KW Wind Turbine. (Thousands of 1990 Dollars).

Analysis Scenario.

The 1990 Present Value of the Total 30

Year Savings.

The 1989 Installation and Unit Values of

the WECS for the 30-Year Analysis.

Busbar Costs for a wind Turbine with Millville 100KW Performance Characteristics.

Correlation Coefficients for Cross-Correlation of hourly Wind Power Density at Indianapolis and Public Service Indiana's Load, 1975-1977.
138

141

122

130 
1. Literature Review and Analysis of SWECS Utility Applications

of recent studies that have evaluated WECS as a part of a utility generating mix, three have been selected for use in the present study. Each study includes a segment for the evaluation of the wind resource and one for the utilization of wind power by an electric utility. Standard utility cost of production and reliability models are used. The three studies are listed below:

- Carel C. DeWinkel, An Assessment of Wind Characteristics and Wind Energy Conversion Systems for Electric Utilities

- JBF Scientific Corporation, Wind Energy Systems Application to Regional Utilities

- Cleon Ligon, et al., Southwest Research Institute, Operational, Cost, and Technical Study of Large Windpower Systems Integrated with an Existing Electric Utility 


\subsection{Choice of wind Machines and Sites}

\subsubsection{Wind Data Requirements and Sources}

Wind data on an hourly (or shorter) basis for a period of at least five years must be obtained for each location where a wecs is to be evaluated. ${ }^{I}$ It is desirable to have the wind data averaged over short time periods, such as the "spot" observation of the National Weather Service (NWS), defined as a one minute average of the anemometer display or trace as estimated by the observer at the time of the record. If only three hourly data is available (observations recorded every three hours), then the required data period should be increased to ten years. Data obtained from several locations can be used to identify regions with large wind resources (and so locate prospective WECS sites) and to perform an economic evaluation of WECS. The National Climatic Center (NCC), Asheville, North Carolina, collects and processes meteorological data from within the United States. ${ }^{2}$ The observations are made by the National Weather Service, Federal Aviation Administration, military services, merchant marine vessels, Coast Guard stations, and some locally operated airfields. ${ }^{3}$ The majority of the NCC observations are made at airport and city locations, whose climatology can be somewhat different from that of surrounding locations. Wind data is recorded hourly as one minute averages on the hour. The height of the wind observations vary from 3m to $30 \mathrm{~m}$, although since 1965 the height is about $6 \mathrm{~m}$ (20 feet) above the ground in the runway area of airports. 4 Most of the hourly data up to 1964 is digitized. Beginning in 1965, only three hourly observations are digitized, although original hourly paper logs are also available. For some stations, hourly digitized records were made for certain periods after 1964. 
Some deficiencies in the NCC wind data have been noted in the literature. As has been mentioned above, only three-hourly observations are available for certain periods at some sites. Still worse, data may be available for only a certain time of the day, such as from 7 a.m. to 10 p.m. 5 The NWS currently installs wind anemometers on light towers or poles located a substantial distance from trees, buildings, shrubs, or other structures which may cause a disturbance in the wind. Formerly, this was not the case. Anemometers were often located on short towers placed atop a hanger, control tower, or other building. Some of the wind observations taken under these conditions could be grossly inaccurate due to the aerodynamic distortion of the anemometer wind regime caused by the presence of the building or nearby trees and other obstacles. In the absence of irformation to the contrary, the credibility of early wind records (pre-1960's) must, in general, be considered less than that of later records. 6

Another source of wind data is electric utility companies. Utilities have meteorological monitoring programs on sites of proposed and operating power plants. 7 This data may be hourly or even quarter-hourly. 8

Dewinkel cites a shortcoming in the usefulness of hourly wind speed observations for wind energy applications: 9

The NCC hourly wind speed observations are one-minute averages once each hour. Studies indicate that the true hourly averaged wind speed is somewhat greater than the average as it is now measured. The gustiness at the location considered is influential here (Lettau and Haugen 1957). Since the power in the wind is a function of the wind speed cubed, an average wind speed does not give the true value of the power in the wind. The reported hourly wind produces an underestimation of the power in the wind (JBF 1977a). According to studies by the Electrical Research Association in England during the 1950s, this underestimate is less than 108 (Changery 1975). 
He further comments, "There appears to be general agreement among students of wind energy applications, that the quality of these wind speed observations is only sufficient for an approximation of power output of wind machines." 
NOTES (1.1.1)

1. DEW, 15. JBFI, 3-1. SWRI, 8.

2. National Climatic Center/Federal Building/Asheville, NC 28801/ Phone (704) 258-2850. Magnetic tapes of meteorological data collected at primary stations (TD-1440 AIRWAYS SURFACE OBSERVATIONS) are available for $\$ 60.00$ each from the digitized data section. Local Climatological Data Annual Summaries may be obtained for $\$ 3.00$. The annual summaries contain the history of the site location (latitude, longitude), the anemometer height history, and a description of the local climatology.

3. DEW, 15: (Changery 1975).

4. DEW, 15. DeWinkel uses $7 \mathrm{~m}$, although 20 feet is closer to $6 \mathrm{~m}$.

5. JBFI, 3-4.

6. SWRI, 10.

7. DeWinkel reports that "Observations required by the Department of Energy on proposed nuclear power plant sites are documented and available from Batelle Northwest Laboratories (Verholek 1977)."

8. Public Service Indiana records meteorological data in quarter-hourly reports with hourly averages. Wind speed is recorded in units of miles per hour.

9. DEW, 15: (Lettau and Haugen 1957), (JBF 1977a), (Changery 1975). 


\subsubsection{Wind Speed Characteristics}

a. Wind Speed Erequency and Duration Curves

A useful means of organizing a wide range of wind speed observations from a given site is the speed-frequency histogram. Observations are distributed into classes and compiled in terms of the time for which a given wind speed was recorded. The results are displayed in a histogram: wind speed on the horizontal axis and the number of hours of each wind speed class on the vertical axis. Because wind records report integer values, usually in knots, it is convenient to use this same unit of measurement for the data compilation. Conversion to another unit, such as meters/second, may be done subsequently.

By suming the data used for the histogram, one obtains a wind speed duration curve. Wind speeds are compiled in terms of time or percent time duration for which a given wind speed was equaled or exceeded. Duration of wind speed $v \geq v_{i}$ appears on the horizontal axis as hours or percentage of the time period considered, and the wind speed $v_{i}$ appears on the vertical axis. The longer the time for which a certain wind speed occurs, the flatter the curve at that point. Very high and very low winds, which generally blow for only a short time, produce the steep regions at either end of a duration curve.

Sites with approximately the same average annual wind speed generally have wind speed duration curves of a similar shape. ${ }^{I}$ Curves at a particular site do show a diurnal variation. As would be expected, nighttime curves are of lesser magnitude than daytime curves (Figure 1). ${ }^{2}$ The shape of the wind speed duration curve reflects the statistical distribution of wind speed with time, and in some geographic regions that 


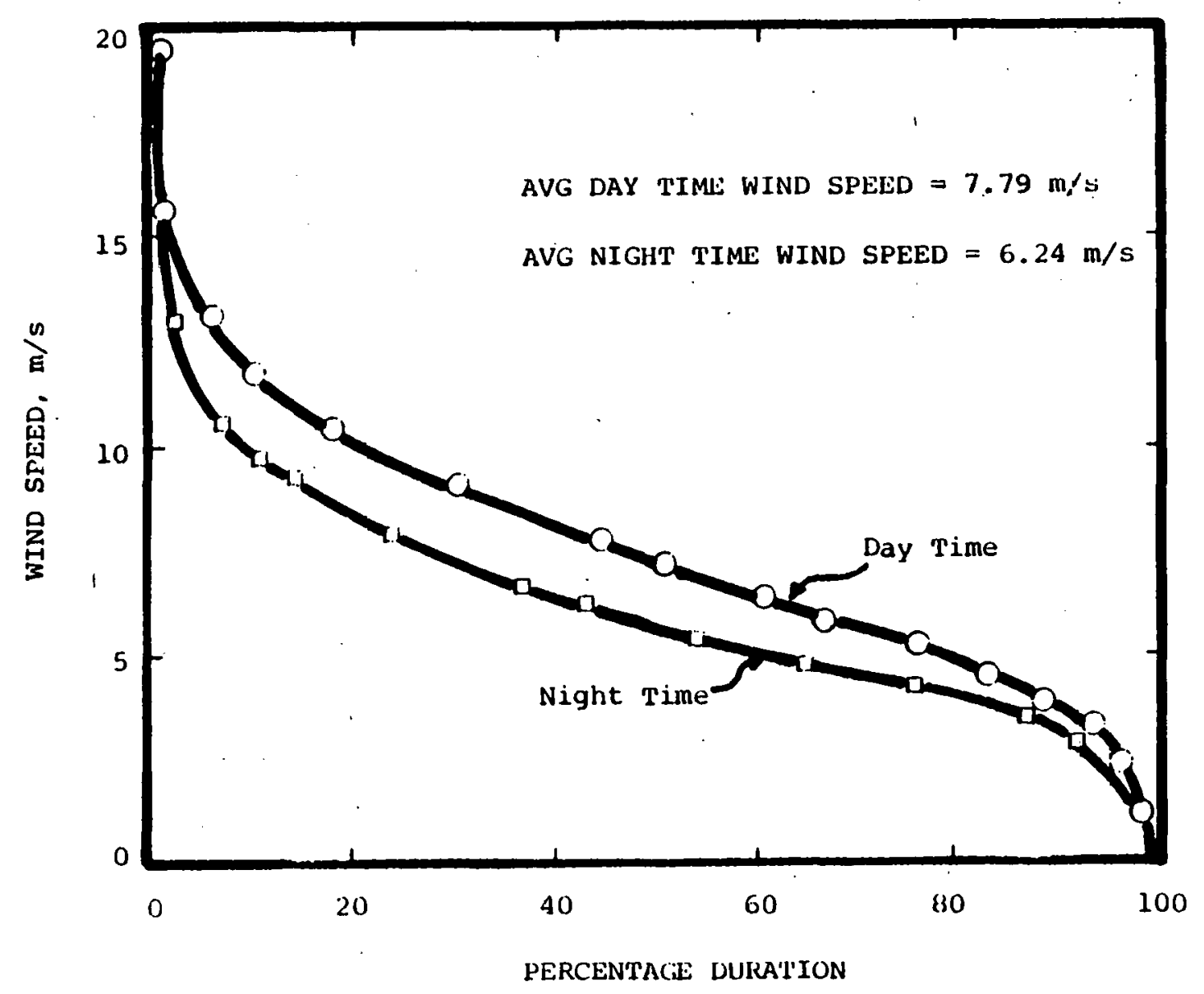


distribution can vary significantly from location to location. ${ }^{3}$ This variation can in turn have a significant effect on the available wind power. Figure 2 compares the wind speed duration curves of Lubbock, Texas, and Carlsbad, New Mexico. ${ }^{4}$ Note the crossover of curves for wind speeds above $10 \mathrm{~m} / \mathrm{s}$. This means that Carlsbad experiences high winds $(>10 \mathrm{~m} / \mathrm{s})$ a greater percentage of the time, even though Lubbock has a 10 percent greater average annual wind speed. Due to the cubic relation of power in the wind to wind speed, the average wind power density at Carlsbad turns out to be six percent higher than that at Lubbock. Figure 3 compares the wind power duration curves for the two locations. 5 Note also that the cube of the wind speed is 23 percent lower at Carlsbad than at Lubbock. These results demonstrate that the average wind speed at a location will not provide a reliable assessment of the actual power density of the wind. Note further from Figure 3 that average wind power density will not provide a reliable assessment of wind power utilization by a given wind turbine generator (WTG). Statistical distribution functions should be used, if at all possible, in WECS performance evaluations. 


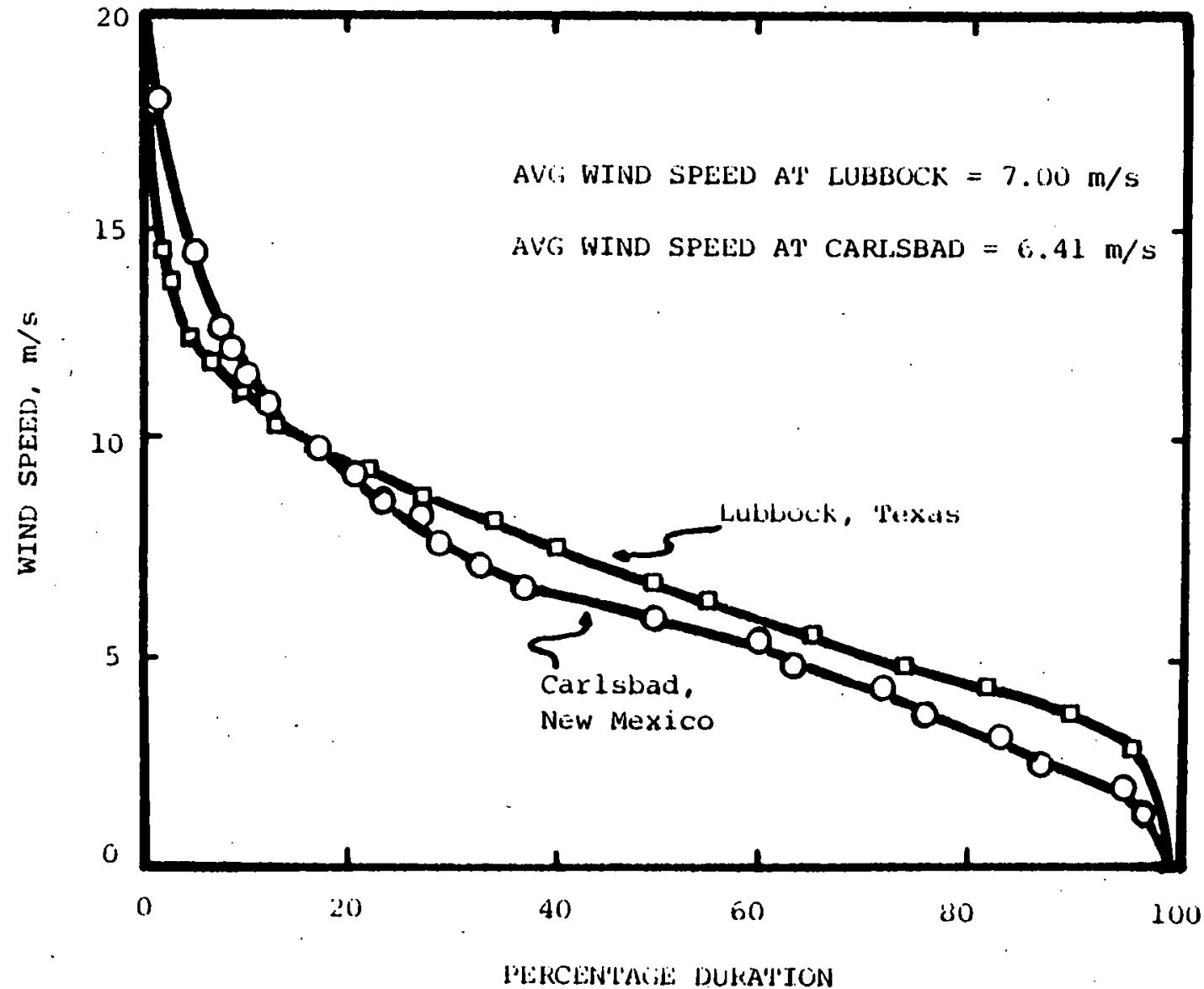




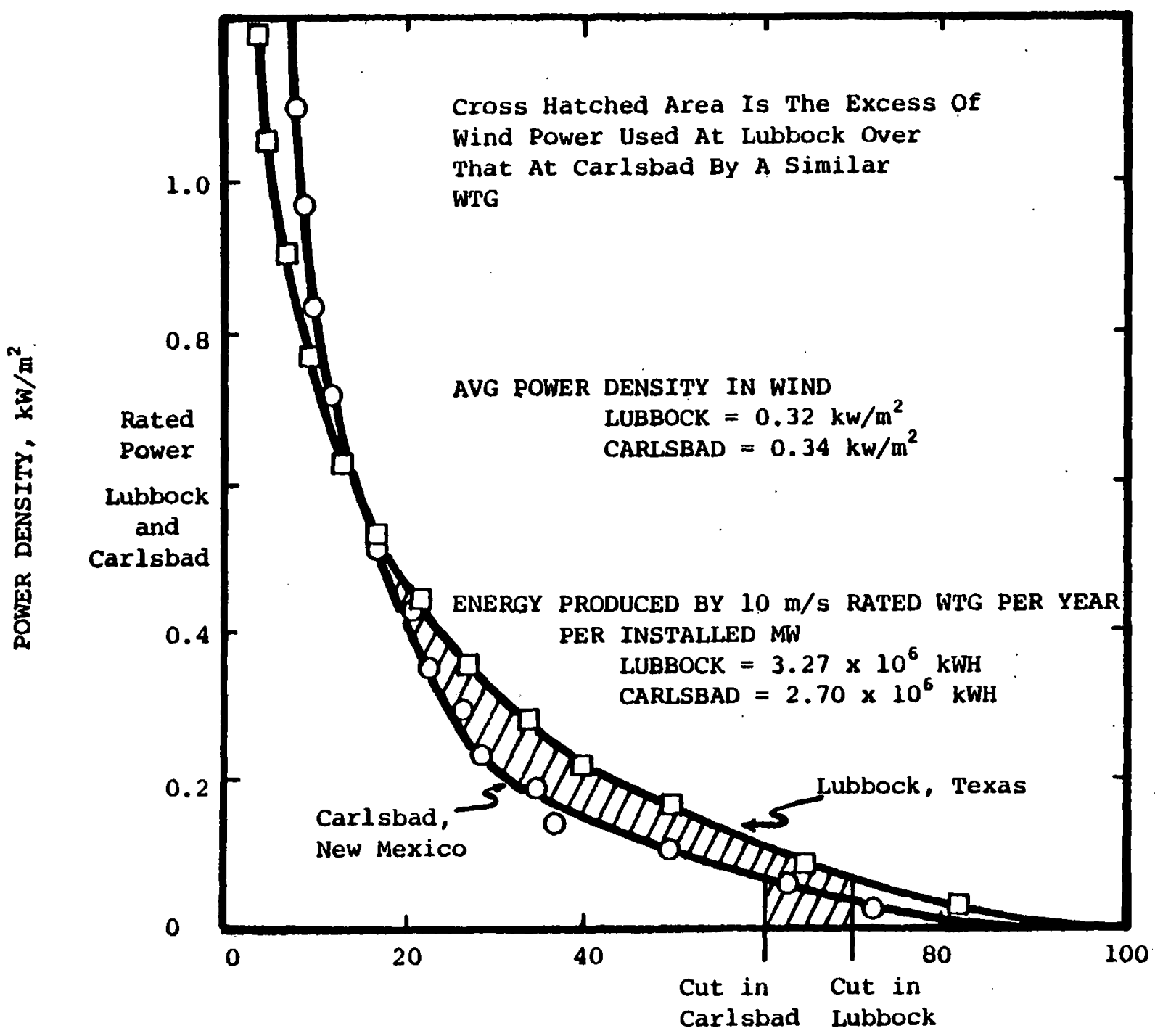

PERCENT DURATION 
NOTES $(1.1 .2 a)$

1. DEW, 16: Findings of an Extensive Wind Survey by the Electrical Research Association in England (Golding and Stodhart 1952; Tagg 1957).

2. SWRI, 17 (Figure 3).

3. SWRI, 16.

4. SWRI, 19 (Figure 5).

5. SWRI, 20 (Figure 6). 


\section{(1.1.2 Wind Speed Characteristics)}

b. Variation of Wind Speed with Height

Wind speed generally increases with height. Several different analytical expressions have been developed for describing this variation. Some of these are discussed below.

DeWinkel cites two expressions often used to describe the variation of mean wind speed $\mathrm{V}$ with height $\mathrm{z}:^{1}$

$$
\begin{aligned}
& \text { Simple Power Law: } \quad \mathrm{v} \sim \mathrm{z}^{\mathrm{a}} \\
& \text { Logarithmic Law: } \quad \mathrm{v} \sim \log \left(1+\mathrm{z} / \mathrm{z}_{0}\right) \text {, }
\end{aligned}
$$

where $a$ is a constant and $z_{0}$ is a length that is called the roughness parameter of the ground surface. The exponent a depends on terrain features, atmospheric stability, distance from ground, and overall air flow. Ițs value varies between 0.05 and $0.5 .^{2}$ Different values of a have been observed for daytime and nighttime, the nighttime value usually being somewhat larger. The aerodynamic roughness parameter $z_{0}$ in the logarithmic law varies dramatically with the type of terrain and to a lesser extent with the time of year. Roughness is higher during summer than during winter. 3

Evaluation of the 1/7-power law has shown it to provide a satisfactory approximation of the wind speed increase with height over flat terrain, such as at airport sites." A close similarity has also been found between the 1/7-power law and the logarithmic law with a 0.03 meter roughness length. For these reasons DeWinkel chooses the simple power law with exponent $1 / 7$ as adequate for the wind energy analysis of his study.

A source of inconsistency between meteorological sites is that wind speed is measured at anemometer heights which vary from station to station and may even vary at a given station during the period of a study. The 
JBF study seeks to overcome this difficulty by placing all of the wind data on a common basis so that relative performance of WECS could be evaluated at different sites. This is accomplished by projecting the wind speed data from anemometer height $z_{a}$ to either hub height, $z_{h}$ ! or to a 10 meter level. The following relations apply: 5

$$
\begin{aligned}
v_{h} & =v_{a}\left(z_{h} / z_{a}\right)^{n} \\
v_{10} & =v_{a}\left(10 / z_{a}\right)^{n}
\end{aligned}
$$

where, the exponent $n$ was considered to be variable with the measured wind speed $v_{a}$, at the anemometer height, through the relationship: ${ }^{6}$.

$$
\mathrm{n}=\mathrm{a}+\mathrm{b} \ln \mathrm{v}_{\mathrm{a}}
$$

where the coefficients $a$ and $b$ are given by

$$
\begin{aligned}
& a=0.37 /\left[1-0.0881 \ln \left(z_{a} / 10\right)\right] \\
& b=-0.0881 /\left[1-0.0881 \ln \left(z_{a} / 10\right)\right]
\end{aligned}
$$

For the values of constants as given in the above equations, the speed $\mathrm{v}_{\mathrm{a}}$ must be in meters/second and the anemometer height $\mathrm{z}_{\mathrm{a}}$ must be in meters.

The Southwest Research Institute (SWRI) study uses a combination of power law and logarithmic relation to describe the height extrapolation: ${ }^{7}$

Wind speed normally increases with the height as a function of both atmospheric lapse rate and surface roughness. Empirical investigations of the relationship of wind speed with height have demonstrated that the vertical profile data can be adequately treated with only two divisions of atmospheric stability conditions, namely stable and unstable(22). The former consists of inversion, isothermal and adiabatic conditions described by the power law relation $(9)$,

$$
U_{S}=U_{r, S}\left(h / h_{r}\right)^{a} \quad \text { for stable conditions. }
$$

The latter condition is well described by the logarithmic relation (7)

$$
U_{u}=U_{r, s} \frac{\operatorname{Ln}\left(h / z_{0}\right)}{\operatorname{Ln}\left(h_{r} / z_{0}\right)} \text { for unstable conditions. }
$$


where

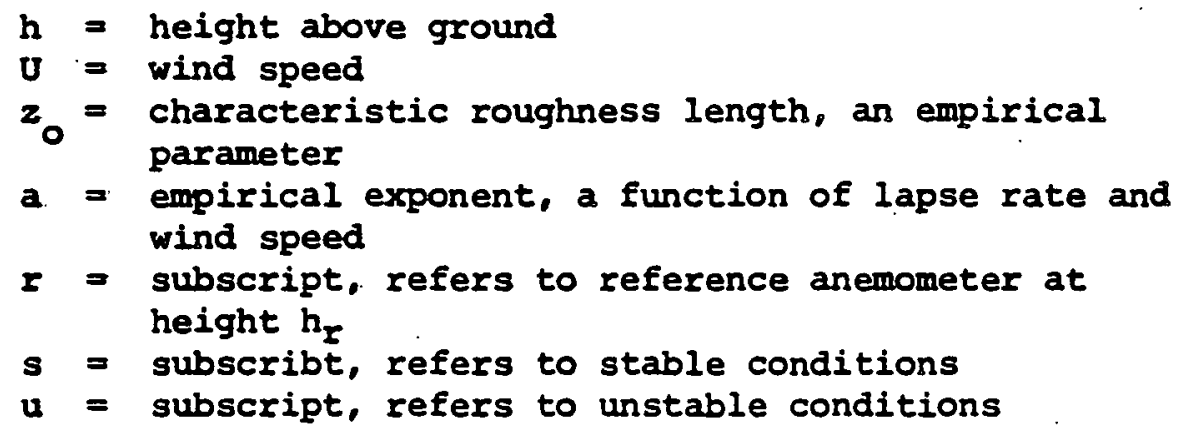

Separate relations are developed for night and day. The night period wind speed, $U_{N}$, being inversion weighted ( 30 percent stable conditions), is given by the relation

$$
\sigma_{N}=0.7 U_{u}+0.3 u_{s}
$$

The day period, during which stable conditions rarely occur, is height extrapolated using the following equation

$$
\mathrm{U}_{\mathrm{D}} \doteq \mathrm{U}_{\mathrm{U}}
$$

The characteristic roughness length $z_{0}$ is an empirical constant which should be locally evaluated because it is a function of the local terrain geometry and of the type of ground cover. ${ }^{8}$ The fitting of wind data taken at two different heights at Lubbock, Texas, to the logarithmic relation yielded a $z_{0}$ value of $6 \mathrm{~cm}$, which corresponds to a surface covered by long to medium height grasses. Since this description of ground cover is comparable to that of Lubbock and most of the utility service area, the $6 \mathrm{~cm} \mathrm{z}_{0}$ value was used for all data stations in the study. The exponent $a$ in the height extrapolation equation for stable conditions is a function of both wind speed and lapse rate. For the SWRI study, the lapse rate selected was the 0600 CST average Amarillo, Texas value of 
$0.18^{\circ} \mathrm{C} / 100$ meters. Using that lapse rate, the following set of linear equations was determined from empirical data:

$$
a=\left\{\begin{array}{lr}
0.557-0.0316 U_{r} & 1 \leq U_{r} \leq 11 \\
0.325-0.01 U_{r} & 11 \leq U_{r} \leq 18 \\
0.15 & U_{r} \geq 18
\end{array}\right.
$$

where $U_{r}$ is in knots. 
1. DEW, 16.

2. DEW, 16: (Reed 1975; Lettau and Hagen 1957).

3. DEW, 17: (Kung and Lettau 1961).

4. DEW, 17: (Reed 1976a and 1976b).

5. JBFI, D-1.

6. JBFl, D-1: [7] Justus, C.G. and Amir Mikhail (1976): "Height Variation of Wind Speed and Wind Distribution Statistics". Geophys. Res. Letters, 3, 261-64.

7. SWRI, 11: [22] Southwest Research Institute Proposal No. 15-497, "Operational, Cost and Technical Study of Large Windpower Systems Integrated with Existing Electric Utilities," 12 July, 1974. Appendix B.

[9] Thuillier, R. and Lappe, U.O., "Wind and Temperature Profile Characteristics from Observations on a $1400 \mathrm{ft}$. Tower," J. Applied Meteorology, Vol. 3, pp. 299-306, June 1964.

[7] Davidson, B., et al, Sites for Wind-Power Installations, World Meteorological Organization, Tech. Note No. 63, WMO-No. 156 TP. 76, 1964.

8. SWRI, 13. 


\section{(1.1.2 Wind Speed Characteristics)}

c. Seasonal and Diurnal Variation of wind Speed

The availability of wind for the production of electrical power varies with the time of day and the season of the year. The SWRI study (Texas panhandle region) observes that winds are generally expected to be higher in the afternoon and in the spring than at other times. ${ }^{1}$ This observation also applies to the Great Lakes region. 2 DeWinkel points out the influence of solar radiation and the land-sea interface upon variation in wind speed. 3

The degree of hourly and seasonal variation of the average wind may be quantized using hourly or 3-hourly wind speed data. In the SWRI study, the following computations were made for the Amarillo, Texas wind data in order to determine daily and seasonal power variability:

a. The 3-hourly wind speeds for the period January, 1962 through December, 1972 were collected and a wind speed-duration function tabulated for each of the hours 0000, 0300, 0600, 0900, 1200, 1500, 1800 and 2100 throughout a given month over the 10-year interval. Thus were obtained 8 speedduration curves ( 3 hour intervals) for each of the 12 months of the year.

b. Each speed-duration curve was height adjusted by the usual way to various heights, and by the cubic relation, power-duration functions formed. WTG performance characteristics were applied to each power-duration function and integrated to obtain the average power output for the machine at each hour of an average day of the month.

c. 'Thèse average hourly variation curves were integrated to obtain the expected energy output per installed $\mathrm{KW}$ for each month.

Figure 4: shows the hourly electric power which could be produced by a one megawatt wECS rated at $10 \mathrm{~m} / \mathrm{s}$ erected to a turbine hub height of 

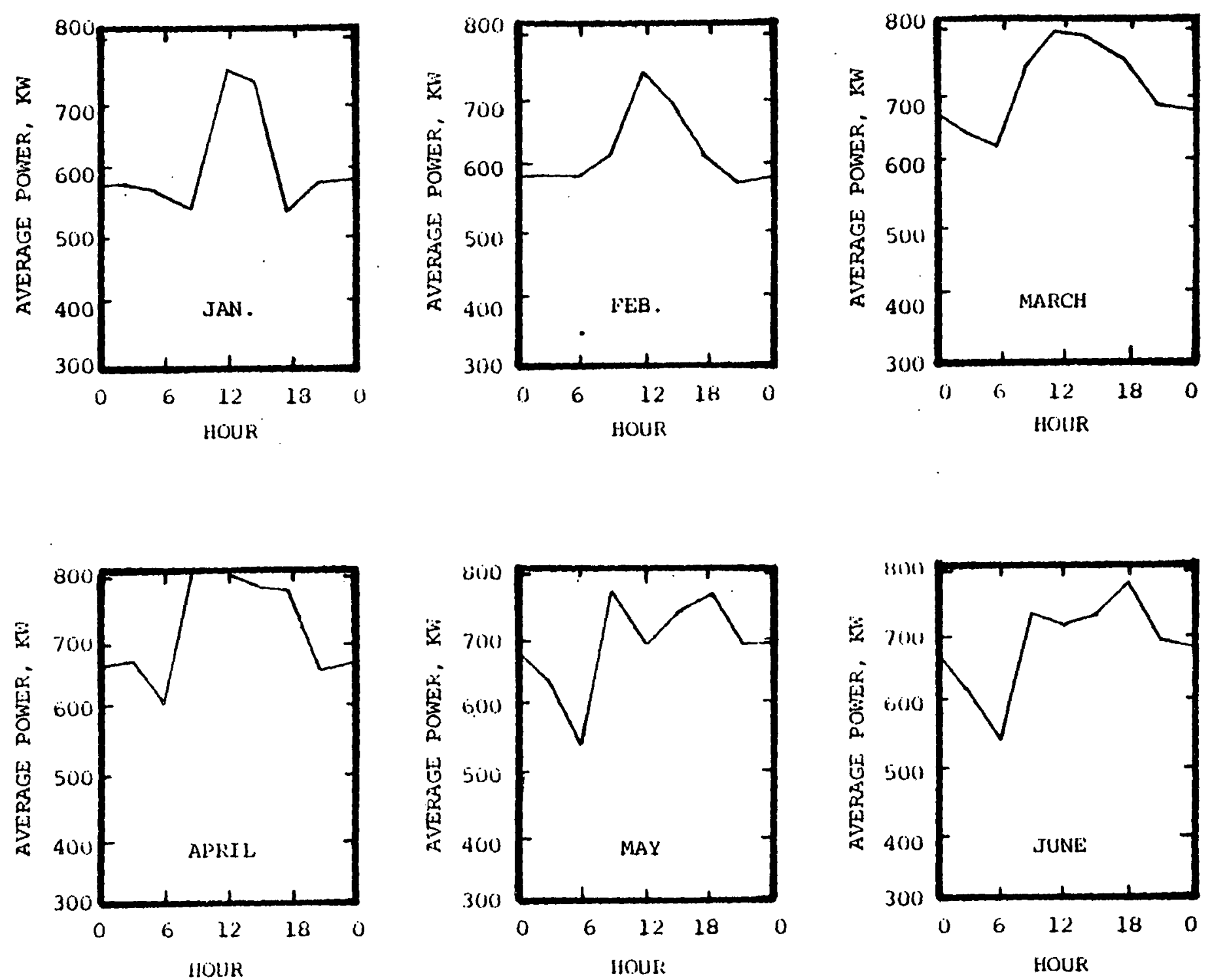

焉置

要


60 meters during the months of January through June. 5 From a year's worth of these plots the average monthly power production of a WECS could be determined. In the SWRI study, the maximal deviation from the mean of expected monthly wind power was found to be only 16 percent. "The extractable energy from the wind of West Texas is therefore quite seasonably reliable and unexpectedly uniform." 6

The average annual wind speed tends to be relatively constant over a long time period. Wind speed data of about 5 to 10 years is therefore sufficient for an evaluation of the long term performance of a particular WECS. DeWinkel remarks, "The evidence found suggests that wind is a constant and reliable power source, as long as the short-term variations within the month can be equalized." 7 
NOTES $(1.1 .2 c)$

1. SWRI, 31 .

2. DEW, 17, 18.

3. DEW, 18.

4. SWRI, $31,42$.

5. SWRI, 43 (Figure 22).

6. SWRI, 42 .

7. DEW, 19. 


\section{(1.1.2 wind Speed Characteristics)}

\section{d. Geographical Variations in wind Speed}

Topography can have a substantial influence on wind speed. Among the geographical features which affect wind are hills, ridges, large bodies of water, and ground cover. The presence of hills or. ridges may speed up the wind by a factor of up to 1.5 or lower it by factors as low as 0.71 , depending on topographical conformation, wind speed and direction, atmospheric stability, and other factors. ${ }^{1}$. The type and height of ground cover also influences the wind boundary layer. Buildings and tall trees create local turbulence and energy dissipation. These effects are decreasing functions of height within the boundary layer. Ground roughness may vary seasonally and from one part of a region to another due to the nature of the plant cover. ${ }^{2}$ The presence of a large body of water can also significantly influence the winds of a region. ${ }^{3}$

The degree of topographic relief and the height and type of ground cover are major factors effecting the validity of interpolation of wind data between recording sites. Interpolation is expected to be quite good for relatively smooth plain terrain with uniform natural ground cover. The presence of mountainous or heavily forested terrain would invalidate the interpolation.

Regional wind contours are helpful in identifying areas within regions of high wind resource that meet the various engineering, economic, environmental, and other constraints on prospective wECS sites. If the region is uniformly smooth of terrain and of uniform ground cover, then contours may be drawn by estimation based on linear interpolation ainong 
data stations. 4 The presence of non-uniform geographical features may call for a multiple linear regression analysis of the wind data. Such an analysis was carried out for the JBF study (southeastern Massachusetts area), based on the assumption that the mean wind speed could be accounted for by variations in site elevation (above sea level), site terrain relief, and distance of the site from the coast. 5 The terrain relief was here defined as "the difference between the site elevation and the lowest elevation occurring within a $1 \mathrm{~km}$ radius". 
NOTES $(1.1 .2 \mathrm{~d})$

1. SWRI, 7.

2. DEW, 20 .

3. DEW, 19.

4. See SWRI sections II.A.4 and II.B.2.

5. JBF1, Appendix C. 


\section{(1.1.2 Wind speed Characteristics)}

\section{e. Statistical Representation of Wind Speed Characteristics}

In order to handle the large amount of wind data necessary for the evaluation of regional wECS, it is helpful to form a statistical description of wind speed characteristics. Once this is done, sites may be evaluated in terms of the statistical parameters rather than having to go back to the raw data. Of the two statistical functions with two parameters which have been used to describe wind speed distributions, the Weibull and the log-normal, the Weibull distribution has proved to be superior. 1

Mean wind speed and standard deviation may alternatively be used to characterize wind speed data. As was pointed out above (section 1.1.2a), due to the cubic relation of wind power to wind speed, statistical distributions are to be preferred to average wind speed in assessing wind power density.

Finally, although statistical descriptions of wind speed or wind power are useful for certain WECS evaluations, the original time series wind speeds are preferred for WECS utility applications, wherein hourly load and wind speed data are used. A positive correlation between hourly wind distributions and electrical load requirements could affect the way in which wECS are incorporated into a utility power grid. 
NOTES $(1.1 .2 e)$

1. DEW, 21: (Justus 1976; Tackle and Brown 1976). 
1.1 Choice of wind Machines and Sites

\subsubsection{Wind Power Density}

The kinetic energy flux of the wind, named the wind power density, is given by

$$
E=4 \rho v^{3}
$$

where

$$
\begin{aligned}
& \rho \text { is the air mass density } \\
& U \text { is the wind speed }
\end{aligned}
$$

With a standard sea-level air density of $1.2 \mathrm{~kg} / \mathrm{m}^{3}$, wind power density is ${ }^{1}$

$$
E_{\left(W / \mathrm{m}^{2}\right)}=\left\{\begin{array}{l}
0.61 \times \mathrm{U}^{3}, U \text { in } \mathrm{m} / \mathrm{s} \\
0.054 \times \mathrm{U}^{3}, U \text { in mph } \\
0.083 \times \mathrm{U}^{3}, U \text { in knots }
\end{array} .\right.
$$

The need for wind distribution functions is made evident by this third power of wind speed in the wind power calculations. Clearly, the power in the mean wind speed $\bar{U}$ is in general significantly lower than the mean of the wind power, i.e.,

$$
\begin{gathered}
\bar{U}=\frac{1}{N} \sum_{i=1}^{N} U_{i} \\
E_{\bar{U}}=\frac{1}{2} \rho \bar{U}^{3} \leqq \frac{1}{N} \sum_{i=1}^{N} \frac{1}{2} \rho U_{i}^{3}=\bar{E}
\end{gathered}
$$

The ratio of mean power in the wind to power in the mean wind is called the energy pattern factor $f$, and is given by

$$
f=\frac{\bar{E}}{E_{\bar{v}}}
$$

The average wind power density $\bar{E}$ may be computed by numerical integration of tabular wind power duration functions. 2 


$$
\bar{E}=\frac{1}{T} \int_{0}^{T} E d t
$$

where

$$
t \text { is time }
$$

$T$ is total period of record

Distributions of wind power density throughout a region may be displayed by means of contour lines of equal wind power density. Since wind power varies with the cube of wind speed, the relative differences between sites will be much greater for these contours than for those of wind speed. 
NOTES $(1.1 .3)$

1. DEW, 22 .

2. SWRI, 14 . 


\subsection{Choice of wind Machines and Sites}

\subsubsection{WECS Power Output}

The efficiency with which a wind turbine extracts power from the wind may be measured by a parameter called the power coefficient, $C_{p}$ ' defined as:

$$
C_{p}=\frac{\text { power output from machine rotor }}{\frac{1}{2} \cdot \rho \cdot A \cdot V^{3}}
$$

where

$$
\begin{aligned}
& \rho \text { is the mass density of the air } \\
& A \text { is the area swept by the blades } \\
& V \text { is the free-stream wind speed }
\end{aligned}
$$

The theoretical maximum $C_{p}$ has been shown by Betz to be $16 / 27$, or 0.593 .1 The power coefficient of a wind turbine rotor varies with the ratio of blade tip speed to speed of the wind stream. Figure 5 shows the power coefficient versus tip speed ratio curves for several types of wind machines. ${ }^{2}$ Notice that the high speed two blade type and Darrieus rotor yield the highest efficiencies of wind power extraction.

$$
\begin{aligned}
& \text { The capacity factor } F_{p} \text { of a wind machine is defined as } \\
& \qquad F_{p}=\frac{\bar{P}}{P_{Y}}
\end{aligned}
$$

where

$$
\begin{aligned}
& \bar{P} \text { is the average power output for a given period } \\
& { }{ }_{r} \text { is the rated power output }
\end{aligned}
$$

The specific energy output $E_{S}$ for a given period of $H$ hours is given by

$$
E_{S}=H \times \frac{\bar{P}}{P_{r}}=H \times F_{P} \quad(k W h / k W / t i m e \text { period })
$$

For calculating annual specific energy output, $H=8766$ hours. 


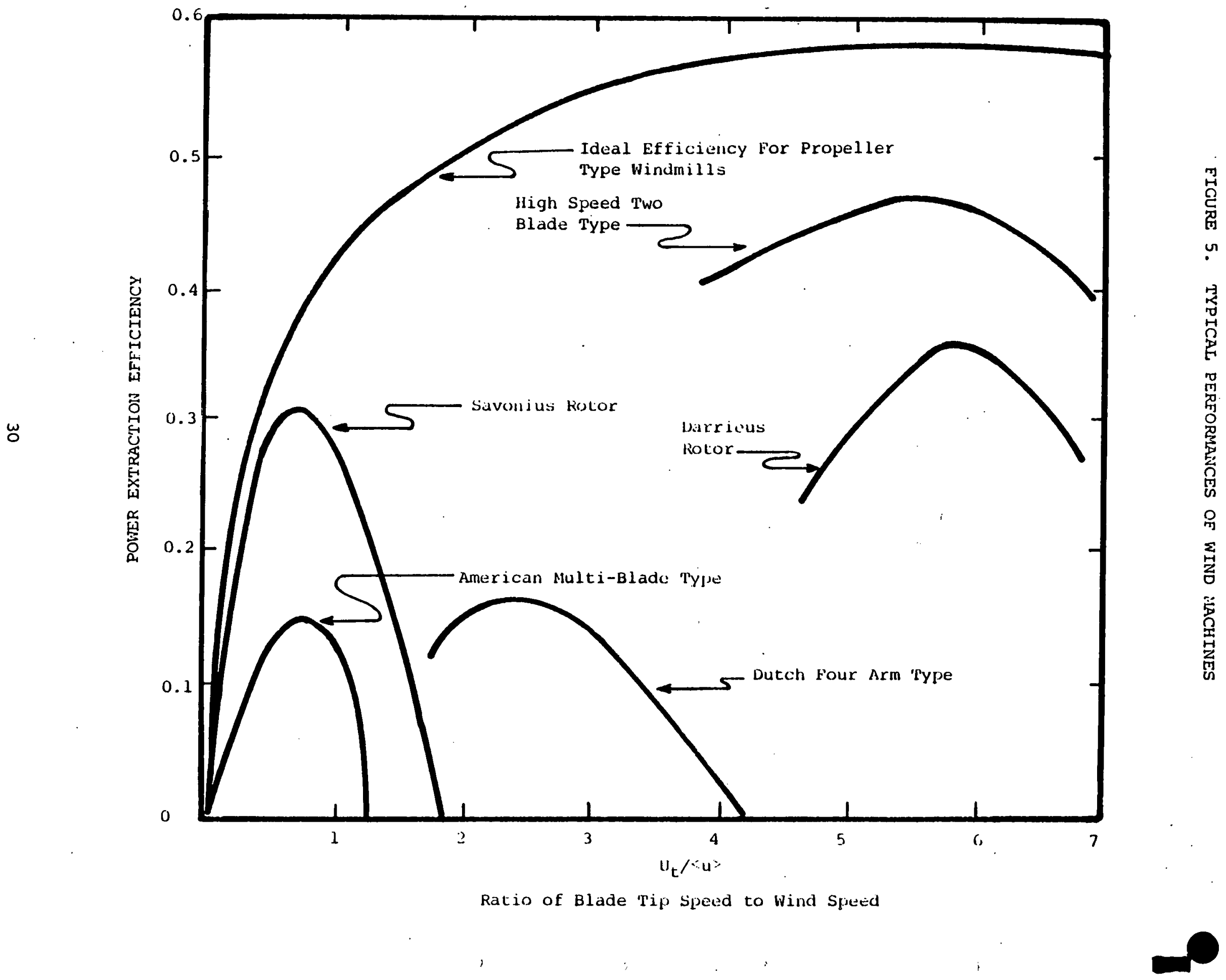


The power output of a particular wind turbine is a function of both its wind environment and its performance characteristics. The basic design performance characteristics of the WECS used in the JBF study are recounted below: ${ }^{3}$

\section{E. 2 BASIC WECS PERFORMANCE CHARACTERISTICS}

In a uniform axial flow speed, $v_{h}$, at standard mass density $\rho_{0}$ with power coefficient, $C_{p^{\prime}}$ and rotor swept area, $A$, the shaft power output, Po' of a WEC unit would be

$$
P_{\circ}=0.5 C_{p} \rho_{0} V_{h}^{3} A
$$

When $C_{p}$ variations as a function of speed and blade pitch angle, mechanical and electrical losses, etc., are taken into account, the electrical power output of a WECS can be reasonably approximated by the relations

$$
\begin{array}{cll}
0 & v_{n} \leq v_{\text {in }} \\
P\left(v_{h}\right) / P_{r}=A+B v_{h}+C v_{h}{ }^{2} & v_{\text {in }} \leq v_{h} \leq v_{r} . \\
1 & v_{r}<v_{h} \leq v_{\text {out }} \\
0 & v_{h}>v_{\text {out }}
\end{array}
$$

where:

$$
\begin{aligned}
& v_{h}=\text { wind speed }(\mathrm{m} / \mathrm{s}) \\
& v_{\text {in }}=\text { wECS cut-in speed }(\mathrm{m} / \mathrm{s}) \\
& v_{r}=\text { wECS rated speed }(\mathrm{m} / \mathrm{s}) \\
& v_{\text {out }}=\text { wECs cut-out speed }(\mathrm{m} / \mathrm{s}) \\
& P_{r}=\text { rated power } \\
& P_{h}=\text { output power (Mw) }
\end{aligned}
$$

and $A, B$, and $C$ are coefficients determined by the three conditions

$$
\begin{aligned}
& P\left(V_{i n}\right) / P_{r}=A+B V_{i n}+C V_{i n}^{2}=0 \\
& P\left(V_{r}\right) / P_{r}=A+B V_{r}+C V_{r}^{2}=1 \\
& P\left(V_{m}\right) / P_{r}=A+B V_{m}+C V_{l u}^{2}=P_{m} / P_{r}
\end{aligned}
$$


where

$$
\begin{aligned}
& v_{m}=\left(v_{i n}+v_{r}\right) / 2(m / s) \\
& P_{m} / P_{r}=P_{f}\left(v_{m} / V_{r}\right)^{3} \\
& P_{f}=\text { adjustment factor }\left(0.9<P_{f}<1.1\right)
\end{aligned}
$$

The nominal output power curve for the GE 500-KW WECS used in the example study is defined by Equations. $(E-2)$ and $(E-3)$ with $P_{r}=0.5 \mathrm{MW}$. $P_{f}=0.9$, and $v_{\text {in }}, V_{\text {rated }}$ and $v_{\text {out }}$ as listed in Table 1. This curve is illustrated graphically in Figure 6 , or as the equivalent power coefficient curve shown in Figure 7.

Correction for wind direction change, for density, shear, and anemometer errors, and for the effects of gusts are applied to these basic characteristics to define the effective wind speed and actual WECS power output. 
Table 1. Wind Speed Parameters Defining the Operating Curve of the GE $500 \mathrm{KW}$ WECS

$$
\left(P_{Y}=0.5 \mathrm{MW}, P_{\mathrm{F}}=0.9\right)
$$

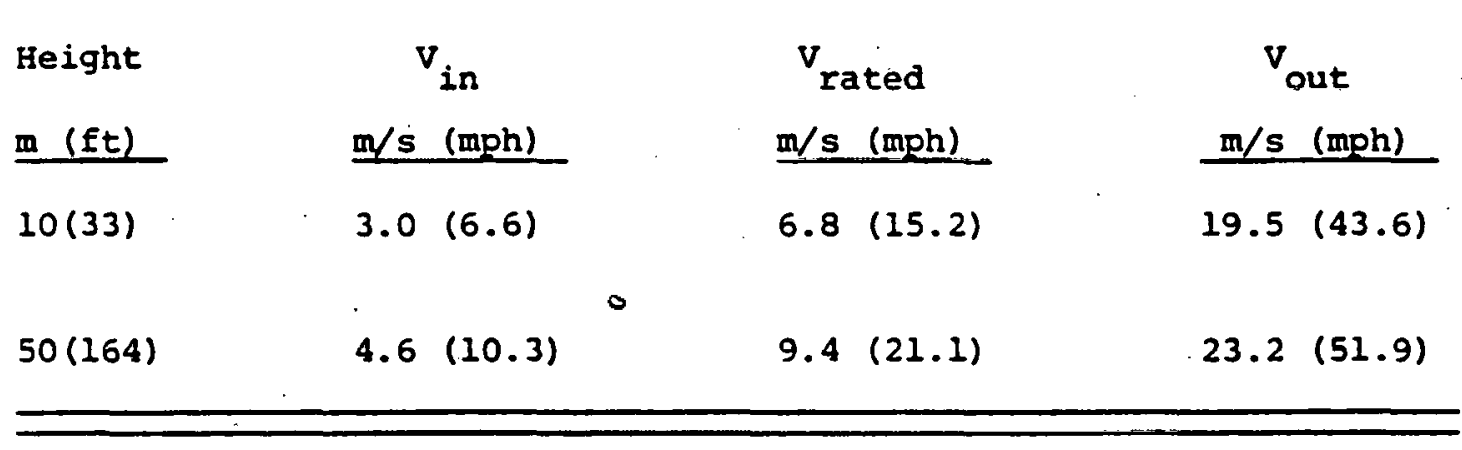


$10 \mathrm{~m}$ (33 ft) Wind Speed

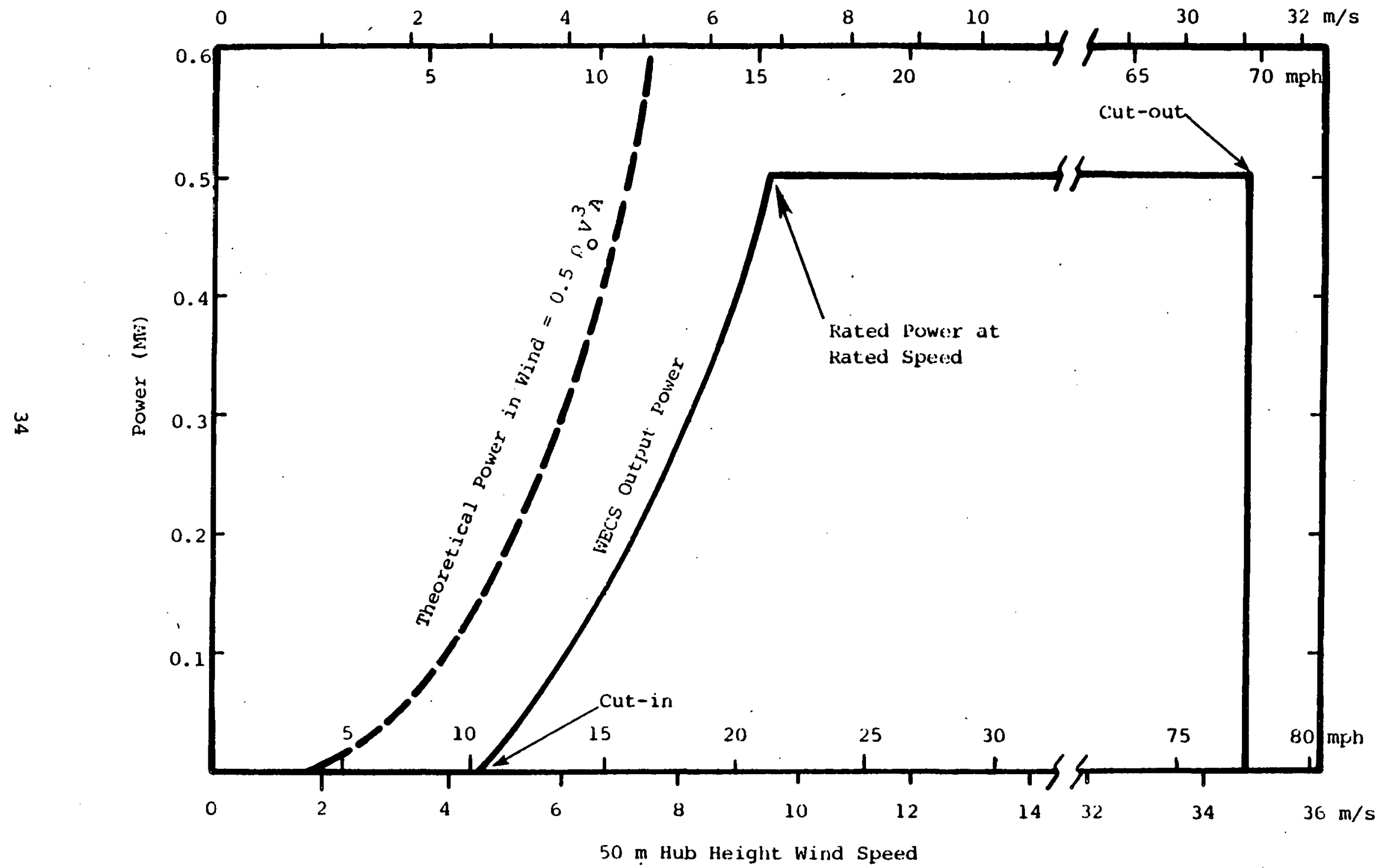

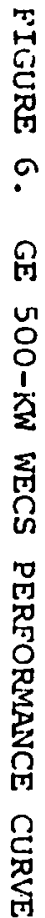

m Hub Height Wind Speed 
$10 \mathrm{~m}(33 \mathrm{ft})$ Wind speed

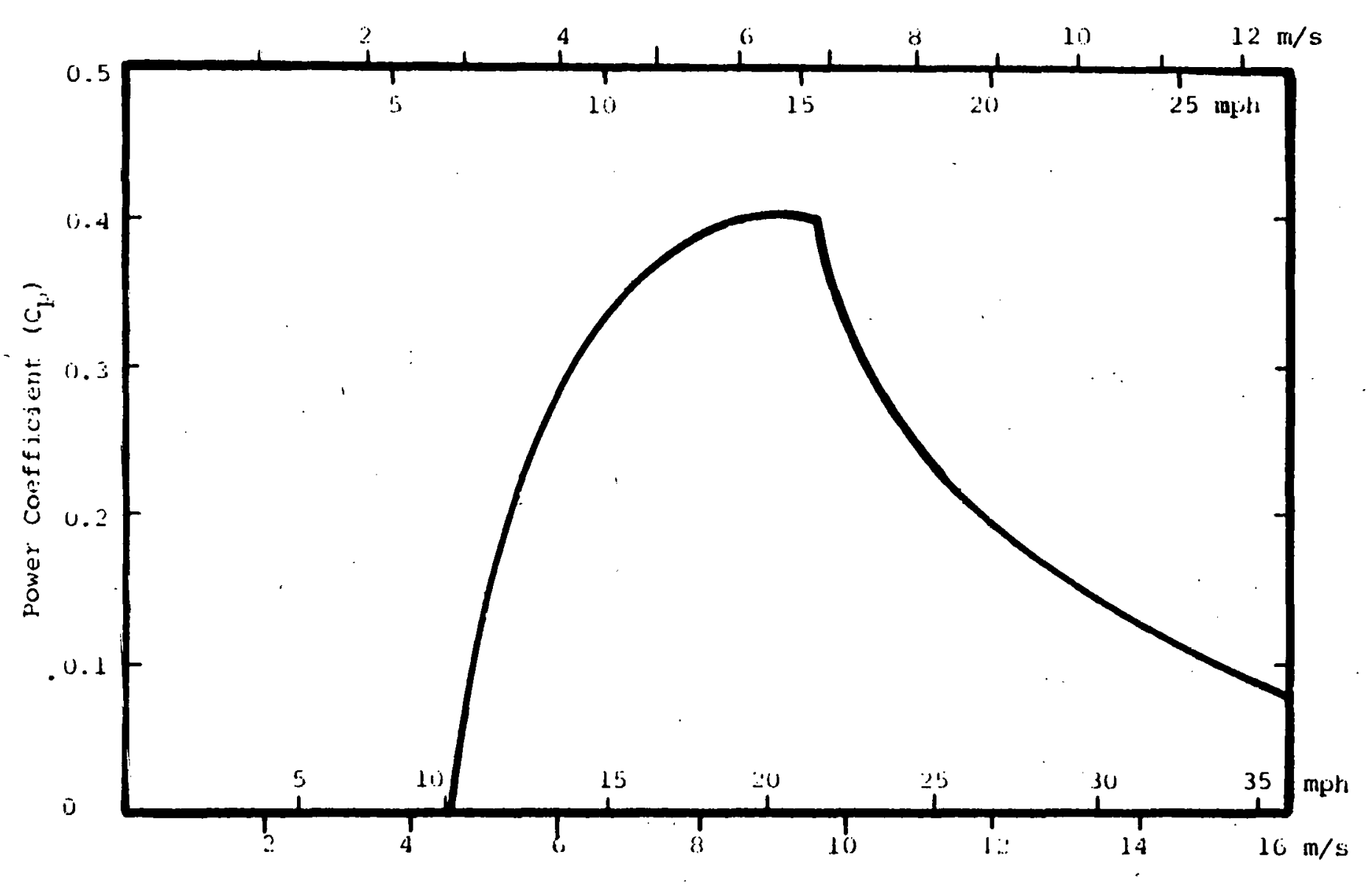

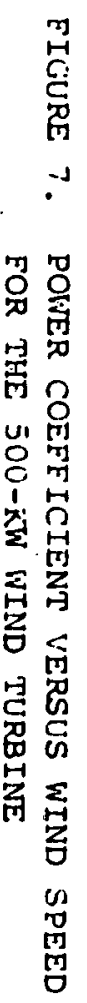

so $\mathrm{m}$ Wind speed 
INOTES $(1.1 .4)$

1. DEW, 31, Appendix F.

2. DEW, 32 (Figure 7): Eldridge 1975).

3. JBF1, Appendix E (Section E.2, Table E-1, Figures E-1 and E-2). 


\subsection{Choice of wind Machines and Sites}

\subsubsection{Selection of WECS}

DeWinkel affirms that the major parameter characterizing a wind machine is the rated power density, defined as:

$$
P_{\text {rd }}=\frac{P_{r}}{A} \quad\left(W / m^{2}\right)
$$

where

$P_{r}$ is the rated power (W)

A is the total swept area of the blades $\left(\mathrm{m}^{2}\right)$

Dewinkel-writes: ${ }^{1}$

Given a certain rated power output or capacity, a large rotor (low-rated power density), will reach its rated capacity at a relatively low wind speed. Such a wind machine with a low rated power density is therefore effective at relatively low wind speeds, but wastes a fraction of the energy in the high winds. Small rotors (high $\mathrm{P}_{\text {d }}$ ) will reach that same capacity at a relatively high wind speed and are therefore better in a high wind regime.

The rated power densities of machines selected for DeWinkel's study are presented in Table $2 .{ }^{2}$ specific energy outputs $E_{S}$ of the three machines as a function of annual average wind speed are plotted in Figure 8 . for the twelve weather stations in and around the state of Wisconsin. 3 Dewinkel uses hub heights of 20,30 , and $60 \mathrm{~m}$ in his calculations. Wind speed observations made at $7 \mathrm{~m}$ are adjusted to these heights using the 1/7-power law.

The JBF study cites the design speed as "a particularly Important factor for WECS, because it is the average wind speed of a site or region for which a given WECS design has been optimized." 4 For this reason, design speed is the chosen criteria for selecting wECs. If the wind speeds 
Table 2. Characteristics of Three Selected Wind Machines (DeWinkel's study)

\begin{tabular}{|c|c|c|c|}
\hline & \multicolumn{3}{|c|}{ Rated power density $\left(\mathrm{W} / \mathrm{m}^{2}\right)$} \\
\hline . & 90 & 220 & 305 \\
\hline Cut-in wind speed $(\mathrm{m} / \mathrm{s})$ & 3.6 & 4.2 & 5.1 \\
\hline Rated wind speed (m/s) & 8.0 & 10.4 & 11.7 \\
\hline Cut-out wind speed (m/s) & 26 & 26 & 26 \\
\hline Example of wind machine & $\begin{array}{c}\text { NASA/DOE } \\
100 \mathrm{~kW}\end{array}$ & $\begin{array}{l}\text { Boeing } \\
1125 \mathrm{~kW}\end{array}$ & $\begin{array}{l}\text { Kaman } \\
500 \mathrm{~kW}\end{array}$ \\
\hline
\end{tabular}


FIGURE 8. SPECIFIC ENERGY OUTPUT AS A FUNCTION OF THE ANNUAL AVERAGE WIND SPEED AND RATED POWER DENSITY OF THE WIND MACHINES.

(CALCULATED FOR THE TWELVE AIRPORT SITES (BLACK DOTS). DATA AVERAGED OVER SIX YEARS.) (DeWinkel)

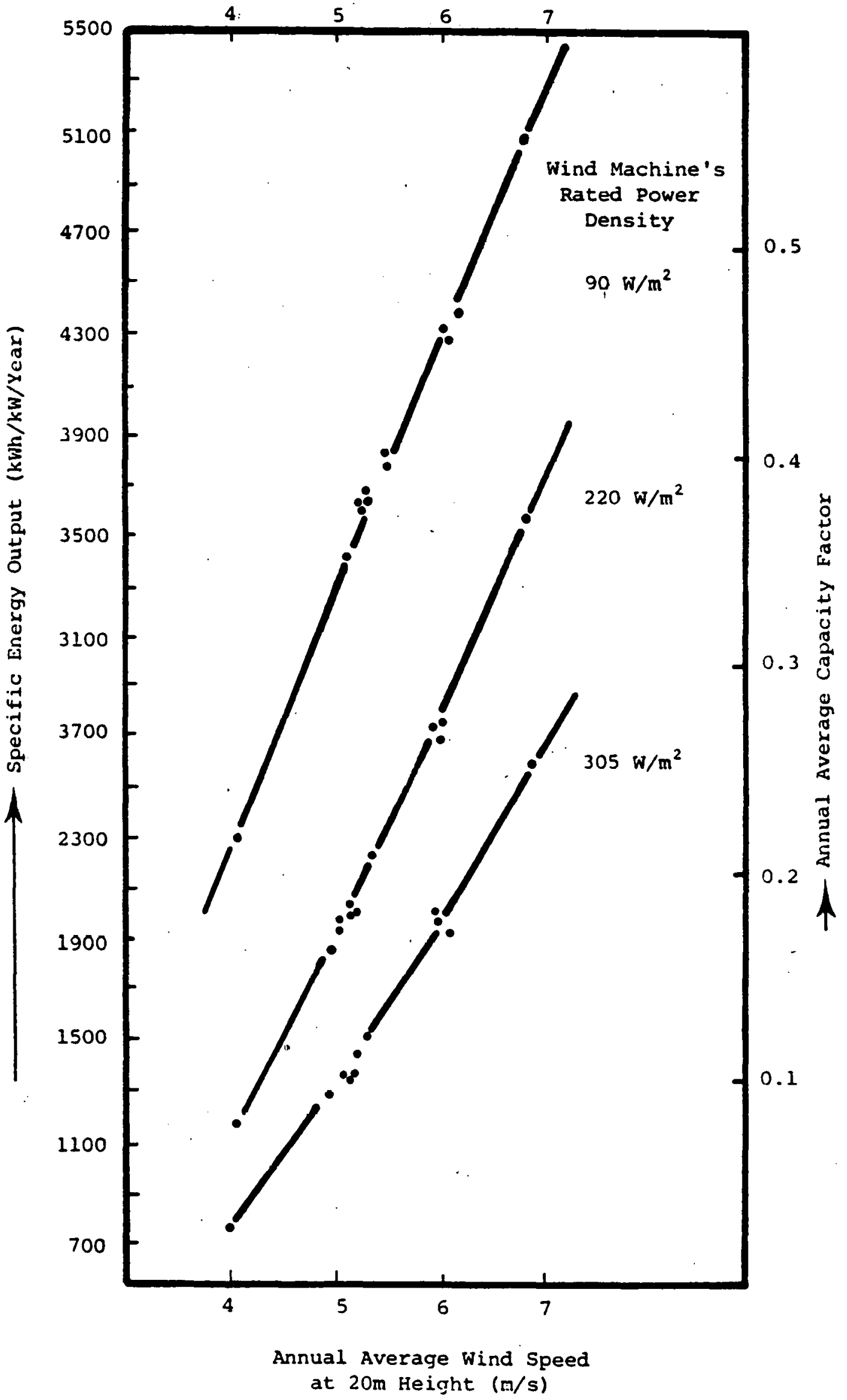


at the prospective WECS sites in a region are fairly uniform, then it becomes advantageous to select only one WECS design. Uniform maintenance procedures and price breaks for quantity purchases could result in savings in capital costs and $O \& M$. Interfacing costs would also decrease.

The General Electric $500 \mathrm{KW}$ WECS was selected as the baseline unit for the JBF study. Its design speed $(5.36 \mathrm{~m} / \mathrm{s}$ at $10 \mathrm{~m} \mathrm{ref}$. height) is only slightly more than the overall average wind speed $(5 \mathrm{~m} / \mathrm{s})$ of the NEGEA service region. The characteristics of this unit are presented in Figure 9. 5 The basic analysis conducted using the GE $500 \mathrm{KW}$ WECS was extended to a family of other wECs designs, varying in rated wind speed from $5.42 \mathrm{~m} / \mathrm{s}$ to $14.42 \mathrm{~m} / \mathrm{s}$. The rated wind speeds of these ten hypothetical machines are related to the cut-in speeds by a factor of 2.04 , a value suggested by similar ratios seen in four existing machines.

Three wind turbine generator (WTG) designs were considered in the Southwest Research Institute study. Their characteristics are indicated in the following table: ${ }^{6}$

\begin{tabular}{|c|c|c|c|c|c|c|c|}
\hline \multirow[b]{2}{*}{ Name } & \multirow{2}{*}{$\begin{array}{l}\text { Rated } \\
\text { Power } \\
\text { (MW) } \\
\end{array}$} & \multirow{2}{*}{$\begin{array}{c}\text { Rated } \\
\text { Wind Speed } \\
(\mathrm{m} / \mathrm{s}) \\
\end{array}$} & \multirow{2}{*}{$\begin{array}{c}\text { Rotor* } \\
\text { Diameter } \\
\text { (m) } \\
\end{array}$} & \multicolumn{4}{|c|}{ Hub Height (m) } \\
\hline & & & & 30 & 45 & 60 & 75 \\
\hline WTG-8 & 1 & 8 & 111.4 & & & $\mathrm{x}$ & $x$ \\
\hline WTG-10 & 1 & 10 & 79.7 & & $x$ & $x$ & $x$ \\
\hline WTG-13 & 1 & 13 & 53.8 & $\mathrm{x}$ & $x$ & $\mathrm{x}$ & $\mathrm{x}$ \\
\hline
\end{tabular}

*Calculated from the formula

$$
D=79.7 \sqrt{\frac{\mathrm{PR} / \mathrm{K} \text { ilowatts }}{(\text { UR/meters per second })^{3}} \text { meters }}
$$

where

$$
\begin{aligned}
& \mathrm{PR}=\text { rated power }(\mathrm{KW}) \\
& \mathrm{UR}=\text { rated windspeed }(\mathrm{m} / \mathrm{s})
\end{aligned}
$$

Their performance curves are given in Figure $10 .^{7}$ 


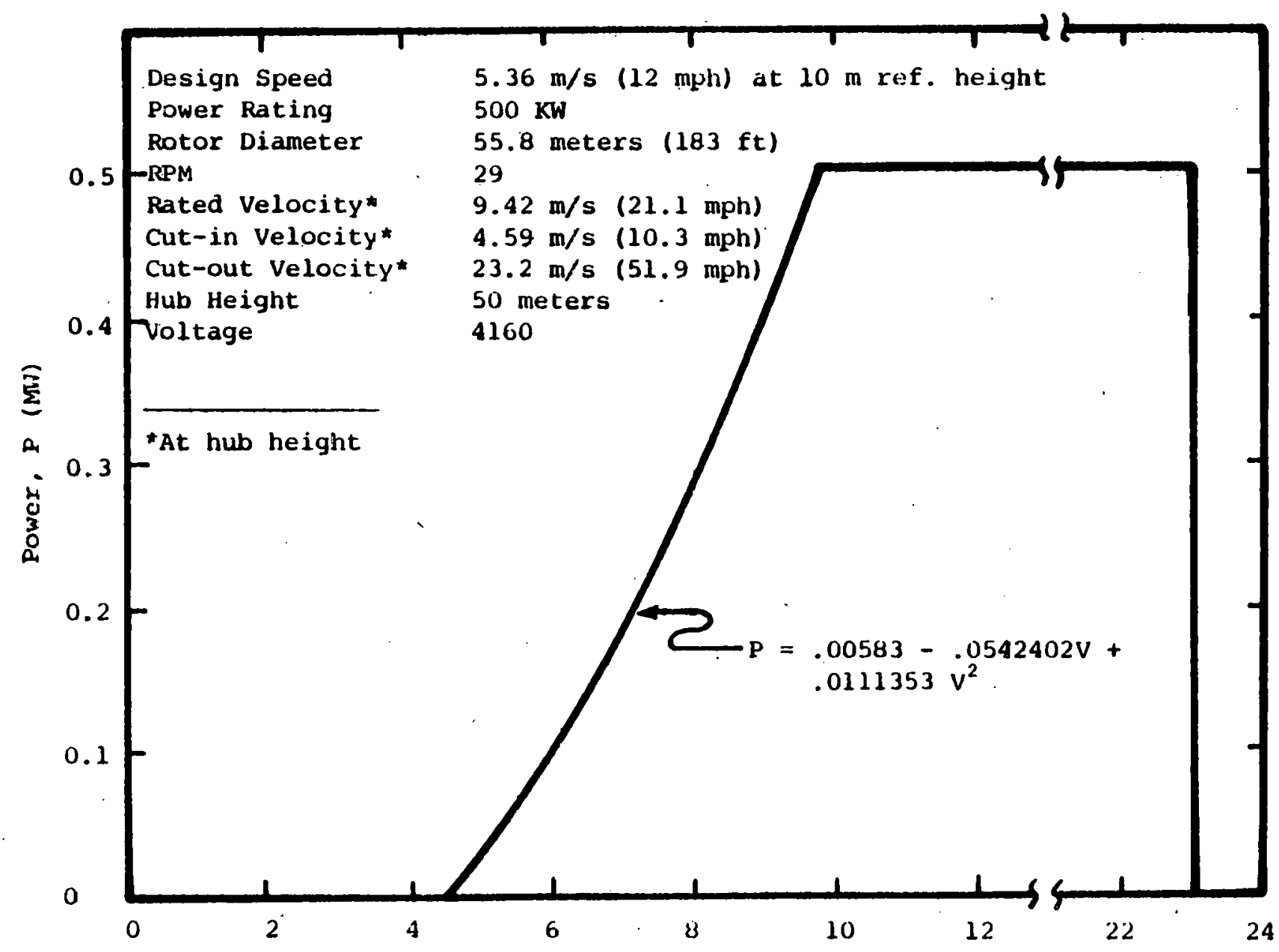

Wind Speed, $V$, at llub Height $(\mathrm{m} / \mathrm{s})$ 


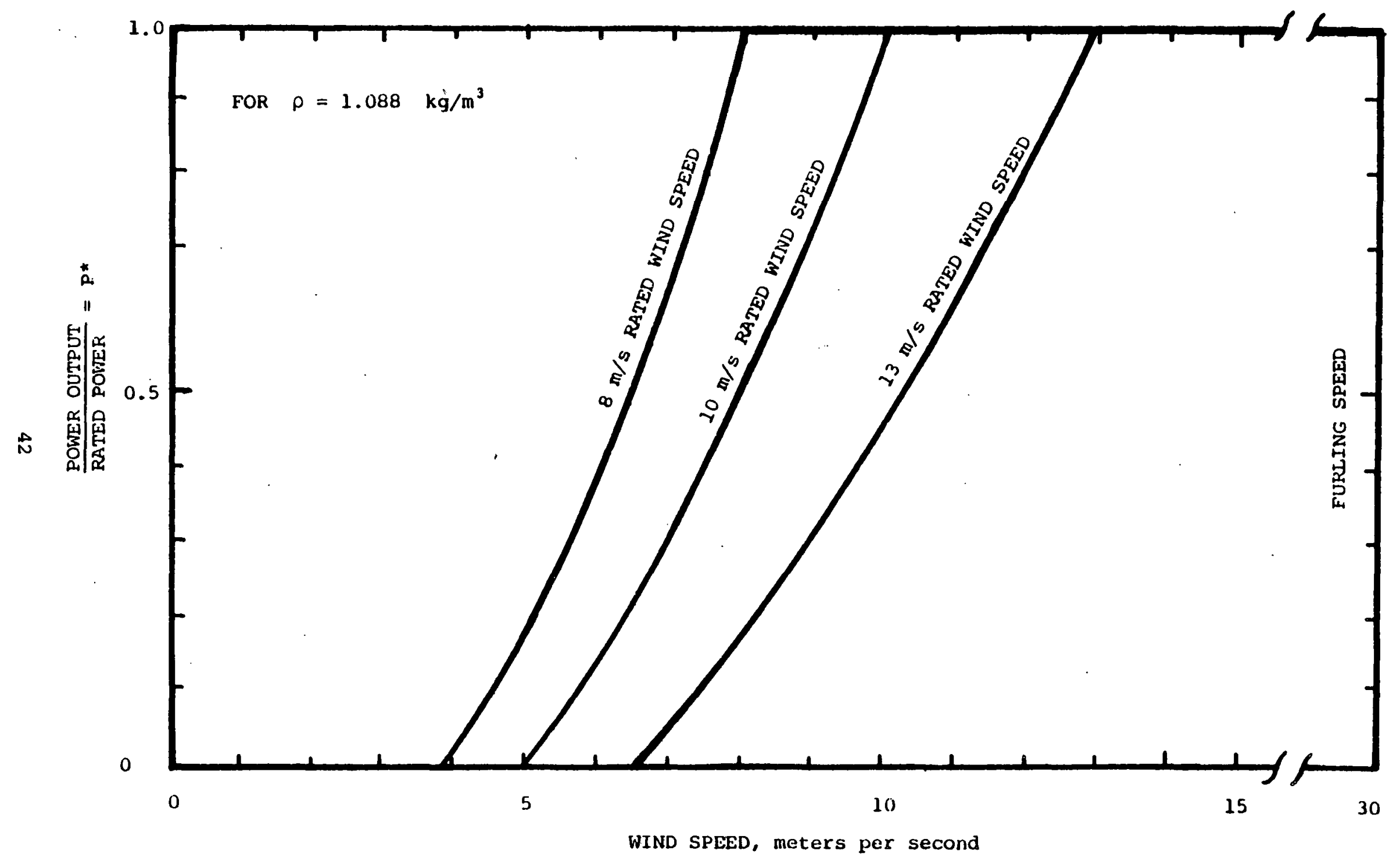

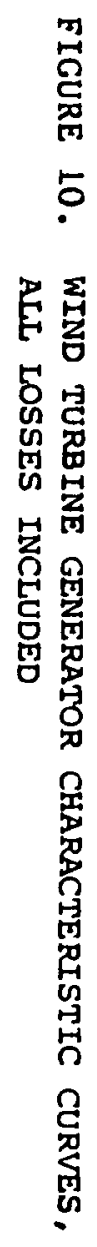

WIND SPEED, meters per second 
NOTES (1.1.5)

1. DEW, 35 .

2. DEW, 42 (Table 4).

3. DEW, 44 (Figure 12).

4. JBF1, 3-9.

5. JBF1, 3-12 (Figure 3-3).

6. SWRI, 28 .

7. SWRI, 29 (Figure 11). 


\subsection{Choice of wind Machines and Sites}

\subsubsection{WECS Array Power Performance}

To define the power performance of a typical WECS array, the JBF study developed a methodology for simulating the performance of the array using data from a single representative site. The calculation of array average output power is based on a Weibull function characterization of wind speed distribution and a linear regression function for WECS unit power output. The distribution of array wind speeds $v_{n}$ for an $n$ site array is given by: ${ }^{1}$

$$
p\left(v_{n}\right)=\left(k_{n} / c_{n}\right)\left(v_{n} / c_{n}\right)^{k_{n}-1} \exp \left[-\left(v_{n} / c_{n}\right)^{k}\right]
$$

where

$$
\begin{aligned}
& k_{n}=\left(\sigma_{n} / \bar{v}_{n}\right)^{-0.086} \quad \text { [Weibul] shape parameter] } \\
& c_{n}=v_{n} / \Gamma\left(1+1 / k_{n}\right) \quad \text { [Weibull scale factor] } \\
& Y=\text { empirical adjustment factor }[\tilde{=} 1.02-1.03] \\
& \Gamma \text { is the usual garma function }
\end{aligned}
$$

The shape parameter expression is an approximation to the theoretical relation between $k$ and $\sigma / \vec{v}$

$$
(\sigma / \bar{v})^{2}=\left[\Gamma(1+2 / k) / \Gamma^{2}(1+1 / k)\right]-1
$$

The array power $P\left(V_{n}\right)$ per WECS unit in the array was assuned to be a linear function of the array wind speed:

$$
P\left(V_{n}\right) / P=a+b\left(V_{n} / V_{r}\right)
$$

where

$$
\begin{aligned}
& P_{r} \text { is the rated power } \\
& V_{n} \text { is the array wind speed (at hub height) } \\
& V_{Y} \text { is the rated wind speed of the wEcs units in the array }
\end{aligned}
$$


Based on the above linear regression and Weibull distribution functions, the array average output power $\bar{P}$ is

$$
\bar{P}_{n} / P_{r}=\int_{0}^{\infty}\left[a+b\left(\bar{v}_{n} / v_{r}\right)\right] p\left(v_{n}\right) d v_{n}
$$

This equation can be interpreted as the capacity factor for the WECS array. It should be noted that an array simulated using a single representative site has an average wind speed equal to that of the site and a power output equal to that of the site, but that the probability distributions of wind speed and power output are affected by the array simulation assumed. The array has less variability than the individual site. This effect is illustrated by a comparison of array and single-site probability distributions for the Falmouth site (Figure 11 ). ${ }^{2}$ A 708 spatial cross correlation of wind speeds between sites $(p=0.7)$ was assumed for the array. 
Cunulative Probability (b) of Output Power $\geq p$

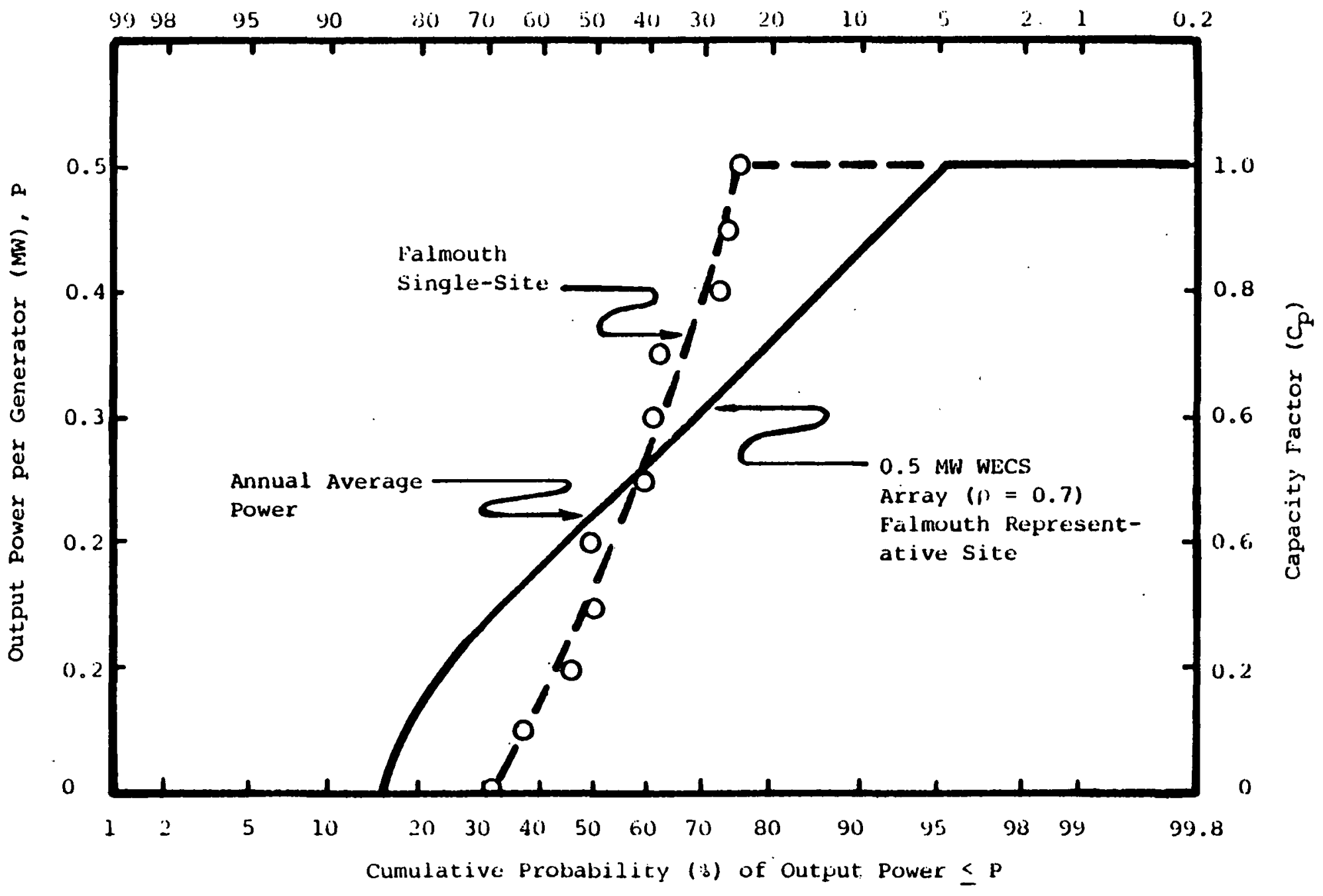




\section{NOTES $(1.1 .6)$}

1. JBE1, Appendix F.

2. JBF1, 3-16 (Figure 3-5). 


\subsection{Choice of Wind Machines and Sites}

\subsubsection{Siting and Interface Requirements}

The generic process of utility would follow in selecting weCs sites and an application of this process to the case of a specific utility are described in volume I, Chapter 4 of the JBF study. The tasks included in the generic process are outlined below along with comments.

(1) Identify preferred geographic areas.

Evaluation of a region is based on the available wind resource. A simple rule applies: The higher the average wind speed, the more preferable the area.

(2) Define WECS land requirements/restrictions.

For the puxposes of the study, it was assumed that the utility would purchase area approximately equal to the tower footprint and would obtain easement on additional area to a radius of one WECS tower-plus-blade distance.

Site location restrictions include consideration of the following:

- RF interference

- Noise

- Airport Clear Zones

- Government Land

- Aerodynamic Interference

- Structural Soil Properties

- Seismic Activity

- Migrating Birds 
In order to minimize mutual aerodynamic interference between WECS units, a minimum spacing of ten rotor diameters was assumed.

(3) Eliminate technically unacceptable sites.

Topographic maps obtainable from the U.S. Department of the Interior Geological Survey may be used to identify prospective areas for WECS installations. Of the land that is identified as acceptable, a certain percentage (40\% by NEGEA experience) will not be attainable from the present owners.

(4) Evaluate social, legal, and environmental factors.

Certification to construct power-generating facilities must be obtained from a number of local, state, and federal agencies. Environmental assessment and/or impact statements must be submitted to regulatory agencies. The aesthetic impact on the local area may be a major concern with wECS.

\section{(5) Define interface requirements.}

WECS power output voltage would have to be stepped up before it could be introduced to the grid. This could be done on a unit-by-unit basis by means of pad-mounted or pole-top transformers, or several WECS could be serviced by a sub-station. The "effective capacity" of lines to which wECS units are connected need to be considered. If WECS output power exceeds a line's effective capacity (the sum of the line power rating and the minimum load on the line), then either the output must be split among more than one line or connected to a line with a higher effective capacity. The latter alternative may necessitate additional step-up substations. 
(6) Define land and interface costs.

The land costs, ancillary site costs, and interface costs estimated for the JBF study are presented in Table 3.1 The total cost of $\$ 43,300$ per site translates to about $\$ 87$ per $\mathrm{KW}$ for the $500 \mathrm{~kW}$ wECS (1976 dollars).

(7) Select actual WECS sites.

In this step specific WECS sites would be identified. The actual wind resource at each site may then be confirmed by on-site measurement. If it differs significantly from what is expected, the WECS analysis would have to be re-done based on the actual resource available.

In a section entitled "Windpower Utilization Potential", the Southwest Research Institute study evaluates in detail three modes of distributing WECS or WECS arrays in the SWPS service region: ${ }^{2}$

- Uniform deployment (units spaced 20 to 80 turbine diameters apart over entire service region)

- Wind farm arrays (clusters of units with 5 or 10 diameter spacing)

- Transmission line arrays (units spaced every $1 \mathrm{~km}$ along lines)

The SWPS service area is divided into five parts, named wind farm regions (WFR), such that each WFR is of similar size and each contains a major power generation center and hence convergence center for transmission lines. 
Table 3.

WECS SITING AND INTERFACE COST SUMMARY

(\$/Site in 1976 Dollars)

$\begin{array}{lr}\text { Transmission Lines } & 12,900 \\ \text { Local Transformers } & 2,200 \\ \text { Substation } & 2,700 \\ \text { Miscellaneous } & \\ \text { Title Search Fees } & 2,500 \\ \text { Survey Plot Plan } & 5,500 \\ \text { Negotiating Agent } & 500 \\ \text { Access Road } & 1,500 \\ \text { Clearing Property } & 2,500 \\ \text { Environmental Impact Statement } & 1,500 \\ \text { Wind Measurements (593 sites) } & 4,200\end{array}$

Land:

Easement

Purchase

Total

Total Cost Per Site
6,656

684

$\$ 43,300$ 
NOTES $(1.1 .7)$

1. JBFl, 4-22 (Table 4-9).

2. SWRI, 47-71. 


\subsubsection{Wind Characteristics in Indiana}

Wind speed data was obtained for six airport weather stations as well as for four meteorological stations at utility generating plants. Table 4 presents the source, site, observation interval, and anemometer height for the data obtained for this study. Further information on the stations is included in Tables 5 and 6 . Locations of the sites are shown in Figure 12.

The NCC data contains very few missing records, most of these occurring during the initial two years, 1948 and 1949. For the purpose of the study, hourly wind data was drawn from the five year period 1973-77 and organized into monthly data files. All six NCC sites are represented: Indianapolis, Terre Haute, Fort Wayne, South Bend, Evansville, and Louisville. Annual 5-year averages of wind speed at three different heights are reported in Table 7. These values were obtained using the JBF computer programs SERIES and WINDS.

The PSI meteorological data was not used for wECS evaluation because a complete five year time series was not available and because too many data points were either missing or invalid.

The seasonal and hourly variation of wind speed for Indianapolis at a height of 30 meters is displayed in Table 8 and Figures 13 and 14 . Note that the highest average wind speeds occur in late winter/early spring (Phase $3,2 / 27$ through $3 / 26$ ) and in the late afternoon hours ( 3 to $40^{\prime}$ clock). Low winds occur at night and in late summer (Phase 9, 8/14 through 9/10). 
Table 4. WIND DATA OBTAINED FROM THE NATIONAL CLIMATIC CENTER (NCC) AND FROM PUBLIC SERVICE INDIANA (PSI), 1948-1978.

\begin{tabular}{|c|c|c|c|c|}
\hline \multirow{2}{*}{$\begin{array}{l}\text { Site } \\
\text { Code }\end{array}$} & \multirow[t]{2}{*}{ Site } & \multicolumn{2}{|c|}{$\begin{array}{l}\text { Years for Data with } \\
\text { Indicated Observation Interval }\end{array}$} & \multirow{2}{*}{$\begin{array}{l}\text { Anemometer } \\
\text { Height } \\
\text { (m) }\end{array}$} \\
\hline & & Hourly & 3-Hourly & \\
\hline \multicolumn{3}{|c|}{ NCC Data Obtained from IJCC: } & - & \\
\hline EW & Fort Wayne & $48-64,73-77$ & $65-72,78$ & varies \\
\hline SB & South Bend & $48-64,73-77$ & $65-72,78$ & $"$ \\
\hline EV & Evansville & $48-64,70-77$ & $65-69,78$ & $"$ \\
\hline IP & Indianapolis & $48-64,72-78$ & $65-71$ & $"$ \\
\hline LV & Louisville & $48-64,72-76$ & $65-71$ & $"$ \\
\hline \multicolumn{3}{|c|}{ NCC Data Supplied by PSI: } & & \\
\hline IP & Indianapolis & $73-77$ & & 6.1 \\
\hline TH & Terre Haute & $73-77$ & & 6.1 \\
\hline EV & Evansville & $73-77$ & & 6.1 \\
\hline LV & Louisville & $73-77$ & & 6.1 \\
\hline \multicolumn{3}{|c|}{ PSI Meteorological Data: } & & \\
\hline Wn * & Wabash River & $77-78$ & & 10,60 \\
\hline $\mathrm{Cn}$ & Cayuga & $77-78$ & & 10,60 \\
\hline En & Edwardsport & $77-78$ & & 10 \\
\hline Gn & Gibson & $77-78$ & & 10,60 \\
\hline
\end{tabular}

${ }^{*} n=1$ or 6 , depending on anemometer height $(10 \mathrm{~m}$ or $60 \mathrm{~m})$. There is no $60 \mathrm{~m}$ data available for Edwardsport. 
Table 5. SITE ANEMOMETER HISTORIES FOR HCC PRIMARY STATIONS

\begin{tabular}{|c|c|c|c|c|c|c|c|c|}
\hline \multirow{2}{*}{$\begin{array}{l}\text { NCC } \\
\text { Station } \\
\text { No. }\end{array}$} & \multirow[b]{2}{*}{$\begin{array}{l}\text { Station } \\
\text { Name }\end{array}$} & \multirow[b]{2}{*}{$\begin{array}{l}\text { Occupied } \\
\text { From - To }\end{array}$} & \multirow[b]{2}{*}{$\begin{array}{l}\text { Latitude } \\
\text { North }\end{array}$} & \multirow[b]{2}{*}{$\begin{array}{l}\text { Longitude } \\
\text { West }\end{array}$} & \multicolumn{4}{|c|}{ Elevation Above } \\
\hline & & & & & $\begin{array}{c}\text { Sea } ~ \\
m\end{array}$ & $\begin{array}{l}\text { vel } \\
\text { ft }\end{array}$ & $\begin{array}{l}\text { Grou } \\
\mathbf{m}\end{array}$ & $\mathrm{ft}$ \\
\hline 1. 14827 & $\begin{array}{l}\text { Fort Wayne, IN } \\
\text { Baer Field }\end{array}$ & $\begin{array}{l}12 / 16 / 46-11 / 20 / 48 \\
11 / 20 / 48-03 / 13 / 53 \\
03 / 13 / 53-09 / 16 / 57 \\
09 / 16 / 57-09 / 25 / 61 \\
09 / 25 / 61 \text { - Present }\end{array}$ & $\begin{array}{l}41^{\circ} 00^{\prime} \\
41^{\circ} 00^{\prime} \\
41^{\circ} 00^{\prime} \\
41^{\circ} 00^{\prime} \\
41^{\circ} 00^{\prime}\end{array}$ & $\begin{array}{l}85^{\circ} 13^{\prime} \\
85^{\circ} 13^{\prime} \\
85^{\circ} 12^{\prime} \\
85^{\circ} 12^{\prime} \\
85^{\circ} 12^{\prime}\end{array}$ & $\begin{array}{l}244.1 \\
244.1 \\
244.1 \\
244.1 \\
241.1\end{array}$ & $\begin{array}{l}801 \\
801 \\
801 \\
801 \\
791\end{array}$ & $\begin{array}{r}10.4 \\
9.1 \\
18.9 \\
20.7 \\
6.1\end{array}$ & $\begin{array}{l}34 \\
30 \\
62 \\
68 \\
20\end{array}$ \\
\hline 2. 14848 & $\begin{array}{l}\text { South Bend, IM } \\
\text { Michiana } \\
\text { Regional Airport }\end{array}$ & $\begin{array}{l}02 / 10 / 42-11 / 10 / 49 \\
11 / 10 / 49-03 / 05 / 63 \\
03 / 05 / 63-08 / 01 / 63 \\
08 / 01 / 63 \text { - Present }\end{array}$ & $\begin{array}{l}41^{\circ} 42^{\prime} \\
41^{\circ} 42^{\prime} \\
41^{\circ} 42^{\prime} \\
41^{\circ} 42^{\prime}\end{array}$ & $\begin{array}{l}86^{\circ} 19^{\circ} \\
86^{\circ} 19^{\circ} \\
86^{\circ} 19^{\circ} \\
86^{\circ} 19^{\prime}\end{array}$ & $\begin{array}{l}233.6 \\
234.1 \\
234.1 \\
235.6\end{array}$ & $\begin{array}{l}766 \\
768 \\
768 \\
773\end{array}$ & $\begin{array}{r}7.3 \\
17.7 \\
6.4 \\
6.4\end{array}$ & $\begin{array}{l}24 \\
58 \\
21 \\
21\end{array}$ \\
\hline 3. 93817 & $\begin{array}{l}\text { Evansville, IH } \\
\text { Dress } \\
\text { Regional Airport }\end{array}$ & $\begin{array}{l}08 / 31 / 40-02 / 21 / 51 \\
02 / 22 / 51-09 / 23 / 61 \\
09 / 23 / 61 \text { - Present }\end{array}$ & $\begin{array}{l}38^{\circ} 02^{\circ} \\
38^{\circ} 03^{\prime} \\
38^{\circ} 03^{\prime}\end{array}$ & $\begin{array}{l}87^{\circ} 32^{\prime} \\
87^{\circ} 32^{\prime} \\
87^{\circ} 32^{\prime}\end{array}$ & $\begin{array}{l}117.3 \\
116.7 \\
116.1\end{array}$ & $\begin{array}{l}385 \\
383 \\
381\end{array}$ & $\begin{array}{r}12.2 \\
19.5 \\
6.1\end{array}$ & $\begin{array}{l}40 \\
64 \\
20\end{array}$ \\
\hline 4. 93819 & $\begin{array}{l}\text { Indianapolis, IN } \\
\text { International } \\
\text { Airport }\end{array}$ & $\begin{array}{l}05 / 01 / 41-11 / 09 / 59 \\
11 / 09 / 59-12 / 21 / 62 \\
12 / 21 / 62 \text { - Present }\end{array}$ & $\begin{array}{l}39^{\circ} 44^{\circ} \\
39^{\circ} 44^{\prime} \\
39^{\circ} 44^{\prime}\end{array}$ & $\begin{array}{l}86^{\circ} 16^{\prime} \\
86^{\circ} 16^{\prime} \\
86^{\circ} 16^{\prime}\end{array}$ & $\begin{array}{l}241.7 \\
241.7 \\
241.4\end{array}$ & $\begin{array}{l}793 \\
793 \\
792\end{array}$ & $\begin{array}{r}16.5 \\
-19.5 \\
6.1 \\
6.1\end{array}$ & $\begin{array}{r}54 \\
-64 \\
20 \\
20\end{array}$ \\
\hline 5. 93821 & $\begin{array}{l}\text { Louisville, } \mathrm{KY} \\
\text { Standiford } \\
\text { Airport }\end{array}$ & $\begin{array}{l}11 / 15 / 47-09 / 19 / 50 \\
09 / 19 / 50-05 / 07 / 60 \\
05 / 07 / 60-06 / 01 / 60 \\
06 / 01 / 60 \text { - Present }\end{array}$ & $\begin{array}{l}38^{\circ} 11^{\prime} \\
38^{\circ} 11^{\prime} \\
38^{\circ} 11^{\prime} \\
38^{\circ} 11^{\prime}\end{array}$ & $\begin{array}{l}85^{\circ} 44^{\prime} \\
85^{\circ} 44^{\prime} \\
85^{\circ} 44^{\prime} \\
85^{\circ} 44^{\prime}\end{array}$ & $\begin{array}{l}147.8 \\
144.5 \\
144.5 \\
145.4\end{array}$ & $\begin{array}{l}485 \\
474 \\
474 \\
477\end{array}$ & $\begin{array}{r}18.0 \\
21.6 \\
6.1 \\
6.1\end{array}$ & $\begin{array}{l}59 \\
71 \\
20 \\
20\end{array}$ \\
\hline
\end{tabular}


Table 6. METEOROLOGICAL STATION COORDINATES (PUBLIC SERVICE INDIANA)

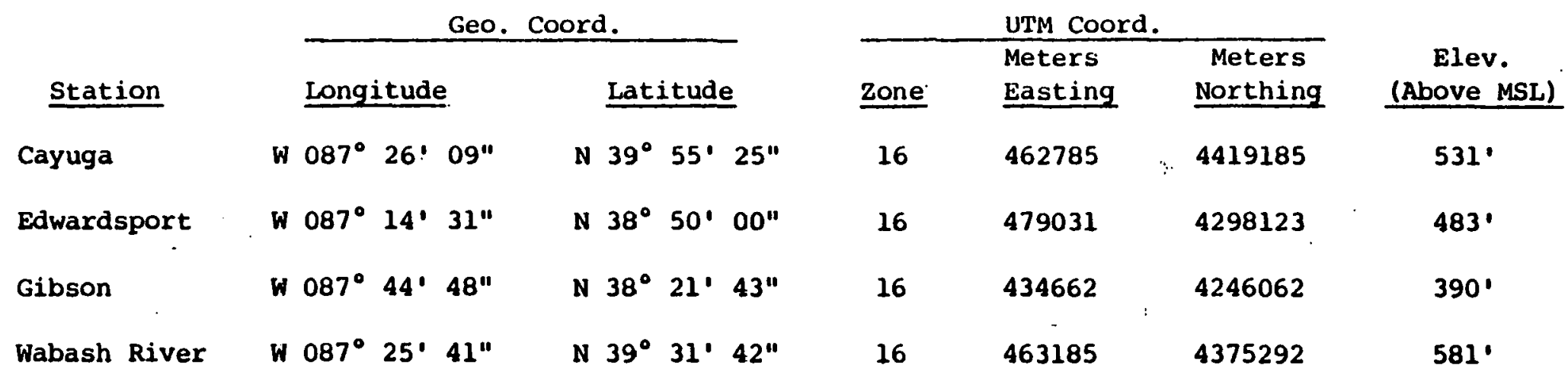


FICURE 12. WIND MEASURING SITES IN AND AROUND THE STATE OE INDIANA.

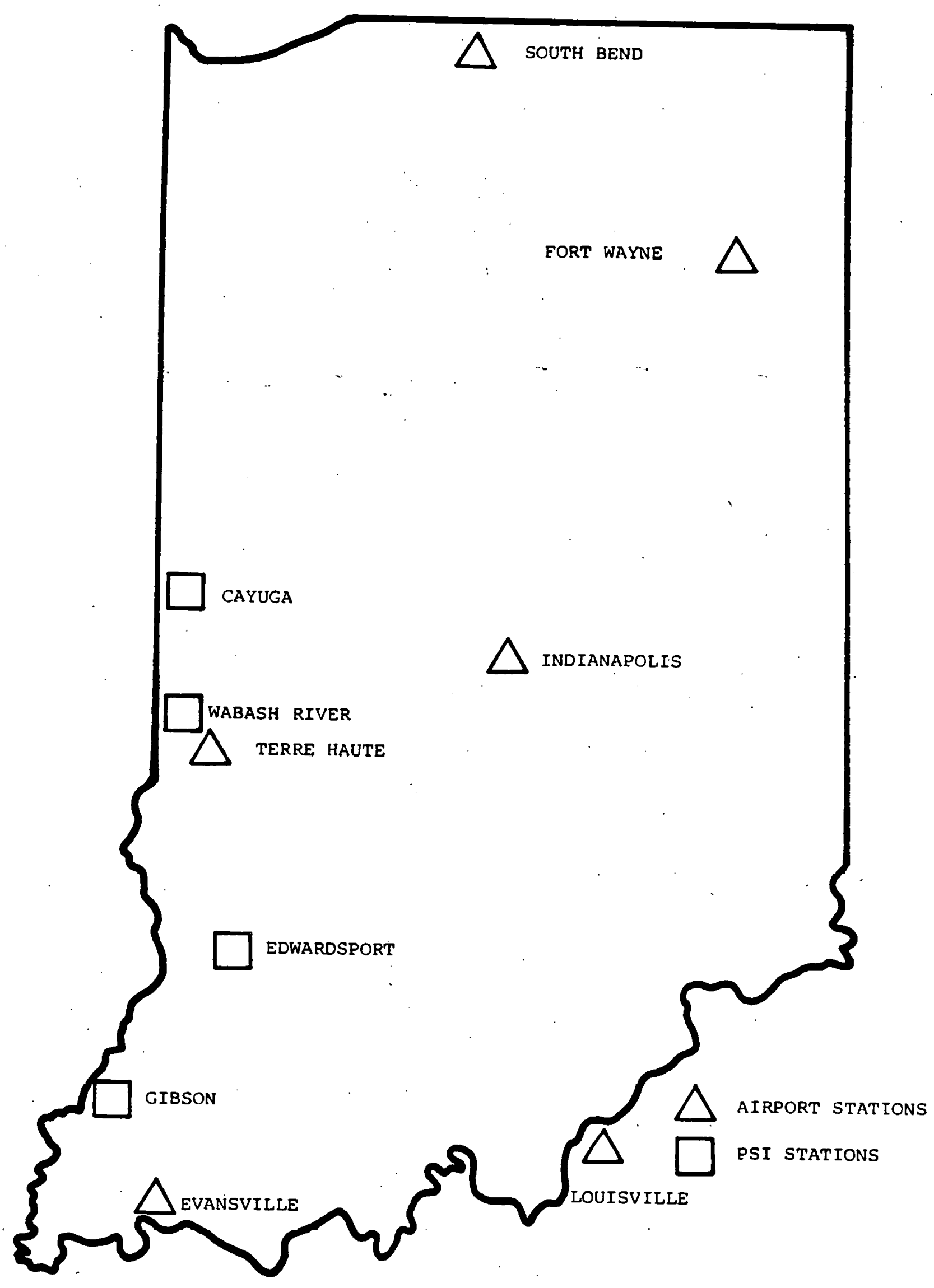


Table 7. ANNUAL 5-YEAR AVERAGE WIND SPEED AND STANDARD DEVIATION FOR LOCATIONS IN AND AROUND THE STATE OF INDIANA. (Wind speed observations, 1973-77, made at height of approximately 6 meters. $v=$ wind speed $(\mathrm{m} / \mathrm{s}), \sigma=$ standard deviation of wind speed $(m / s)$.

\begin{tabular}{|c|c|c|c|c|c|c|}
\hline \multirow{2}{*}{$\begin{array}{l}\text { Site } \\
\text { Code }\end{array}$} & \multirow{2}{*}{\multicolumn{2}{|c|}{ site }} & \multicolumn{3}{|c|}{$\begin{array}{l}\text { Wind Speed } v \text { (m/s) at } \\
\text { Height Above Ground (m) }\end{array}$} & \multirow{2}{*}{$\begin{array}{c}\text { Average } \\
\sigma / v\end{array}$} \\
\hline & & & 20 & 25 & 30 & \\
\hline IP & Indianapolis & & 5.41 & 5.69 & 5.93 & 0.32 \\
\hline $\mathrm{TH}$ & Terre Haute & & 4.76 & 5.02 & $5 . .23$ & 0.38 \\
\hline FW & Fort Wayne & & 5.93 & 6.22 & 6.47 & 0.35 \\
\hline SB & South Bend & & 5.67 & 5.95 & 6.19 & 0.36 \\
\hline EV & Evansville & & 4.33 & 4.57 & 4.77 & 0.44 \\
\hline LV & Louisville & & 4.94 & 5.21 & 5.43 & 0.36 \\
\hline & Mean & & 5.17 & 5.44 & 5.67 & \\
\hline
\end{tabular}


Table 8. ANNUAL ARRAY AVERAGE SPEED (m/s) BY PHASE AND HOUR FOR INDIANAPOLIS AT A HEIGHT OF 30 METERS

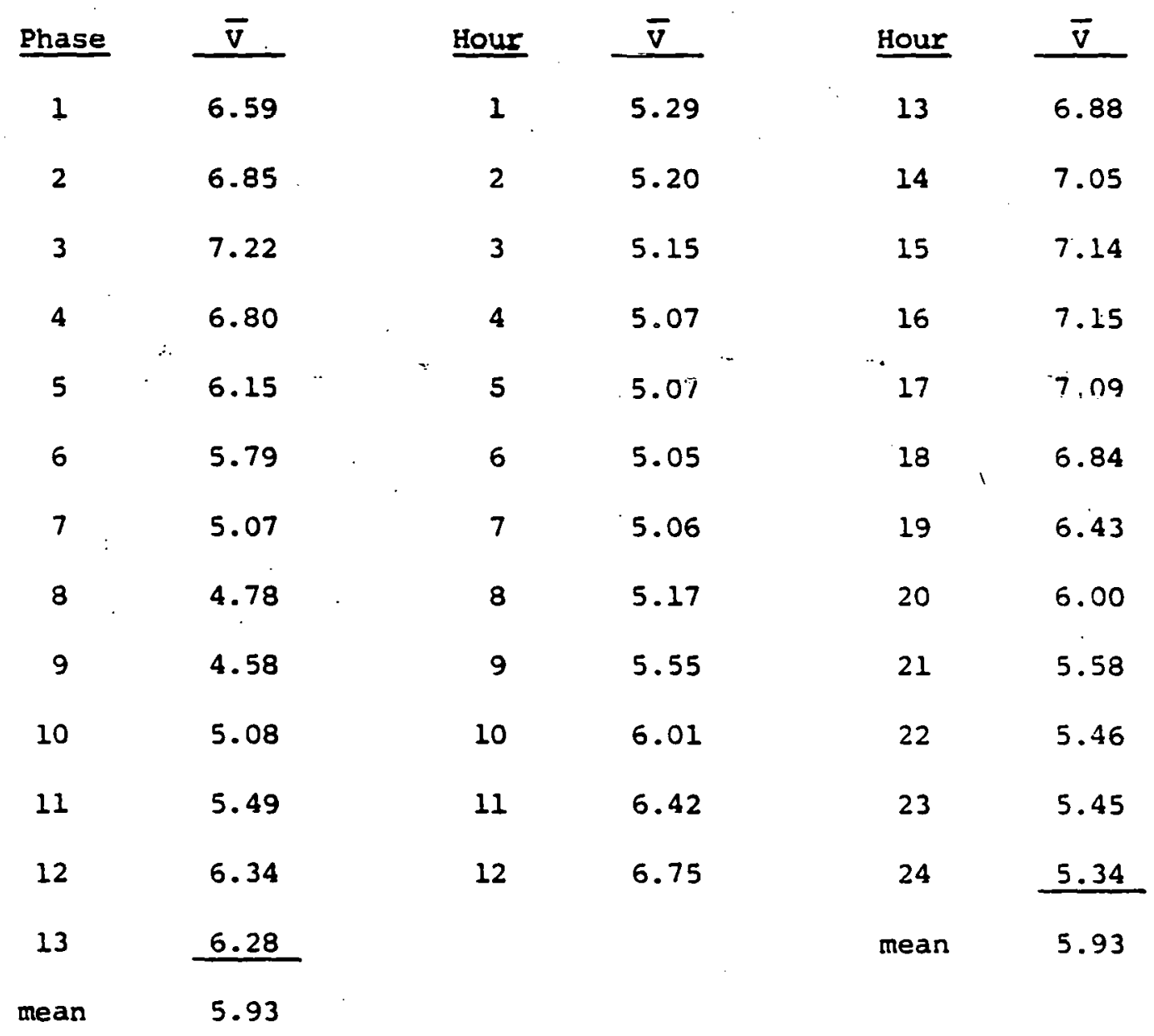




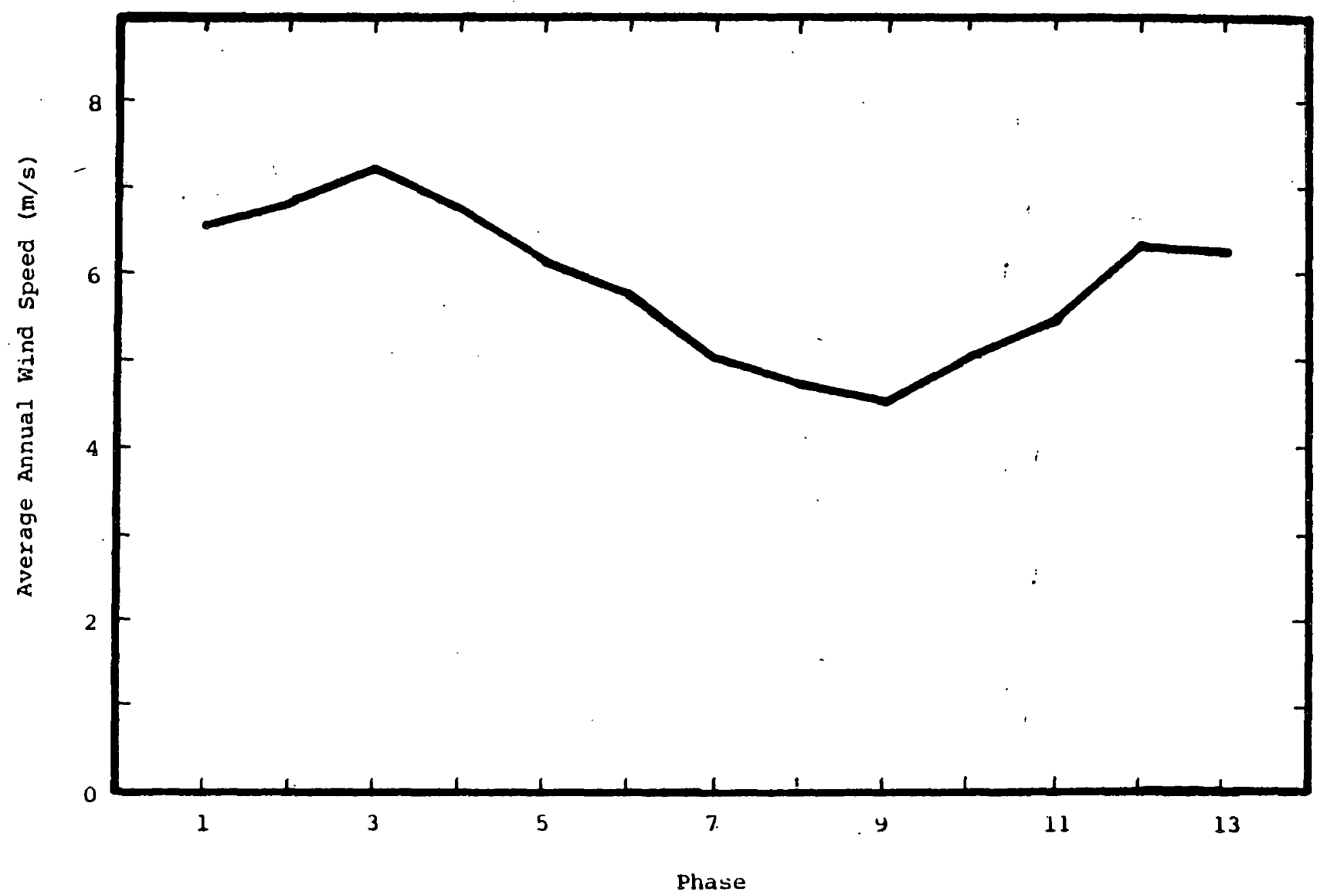

年 


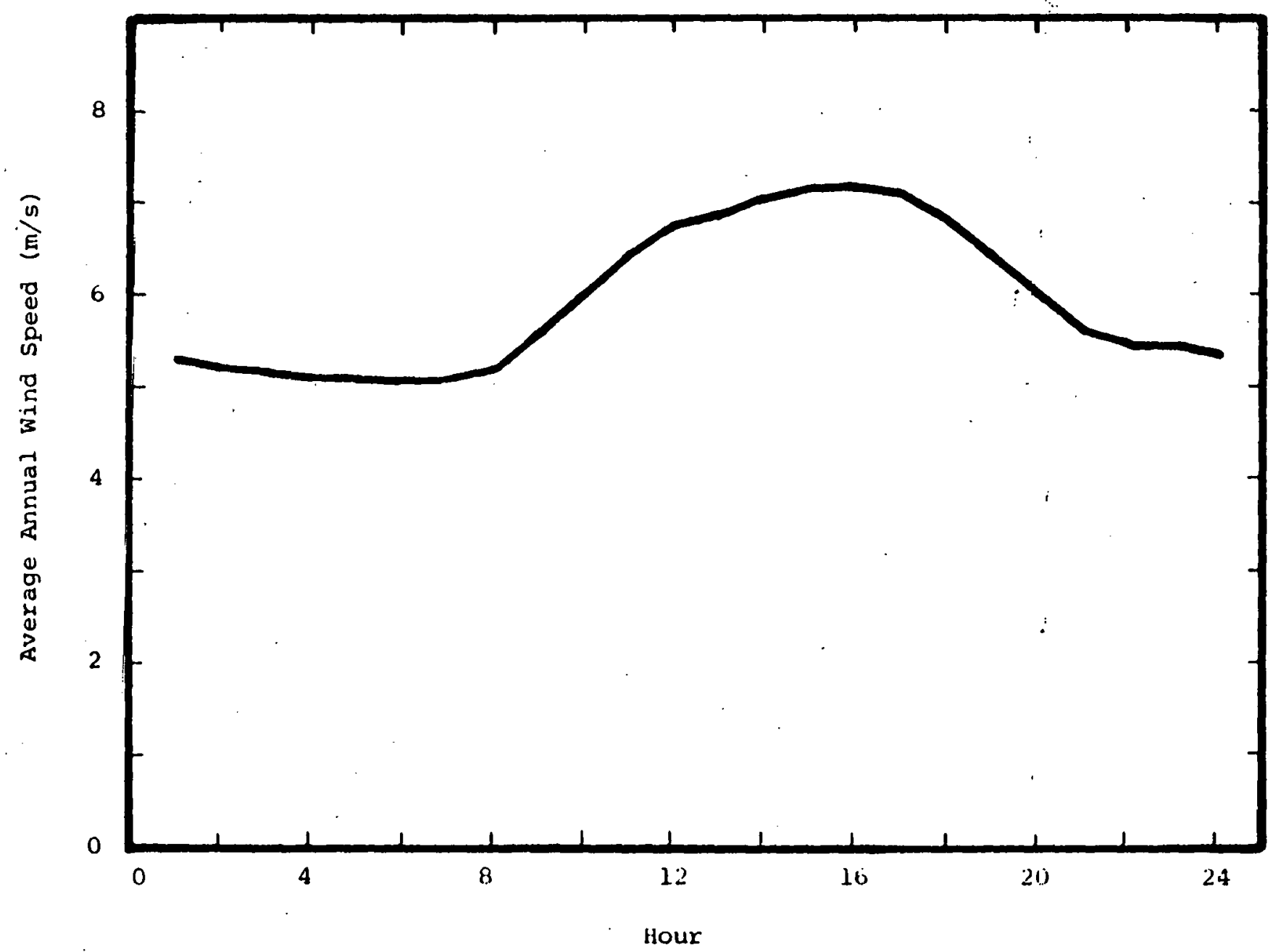

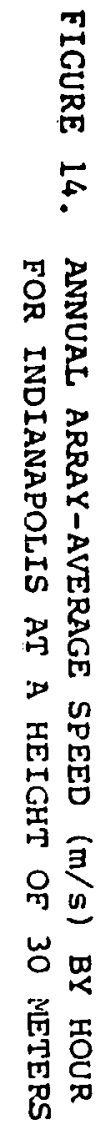




\subsubsection{Performance of Selected Wind Machines in Indiana}

Three wind turbines were selected for an evaluation of potential electrical energy generation in Indiana: NASA/DOE MOD-0, NASA/DOE MOD-OA, and the Millville $100 \mathrm{kw}$. Characteristics of the machines are presented in Table 9. The rated power of each wind turbine falls in a 50-200 $\mathrm{kN}$ range, which seems appropriate for 'small wind energy conversion systems' (SWECS) designated for electric utility use. Note also that the machines span a rated power density range of approximately $90-250 \mathrm{w} / \mathrm{m}^{2}$. Higher rated power densities would not be suitable for Indiana wind regimes. The power performance of the selected wind turbines at various sites in the Indiana area was estimated using the JBF computer programs SERIES and WINDS. The results of these runs are presented in Table 10. The method uses the simple linear regression relationship:

$$
C F=A L R+B L R(\text { VBAR/VR) }
$$

where

$$
\begin{aligned}
& \text { CF is the capacity factor (power out/rated power) } \\
& \text { ALR, BLR are linear regression parameters } \\
& \text { VBAR is the average wind speed at the site } \\
& \text { VR is the rated wind speed of the wind turbine }
\end{aligned}
$$

The annual average capacity factor $\overline{C F}$ is the average of capacity factors calculated for each hour of each phase of the year. The variation of capacity factor with height is further illustrated in Tables 11 and 12 . Note that the highest capacity factors are attained by the NASA MOD-O, which has a rated power density of $93 \mathrm{w} / \mathrm{m}^{2}$. 
Table 9: CHARACTERISTICS OF SELECTED WIND TURBINES

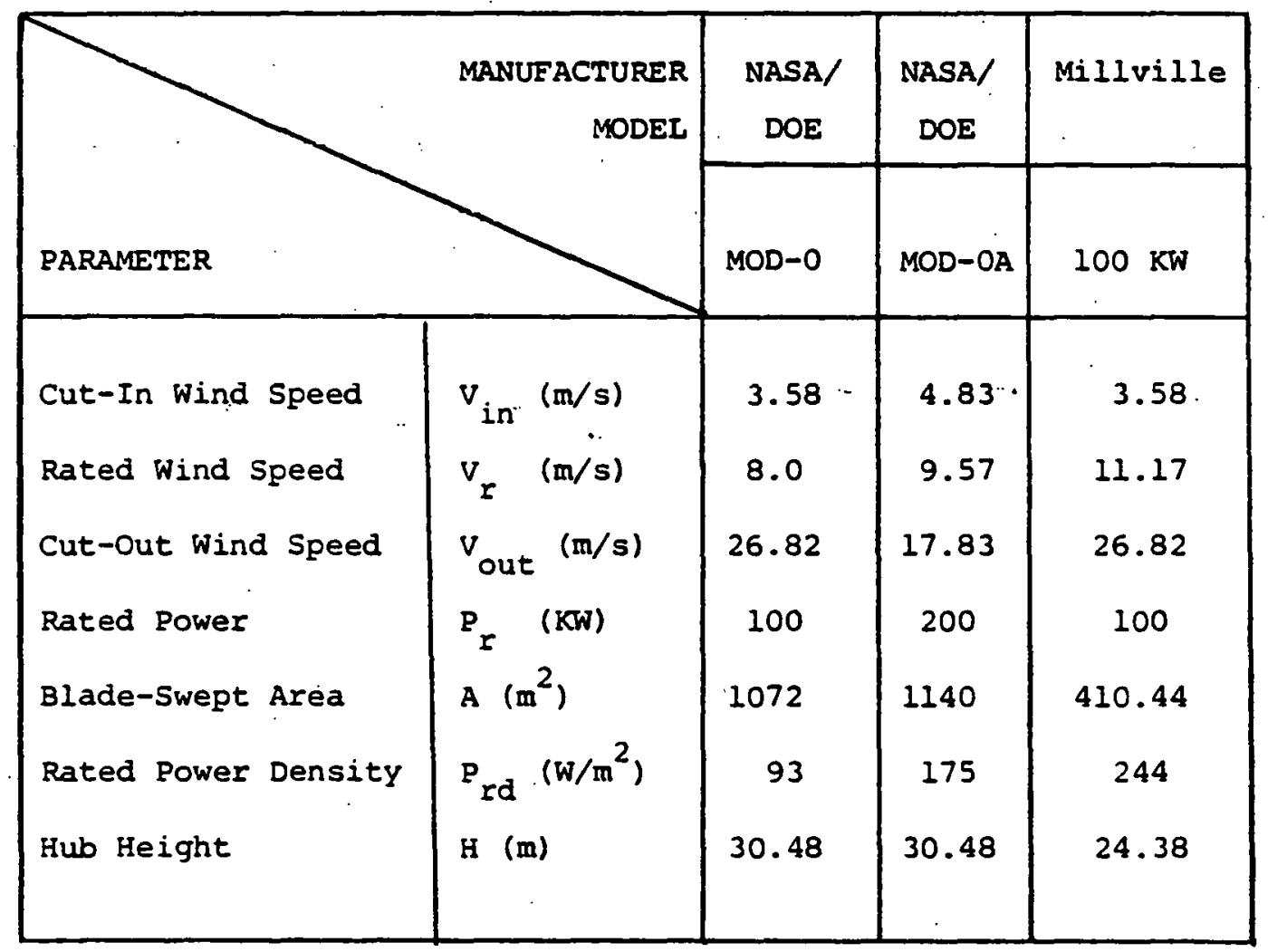


Table 10. LINEAR REGRESSION PARAMETERS AND CAPACITY FACTOR OF SELECTED WIND TURBINES AT HUB HEIGHT AT LOCATIONS IN AND AROUND THE STATE OF INDIANA

\begin{tabular}{|c|c|c|c|c|c|c|c|c|c|c|c|c|}
\hline \multirow{2}{*}{$\begin{array}{l}\text { Site } \\
\text { Code }\end{array}$} & \multirow[t]{2}{*}{ Site } & \multirow{2}{*}{$\frac{(\mathrm{m} / \mathrm{s})}{24.38}$} & at Height (m) & NASA/DOE & MOD-0, & \multirow{2}{*}{$\frac{30.48 \mathrm{~m}}{\overline{\mathrm{CP}}}$} & \multicolumn{2}{|c|}{ NASA/DOE MOD-OA. } & \multirow{2}{*}{$\frac{30.48 \mathrm{~m}}{\overline{\mathrm{CF}}}$} & \multicolumn{3}{|c|}{ Millville $100 \mathrm{KW}, 24.38 \mathrm{~m}$} \\
\hline & & & 30.48 & ALR & BLR & & ALR & BLR & & ALR & BLR & $\overline{\mathrm{CF}}$ \\
\hline IP & Indianapolis & 5.65 & 5.95 & -.46778 & 1.22797 & .465 & -.50136 & 1.26029 & .321 & -.42029 & 1.18054 & .217 \\
\hline TH & Terre Haute & 4.99 & 5.25 & -.37832 & 1.14133 & .404 & -.43325 & 1.18211 & .270 & -.33452 & 1.03471 & .174 \\
\hline FW & Fort Wayne & 6.19 & 6.49 & -.33408 & 1.06388 & .536 & -.45599 & $: 1.22683$ & .409 & -.40546 & 1.18915 & .291 \\
\hline SB & South Bend & 5.92 & 6.21 & -.33544 & 1.07174 & .508 & -.43279 & 1.19424 & .383 & -.38876 & 1.15287 & .263 \\
\hline EV & Evansville & 4.54 & 4.78 &.- .32697 & 1.07528 & .352 & -.37385 & 1.10017 & .234 & -.26114 & 1.91070 & .151 \\
\hline LV & Louisville & 5.18 & 5.45 & -.41388 & 1.17461 & .413 & -.45804 & 1.22076 & .283 & -.35752 & 1.08241 & .185 \\
\hline
\end{tabular}

NOTES :

$\vec{V}$ is the annual 5-year average wind speed $(\mathrm{m} / \mathrm{s})$ at the indicated height (m), years $1973-77$

ALR, BLR are the linear regression parameters

$\overline{\mathrm{CF}}$ is the annual average capacity factor 
Table 11. CAPACITY FACTORS OF SELECTED WIND TURBINES AT THREE DIFFERENT HEIGHTS AT THE INDIANAPOLIS SITE

\begin{tabular}{|c|c|c|c|c|}
\hline \multirow{2}{*}{$\begin{array}{c}\text { Height } \\
(\mathrm{m})\end{array}$} & $\begin{array}{c}\mathrm{v} \\
(\mathrm{m} / \mathrm{s})\end{array}$ & $\begin{array}{c}\text { NASA/DOE } \\
\text { MOD-0 }\end{array}$ & $\begin{array}{c}\text { NASA/DOE } \\
\text { MOD-OA }\end{array}$ & $\begin{array}{c}\text { Millville } \\
100 \mathrm{KW}\end{array}$ \\
\cline { 3 - 5 } & & .391 & .252 & .193 \\
\hline 20 & 5.41 & .431 & .288 & .220 \\
\hline 30 &. .69 & .4253 & .319 & .243 \\
\hline
\end{tabular}

SITE: Indianapolis (IP) 
Table 12. CAPACITY FACTOR OF MILLVILLE 100KW WIND TURBINE AT LOCATIONS IN AND AROUND THE STATE OF INDIANA

\begin{tabular}{|c|c|c|c|c|}
\hline \multirow{2}{*}{$\begin{array}{l}\text { Site } \\
\text { Code }\end{array}$} & \multirow{2}{*}{ Site } & \multicolumn{3}{|c|}{$\begin{array}{l}\text { Capacity Factor at } \\
\text { Height Above Ground (m) }\end{array}$} \\
\hline & & 20 & 25 & 30 \\
\hline IP & Indianapolis & .193 & .220 & .243 \\
\hline $\mathbf{T H}$ & Terre Haute & .153 & .177 & .198 \\
\hline FW & Fort Wayne & .263 & .295 & .322 \\
\hline SB & South Bend & .236 & .266 & .292 \\
\hline EV & Evansville & .132 & .154 & .173 \\
\hline LV & Louisville & .164 & .188 & .210 \\
\hline
\end{tabular}

Wind Turbine: Millville $100 \mathrm{KW}$ 


\subsection{Calculation of Production Costs}

\subsubsection{WECS Utility Evaluation}

DeWinkel presents the steps any utility may follow in an evaluation of WECS in its expansion plans: 1

Utilities evaluate alternative expansion plans for a given period in the future by a detailed economic analysis. The optimum system of generators meets the energy and reliability requirements with the lowest cost, in present value or annualized cost terms. A WECS utility evaluation contains the following steps, which may slightly vary (Johanson and Goldenblatt 1977; Melton 1977; Marsh 1978):

(1) Choice of wind machines and sites; estimate of desired total installed weCs capacity (often expressed as penetration level of WECS: ratio between WECS and conventional capacity).

(2) Calculation of the cost of production for various levels of wECS capacity. Predicted hour-by-hour wind power output data, based on historical wind speed observations, are subtracted from predicted hour-by-hour load levels that are based on historical load data and expected changes in future loads. These adjusted load levels for the period considered are used in the standard evaluation of electricity production costs with the given mix of conventional generators. These production costs without and with different penetration levels of WECS are used to estimate gross savings (mainly fuel savings) over the total lifetime of the WECS. Given an estimate of lifetime operating and maintenance costs for the WECS, a break-even capital cost for the WECS can be calculated.

Both the fuel-saving mode and the more comprehensive analysis contain these flrst two steps. Note that up to now the conventional generating mix does not change when adding wECS capacity. Thus, fixed costs of the conventional system do not change when WECS capacity is added (provided that transmission and distribution changes are insignificant). Therefore, these costs cancel out and are not considered in a fuel-saving analysis.

(3) Adjustment of the conventional generating mix to find a new optimum for meeting the adjusted load. Both the fixed and variable costs are calculated with varying wECS penetration levels. 
(4) The addition of wECS to a utility system results in a lower loss of load probability (LOLP).*

The effective capacity of the WECS is the amount of additional peak load that the system could meet or the conventional capacity that could be omitted to bring the LOLP back to its original level. This effective capacity determines the capacity credit.

(5) The final major task is the assessment of any potential increase in the operating reserve requirement due to unpredictability of the wind on a daily basis.

By comparing the fixed and variable costs for the conventional sources, capacity credits and operating reserve requirements for different penetration levels of WECS, savings and breakeven costs can be calculated. 
NOTES $(1.2 .1)$

1. DEW, 48-49. 


\subsection{Calculation of Production Costs}

\subsubsection{Dewinkel's Analysis}

DeWinkel's analysis of the application of WECS to the Dairyland Power Cooperative encompassed only savings in energy productions due to WECS. Capacity credit was not considered. The major components of this analysis are presented in Figure 15.

Dewinkel made the following data and procedural assumptions for his analysis: ${ }^{2}$

- WECS are spread over three locations having relatively high annual average wind speeds $(7 \mathrm{~m} / \mathrm{s}$ to $8 \mathrm{~m} / \mathrm{s}$ at a height of 60 meters).

- Two machines were chosen for the study: one having a rated power density of $90 \mathrm{w} / \mathrm{m}^{2}$ and the other with $220 \mathrm{w} / \mathrm{m}^{2}$.

- Three levels of installed WECS capacity were chosen: $100 \mathrm{MW}$, $200 \mathrm{MW}, 400 \mathrm{MW}$. These capacities were assumed to be in place in 1985 and were kept constant throughout the period of analysis.

- Economic conditions:

$$
\begin{aligned}
& \text { Inflation rate }=78 \\
& \text { Discount rate }=98 \text { (includes inflation) }
\end{aligned}
$$

- Fuel price increases $=68,78,88,108$, or 128 per year, including inflation

- Values of WECS operating and maintenance costs, taxes, and insurance in percentage of the capital cost:

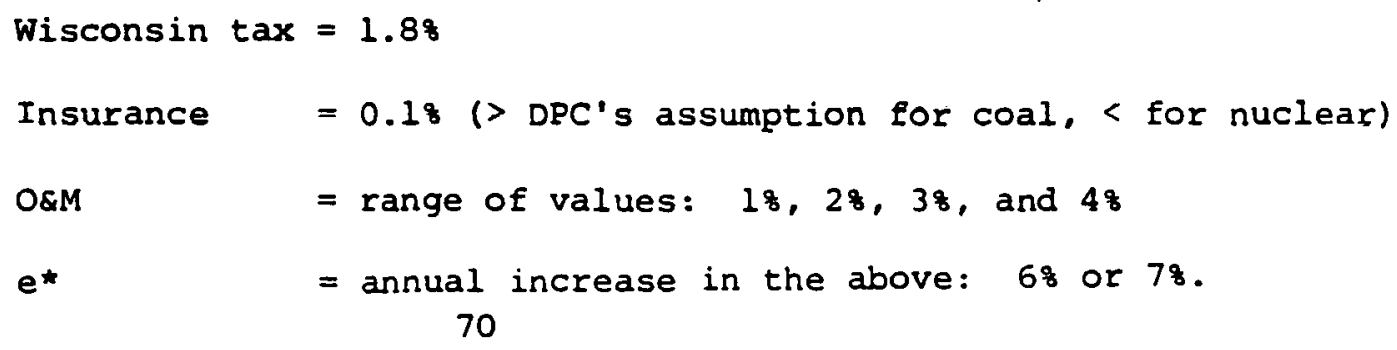


FIGURE 15. FLOW CHART OF MAJOR COMPONENTS OF THE AVALYSIS

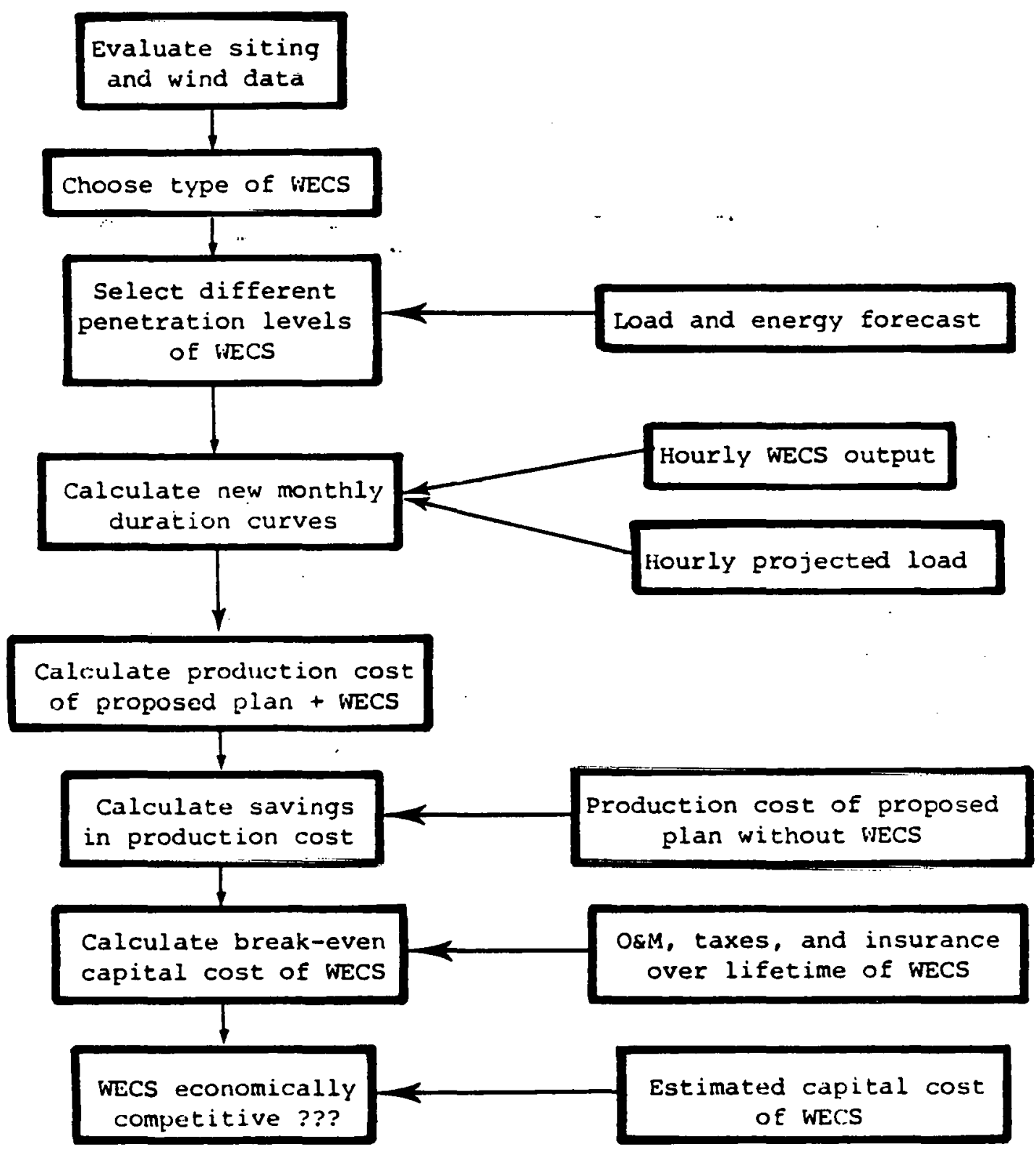


- A computer model was used to construct new monthly load duration curves. WECS power output based on five years of wind data is subtracted from the 1985 projected utility loads on an hour-by-hour basis.

- The analysis does not include considerations of capacity credit.

- Savings over the 35 year life of the WECS are calculated assuming constant fuel savings and a constant growth rate of cost for all fuels, variable OsM, and purchased energy. 
NOTES $(1.2 .2)$

1. DEW, 64 (Figure 17).

2. DEW, 63-68. 


\subsection{Calculation of Production Costs}

\subsubsection{JBF Generic Planning Process}

The procedure used by utilities in the selection of future conventional equipment is outlined in the JBF study and compared with the generic planning process for WECS: ${ }^{1}$

To select conventional equipment for future needs, most utilities in the United States use the same basic procedure, which. includes :

- estimating the peak load for a future year (analysis year), or future years;

- projecting the load duration curve to the analysis year, based on the estimated future peak load; and

- dispatching various hypothetical equipment mixes against the load duration curve for the analysis year, and calculating the associated total annual costs of operation to select an optimum future mix of conventional sources.

The objective of this procedure is to be able to select a mix of conventional sources that will meet estimated loads, at the lowest total annual cost consistent with safe, reliable service.

The procedure used in the generic planning process was to estimate the life cycle savings generated by the inclusion of WECS into the utility equipment mix from the savings generated by the WECS in a single year. The total annual cost of meeting the load is the sum of the fixed and variable costs. Fixed costs include capital costs, taxes, labor, and other expense's that are incurred regardless of how much each unit is used. The fixed cost of a generating unit is expressed on an equivalent uniform annual cost basis. This is the constant stream of fixed costs over the life of a unit, whose present value (discounted at the cost of capital with tax rates taken into account) is equal to the present value of anticipated actual fixed cost outlays over the life of the unit. Variable costs are those that are incurred when units are dispatched, and are equal to the fuel and variable maintenance costs.

The method developed in the JBF program for generation planning and assessment involving wECS is diagrammed in Figure 16.2 For zero WECS 
FIGURE 16. METHODOLOGY FOR CALCULATING IMPACT OF WECS TO UTILITY OPERATING COSTS

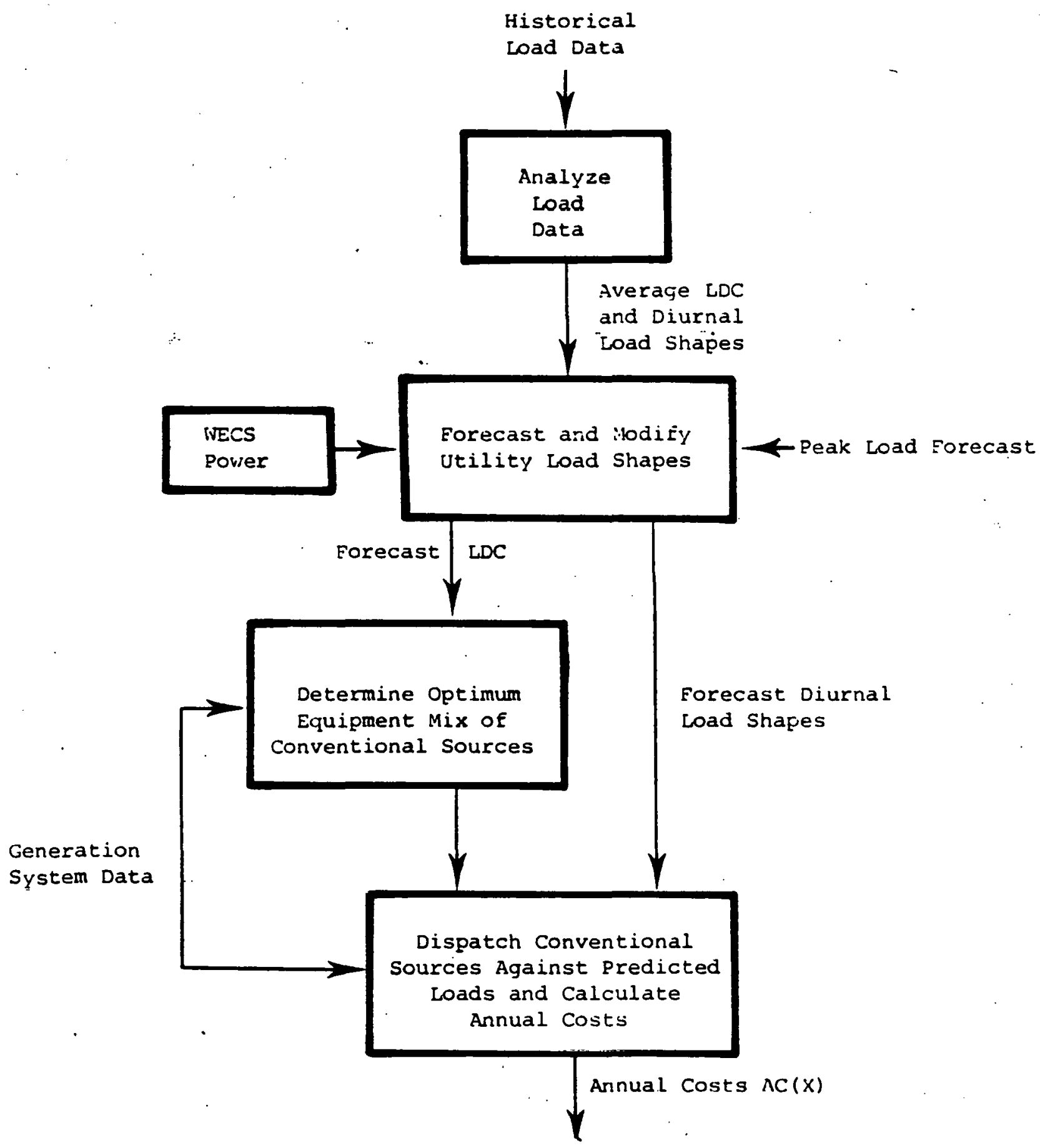


penetration this method reduces to the procedure previously described. The analysis includes the following steps.

(1) Obtain historical hourly load data and develop average diurnal load shapes (DLS) and a load duration curve (LDC).

A typical DLS and LDC are shown in Figure 17.

(2) Project the average DLS and LDC into the analysis year and modify them according to the WECS power output.

The curves are projected from the base year of the averages to the analysis year by multiplying each point on the curves by the ratio of the base year peak load to the estimated peak load of the analysis year.

Modified diurnal load shapes are created by subtracting from the forecast DLS's, hour-by-hour, the wind power produced by the WECS. These modified DLS's are then used to create the modified forecast load duration curve. The modified forecast LDC then represents the annual load that must be satisfied by conventional generating equipment in the analysis year.

(3) Determine the optimum mix of conventional sources.

The forecast IDC is used by the utility to determine an optimum mix of conventional equipment. At this point, two modes of WECS utilization are available: fuel saver and reoptimized mix. If WECS are to be used as a fuel saver, they would be added to the optimum mix and the annual fuel savings attributable to WECS would be calculated. The second approach involves reoptimizing the mix after the effect of WECS on the load has been applied. The modified forecast LDC is used for the reoptimization. 
FIGURE 17. TYPICAL UTILITY DIURNAL LOAD SHAPE AND LOAD DURATION CURVE

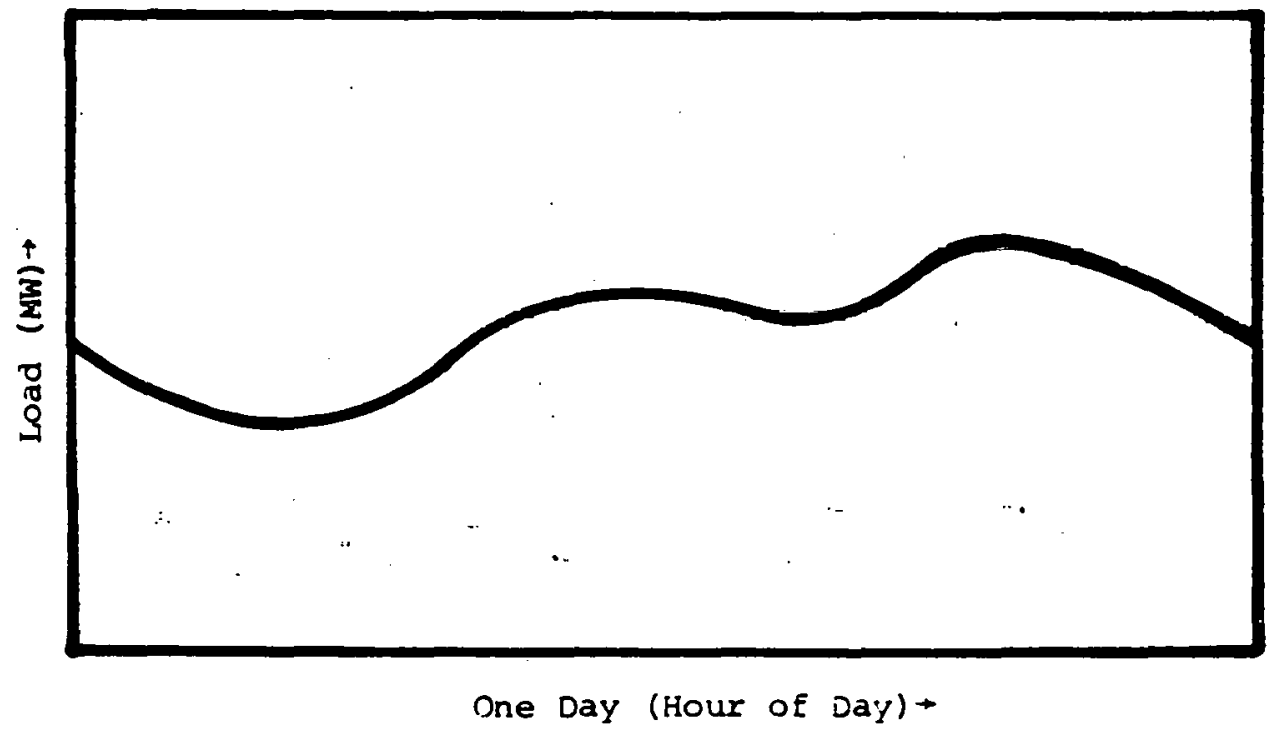

Typical Diurnal Load Shape

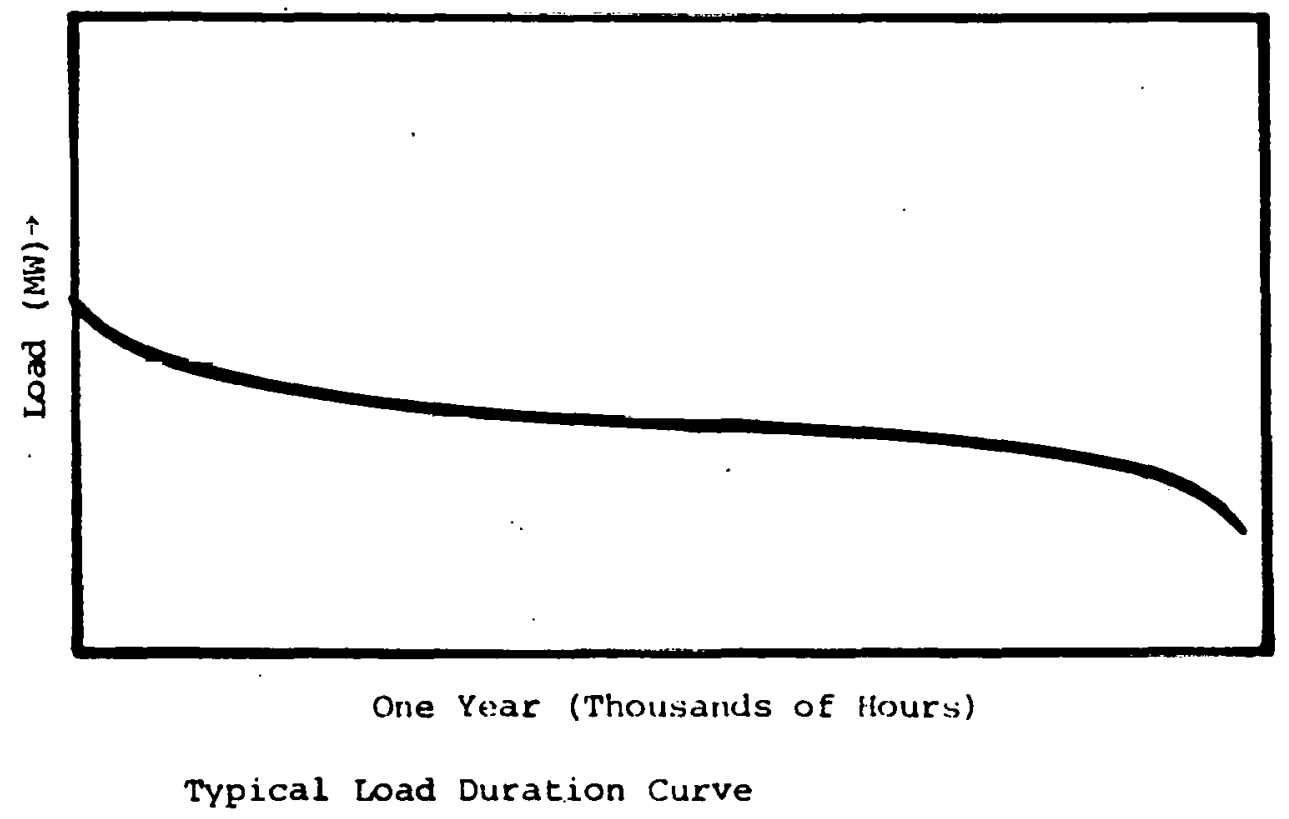


(4) Dispatch the utility mix of conventional sources against the expected diurnal load shapes.

First the optimum mix with no wECS is dispatched against the forecast DLS's. The annual cost (fuel and fixed) is designated $A C(0)$, the zero indicating no WECS. Conventional sources are then dispatched against the modified forecast DLS's, which were calculated assuming a certain WECS capacity, expressed, say, in terms of percentage of the forecast peak load. (If investigating the reoptimized mix mode, use the reoptimized mix of conventional equipment; otherwise, retain the fuel saver optimum mix.) There will be a reduction in the costs accrued to conventional sources because the WECS have assumed some of the load. Letting $A C(x)$ designate the new annual cost, the annual "savings" achieved by adding a certain amount of wECS (X\% of forecast peak) are:

$$
\triangle A C(x)=A C(0)-A C(x)
$$

By repeating this procedure for various percentages of WECS, one may obtain a curve that shows the change in annual cost as a function of WECS penetration. 
NOTES $(1.2 .3)$

1. JBF1, 5-1.

2. JBF1, 5-2 (Figure 5-1).

3. JBFl, 5-4 (Figure 5-2). 


\subsection{Calculation of Production Costs}

\subsubsection{Southwest Research Institute Cost Goal Analysis}

The Southwest Research Institute study identifies the energy value as the "most straight forward and obvious value of wind generated energy on a large network." 7 Evaluation of the wind power energy value benefits to the Southwestern Public Service Company (SwPS) (or for any utility) involves the following factors: ${ }^{2}$

(1) Wind turbine-generatör output vs. wind velocity characteristics.

(2) Average wind velocity at various times of the day and for each month of the year.

(3) Predicted power output from the wind generator for various times of the day for each month of the year, and total annual energy generated.

(4) Load pattern characteristics and corresponding generation cost for Southwestern Public Service Company.

(5) Annual value of the $\mathrm{kWh}$ of expected generation using actual 1975 generation costs and expected future fuel costs.

(6) The amount of investment that could be justified to provide the annual savings equal to the value of the $k$ Wh generated.

Two modes of WECS operation are considered: run-of-the-wind operation without storage and wind power with compressed air storage. For the runof-the-wind mode, the value of the fuel savings which can be expected from a WECS is determined by first computing the total annual fuel cost of the system operating without WECS, and then subtracting, from this amount the total fuel cost with wECS. 
Yearly fuel costs are calculated by an optimizing economic dispatch program developed by SwPS. Inputs to the computer program include: ${ }^{3}$

- A system model of the SwPS network and generation plants

- The fuel consumption rates and raw fuel costs for each of the generating stations of the system

- The values of the expected and actual load on the system for each hour of the day

To calculate fuel costs of the system with wECS, "net" demand curves are entered into the optimal dispatch program. These curves are found by subtracting, on an hourly basis, the expected WECS power output from the known load schedules of the utility, for each month of the year.

For the case of wind power plus compressed air storage, a capacity value is assigned to the WECS in addition to the fuel savings. That value is based on the levelized. annual carrying charges of the most competitive alternate peaking capacity, in this case, open-cycle gas turbines.

The allowable investment which could be justified by the energy value of WECS was computed using an economic analysis program developed by SwPS. A brief summary of this program follows: 4

The program calculates depreciation, taxes, Interest and other fixed charges annually, and together with revenue (fuel savings plus capacity value) and experses, calculates cash flow and earning each year. These annual results are then discounted and accurmulated to produce the earnings rate (fuel savings in dollars/year) on investment. By iterating the calculations, the investment that can be justified by a given annual revenue (fuel savings) can be determined. In all of the calculations made here, this iteration was carried out on the basis of a 68 return on investment.

The costs of capital used include 98 interest on bonds, 98 preferred dividends, 488 federal income tax, 1.398 local taxes on investment and 98 discount rate. These values are those currently in use by SwPS in economic evaluation. 
The results of the computer analysis are summarized in nomograph

form (Figure 18). 5 An explanation of its use is reproduced below: 6

On the horizontal axis of the chart, to the left of center, appears a scale marked "MW Hours per Year". Here is plotted the result of the application of windpower-duration data for a given site, to the performance characteristics of the specific WTG under study. The vertical dotted line to the extreme left, for example, originates on the axis at a point representing the total average annual energy, 6848MWh, that would be generated by a modern WTG of $1000 \mathrm{KW}$ rating, rated at a wind speed of 8 meters per second at: 60 meter hub height in Amarillo, Texas wind regime.

The vertical axis of the chart is labeled "Fuel Savings in Dollars per Year (Levelized)". Along this axis are plotted the energy values as calculated by the previously developed methodology, using the optimal dispatch computer technique. The word "levelized" signifies that in certain instances the basic fuel costs for the system have been allowed to escalate at a given rate over the total life of the WTG, in this case 30 years. In order to levelize these costs, the computer sums the yearly cost for fuel over the 30-year period, and divides by 30 to produce an annual levelized energy value or savings.

The diagonal straight lines originating at the zero intercept of the $X$ and $Y$ axes extending to the left, are labeled "Fuel Costs in Cents per Kilowatt Hour". The intersection of lines erected vertically from the proper "MWh per year" point on the $X$ axis,.. with these "fuel cost" lines permits fuel savings in dollars per year to the SwPS system, for any WTG energy output and any fuel cost, to be determined. This is accomplished by moving horizontally on the chart from the intercept of the appropriate lines, to the $Y$ axis in the center of the nomograph.

The horizontal axis of the chart on the right-hand side of the vertical axis is labeled "Dollars per Kilowatt Investment". Along this axis appears the dollar investment which can be justified by a given fuel saving value in accordance with SwPS cost of capital, perferred dividends, federal income tax, etc. This "allowable investment" is found by extending the horizontal line to the right from the "Fuel Savings per Year" axis, to the appropriate right-hand diagonal line marked "Annual Investment Cost plus Operation and Maintenance". On the figure, these diagonal lines have been drawn to conform to zero, $\$ 10,000$ and $\$ 20,000$ per year fixed operation and maintenance costs. Obviously, other values could be 


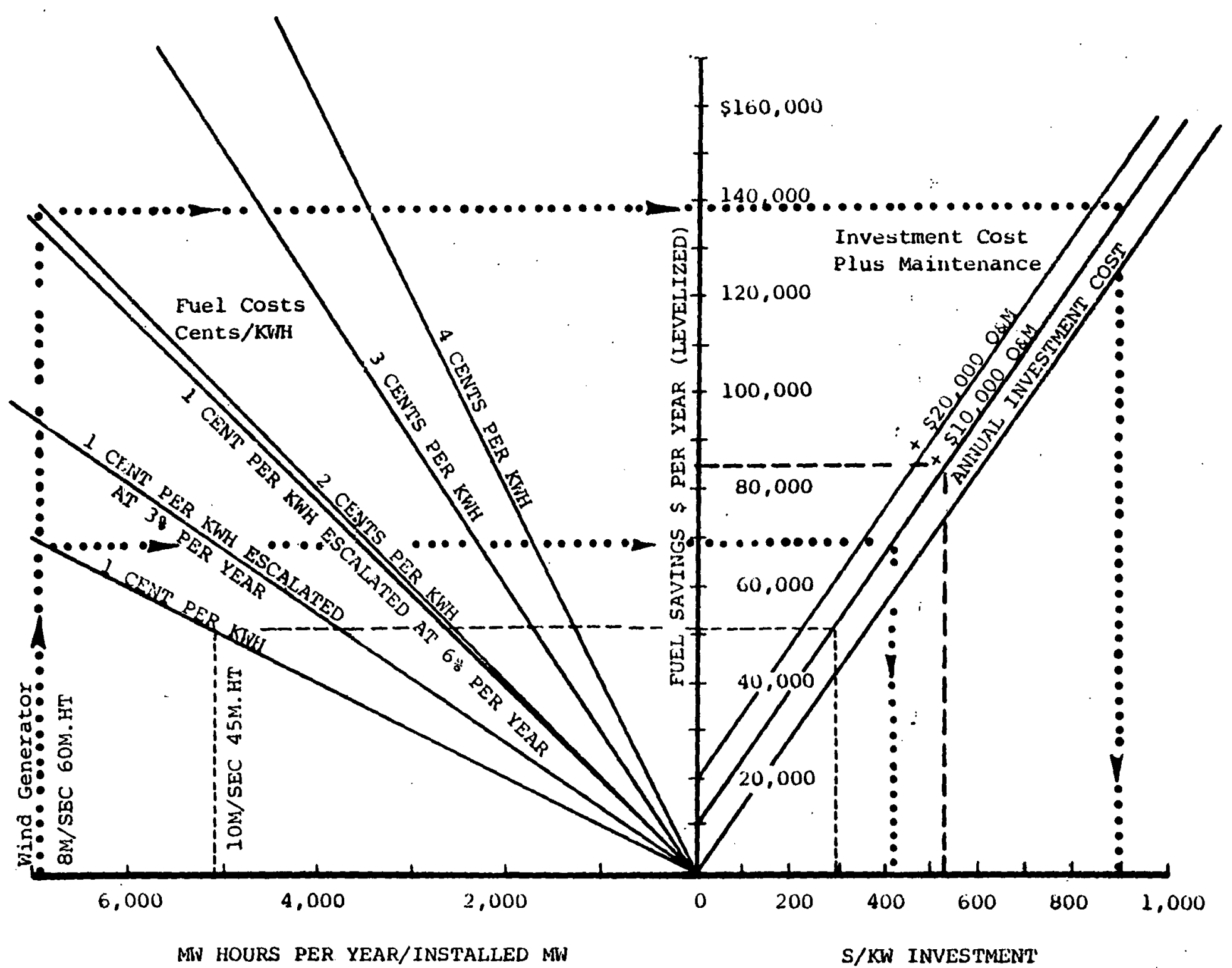

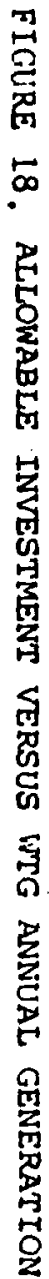

MN HOURS PER YEAR/INSTALLED MW 
chosen as well, since the lines are parallel, and their dollar amount is derived from the "fuel

savings" axis.

All costs are normalized to 1975 dollars. When using the Nomograph for a wind turbine generator (WTG) system incorporating a storage system, calculate the "equivalent fuel saving" (actual fuel saving plus capacity value) for each installed MW of WTG and enter the nomograph at the vertical axis. 
NOTES $(1.2 .4)$

1. SWRI, 127 .

2. SWRI, 128-29.

3. SWRI, 129.

4. SWRI, $134,137$.

5. SWRI, 138 (Figure 41).

6. SWRI, $137,139$. 


\subsection{Calculation of Production Costs.}

\subsubsection{Sensitivity Analyses}

The assumptions of an economic analysis of WECS can obviously have a great effect on the final outcome of whether or not 'WECS are competitive. Some parameters are more sensitive to change than others. Furthermore, there are two types of parameters that are being examined in a sensitivity analysis: those affecting the entire analysis, from generation planning through to life cycle costs, and those that primarily affect the life cycle costs. 1

DeWinkel examined the break-even capital cost of WECS as a function of fuel price increases and O\&M costs. 2 Break-even cost varies significantly with each of these parameters. Dewinkel used values of $78,88,108$, and 128 for rate of fuel price increase (in environment of 78 inflation), and 18, 3\%, and 58 for WECS O\&M (percent of capital cost). He also assumed 1.88 property tax rate and 0.18 insurance. DeWinkel found that a property tax exemption for DPC's WECS will increase the break-even capital cost of a WECS by about $208 .^{3}$

The JBF study identified several critical parameters in its sensitivity analysis for the case of NEGEA utilizing the reoptimized mix mode. The results of the sensitivity analyses are summarized in Figure 19.4 These analyses yielded a number of insights into the effects of government actions or market forces on the value of wECS, which insights are reproduced below: ${ }^{5}$

- Any government action, such as a reduction in the cost of capital, should only be applied to the WECS and not to all of the hardware that the utility purchases. Unless this is 


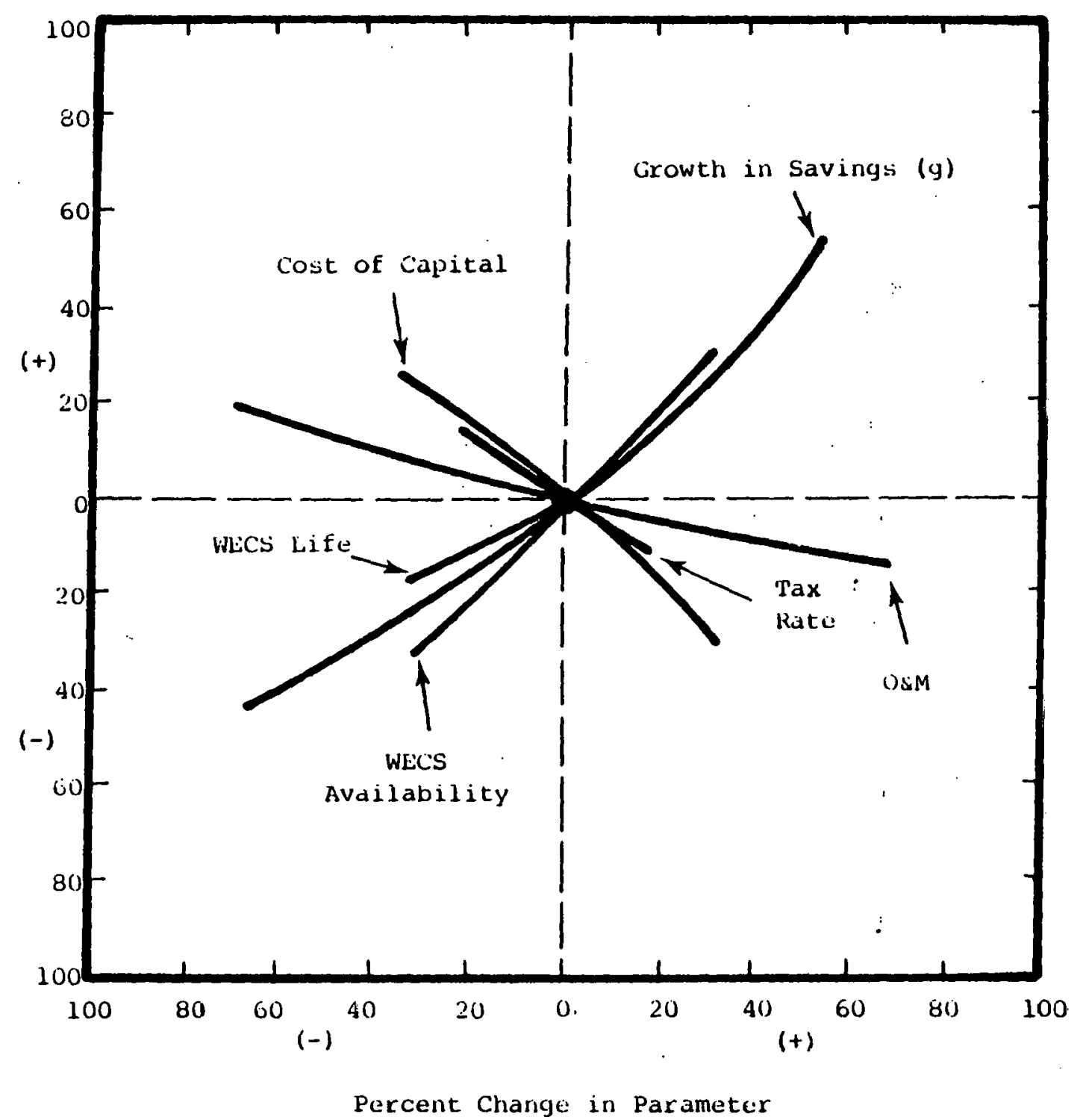

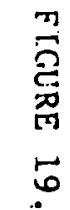

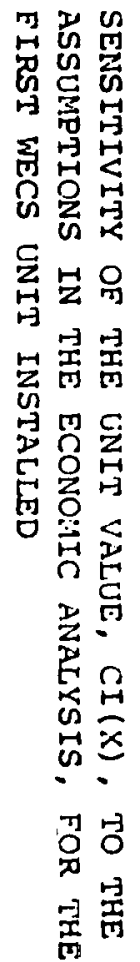

Percent Change in Parameter 
done, the utility optimization procedure will substantially reduce the effectiveness of the change.

- A sensitive parameter affecting WECS unit value is the growth in annual savings. This is primarily dependent on elements such as inflation and fuel prices.

- WECS unit value is sensitive to O\&M costs. Any government research or engineering activity that would reduce O\&M costs would increase the unit value of WECS.

- Reducing the effective tax rate on the revenues associated with the WECS would increase the unit value.

- WECS unit value is sensitive to the cost of capital. If the government were able to reduce the utilities cost of capital for the WECS equipment this could have a significant impact on what the utility could pay for the wECS.

- WECS unit values are relatively insensitive to insurance rates, land costs, and appreciation in land costs.

- Improving the availability of WECS would have a significant impact on the value of WECS to a utility. This might be achieved through demonstration programs to identify WECS problem areas and government R\&D to improve WECS availability .

- The economic life of a WECS will have a significant impact on its value to a utility, especially as higher fuel costs occur in future years. Government R\&D to extend WECS lifetime might be justified.

- Finally, the graph showing Figure 19 shows the effect of varying only one economic parameter at a time. Clearly, modest growth in savings, coupled with low cost capital, a reduced tax 
rate, increased WECS availability, and reduced O\&M costs could have a very large effect on the value of WECS and the impact of changing multiple parameter assumptions in the economic analysis, for a family of realistic scenarios, would be a beneficial activity. 
NOTES $(1.2 .5)$

1. JBF1, 8-39.

2. DEW, 75-77.

3. DEW, 116 .

4. JBFl, 8-44 (Figure 8-20).

5. JBF1, 8-45. 


\subsection{Reduction in Fuel Consumption}

The reduction in fuel usage by a utility as a function of WECS penetration and the consequent savings in fixed and variable costs are dependent upon the following factors:

- Fuel requirements of the conventional equipment mix

- WECS penetration level

- Mode of WECS utilization (fuel saver vs. reoptimized mix)

- Escalation of fuel prices

The equipment used in the utility's conventional generation mix may vary considerably in heat rate and fuel cost, as well as overall fixed cost. Generally speaking, low variable-cost generation is achieved only through technologically complex generating units of high fixed cost (e.g. nuclear plants). Conversely, low fixed-cost units typically have high variable costs (e.g gas turbines and diesel units). The JBF study reports the following equipment selection options available to NEGEA: ${ }^{1}$

\begin{tabular}{lcc} 
Type of Plant & $\begin{array}{c}\text { Total Annual } \\
\text { Fixed Cost } \\
(\$ / \mathrm{kW})\end{array}$ & $\begin{array}{c}\text { Incremental } \\
\text { Cost of Energy } \\
\text { (mills } / \mathrm{kWh})\end{array}$ \\
\cline { 2 - 3 } & 210 & 5.5 \\
Oil-Fired & 80 & 30.1 \\
Gas Turbines & 60 & 41.0
\end{tabular}

A similar relationshlp is evident in the cost characteristics of the Dairyland power Cooperative's generation alternatives: ${ }^{2}$

$\begin{array}{cccc}\text { Unit } & \begin{array}{c}\text { Fuel } \\ \text { Type }\end{array} & \begin{array}{c}\text { Capital } \\ (1985 \$ / \mathrm{kW})\end{array} & \begin{array}{c}\text { Fuel Consumed } \\ (1985 \$ / \mathrm{MBtu})\end{array} \\ \text { Alma \#7 } & \text { coal } & 749 & \\ \text { Tyrone \#1 } & \text { nuclear } & 945 & 2.27 \\ & & & 0.76\end{array}$


An exceptional case is provided by the Southwest Public Service Company (SwPS). All units on the SwPS system are fired by natural gas. ${ }^{3}$ The average annual fuel cost in 1975 was $\$ 0.0785 / \mathrm{kWh} .^{4}$

The fuel types used by the three aforementioned utilities are indicated in the table below:

\begin{tabular}{lcccc} 
& \multicolumn{3}{c}{ Utility } \\
\cline { 2 - 4 } Type of Unit & & DPC* & NEGEA & SwPS \\
\hline Base-loaded & $\mathrm{N}, \mathrm{C}$ & $\mathrm{N}, \mathrm{O}$ & $\mathrm{G}$ \\
Intermediate & $\cdots$ & $\mathrm{C}$ & $\mathrm{O}$ & $\mathrm{G}$ \\
Peaking & $\mathrm{C}, \mathrm{O}$ & $\mathrm{O}$ & $\mathrm{G}$ \\
$\mathrm{N}=$ nuclear & & & \\
$\mathrm{C}=$ coal & & & \\
$\mathrm{O}=$ oil & & \\
$\mathrm{G}=$ natural gas
\end{tabular}

Generating units are dispatched by a utility so as to provide power at the lowest variable cost. As load increases, power to meet that incremental increase in load is provided by the next lowest cost generator. Conversely, as load decreases, units with highest variable cost are taken off line. If WECS are being used to satisfy some of the load, then those relatively higher variable costs which would have otherwise been incurred may be attributed to the WECS as savings in fuel usage and fuel cost.

There are two modes of WECS utilization that need to be investigated. In the fuel saver mode, WECS are added to a mix of conventional equipment that has been optimized to meet the forecast load. In the reoptimized mix mode, the forecast load duration curve is modified by subtracting the

*The Dairyland Power Cooperative also includes a hydroelectric generating station, though its contribution to the system is less than 28 of the total capacity. 
contribution of the WECS and the mix of conventional sources is reoptimized to meet the modified forecast load. Reoptimization is performed for each level of WECS penetration.

As WECS penetration increases, the amount of savings in annual costs increases at a decreasing rate. This is due to the fact that at higher values of on-line WECS, a larger proportion of wECS power is dumped and less expensive fuel is being replaced. This effect is observed for both the fuel saver and the reoptimized mix mode. However, for the reoptimized mix mode one observes a shift from base-loaded units to peaking units with increasing wECS penetration, resulting in a fixed cost saving not enjoyed by the fuel saver mode (Figure 20 )..$^{5}$ As there is no change in the mix of conventional equipment for the fuel saver mode, and hence no fixed cost change, the difference in annual cost is entirely attributable to fuel savings (Figure 21 ).

The amount of fuel saved is approximately the same for both modes at low levels of on-line wECS. At higher levels, the fuel saver mode saves more fuel than the reoptimized mix mode (Figure 22).

For large-percentage WECS (20\% and up) the difference in annual cost is greater for the reoptimized mix mode than for the fuel saver mode (Figure 23).

Another factor affecting fuel cost savings attributable to wECS is the rate of escalation of fuel prices. Sensitivity analyses carried out in the JBF study show that variation in the growth rate of fuel prices has a minimal effect on the difference in annual cost for all levels of WECS penetration considered. ${ }^{9}$ A +208 variation in the average annual growth rate of No. 6 fuel oil prices resulted in a \pm 48 variation in the difference in annual costs over the full range of wECS levels. The same \pm 20 variation 
FIGURE 20. DIFFERENCE IN 1985 ANNUAL COSTS FOR REOPTIMIZED MIX

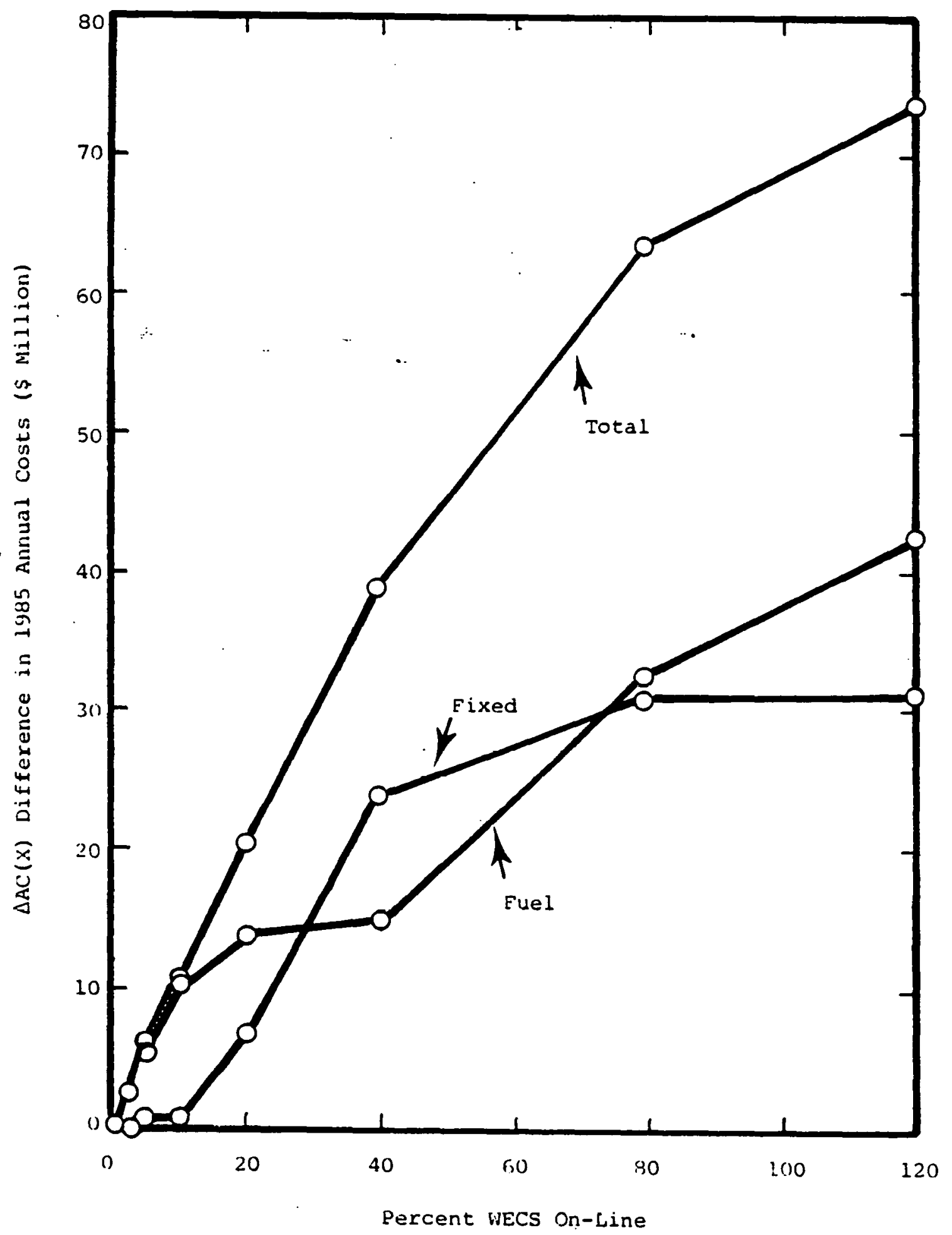


FLCURE 21. DIFFERENCE IN 1985 ANNUAL COSTS FOR THE FUEL SAVER MODE

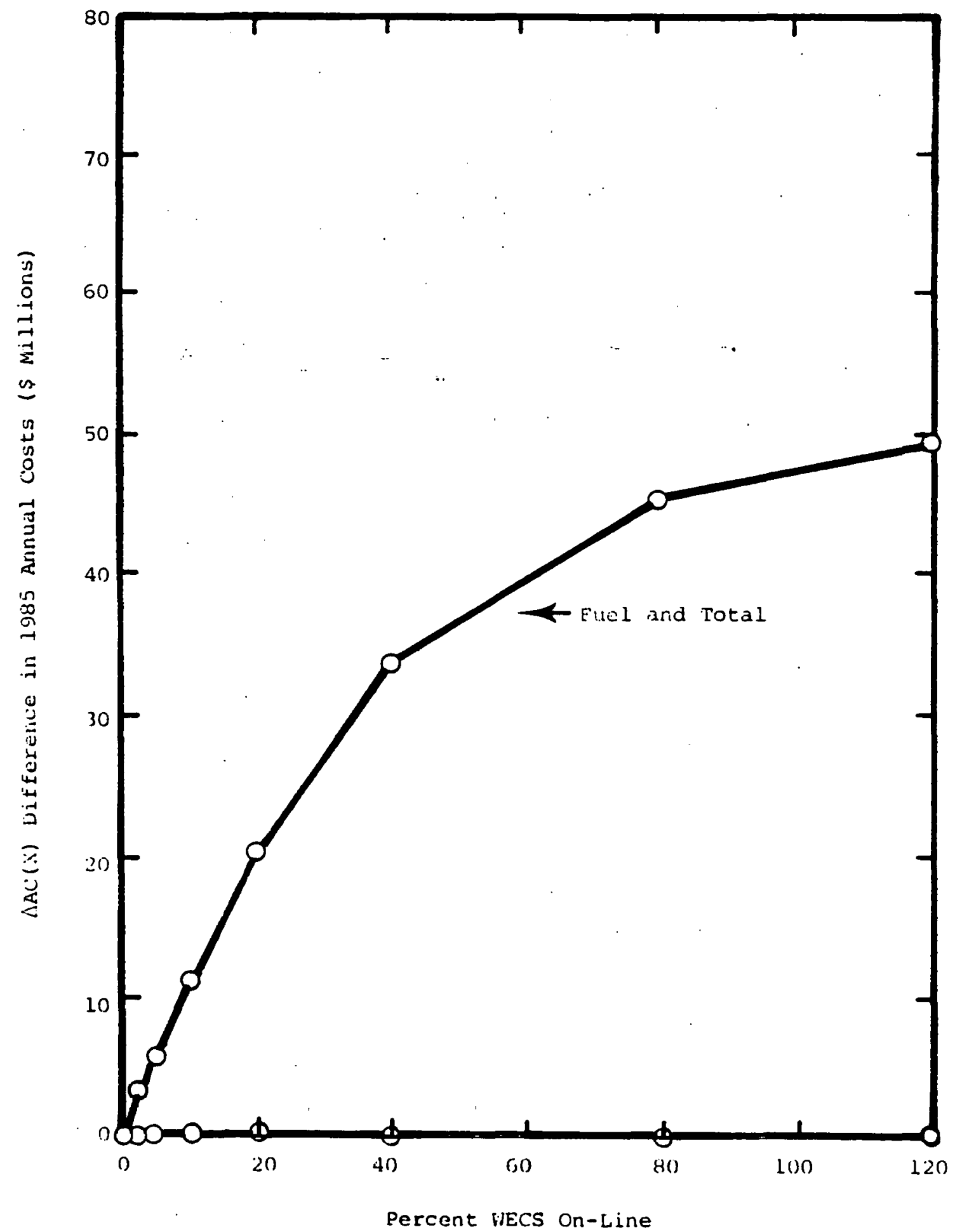


FIGURE 22. 1985 FUEL SAVED BY ADDITION OF WECS TO UTILITY

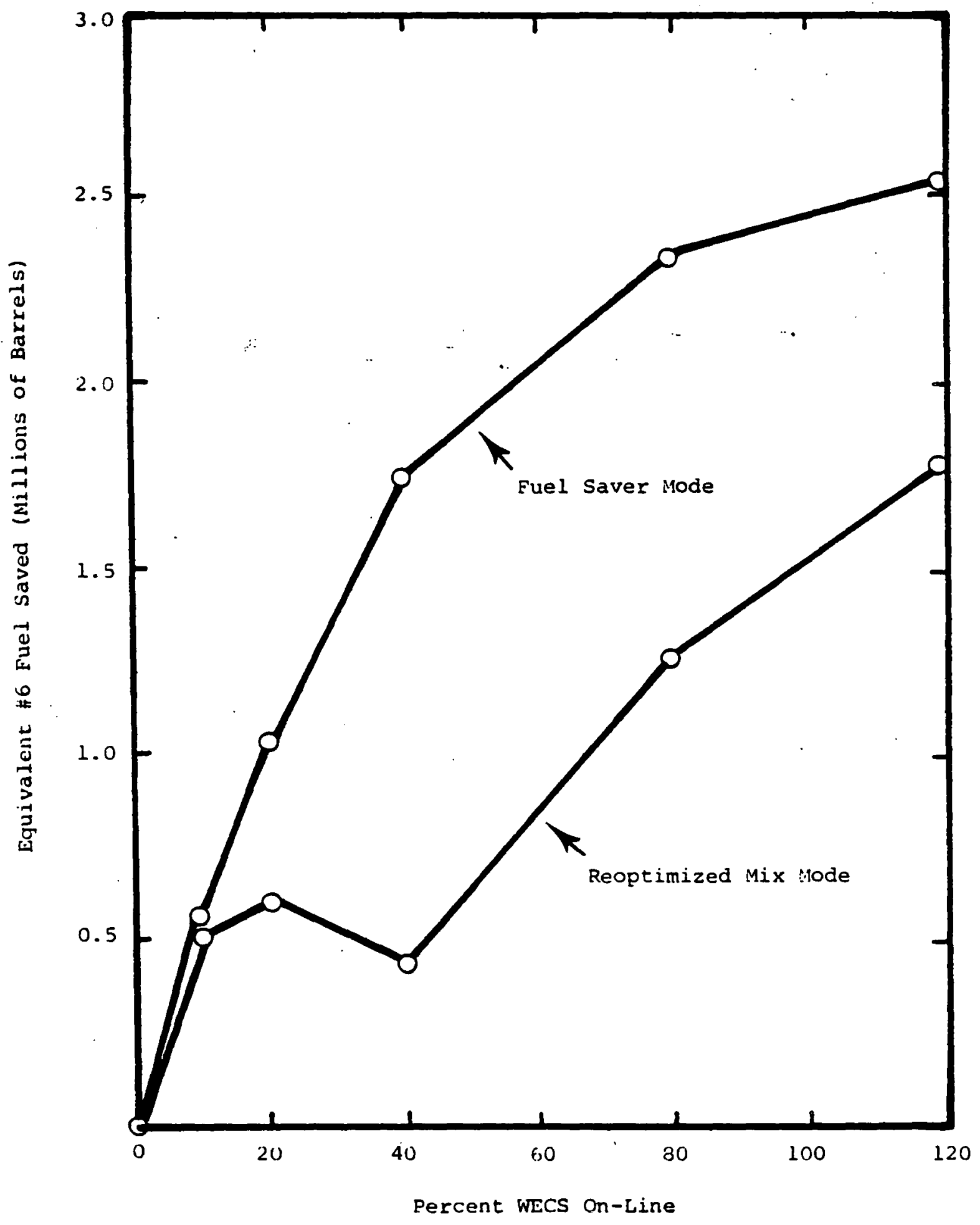


FIGURE 23. DIFFERENCE IN 1985 ANNUAL COSTS FOR FUEL SAVER AND REOPTIMIZED MIX CASES

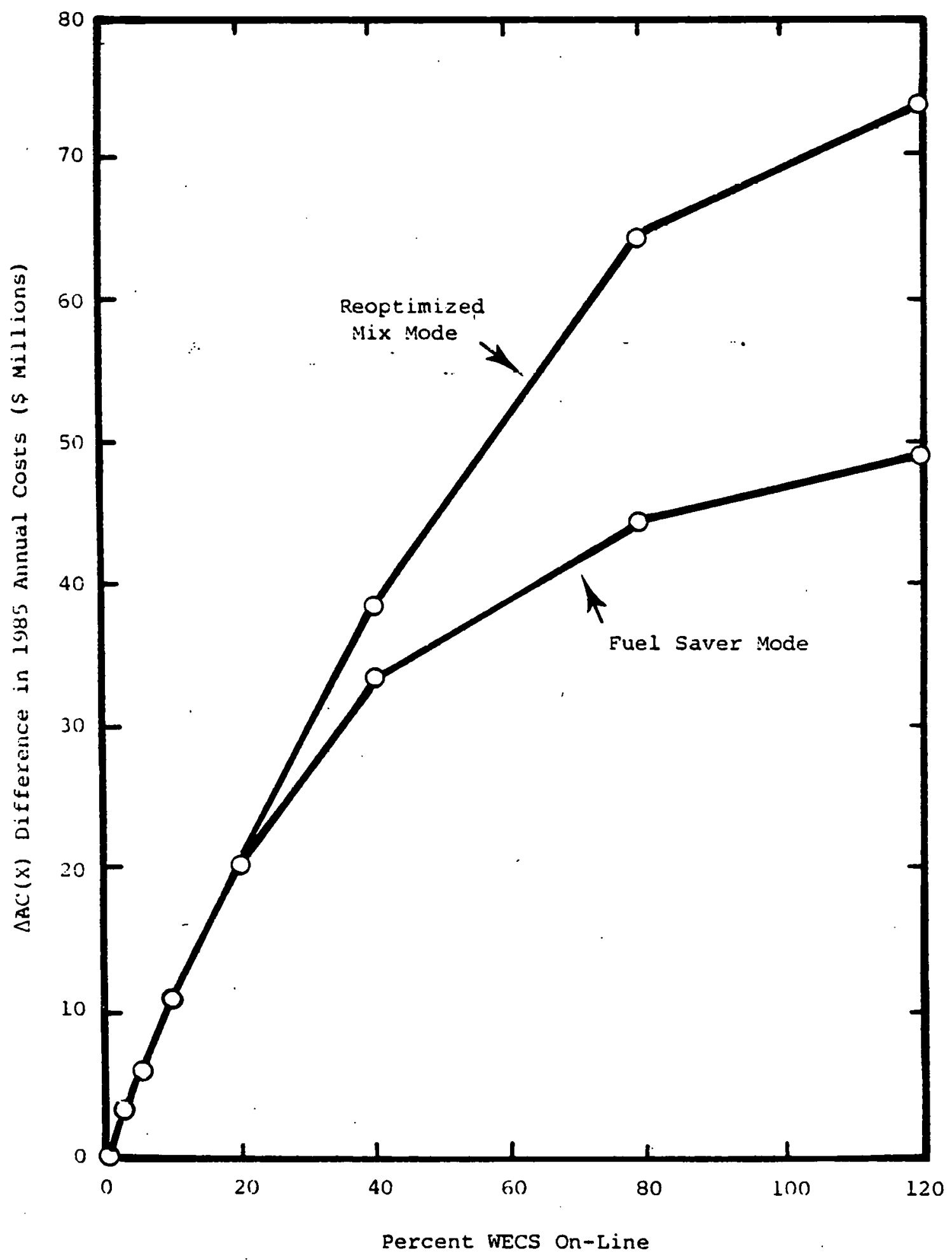

97 
of nuclear fuel prices produced but a \pm 28 variation in the difference in annual costs. 
NOTES $(1.3)$

1. JBF1, 5-17.

2. DEW, 58 .

3. SWRI, 128.

4. SWRI, 132.

5. JBF1, 5-28 (Figure 5-13).

6. JBF1, 5-29 (F1gure 5-14).

7. JBF1, 5-34 (Figure 5-16).

8. JBF1, 5-32 (Figure 5-15).

9. JBF1, 5-37. 


\subsection{SWECS LOLP Impact}

In order to insure a high probability of meeting anticipated demand, utilities maintain power-generating capacity beyond that required to satisfy the peak hourly load. This additional capacity, called reserve margin, furnishes the standby needed to provide an adequate standard of service. Some criteria must be used to evaluate system reliability and thereby serve as a basis for establishing the reserve margin. This criteria should take into account the stochastic nature of equipment failure (i.e., forced outages) and the variation in size and forced outage rates of the generating units.

One technique commonly used to evaluate the reliability of a generation system is the Loss of Load Probability (LOLP). DeWinkel provides the following description of Lorp: ${ }^{1}$

Historically, utility system planners measured generation system reliability with a percent reserves index. This planning design criterion simply measured the ratio of total installed generating capacity to the annual peak load demand. However, this approach proved to be a relatively insensitive indicator of system reliability, particularly when comparing alternative units whose size and forced outage rate very.

Today, the accepted measure of generation system reliability is the "Loss of Load Probability" index (LOLP). The LOLP technique is a probabilistic measurement of the expected number of days per year on which the available capacity cannot meet the load demand. The LOLP index provides a consistent and sensitive measure of generation system reliability although the name, loss of load probability, is misleading in two respects. First, the index is not a probability, it is an expected value of the number of days per year of capacity deficiency. Second, it is not a loss of load, but rather a deficiency of installed available capacity. Despite the misnomers, the LOLP approach is a well accepted approach in the utility industry today. (Garate 1977, Appendix G, p. 4-2)

The JBF study includes these comments: ${ }^{2}$

Although most utilities use the LOLP, the definition may vary. The basic building block of all of the variations of the LOLP is the calculation for a single hour. In the case of NEPOOL, 
who performs all loss of load probability calculations for the entire New. England Power Pool, an "Annual LOLP" is defined as the sum of the 260 single hour LOLP's which correspond to the hour of peak load during each weekday during the year.

By utility definition, a loss of load occurs when the load cannot be satisfied. (It does not include transmission line or substation failure.) This technique ignores the impact of a number of operational considerations that occur during power shortages (e.g., appeals to the public to reduce consumption, voltage reductions, etc.). The Loss of Load Probability expresses the statistical relationship between ability to meet the load, reserve margin, the forced outage rate (FOR), and the mainteriance schedule for each generating unit.

Addition of WECS capacity to a utility's generating mix results in

a lower LOLP. This occurs for two reasons:

(1) WEC power output, even though of a stochastic nature, reduces the need for conventional sources.

(2) The addition of WECS and mix reoptimization causes a change in optimum mix. The shift is toward more peaking capacity (low forced outage rate) and less baseload capacity (high forced outage rate).

These two factors account for the capacity credit that may be assigned to WECS. It should be kept in mind that the capacity credit that can be allocated to wECS is "a function of the impact wECS has on the conventional equipment that must be maintained by a utility to meet its reliability requirements." 3 WECS, by itself, has no inherent capacity credit.

The probability of generating various levels of power may be calculated from the probabilities of each piece of equipment in the mix being available. Equipment availability is, in turn, affected by maintenance scheduling and average forced outages. A curve may be constructed from the probabilities associated with particular levels of power being avallable (Figure 24 ). 4 
FIGURE 24. PROBABILITY OF AVAILABLE POWER

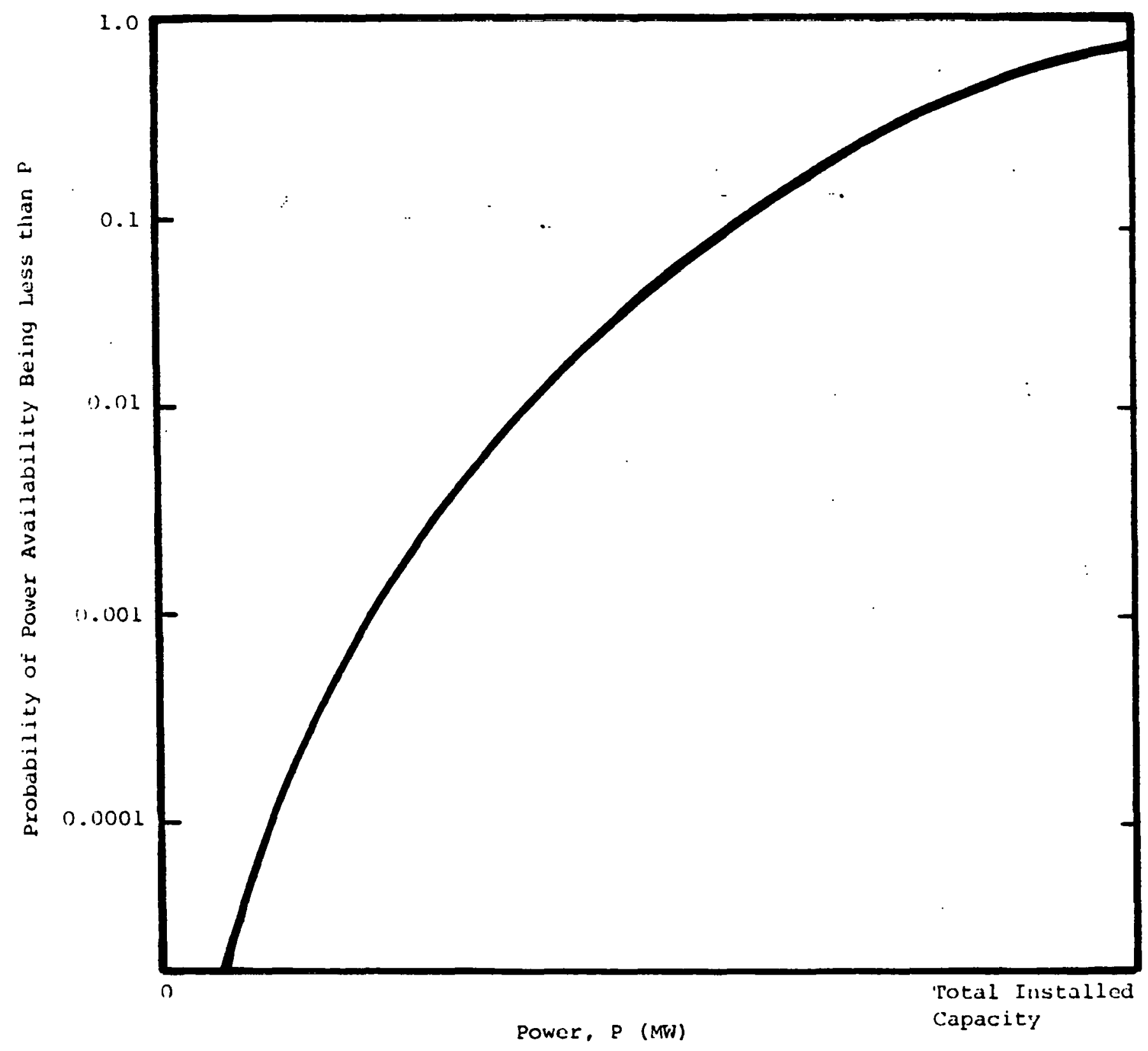


This 'Probability of Available Power' plot may then be used to evaluate the probability that a given hour's load will not be satisfied. By summing these hourly LoLP's (or a select set of them) over a year's time, an annual LoLP may be defined.

When wECS are included in the power and probability calculations, the forced outage rate and maintenance scheduling of wECs must also be accounted for. In the JBF study this was done by defining weCs availability and assuming that forced outages are evenly distributed over an array. ${ }^{5}$ WECS on-line, i.e., actually producing usable power, is defined as the product of WECS penetration (total installed WECS capacity) and an availability factor (0.9 for this study). 
NOTES (1.4)

1. DEW, 49: (Garate 1977, Appendix G. p. 4-2)

2. JBE1, 6-1 Mathematical calculations of hourly and annual LOLP for systems with and without WECS are included in Chapter 6 of this volume of the JBF study.

3. JBF1, 6-2.

4. JBF1, 6-4 (Figure 6-1).

5. JBE1, 6-7. 


\subsection{Impact on Operating Reserve}

Operating reserve is required for meeting fluctuations and uncertainties in the expected load. Daily estimations of reserve are usually based upon historical data on the expected load variation in the next 24 hours. The actual operating reserve put on-line may be modified by the dispatcher according to his estimation of next-day load requirements. There are no set rules or formulas for determining the practical level of operating reserves; it is largely a matter of judginent and experience.

Inclusion of WECS in a utility power grid brings about additional uncertainty due to errors in forecasting wind conditions for the next 24 hours. This uncertainty in WECS power output, when combined with the uncertainty in predicting the next-day load, results in a requirement for additional operating reserve as compared to the case with no wECS. The cost of providing this additional on-line capacity, called wECS operating reserve (WOR), must be charged against the value of the wECS.

The JBF study furnishes a procedure for determining wECs operating reserve: ${ }^{1}$

The method selected was to assume that present on-line operacing reserves are a direct function of the operator's ability to predict the next day's load. The errors associated with load forecasting are then statistically combined with the errors associated with predicting future wind power levels to obtain a composite or total uncertainty in predicting load requirements when wind power is added to the utility mix. The difference between the operating reserve required because of this total uncertainty in load prediction, and the without-weCs operating reserve required, was defined as the amount of additional operating reserve (WOR) required by the addition of WECS. 
The process is shown in Figure 25 , where: ${ }^{2}$

$$
\begin{aligned}
\sigma_{W}= & \text { Standard deviation (MW) of forecasted } \\
& \text { WECS power for a twelve hour period } \\
\sigma_{L}= & \text { Standard deviation (MW) of utility } \\
& \text { load forecasted } \\
\sigma_{T}= & \text { Effective total load error }=\left(\sigma_{W}^{2}+\sigma_{L}^{2}\right)^{\frac{1}{2}} \\
\sigma_{N}= & \text { Net error requiring additional operating } \\
& \text { reserve (WOR) due to WECS } \\
3 \sigma_{N}= & 3 \sigma_{T}-3 \sigma_{L}=\text { WOR }
\end{aligned}
$$

The WECS power forecasting technique adopted for the JBF study uses National Weather Service wind speed forecasts made by their Model output Statistics procedure. The error in 12-hour wind speed forecasts was found to have a fairly constant value of $2 \mathrm{~m} / \mathrm{s}$ for wind speeds between 4 and $8 \mathrm{~m} / \mathrm{s}$. This range corresponds to that of the effective cut-in and rated speed of the WECS array, respectively 1.4 and $8.9 \mathrm{~m} / \mathrm{s}$. Based on an array performance of :

$$
\text { Array Power }=(0.132 \mathrm{~V}-0.179) \mathrm{P}_{\mathrm{r}}
$$

where

$$
\begin{aligned}
& \text { Array Power is in } M W \\
& P_{C} \text { is rated power of array (MW) } \\
& V \text { is wind speed at } 10 \text { meter reference height }(\mathrm{m} / \mathrm{s})
\end{aligned}
$$

the $2 \mathrm{~m} / \mathrm{s}$ standard deviation in NWS forecast wind speed error translates into a $0.264 \mathrm{P}_{r}$ standard deviation of wECS array power forecast error. Thus, $\sigma_{W}=0.264 P_{I}$ (MW) for a twelve hour forecast period.

Forecast of the utility's next-day hourly load (through NEPOOI's NEPEX operations) historically has been accurate to within $\pm 3 \%$. This percentage corresponds to three standard deviations in forecasted load error, so that 


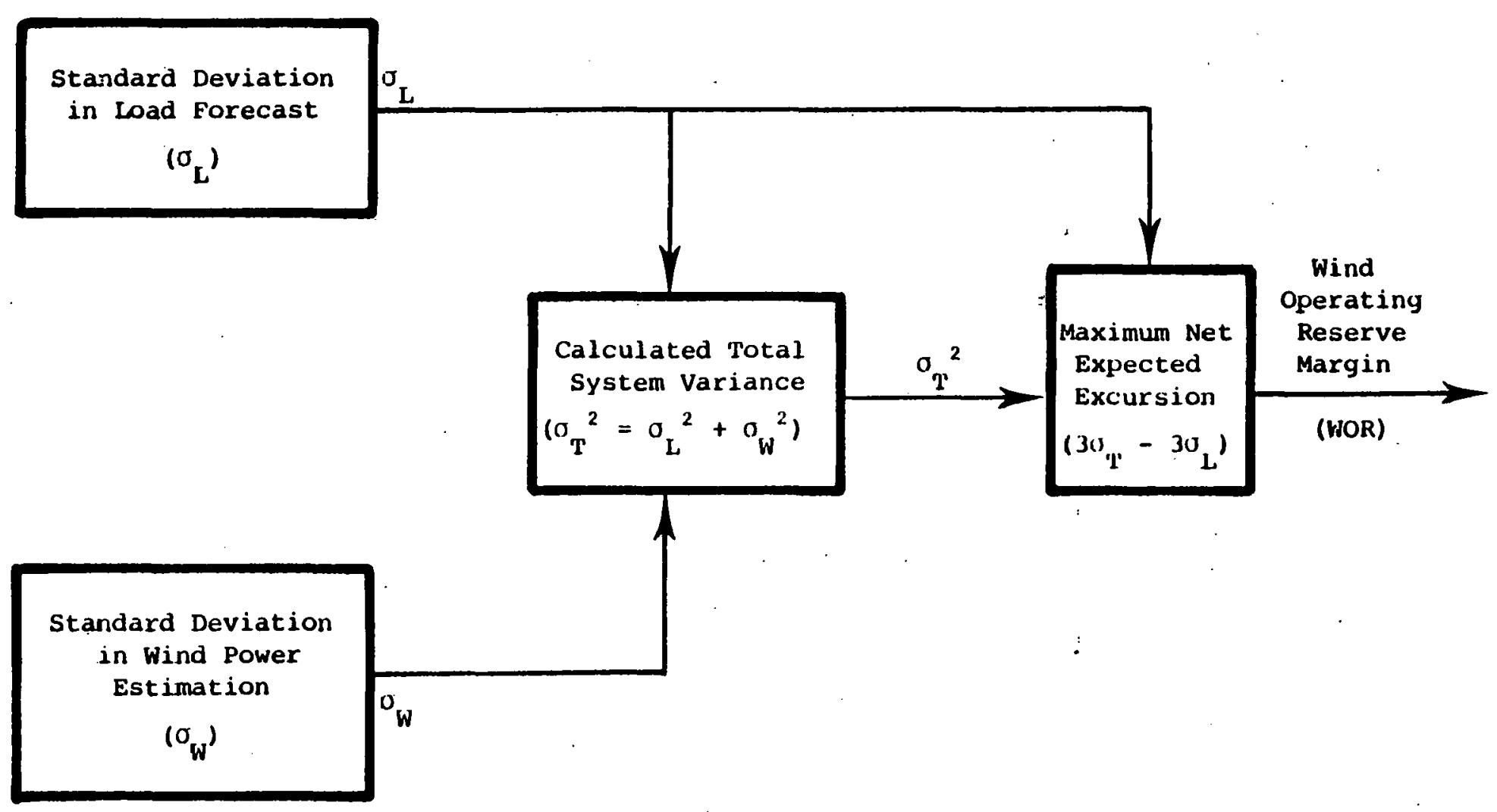


$3 \sigma_{L}=38$ of predicted load. Estimated average 1985 NEPOOL loads equals $14,000 \mathrm{MW}$, hence $\sigma_{\mathrm{T}}=140 \mathrm{IW}$.

The amount of WOR required for a given level of on-line WECS may now be calculated straightforwardly from the procedure shown in Figure 25 .

In determining the cost of providing the wECS operating reserve, the JBF study made the following assumptions: ${ }^{3}$

- The cost of providing WOR is assumed to be the average cost of fuel consumed by oil-fired steam units operating at idle with a capacity equal to the wor. (Idle rate $=1.02 \mathrm{MBtu} /$ hour/ rated $M W$ )

- WOR produces a cost that must be charged against WECS half the time. (The other half of the time woR is used to satisfy actual loads, the cost of which is recovered from the user and is not charged to wECS.)

Based upon these assumptions and an energy cost of $\$ 3.10 / \mathrm{MBtu}$, the annual cost of fuel per MW of WOR will be $\$ 13,850$.

The JBF calculations revealed that the wECS operating reserve cost increases faster than the rate of increase of weCs usage. 4 Doubling the amount of on-line WECS more than triples the WOR costs. 
NOTES (1.5)

1. JBFI, 7-2.

2. JBFI, 7-4 (Figure 7-1).

3. JBEl, 7-5.

4. JBE1, 7-7. 


\subsection{Capacity Credit}

WECS in a utility system are often evaluated only in terms of gross savings from the energy in the wind, which are primarily fuel savings. Although a major benefit of WECS accrues from the fuel savings, WECS also have the potential of reducing the required installed capacity of conventional generating equipment. To the extent that they can do this without compromising the reliability standards of the utility, WECS can be allocated a capacity credit.

Step (4) of the WECS utility evaluation presented in DeWinkel's report ${ }^{I}$ addresses the question of capacity credit for wECS. After noting that the addition of WECS to a utility system reduces the loss of load probability (LOLP), the procedure states:

The effective capacity of the WECS is the amount of additional peak load that the system could meet or the conventional capacity that could be omitted to bring the LoLP back to its original level. This effective capacity determines the capacity credit.

Since the Dairyland Power Cooperative does not perform its own separate system reliability assessment, DeWinkel does not include capacity credit evaluations in his study. ${ }^{2}$ However, he does provide estimates of capital cost savings when wECS plus load control replaces a peak-load generator, such as a combustion turbine. Net benefits of WECS (capital cost savings minus the cost of the controlled storage) are given by:

$$
\$ 135-\$ 37=\$ 98 \text { per } \mathrm{kW} \text { of WECS }
$$

Two of the systems considered were reputed to have a reliability comparable to that of combustion turbines.

The JBF study defines capacity credit in terms of reserve margin: "The amount that the utility reserve margin can be reduced after the installation 
of WECS while still maintaining the same reliability, is called the WECS capacity credit. This capacity credit represents fixed cost that the utility will not have to incur." ${ }^{3}$ The technique used for determining the capacity credit that can be assigned to WECS is "to reduce the capacity of installed conventional units until the utility with-WECS annual LOLP is equal to the without-WECS LOLP. The reduced capital investment associated with the eliminated conventional units is a benefit that is credited to WECS." 4 The utility's required LOLP, the reliability level that is used to determine the required reserve margin, is used as a target value to be maintained as WECS units are added to the equipment mix.

Calculation of WECS capacity credit for the NEGEA was facilitated by a graphical technique. For a given wECS level, peaking unit capacity was removed in significant chunks until the NEGEA required LOLP of 18.99 was exceeded. A graph of LOIP versus removed capacity was formed from the resulting data points. The point where the removed capacity crosses the LOLP $=18.99$ line gives the capacity credit that can be attributed to wECS. Figure 26 shows an example of this technique applied for a $40 \%$ on-line weCS level.

The amount of capacity credie that may be assigned to weCs varies as a function of on-line wecs level of the utility's load. Generally, more credited capacity is attributable to wECS for the reoptimized mix mode than for the fuel saver mode, although at low levels of WECS the difference is small. The difference is due to the additional fixed cost savings enjoyed by the reoptimized mix mode. For both modes it is true that the higher the level of on-line WECS, the lower the capacity credit that may be allocated to one more WECS. For large amounts of on-line WECS, the marginal capacity credit drops to below 108 . 
FIGURE 26. CREDITED CAPACITY OE 40\% ON-LINE WECS

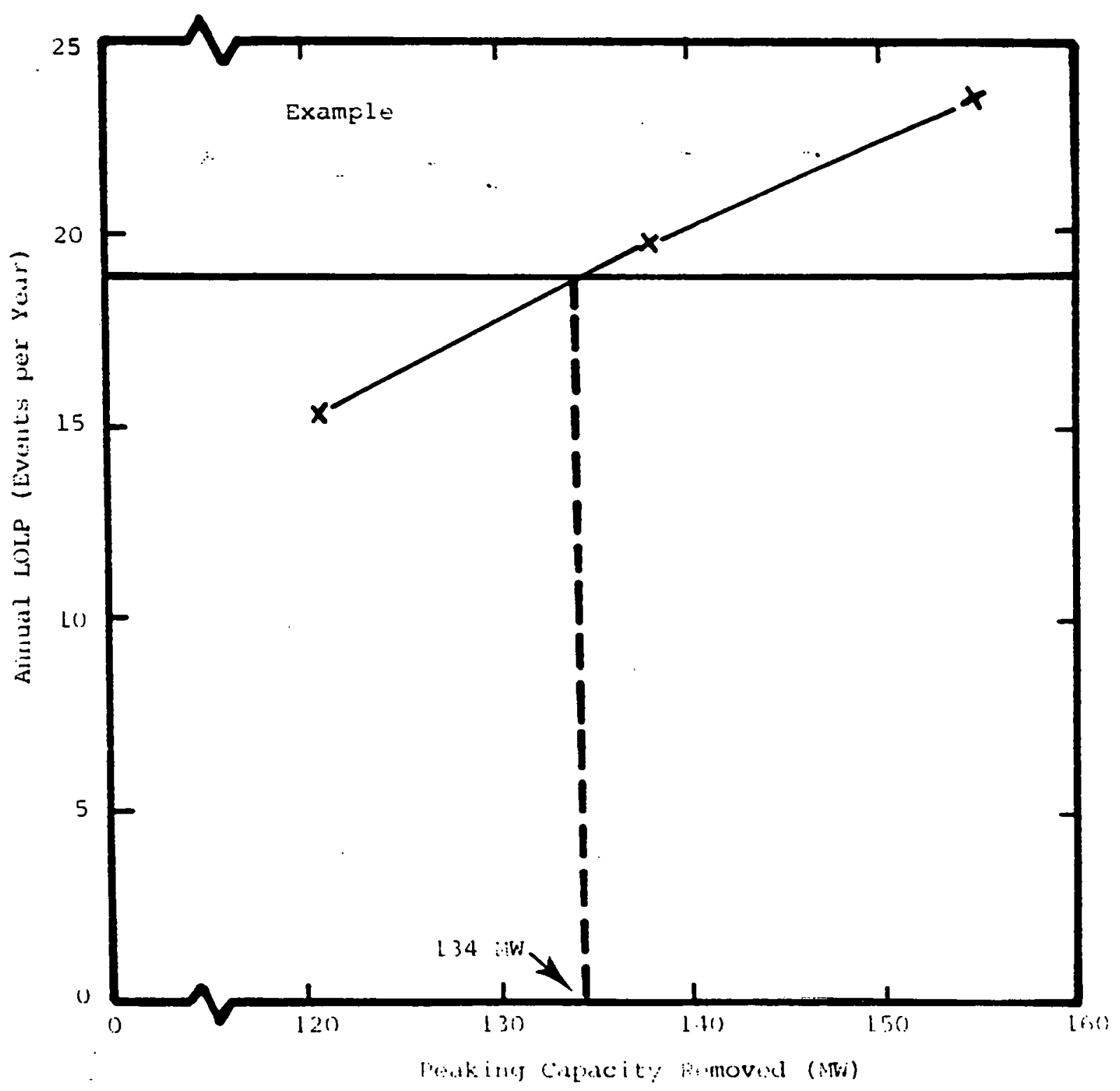

112 
Savings from WECS credited capacity arise from annual fixed cost savings resulting from the displacement of conventional peaking units. The JBF study assumed that NEGEA would be using gas turbines as peaking units. The levelized fixed cost of gas turbines in 1985 was estimated by NEGEA to be $\$ 60 / \mathrm{kW} /$ year.

Capacity credit calculations in the Southwest Research study are likewise based on an LOLP assessment of system reliability. The equivalent capacity of WECS is equated to the kilowatt rating of steam turbine generator capacity which gives the same LOLP as WECS, taking into account the forced outage rate of the steam turbines. 6 
NOTES (1:6)

1. DEW, 48-49: (Johnson and Goldenblatt 1977; Melton 1977; Marsh 1978).

2. DEW, 49.

3. JBFi, 6-1.

4. JBF1, 6-2.

5. JBF1, 6-23 (Figure 6-5).

6. SWRI, 144 . 
2. SWECS in "Analysis of a Specific Utility"

Public Service Indiana (PSI) was selected as a representative regional utility for this study. The incorporation of various amounts of WECS into its power grid will be examined. PSI is a major Indiana utility which currently serves the electric energy needs of more than a half-million homes, farms, factories, etc., in 69 of Indiana's 92 counties. $98 \%$ of the Company's electric power output is produced from coal. Nuclear power will help supply the energy needs of the PSI service area in the future.

PSI currently services about $75 \%$ of the geographical area of Indiana and operates nine generating facilities with a tenth under construction. The facility locations and capacities are shown in Figure 27. 


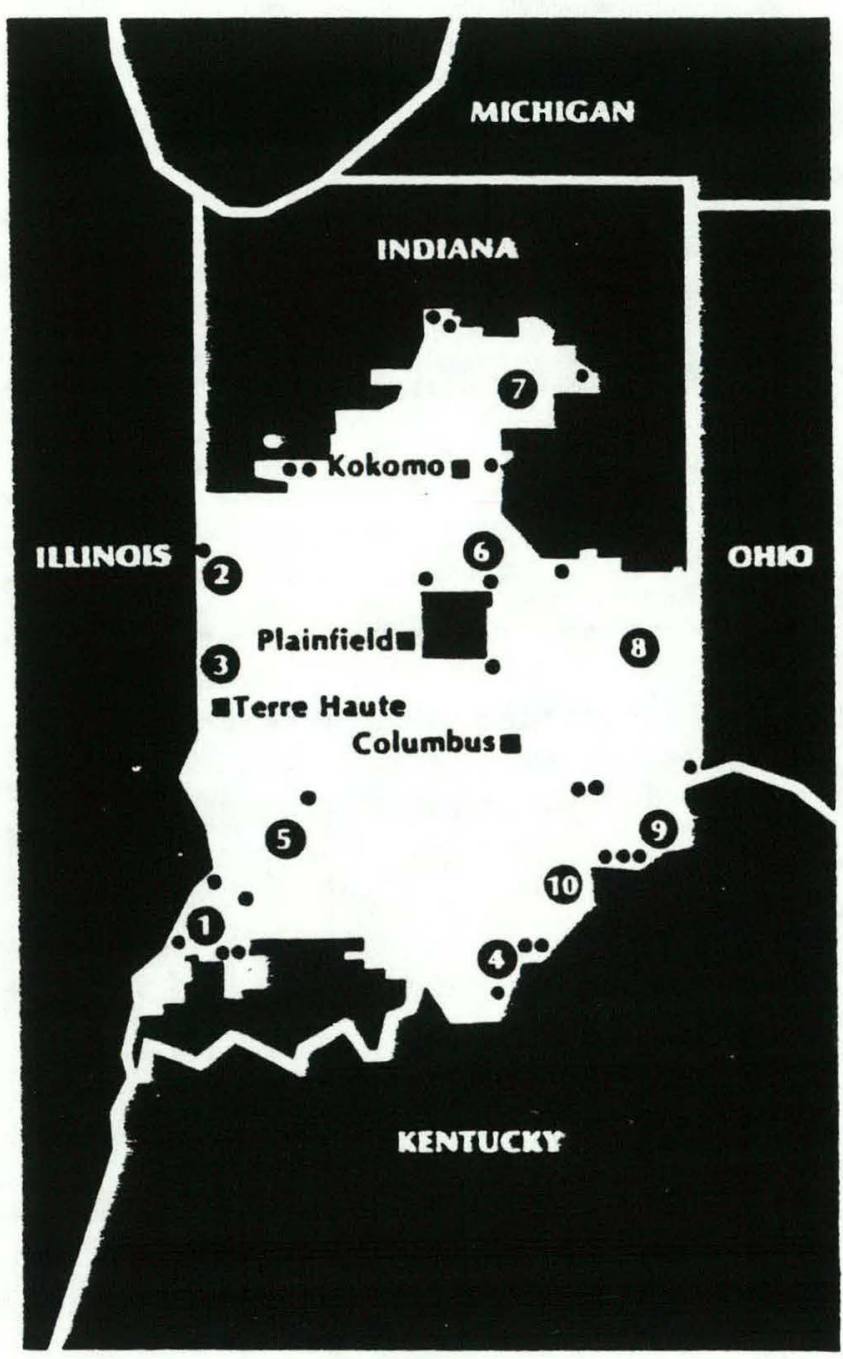

Power Generating Facilities:

1 Gibson Station

$1,950,000$ kilowatts (1,300,000 kilowatts under construction)

2 Cayuga Station

1.036.000 kilowatts

3 Wabash River Station 889,000 kilowatts

4 Gallagher Station

637,000 kilowatts

5 Edwardsport Station

165.000 kilowatts

6 Noblesville Station

106.000 kilowatts

7 Miami-Wabash Peaking Station 104,000 kilowatts

- Connersville Peaking Station 98.000 kilowatts

9 Markland Hydroelectric Station 81,000 kilowatts

10 Marble Hill Nuclear Station

$(2,260,000$ kilowatts under construction)

- Interconnection points with neighboring power systems for two way flow of energy to increase reliabili$t y$ and efficiency 


\subsection{Proposed Expansion Plan}

Public Service Indiana's annual demand and energy requirements, historical and forecast, are tabulated in Tables $13 \mathrm{a}$ and $13 \mathrm{~b}$ and illustrated in Figures 28 and 29. Peak loads are expected to grow at an annual rate of 3.88 through the year 2000 . The decreasing forecasted load factor is due to a lower anticipated base-load growth during this period. The historical valley to peak load ratio has a mean value of 0.325 with standard deviation of 0.015 . This ratjo is" not likely to change dramatically in the coming years. Winter peak loads are expected to exceed summer peaks due to increasing usage of domestic electric heating. The relationship of monthly peak loads to annual peak loads is presented in Table 14. PSI anticipates no additional capacity up to 1993. Alternatives are being considered for 1994 and beyond, but the results of these studies will not be available for some time. Units currently under construction (Gibson 5 and Marble Hill 1 and 2) will be operational in 1990, the first year in which the addition of WECS is being considered by this study. Under current plans, the coal-fired Gibson 5 unit will be completed in 1982 asid the Marble Hill nuclear units in 1986 and 1987. 
Table 13a. PSI ANNUAL DEMAND AND ENERGY REQUIREMENTS:

HISTORICAL, 1962-1980

HISTORICAL

\begin{tabular}{|c|c|c|c|c|c|c|c|c|}
\hline Year & Hours & $\begin{array}{l}\text { Peak } \\
\text { (MW) }\end{array}$ & $\begin{array}{l}\text { Change } \\
\text { in Peak }\end{array}$ & $\begin{array}{c}\text { Valley } \\
\text { (MW) }\end{array}$ & $\begin{array}{l}\text { Energy } \\
\text { (GWh) }\end{array}$ & $\begin{array}{c}\text { Load } \\
\text { Factor } \\
(8)\end{array}$ & $\begin{array}{c}\text { Valley/ } \\
\text { Peak }\end{array}$ & $\begin{array}{l}\text { Month } \\
\text { of } \\
\text { Peak } \\
\end{array}$ \\
\hline 1962 & 8,760 & 1,185 & -- & 372 & 6,497 & 62.6 & $\begin{array}{l}\prime \\
.314 \\
\end{array}$ & $D E C$ \\
\hline 1963 & 8,760 & 1,300 & 9.70 & 389 & 6,951 & 61.0 & .299 & $D E C$ \\
\hline 1964 & 8,784 & 1,364 & 4.92 & 406 & 7,533 & 62.9 & .298 & DEC \\
\hline 1965 & 8,760 & 1,481 & 8.53 & 462 & 8,182 & 65.3 & .323 & DEC \\
\hline 1966 & 8,760 & 1,565 & 5.67 & 526 & 9,025 & 65.8 & .336 & JUL \\
\hline 1967 & 8,760 & 1,671 & 6.77 & 550 & 9,652 & 65.9 & .329 & Nov \\
\hline 1968 & 8,784 & 1,933 & 15.70 & 617 & 10,832 & 63.8 & .319 & AUG \\
\hline 1969 & 8,760 & 2,083 & 7.76 & 730 & 11.831 & 64.8 & .350 & JUL \\
\hline 1970 & 8,760 & 2.173 & 4.32 & 753 & 12,393 & 65.1 & .347 & JAN \\
\hline 1971 & 8,760 & 2,372 & 9.16 & 796 & 12,971 & 62.4 & .336 & JUN \\
\hline 1972 & 8,784 & 2,514 & 5.99 & 818 & 13,789 & 62.5 & .325 & AUG \\
\hline 1973 & 8,760 & 2,740 & 8.99 & 871 & 14,530 & 60.5 & .318 & AUG \\
\hline 1974 & 8,760 & 2,666 & -2.70 & 909 & 14,691 & 62.9 & .341 & JUL \\
\hline 1975 & 8,760 & 2,873 & 7.76 & 878 & 15,379 & 61.1 & .306 & AUG \\
\hline 1976 & 8,784 & 2,928 & 1.91 & 925 & 16,479 & 64.1 & .316 & NoV \\
\hline 1977 & 8,760 & 3,230 & 10.30 & 1,073 & 17,904 & 63.3 & .322 & JUL \\
\hline 1978 & 8,760 & 3,426 & 6.07 & $1,1.12$ & 18,009 & 60.0 & .325 & JAN \\
\hline 1979 & 8,760 & 3,488 & 1.81 & 1,187 & 19,046 & 62.2 & .340 & JAN \\
\hline $1980 *$ & 8,784 & 3,364 & -3.56 & 1,087 & 8,184 & 27.7 & .323 & EEB \\
\hline
\end{tabular}


Table 13b. PSI ANNUAL DEMAND AND ENERGY REQUIREMENTS:

FORECAST, 1981-2000

FORECAST

\begin{tabular}{|c|c|c|c|c|c|c|c|c|}
\hline Year & Hours & $\begin{array}{l}\text { Annual } \\
\text { Peak } \\
\text { (MW) }\end{array}$ & $\begin{array}{l}\text { Change } \\
\text { in Peak } \\
(8)\end{array}$ & $\begin{array}{l}\text { MMPt } \\
\text { (MW) }\end{array}$ & $\begin{array}{c}\text { Energy } \\
(G W h)\end{array}$ & $\begin{array}{l}\text { Load } \\
\text { Factor } \\
(3)\end{array}$ & $\begin{array}{l}\text { AP/ } \\
\text { MMP' }\end{array}$ & $\begin{array}{l}\text { Month } \\
\text { of Peak }\end{array}$ \\
\hline 1981 & 8,760 & 3,827 & -- & 2,923 & 19,767 & 59.0 & .764 & JAN \\
\hline 1982 & 8,760 & 4,011 & 4.81 . & 3,031 & 20,653 & 58.8 & .756 & JAN \\
\hline 1983 & 8,760 & 4,218 & 5.16 & 3,143 & 21,367 & 57.8 & .745 & JAN \\
\hline 1984 & 8,784 & 4,420 & 4.79 & 3,258 & 22,014 & 56.7 & .737 & JAN \\
\hline 1985 & 8,760 & 4,620 & 4.52 & 3,371 & 22,887 & 56.6 & .730 & JAN \\
\hline $1986^{\circ}$ & 8,760 & 4,813 & 4.18 & 3,496 & 23,857 & 56.6 & .726 & JAN \\
\hline 1987 & 8,760 & 5,037 & 4.65 & 3,618 & 24,800 & 56.2 & .718 & JAN \\
\hline 1988 & 8,784 & 5,249 & 4.21 & 3,736 & 25,594 & 55.5 & .712 & JAN \\
\hline 1989 & 8,760 & 5,451 & 3.85 & 3,855 & 26,362 & 55.2 & .707 & JAN \\
\hline 1990 & 8,760 & 5,665 & 3.93 & 3,990 & 27,287 & 55.0 & .704 & JAN \\
\hline 1991 & 8,760 & 5,886 & 3.90 & 4,122 & 28,200 & 54.7 & .700 & JAN \\
\hline 1992 & 8,784 & 6,107 & 3.75 & 4,197 & 29,025 & 54.1 & .687 & JAN \\
\hline 1993 & 8,760 & 6,350 & 3.98 & 4,312 & 29,831 & 53.6 & .679 & JAN \\
\hline 1994 & 8,760 & 6,550 & 3.15 & 4,466 & 30,584 & 53.3 & .682 & JAN \\
\hline 1995 & 8,760 & 6,750 & 3.05 & 4,760 & 31,390 & 53.1 & .705 & JAN \\
\hline 1996 & 8,784 & 6,950 & 2.96 & 4,920 & 32,196 & 52.7 & .708 & JAN \\
\hline 1997 & 8,760 & 7.150 & 2.88 & 5,040 & 32,949 & 52.6 & .705 & JAN \\
\hline 1998 & 8,760 & 7,350 & 2.80 & 5,160 & 33,755 & 52.4 & .702 & JAN \\
\hline 1999 & 8,760 & 7,550 & 2.72 & 5,280 & 34,508 & 52.2 & .699 & JAN \\
\hline 2000 & 8,784 & 7,750 & 2.65 & 5,400 & 35,314 & 51.9 & .697 & JAN \\
\hline
\end{tabular}

3.78

tMMP $=$ Minimum Monthly Peak; AP/MMP = Annual Peak/MMP. 
FIGURE 28. PSI PEAK LOAD, HISTORICAL AND FORECAST

(EVEN YEARS PLOTTED)

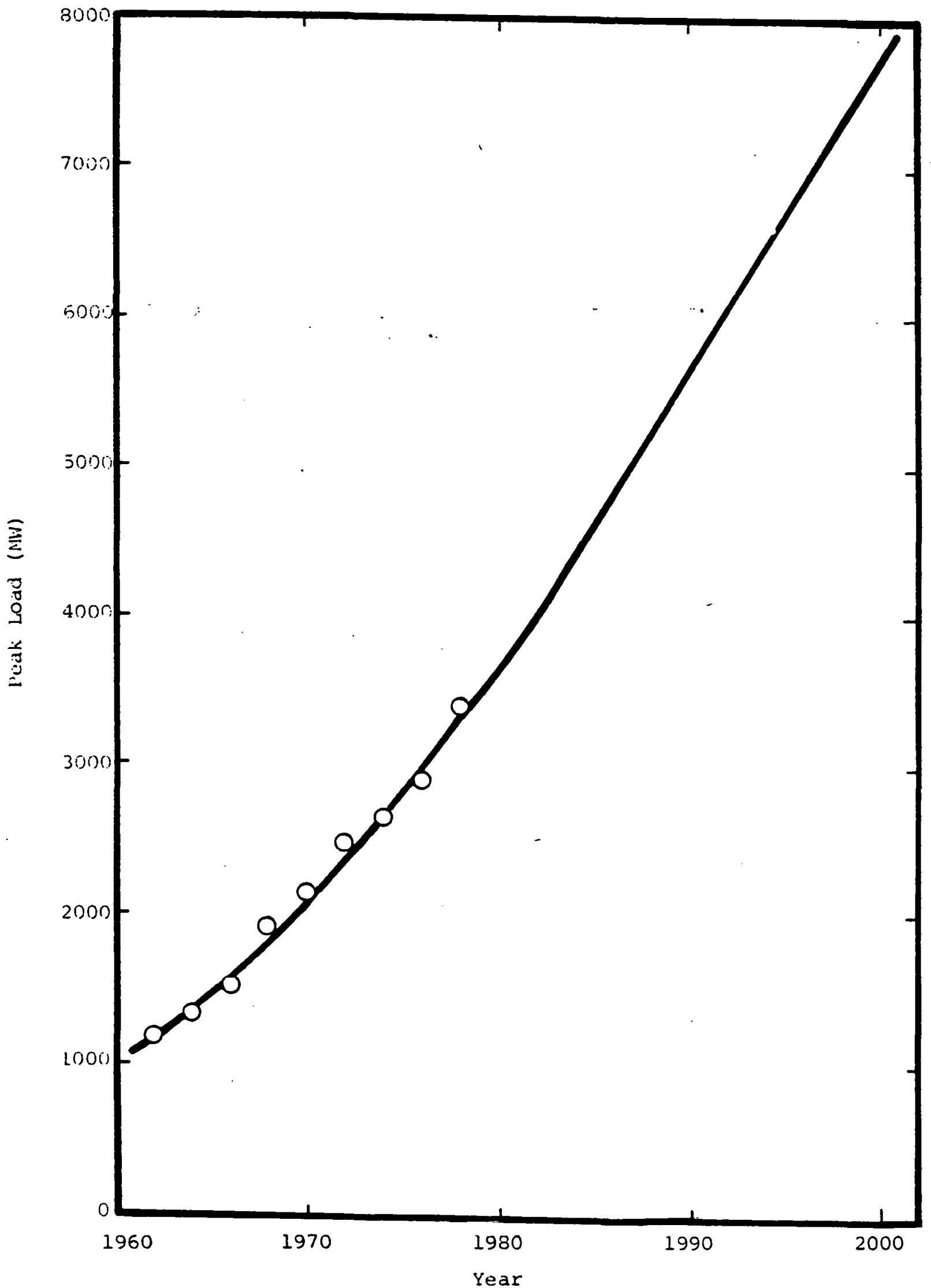


FIGURE 29. PSI ANNUAI ENERGY USAGE, HISTORICAL AND FORECAST (EVEN YEARS PLOTTED)

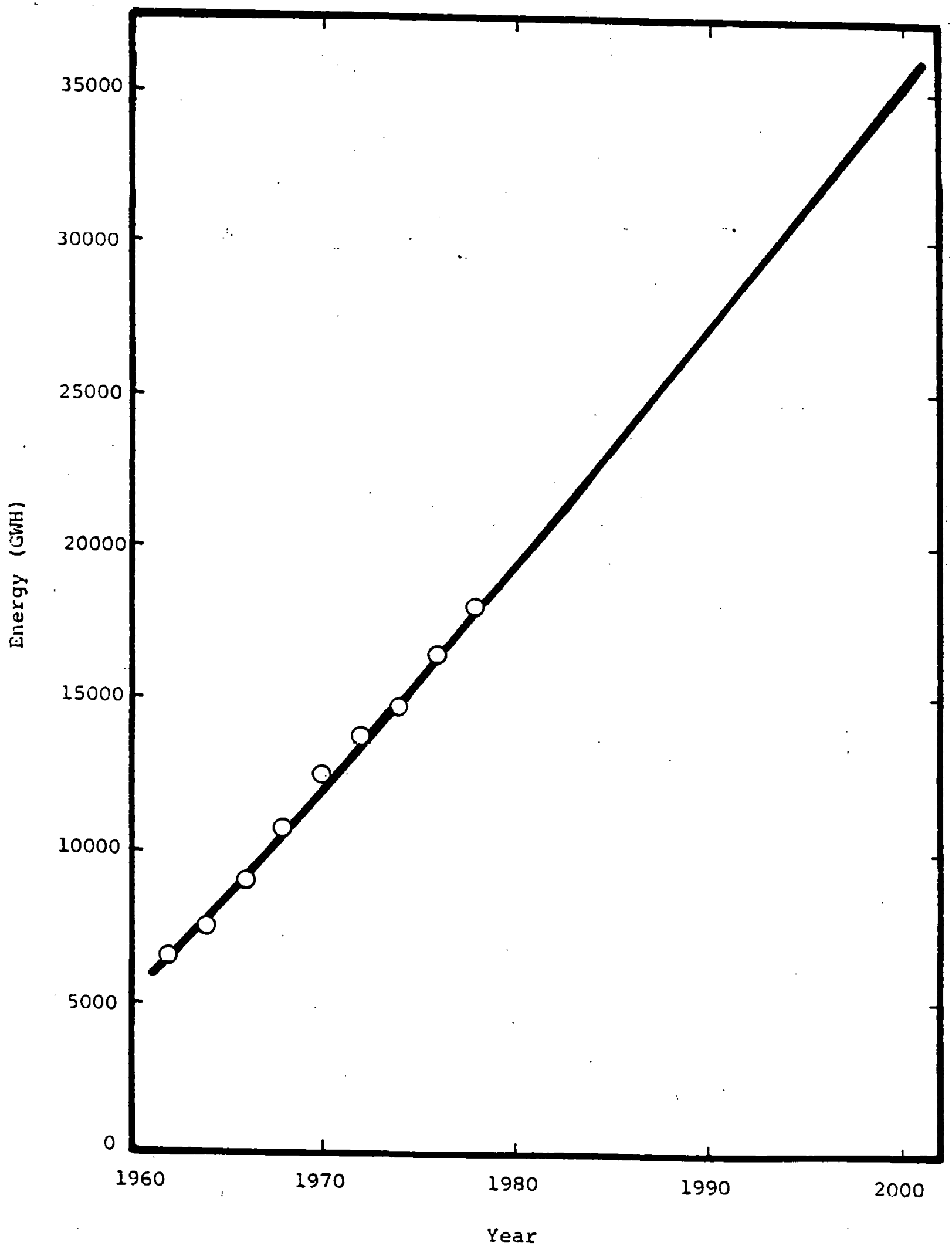


Table 14. RELATIONSHIP OF MONTHLY PEAK LOADS

TO THE ANNUAL PEAK LOAD. (PUBLIC SERVICE INDIANA)

Fraction of Annual Peak Load

Month
January
February
March
April
May
June
July
August
September
October
November

*Historical 


\subsection{Proposed Expansion Plan and WECS}

\subsubsection{Methodology}

This study's evaluation of the application of WECS to a regional utility, represented by Public Service Indiana, follows Dewinkel's analysis of the application of WECS to the Dairyland Power Cooperative. The major components of DeWinkel's analysis are displayed in Figure $15 .^{1}$ Computer programs developed by JBF were employed to carry out this analysis. ${ }^{2}$ Appendix contains brief descriptions of these programs. In addition, a busbar analysis will be applied to evaluate the use of WECS in an electric utility. Busbar costs are comonly used in the electric utility industry to compare generating alternatives. 
NOTES $(2,2.1)$

1. DEW, 64 (Figure 17).

2. JBF2. Volume 2 of the JBF report contains documentation and listings of each of the computer programs. 


\subsection{Proposed Expansion Plan and WECS}

\subsubsection{Data Assumptions}

of the six airport stations examined in section 1.1.8, Indianapolis was selected as a representative site for the PSI service region. Its average annual wind speed is near the mean value for the six sites. Furthermore, Indianapolis is situated at the lower edge of the northern half of the PSI service region, the area for which WECS installations appear to be most promising.

The three wind machines selected for the study are described in section 1.1.9. The manufacturer and models are: NASA/DOE MOD-O (100KW), NASA/DOE MOD-OA (200KW), and the Millville 100KW. Of these, the Millville 100kw was selected as a representative machine for detailed study because it is being commercially manufactured.

Seven levels of installed WECS capacity shall be considered: 0,20 , $40,80,160,320$, and $480 \mathrm{MW}$. This spread corresponds to a range of approximately 0-68 of PSI's installed capacity in 1990. These values reflect a moderate approach on the part of a regional utility to the incorporation of wind turbines into its power grid. Since the low levels of WECS penetration will not significantly affect the conventional equipment mix, the reoptimized mix mode described in the JBF report will not be considered in this study.

The 'analysis year' is the first year of operation for prospective WECS installations. For this study, 1990 was chosen as the analysis year. Public Service Indiana's 1990 conventional equipment mix shall represent the mix of a regional utility. It is described in Table 15 . Figure 30 details the calculation of "equivalent fuel cost". The breakdown of the mix according 
Table 15.

PSI CONVENTIONAL EQUIPMENT MIX, YEAR 1990

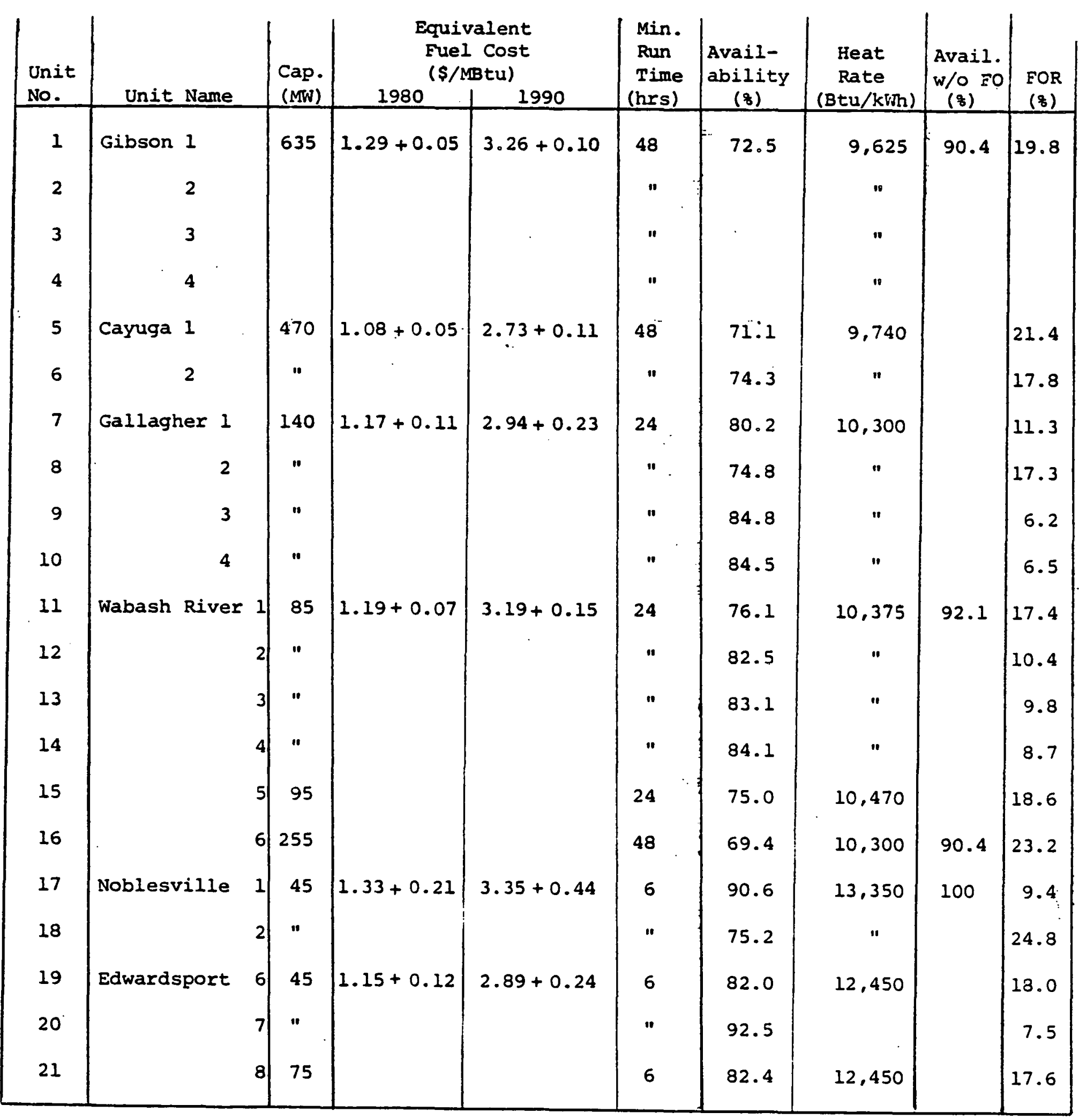

(continued) 
PSI CONVENTIONAL EQUIPMENT MIX, YEAR 1990 (CONTINUED)

\begin{tabular}{|c|c|c|c|c|c|c|c|c|c|c|}
\hline $\begin{array}{l}\text { Unit } \\
\text { No. }\end{array}$ & Unit Name & & $\begin{array}{l}\text { Cap. } \\
\text { (MW) }\end{array}$ & $\begin{array}{l}\text { Equiv } \\
\text { Fuel } \\
(\$ / M \\
1980^{(\$ M} \\
\end{array}$ & $\begin{array}{l}\text { alent } \\
\text { Cost } \\
\text { Btu) } \\
\quad 1990 \\
\end{array}$ & $\begin{array}{l}\text { Min. } \\
\text { Run } \\
\text { Time } \\
\text { (hrs) }\end{array}$ & $\begin{array}{c}\text { Avail. } \\
\text { ability } \\
(8)\end{array}$ & $\begin{array}{c}\text { Heat } \\
\text { Rate } \\
\left(B t u / k^{r} \cdot h\right) \\
\end{array}$ & $\begin{array}{l}\text { Avail. } \\
\text { w/O FO } \\
(8)\end{array}$ & $\begin{array}{l}\text { FOR } \\
(8)\end{array}$ \\
\hline 22 & Miami Mabash & 1 & 17 & $6.55+0.64$ & $19.80+1.16$ & 0 & 83.2 & 17,125 & 97.9 & 15.0 \\
\hline 23 & & 2 & $"$ & & & $"$ & & $"$ & & \\
\hline 24 & & 3 & $"$ & & & $"$ & & $"$ & & \\
\hline 25 & & 4 & $"$ & & & $"$ & & $"$ & & \\
\hline 26 & & 5 & 18 & & & 0 & & 17,125 & & \\
\hline 27 & & 6 & $"$ & & $\bullet$ & $"$ & & $"$ & & \\
\hline 28 & Connersville & 1 & 49 & $6.75+0.80$ & $20.42+1.68$ & 0 & 81.5 & 13,628 & 15.8 & 15.0 \\
\hline 29 & & 2 & " & & & $"$ & & $"$ & & \\
\hline 30 & Wabash River & $I \cdot C$. & 8 & $6.70+1.02$ & $20.25+2.14$ & 0 & 85.0 & 10,710 & 100 & 15.0 \\
\hline 31 & Cayuga DSL. & & 11 & $6.70+1.08$ & $20.25+2.27$ & 0 & 85.0 & 10,067 & & 15.0 \\
\hline 32 & Gibson 5 & & 625 & $1.29+0.25$ & $3.26+0.52$ & 48 & 70.5 & 9,900 & 90.4 & 22.0 \\
\hline 33 & Marble Hill & 1. & 1017 & $x . x x+0.06$ & $1.35+0.14$ & 96 & 70.0 & 10,500 & 83.3 & 16.0 \\
\hline 34 & & 2 & $"$ & $\mathbf{x} . \mathbf{x x}+0.06$ & $1.36+0.14$ & $"$ & 70.0 & $"$ & & \\
\hline
\end{tabular}

NOTES :

(1) Abbreviations:

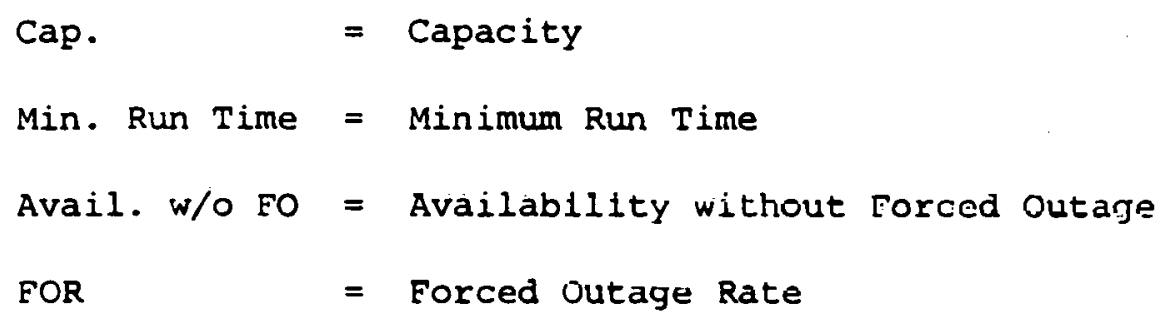

(2) The equivalent Fuel cost is the sum of the fuel cost and the incremental (variable) O\&M cost. Values are expressed in current dollars.

(3) The Availability without Forced Outage takes into account only scheduled maintenance. 
FIGURE 30. CAICULATION OF "EQUIVAIENT FUEL COSTS"

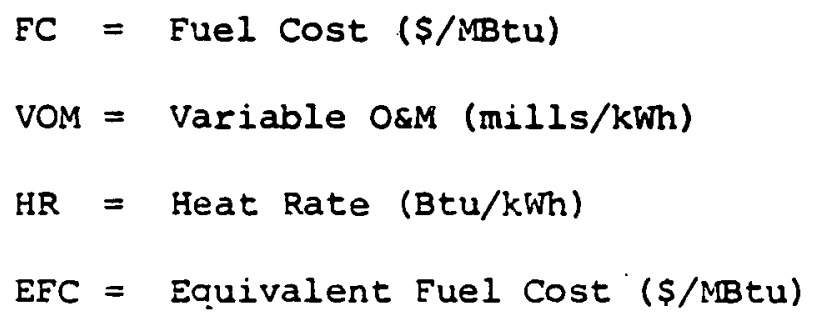

Example:

$$
\begin{aligned}
& \text { Miami Wabash } 1 \\
& \text { EC }=6.55 \quad \text { VOM }=10.90 \quad \text { HR }=17125 \\
& \text { EFC }=6.55+\frac{10.90}{\left(\frac{17125}{1000}\right)}=6.55+.64=7.19\left[\frac{\$}{\text { M.Btu }}\right]
\end{aligned}
$$


to load category and fuel type is presented in Table 16. The average effective on-line capacity of the system amounts to 5765 NW. Total installed capacity is 7865 MW.

For the purposes of the JBF generation planning and assessment programs, the Minimum Run 'Time (MRT) of each of the generating units had to be redefined (Table 17). The JBF programs assume an MRT based on a 24-hour cycle. Units which are expected to operate all the time (100\% base-loaded) are assigned a null MRT. A unit must be exercised at least one hour, so that the smallest non-zero MRT equals 1 . Units are dispatched only if they can be exercised at least as long as their minimum run time. After a fair amount of experimentation, a set of ranges of equivalent diurnal MRT's were determined for each PSI MRT, such that the annual usage of each of the generating units corresponds roughly to the observed present-day usage of the units. Three values of diurnal MRT define the ranges: a nominal value which represents typical use of the unit, a value to encourage use of the unit, and a value to discourage use of the unit. This last value corresponds to a penalty factor applied to the dispatching algorithm to discourage use of, for example, an older unit nearing retirement. On the other hand, use of a newly-built unit may be encouraged by reducing its equivalent diurnal MRT. 
Table 16.

PSI CONVENTIONAL EQUIPMENT MIX CATEGORIZED

BY LOAD TYPE, YEAR 1990

- Base-Loaded Units

\begin{tabular}{c|c|c|c|c} 
& Fuel & Capacity & Availability & $\begin{array}{l}\text { Effective } \\
\text { Capacity }\end{array}$ \\
\hline Marble Hill 1-2 & $\dot{\mathrm{N}}$ & 2034 & .700 & \\
Gibson 1-5 & $\mathrm{C}$ & 3165 & .721 & \\
Cayuga 1-2 & $\mathrm{C}$ & 940 & .727 & \\
Wabash River 6 & $\mathrm{C}$ & 255 & .694 & \\
\hline \multicolumn{2}{r|}{10 units } & 6394 & .714 & 4566
\end{tabular}

- Intermediate Units

\begin{tabular}{r|c|c|c|c} 
& Fuel & Capacity & Availability & $\begin{array}{l}\text { Effective } \\
\text { Capacity }\end{array}$ \\
\hline Gallagher 1-4 & $\mathrm{C}$ & 560 & .811 & \\
Wabash River 1-5 & $\mathrm{C}$ & 435 & .800 & \\
\hline 9 units & 995 & .806 & 802 \\
mean & 110.6 & &
\end{tabular}


Table 16.

PSI CONVENTIONAL EQUIPMENT MIX CATEGORIZED

BY LOAD TYPE, YEAR 1990 (CONTINUED)

- Peaking Units

\begin{tabular}{l|c|c|c|c} 
& Fuel & Capacity & Availability & $\begin{array}{l}\text { Effective } \\
\text { Capacity }\end{array}$ \\
\hline Noblesville 1-2 & C & 90 & .829 & \\
Edwardsport 6-8 & C & 165 & .850 & \\
Miami Wabash 1-6 & P & 104 & .832 & \\
Connersville 1-2 & P & 98 & .815 & \\
Wabash River I.C. & P & 8 & .850 & \\
Cayuga DSL. & P & 11 & .850 & \\
\hline 15 units & 476 & .835 & 397 \\
mean & 31.73 & &
\end{tabular}

- Total

\begin{tabular}{c|c|c|c|c|c} 
& $\begin{array}{l}\# \\
\text { Units }\end{array}$ & Capacity & Availability & $\begin{array}{c}\text { Effective } \\
\text { Capacity }\end{array}$ & $\begin{array}{c}\text { Average } \\
\text { Unit } \\
\text { Capacity }\end{array}$ \\
\hline Base-Loaded & 10 & 6394 & .714 & 4566 & 639.40 \\
Intermediate & 9 & 995 & .806 & 802 & 110.60 \\
Peaking & 15 & 476 & .835 & 397 & 31.73 \\
\hline TOTAL & 34 & 7865 & .733 & 5765 &
\end{tabular}

Fuel Types:

N - Nuclear

C - Coal

P - Petroleun 
Table 17. EQUIVALENT DIURNAL MINIMUM RUN TIMES FOR THE GENERATING UNITS OF THE REGIONAL UTILITY

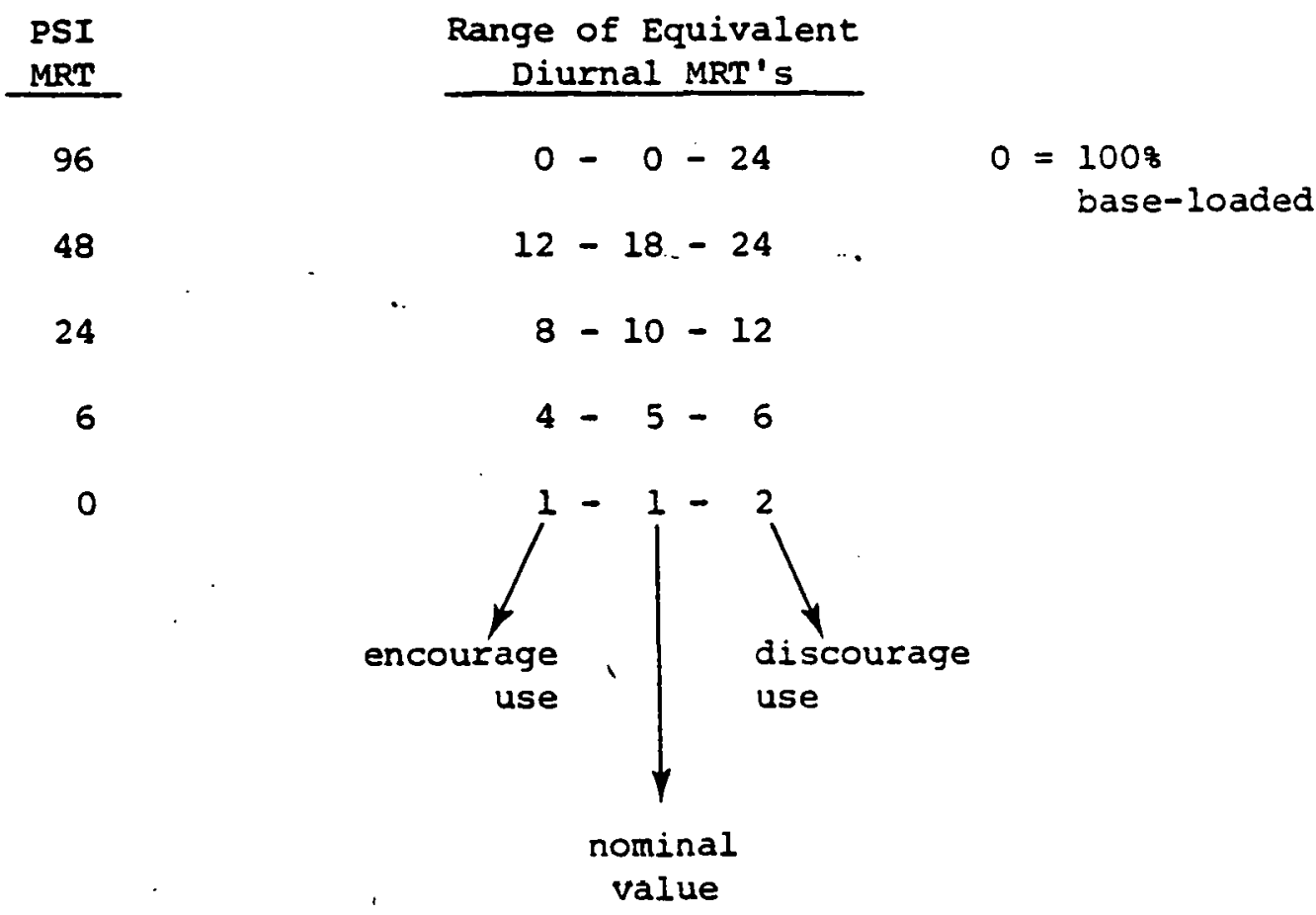




\subsection{Proposed Expansion Plan and WECS}

\subsubsection{WECS Operating Reserve}

Calculations of WECS Operating Reserve (WCR) follow the methodology prescribed in section 1.5. The Millville l00KW was selected as a representative machine, and it is assumed to operate in a wind regime like that of Indianapolis.

Assumptions:

- Standard deviation of forecast exror for winds between

4 and $8 \mathrm{~m} / \mathrm{s}$ is $2 \mathrm{~m} / \mathrm{s}$ (See JBF $1,7-3$ )

- WECS array performance (Millville 100KW WECS; Indianapolis

as representative site) is:

$$
\begin{aligned}
\text { Array Power } & =(1.18(\mathrm{~V} / 11.17)+(-.4201))^{P_{r}} \\
& =(0.106 \mathrm{~V}-.420) \mathrm{P}_{r}
\end{aligned}
$$

where

Array Power is in MW

$P_{r}$ is the rated power of the array (MN)

$\mathrm{V}$ is the wind speed at 10 meter reference height $(\mathrm{m} / \mathrm{s})$

- Standard deviation of forecasted load is 18 of predicted average load.

- The additional operating reserve necessitated by WECS will be furnished by cual-fired steam units running at idle. Since WOR is used to satisfy actual loads part of the time (which charges are recovered from the user), it is assumed that wOR fuel costs w1ll be charged to WECS half the time. 
Fuel Cost (Coal + Variable o\&M) $=\$ 3.50 / \mathrm{MBtu}$ (1990\$)
Heat Rate (Normal Operation) $=10,000 \mathrm{Btu} / \mathrm{kWh}$
Heat Rate (Idle) $=1.5 \mathrm{MBtu} /$ hour $/$ rated MW
Annual Operation Time $=4380$ hours
Heat Content of Coal $=10,800 \mathrm{Btu} / 1 \mathrm{~b} ; 21.6 \mathrm{MBtu} /$ ton

Annual Cost of Fuel = Heat Rate (Idle)

$x$ Fuel Cost $x$ Time

$=1.5$ (MBtu/hour/MW) $\times 3.50$ (\$/NBtu)

x 4380 (hours/year)

$=23,000(\$ / \mathrm{MW} /$ year $) \quad(1990 \$)$

Annual Energy Usage $=1.5$ (MBtu/hour $/ \mathrm{MW})$

x 4380 (hours $/$ year) $=6570 \mathrm{:BtU} / \mathrm{AW} /$ year

Annual Coal Consumption $=6570($ MBtu $/ \mathrm{MW} /$ year $) /(21.6 \mathrm{MBtu} /$ ton $)$

$=304.17$ tons $/ \mathrm{MW} /$ year

Since power is related to wind speed by a factor of 0.106 , the $2 \mathrm{~m} / \mathrm{s}$ standard deviation of forecast error results in a standard deviation of WECS array power forecast error of $0.212 \mathrm{P}_{r}$ in megawatts.

$$
\sigma_{W}=0.212 P_{r} \quad\left(3 \sigma_{W}=0.636 P_{r}\right)
$$

The predicted average load for PSI in 1990 is $4878 \mathrm{MW}$.

$$
\sigma_{L}=48.78 \quad\left(3 \sigma_{L}=146 \mathrm{MW}\right)
$$

The effective total load error is given by:

$$
\begin{gathered}
\sigma_{T}=\left(\sigma_{W}{ }^{2}+\sigma_{L}{ }^{2}\right)^{\frac{1}{2}} \\
{\left[3 \sigma_{T}=\left(\left(3 \sigma_{W}\right)^{2}+\left(3 \sigma_{L}\right)^{2}\right)^{\frac{1}{2}}\right]}
\end{gathered}
$$


The net error requiring additional wOR is given by:

$$
3 \sigma_{\mathrm{N}}=3 \sigma_{\mathrm{T}}-3 \sigma_{\mathrm{L}}
$$

WECS operating reserve requirements are tabulated in Table 18 for various levels of on-line WECS capacity. 
Table 18. WECS OPERATING RESERVE REQUIREMENTS

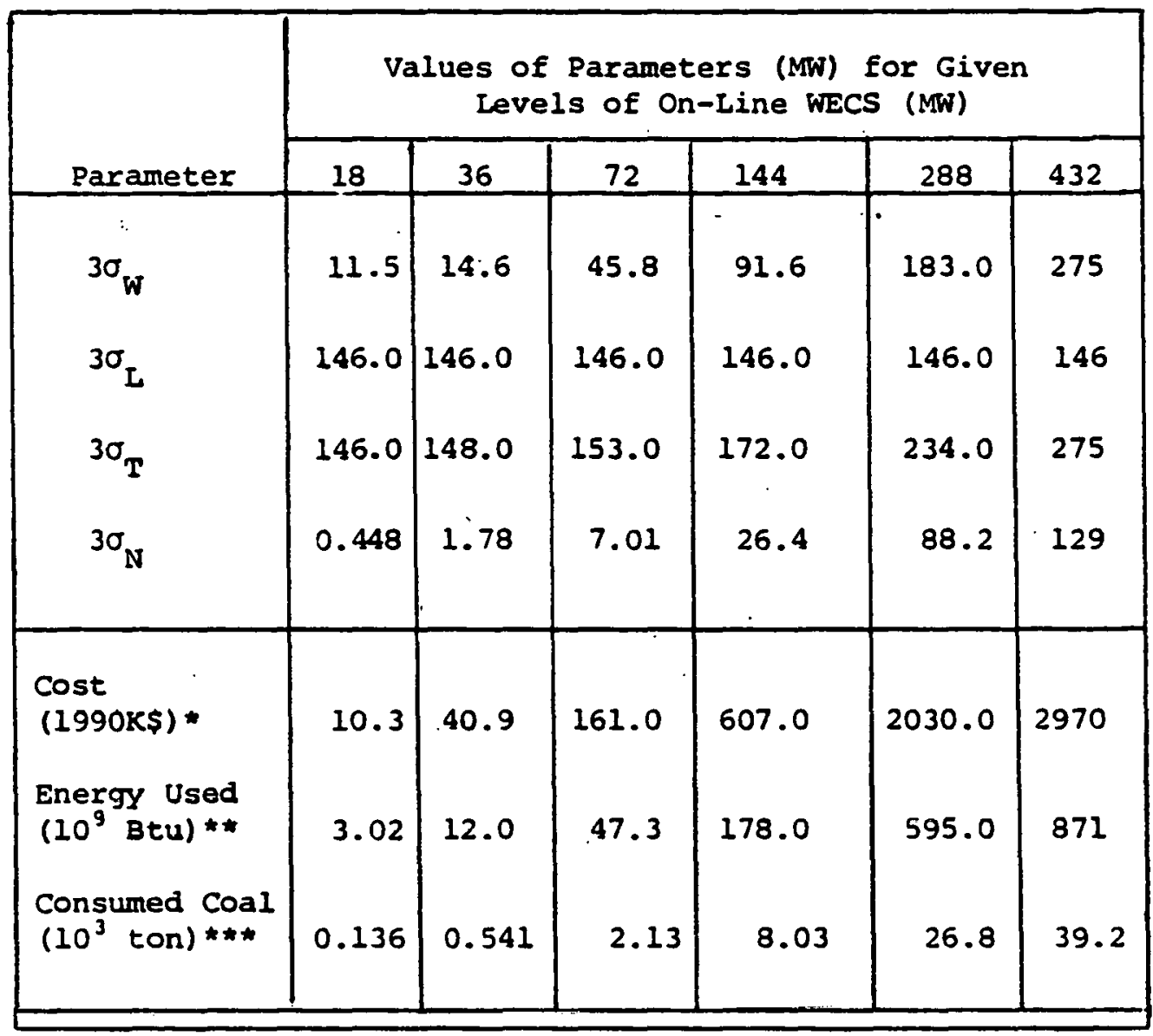

* $23.00 \times 10^{3} \$ / \mathrm{MW} /$ year

* $6.570 \times 10^{9} \mathrm{Btu} / \mathrm{MW} /$ year

$\star \star \star 0.30417 \times 10^{3}$ tón/MW/year 


\subsection{Proposed Expansion Plan and WECS}

\subsubsection{WECS Capacity Credit}

Calculations of WEC Capacity Credit (CC) follow the methodology of section 1.6 with the exception that the graphical method was replaced by linear regression. The Millville $100 \mathrm{KW}$ wind turbine is the representative machine and Indianapolis, the representative site.

\section{Assumptions :}

- The regional utility has the conventional equipment mix described in Table 16, section 2.2.2. Each peaking unit is assumed to have a capacity of $31.73 \mathrm{MW}$.

- The utility without-WECS LOLP is equal to 21.76 . This value represents the reliability standard of the utility.

- The levelized fixed cost of peaking capacity in 1990 is assumed to be $\$ 100 / \mathrm{kW} /$ year.

Capacity credit calculations for the various levels of WECS are displayed in Table.19. Note that at these levels each doubling of on-line WECS capacity doubles the capacity credit. The annual LOLP is very nearly a linear function of the number of peaking units (assuming that the number of base-loaded and intermediate units remains the same).

The annual fixed cost savings which may be attributed to wecs are qiven in Table 20. The savings are calculated based on a peaking capacity levelized fixed cost of $\$ 100 / \mathrm{kW} /$ year. 
Table 19. CAPACITY CREDIT CALCULATIONS FOR VARIOUS ON-LINE LEVELS OF WECS

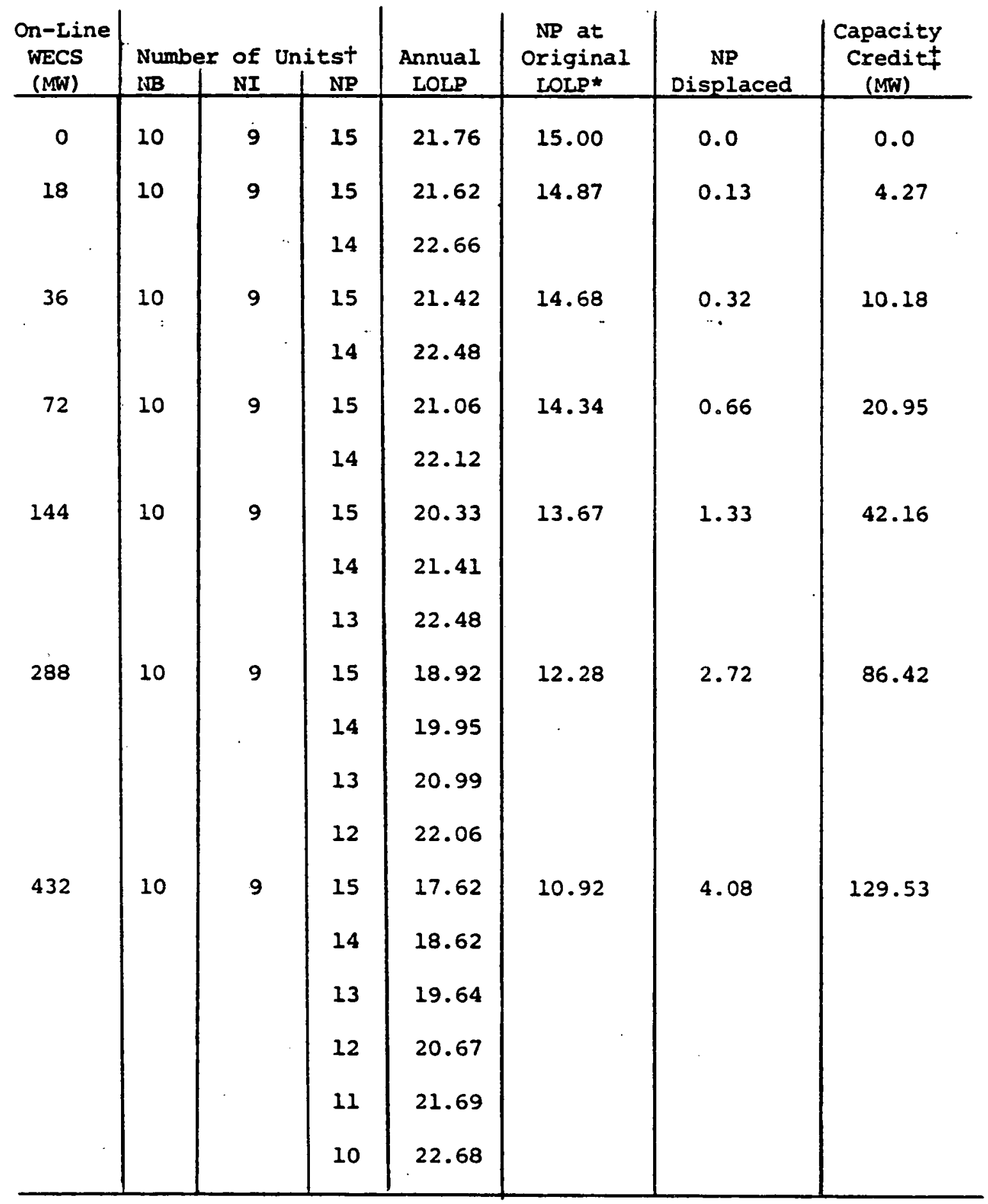

\footnotetext{
$\dagger_{\text {NB }}=$ Number of base-loaded units NI = Number of intermediate units NP $=$ Number of peaking units
}

*Calculated using linear regression.

fEach peaking unit displaced is assumed to have a capacity of $31.73 \mathrm{MW}$. 
Table 20.

FIXED COST SAVINGS F'ROM CREDITED CAPACITY

OF WECS (THOUSANDS OF 1990 DOLLARS)

\begin{tabular}{c|c|c|c}
$\begin{array}{c}\text { TOTAL WECS } \\
\text { Penetration } \\
(8)\end{array}$ & $\begin{array}{c}\text { On-Line } \\
(\mathrm{MW})\end{array}$ & $\begin{array}{c}\text { Capacity } \\
\text { Credit } \\
\text { (MW) }\end{array}$ & $\begin{array}{c}\text { Fixed Cost } \\
\text { Savings } \\
\text { (KS) }\end{array}$ \\
\hline $1 / 4$ & 18 & 4.27 & 427 \\
$1 / 2$ & 36 & 10.18 & 1018 \\
1 & 72 & 20.95 & 2095 \\
2 & 144 & 42.16 & 4216 \\
4 & 288 & 86.42 & 8642 \\
6 & 432 & 129.53 & 12953 \\
\hline
\end{tabular}




\subsection{Reduction in Fuel Consumption}

The reduction of fuel consumption due to WECS was determined using the production costing algorithm PROCOST. Based on the dispatched energy of each unit, its heat rate, and the heat content of the fuel, the amount of fuel consumed at each wECS penetration level was calculated for each unit and for the entire generating system. The results are reproduced in Appendix E. The heat rate of each unit may be found in Table 15, and Table 21 displays the heat content of the fuels. Table 22 summarizes the results in terms of total fuel consumed and fuel savings due to WECS. These results are plotted in Figure 31. Note that the relative change in fuel consumption is very large for oil and rather small for coal, which reflects the difference in fuel prices / approximately $\$ 20 / \mathrm{MBtu}$ for oil versus $\$ 3.50 /$ MBtu for coal (1990 dollars)). Nuclear fuel consumption is unaffected.

The effect of wECS utilitzation on the capacity factors of selected units is documented in Table 23 and Figure 32. Base-loaded units are barely affected and intermediate units, only to an extent comparable to the percent of WECS penetration. Peaking units suffer drastically reduced capacity factors, approaching 608, for coal-fired units at 480 MW (68) WECS penetration and 908 for oil-fired units. Oil-fired units are virtually retired by the higher penetrations of WECS. Nevertheless, it is wise to keep in mind Dewinkel's comments pertaining to the DPC when interpreting these results: ${ }^{1}$

The decrease in oil consumption is based upon the assumptions used in the production cost computer model of the DPC. However, in actual practice on the DPC system, oil savings due to the operation of WECS will probably not be those shown.... Currently, DPC's greatest use of oil is for flame stabilization and start-up of coal-fired units. The use of WECS may require coal-fired units to cycle, resulting in the higher use of oil. 
Table 21.

HEAT CONTENT OF COAL, OIL, AND NUCLEAR FUEL

\begin{tabular}{l|l|l} 
Fuel & Station & Heat Content \\
\hline COAL & Cayuga & $10,400 \mathrm{Btu} / \mathrm{lb}$ \\
& Edwardsport & 10,850 \\
& Gallagher & 11,000 \\
& Gibson & 10,765 \\
& Noblesville & 10,850 \\
& Wabash River & 10,800 \\
& mean value & $\begin{array}{l}10,800 \mathrm{Btu} / 1 \mathrm{~b} \\
(21.6 \mathrm{MBtu} / \mathrm{ton})\end{array}$ \\
\hline \multirow{2}{*}{ OIL } & & $\begin{array}{l}137,000 \mathrm{Btu} / \mathrm{gal} \\
(0.137 \mathrm{MBtu} / \mathrm{gal})\end{array}$ \\
& & $\begin{array}{l}10,500 \mathrm{Btu} / \mathrm{kWh} \\
(252 \mathrm{MBtu} / \mathrm{MW} \cdot \mathrm{day})\end{array}$ \\
& &
\end{tabular}


Table 22.

REGIONAI UTILITY'S FUEL USAGE AS A

FUNCTION OE WECS CAPACITY

\begin{tabular}{|c|c|c|c|c|c|c|}
\hline \multicolumn{2}{|c|}{$\begin{array}{c}\text { Total WECs } \\
\text { Capacity }\end{array}$} & \multicolumn{4}{|c|}{$\begin{array}{l}\text { Production Cost Model } \\
\text { Fuel Usage* }\end{array}$} & \multirow{3}{*}{$\begin{array}{c}\text { WECS Operating } \\
\text { Reserve Requirement } \\
\text { COAL } \\
\text { Consumed } \\
\left(10^{3} \cdot \text { ton }\right) \\
\end{array}$} \\
\hline & & \multicolumn{2}{|c|}{ COAL } & \multicolumn{2}{|c|}{ OIL } & \\
\hline $\begin{array}{c}\text { Installed } \\
\text { (MW) }\end{array}$ & $\begin{array}{c}\text { On-Line } \\
\text { (IW) }\end{array}$ & $\begin{array}{l}\text { Consumed } \\
\left(10^{3} \text { ton }\right) \\
\end{array}$ & $\begin{array}{c}\text { Savings } \\
\left(10^{3} \text { ton }\right) \\
\end{array}$ & $\begin{array}{l}\text { Consumed } \\
\left(10^{3} \text { gal }\right)\end{array}$ & $\begin{array}{l}\text { Savings } \\
\left(10^{3} \text { gal }\right)\end{array}$ & \\
\hline 0 & 0 & 8,351 & 0 & 4,785 & 0 & 0.0 \\
\hline 20 & 18 & 8,336 & 15 & 4,387 & 398 & 0.136 \\
\hline 40 & 36 & 8,321 & 30. & 4,024 & 761 & 0.541 \\
\hline 80 & 72 & 8,291 & 60 & 3,375 & 1,410 & 2.130 \\
\hline 160 & 144 & 8,229 & 122 & 2,294 & 2,491 & 8.030 \\
\hline 320 & 288 & 8,102 & 249 & 1,041 & 3,744 & 26.800 \\
\hline 480 & 432 & 7,973 & 378 & 555 & 4,230 & 39.200 \\
\hline
\end{tabular}

*NUCLEAR fuel consumption $=519,479 \mathrm{MW}$-days for all the given WECS levels. 
FIGURE 31. REGIONAL UTILITY'S COAL AND OIL

CONSIJMPTION VERSLS AECS PENETRATION

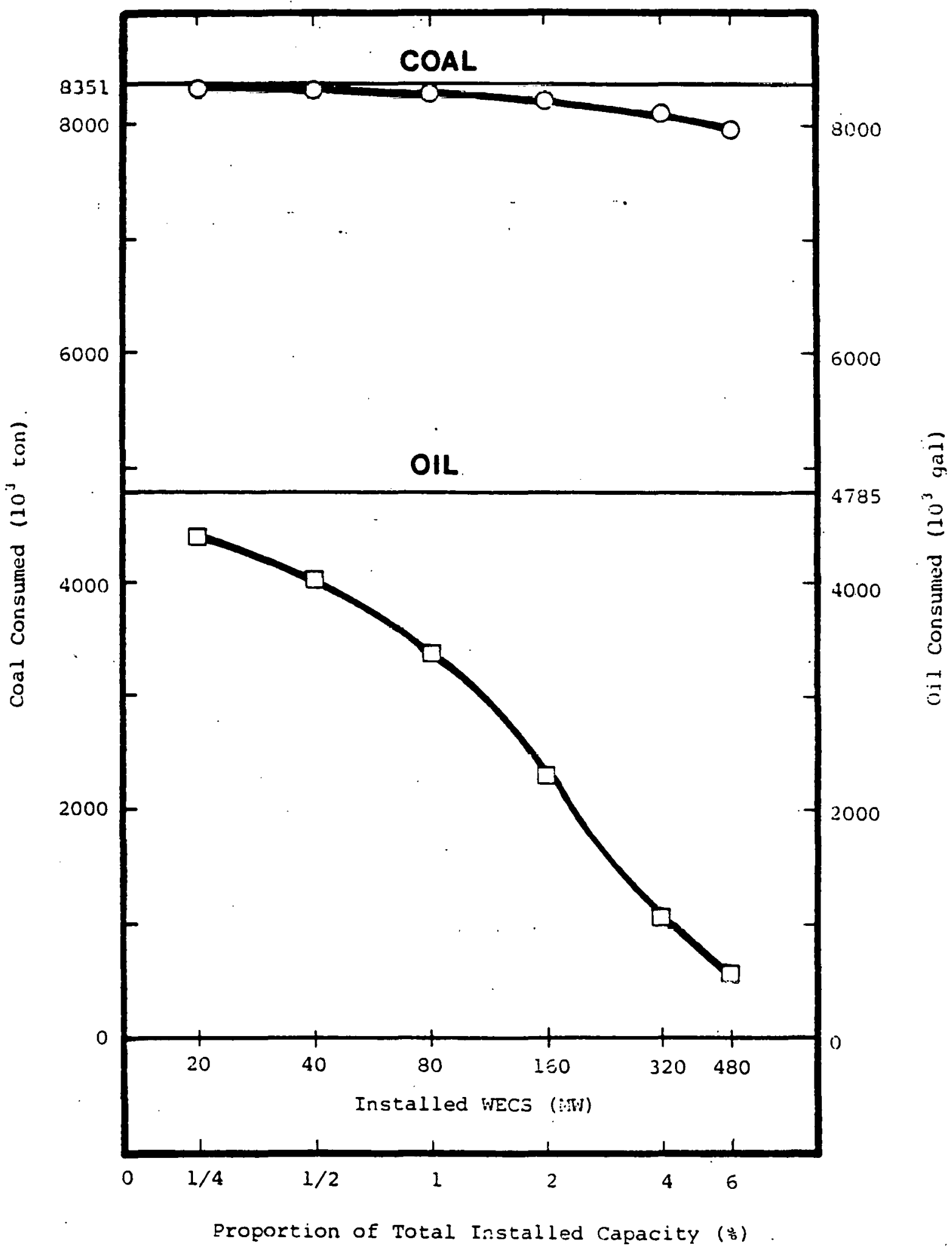


Table 23.

ANNUAL CAPACITY FACTORS OF SELECTED UNITS FOR VARIOUS LEVELS OF WECS PENETRATION

\begin{tabular}{|c|c|c|c|c|c|c|c|c|c|}
\hline \multirow[b]{2}{*}{$\operatorname{Unit}(s) \star$} & \multicolumn{7}{|c|}{$\begin{array}{l}\text { Annual Capacity Factor for Given } \\
\text { Levels of WECS Penetration (MW and } 8 \text { ) }\end{array}$} & \multirow[b]{2}{*}{$\begin{array}{l}\text { Load } \\
\text { Type }\end{array}$} & \multirow[b]{2}{*}{$\begin{array}{l}\text { Fuel } \\
\text { Type }\end{array}$} \\
\hline & $\begin{array}{l}0 \\
08 \\
\end{array}$ & $\begin{array}{l}29 \\
1 / 4\end{array}$ & $\begin{array}{l}40 \\
1 / 2\end{array}$ & $\begin{array}{r}80 \\
1 \\
\end{array}$ & $\begin{array}{c}160 \\
2\end{array}$ & $\begin{array}{c}320 \\
4 \\
\end{array}$ & $\begin{array}{c}480 \\
6 \\
\end{array}$ & & \\
\hline$\overline{1-4}$ & .408 & .408 & .408 & .407 & .406 & .403 & .400 & BASE & COAL \\
\hline 16 & .207 & .206 & .204 & .201 & .200 & .185 & .174 & BASE & COAL \\
\hline$\overline{7-10}$ & .432 & .430 & .429 & .426 & .419 & .404 & .388 & INTER & COAL \\
\hline 15 & .068 & .068 & .068 & .067 & .067 & .065 & .064 & INTER & COAL \\
\hline$\overline{19-21}$ & .151 & .147 & .143 & .135 & .120 & .090 & .064 & PEAK & COAL \\
\hline$\overline{28-29}$ & .038 & .035 & .032 & .026 & .017 & .007 & .004 & PEAK & OIL \\
\hline 30 & .070 & .066 & .064 & .054 & .039 & .020 & .009 & PEAK & OIL \\
\hline 31 & .080 & .074 & .069 & .063 & .044 & .022 & .009 & PEAK & OIL \\
\hline
\end{tabular}

*Overtyped bar indicates average. 
FIGURE 32. CAPACITY FACTORS OF SELECTED GENERATING INITS VERSUS WECS PENETRATION

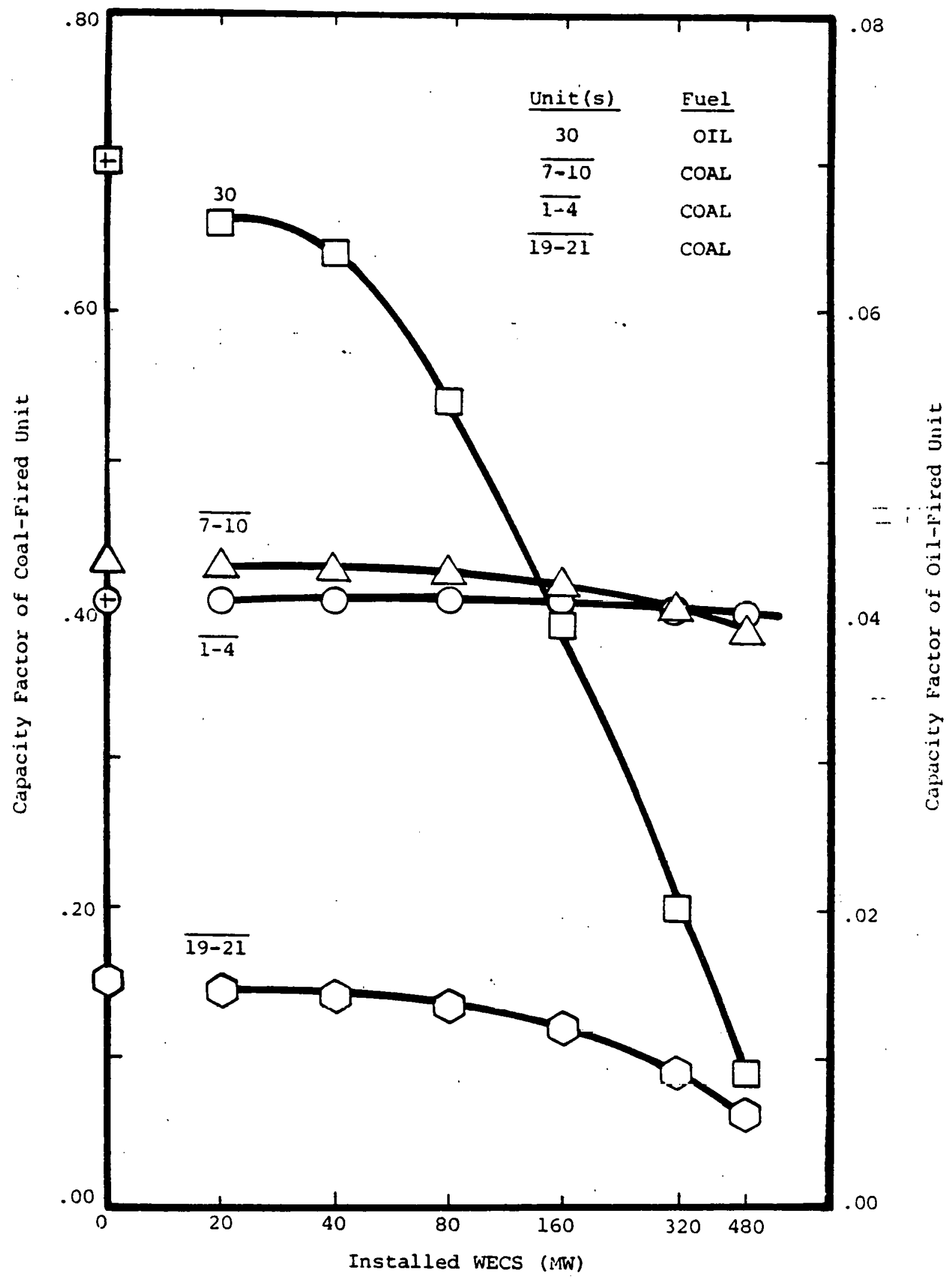


NOTES $(2.3)$

1. DEW, 71. 


\subsection{JBF Economic Analysis}

\subsubsection{Methodology}

Nearly all of the JBF computer programs are involved in the economic analysis. The components of an analysis of WECS life-cycle savings are displayed in Figure 33. An array of Millville 100 $\mathrm{kW}$ wind turbines is assumed to operate in a wind regime similar to that of Indianapolis. The utility load is the average of five years of Public service Indiana (PSI) load data projected to 1990. The 1990 equipment mix of PSI is assumed to apply. 
FIGURE 33. ELEMENTS OF JBF ECONOMIC ANALYSIS

OF WECS LIFE-CYCLE SAVINGS

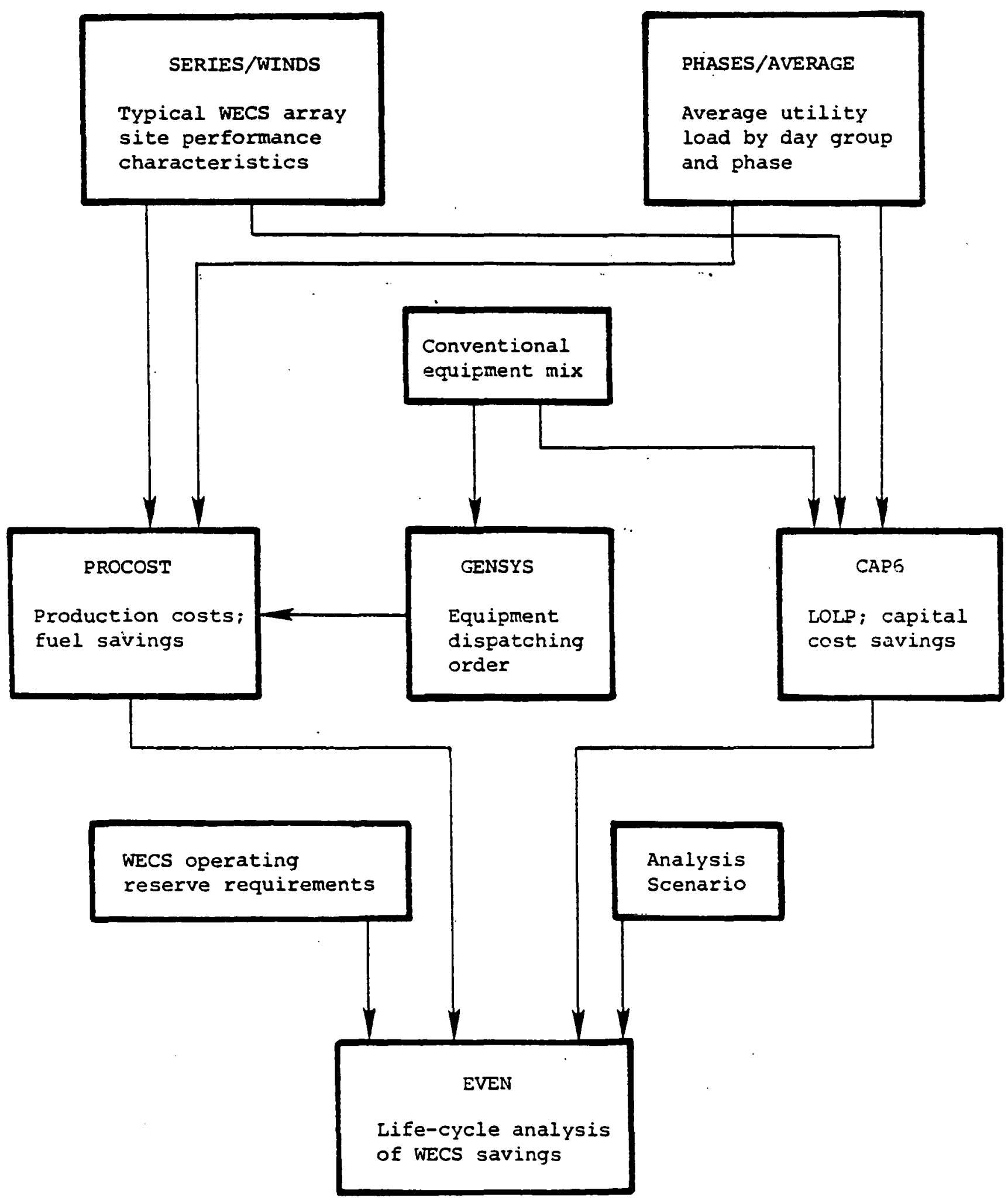




\subsection{JBF Economic Analysis}

\subsubsection{Production Cost Savings}

Savings attributable to WECS equal the difference between the production costs of the representative regional utility without WECS and those of the utility with wECS. Appendix E contains the results of the production cost model simulations for various levels of WECS. Offsetting the production model fuel cost savings is the additional sost of wECS operating reserve (Table 18). Total savings are augmented by the inclusion of the capacity credit value of the WECS (Table 20). Table 24 sumnarizes the available Funds arising from fuel and fixed cost savings for the Millville $100 \mathrm{kw}$, wind turbine. Notice that although the majority of these savings result from a reduction in fuel cost, the fixed cost savings proportion of the total rises from $16 \%$ at 18 MW WECS On-line to 268 at 480 MW WECS On-line. The decreasing proportion of fuel cost savings is due to less expensive fuels being displaced at higher WECS penețrations. 
Table 24.

THE 1990 AVAILABLE FUNDS FOR THE MILLVILLE 100KW

WIND TURBINE. (THOUSANDS OF 1990 DOLLARS)

\begin{tabular}{|c|c|c|c|c|c|c|c|c|c|}
\hline $\begin{array}{l}\text { TOTAL } \\
\text { Installed } \\
\text { (MW) }\end{array}$ & $\begin{array}{l}\text { WECS } \\
\text { On-Line } \\
(\mathrm{MW})\end{array}$ & $\begin{array}{c}\text { Total } \\
\text { Operating } \\
\text { Cost } \\
(\mathrm{KS})\end{array}$ & $\begin{array}{c}\text { Fuel } \\
\text { Cost } \\
\text { Savings } \\
(\mathrm{K} S)\end{array}$ & $\begin{array}{l}\text { WOR } \\
\text { Cost' } \\
\text { (KS) }\end{array}$ & $\begin{array}{c}\text { Capacity } \\
\text { Credit } \\
\text { Valuet. } \\
\text { (KS) }\end{array}$ & Euel & $\begin{array}{r}\text { ilable } \\
(\mathrm{KS}) \\
\text { Fixed }\end{array}$ & Total & $\begin{array}{l}\text { Total Funds } \\
\text { per Instal- } \\
\text { led WECS } \\
(\mathrm{K} \$ / \mathrm{MW})\end{array}$ \\
\hline 0 & 0 & 777,244 & 0 & 0 & 0 & 0 & 0 & 0 & 0.0 \\
\hline 20 & 18 & 774,993 & 2,251 & 10 & 427 & 2,241 & 427 & 2,668 & 133.4 \\
\hline 40 & 36 & 772,833 & 4,411 & 41 & 1,018 & 4,370 & 1,018 & 5,388 & 134.7 \\
\hline 80 & 72 & 768,716 & 8,528 & 161 & 2,095 & 8,367 & 2,095 & 10,462 & 130.8 \\
\hline 160 & 144 & 761,073 & 16,171 & 607 & 4,216 & 15,564 & 4,216 & 19,780 & 123.6 \\
\hline 320 & 288 & 748,252 & 28,992 & 2,030 & 8,642 & 26,962 & 8,642 & 35,604 & 111.3 \\
\hline 480 & 432 & 737,589 & 39,655 & 2,970 & 12,953 & 36,685 & 12,953 & 49,638 & 103.4 \\
\hline
\end{tabular}

twoR cost represents additional fuel costs for operating reserve.

Capacity credit value is a fixed cost savings for credited capacity. 


\subsection{JBF Economic Analysis}

\subsubsection{Life-Cycle Analysis and Break-Even Cost of WECS}

Once the annual fuel cost and capital (fixed) cost savings have been determined, a life-cycle analysis may be carried out for the WECS. The cost of providing WECS operating reserve should be included in the analysis, although for this example it has been neglected. The assumptions of the analysis are presented in the analysis scenario of Table 25 . Under the category "General Economic Conditions", the near-term inflation rate (1980-1989) is set at 88 and the long-term rate (1990 onward) at 68. Long-run average annual rate of growth of total savings is related to the inflation rate and real fuel cost escalation rate by the formula

$$
\begin{aligned}
& \left(1+\begin{array}{c}
\text { rate of growth } \\
\text { of total savings }
\end{array}\right)=\left(1+\begin{array}{c}
\text { inflation } \\
\text { rate }
\end{array}\right)\left(1+\begin{array}{l}
\text { real fuel cost } \\
\text { escalation rate }
\end{array}\right) \\
& 1.0812=(1.06)(1.02) \\
& \begin{array}{l}
\text { rate of growth } \cong 0.081 \\
\text { of total savings }
\end{array}
\end{aligned}
$$

The 108 cost of capital (under "Utility Description") corresponds to a 68 long-run inflation rate. A 3.88 cost of capital in an inflation-free environment is assumed. An 88 inflation rate would yield a 12.18 weighted cost of capital and 98 inflation gives 138 weighted cost of capital. The results of the life-cycle analysis for an array of Millville $100 \mathrm{KW}$ wind turbines are presented in Tables 26 and 27. Marginal savings are determined by differentiating the spline-fit curve of 1990 present values. Calculations were conducted for WECS in the fuel plus capital cost savings mode and the more conservative fuel savings only mode. Note that the 
General Economic Conditions

Long-run average annual rate of growth of total savings

Long-run average annual rate of growth of operating and maintenance costs (conventional equipment)

$$
0.06
$$

Average annual rate of growth of interfacing equipment and land cost prior to the date at which they are actually incurred (set equal to near-term inflation)

Long-run average annual rate of growth of "other taxes" (Primarily property taxes)

Long-run average annual rate of appreciation for land values after the utility develops it .. ...

Inflation rate $(1980-1989)$. (1990 onward)

0.00

0.08

0.06

\section{Utility Description}

Cost of capital based on the long-run debt-equity structure of the utility

Effective income tax rate. The marginal rate after any adjustments peculiar to the utility

\section{WECS Description}

Availability

0.9

Ratio of purchased land cost to total land cost including easements needed for a wECS

The rated capacity of a wecs unit in kilowatts

100

WECS operating life in years

Ratio of annual insurance premiums to acquisition cost

Ratio of first year operating and maintenance cost to the capitalized cost of owned WECS assets

First year's property taxes expressed as a proportion of the capitalized cost of owned WECS assets

\section{Scenario Description}

The first year of wECS operation

The year in which land cost estimates are compiled

The year in which interfacing cost estimates are made

The year in which land is acquired

The year in which WECS are purchased

Land cost per weCS installation 
Table 26.

THE 1990 PRESENT VALUE OF THE TOTAL 30 yeAR SAVINGS

talled

WECS

(MW)

0

20

40

80

$\stackrel{\omega}{\omega}$

\section{The 1990 present Value \\ of the Total 30 Year Savings (M\$)

In Fuel Costs In Capital Costs Total

$$
0.0
$$

48.0

93.6

179. 3

333.5

577.7

786.0
0.0

9.1

21.8

44.9

90.3

185.2

277.5
0.0

57.2

115.4

224.2

423.8

762.8

$1,063.5$
Marginal Savings Per 100KW

WECS Installation (KS)

Fuel \& Capital Fuel Only

284

243

290

235

287

222

262

207

236

177

195

136

185 
Table 27.

THE 1989 INSTALIATION AND UNIT VALUES

OF THE WECS FOR THE 30-YEAR ANALYSIS

\begin{tabular}{c}
$\begin{array}{c}\text { Installed } \\
\text { WECS } \\
\text { (MW) }\end{array}$ \\
\hline 0 \\
20 \\
40 \\
80 \\
160 \\
320
\end{tabular}

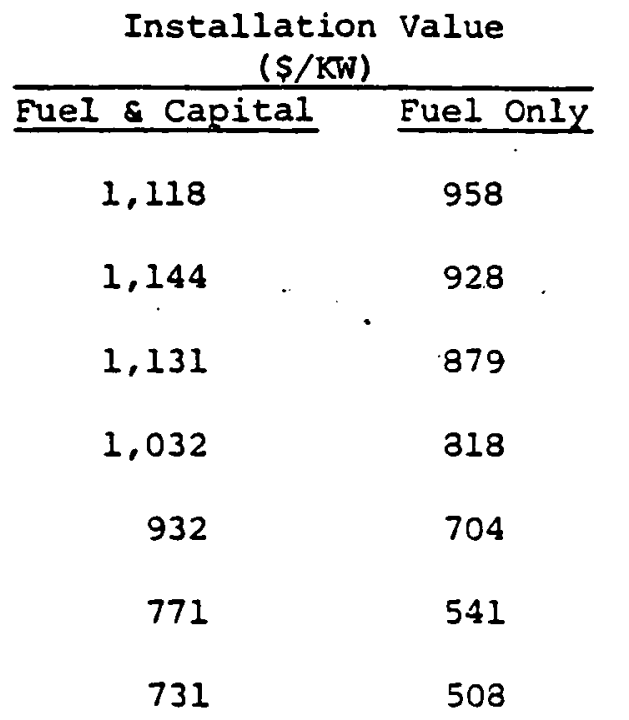

\begin{tabular}{|c|c|c|}
\hline Fuel & $\&$ Capital & Fuel Only \\
\hline & 755 & 596 \\
\hline & $78 \cdot \mathbf{1}$ & 565 \\
\hline & 768 & 516 \\
\hline & 669 & 455 \\
\hline & 569 & 341 \\
\hline & 408 & 178 \\
\hline & 368 & 145 \\
\hline
\end{tabular}


marginal present value typically decreases with wECS penetration, i.e., each MW of WECS added to the utility is of less value than the previous. This is due primarily to the fact that each additional WeCs unit displaces equipment with lower incremental (primarily fuel) costs.

Table 27 displays the installation and unit value of the WECS in the year in which the WECS are purchased, namely 1989. Both modes of analysis are represented. By subtracting land and interface costs from the installation value, the WECS unit value was obtained. The unit value represents the break-even cost of the wind turbine itself in 1989 . This cost must be compared to manufacturers' list prices to determine if WECS are economically competitive. In order to get an idea of how the 1989 unit values compare to 1980 prices, one may bring them back to 1980 by dividing them by an inflation factor of $(1.08)^{9}=2.00$. Thus, for example, the $\$ 781 / \mathrm{kW}$ unit value of WECS in the fuel plus capital mode at 20 MW penetration is equivalent to $\$ 390.5 / \mathrm{kW}$ in 1980 dollars.

Figure 34 shows the break-even costs of the Millville 100kW wind turbine, which has a rated power density of $244 \mathrm{w} / \mathrm{m}^{2}$. For comparison, the break-even costs of the NASA/DOE MOD-O wind turbine are shown in Figure 35. This machine has a rated power density of $93 \mathrm{w} / \mathrm{m}^{2}$. Its break-even cost is nearly twice that of the Millville machine, thus demonstrating that the machine with the lower rated power density is much more suitable for Indiana wind regimes, despite the extra cost of larger diameter blades. The two graphs show breakeven cost per $\mathrm{kW}$ of WECS as a function of annual fuel price increase (equivalent to the annual rate of growth of fuel savings) and annual WECS O\&M cost. For the analysis scenario, the fuel savings growth rate is nominally 8.17 and the WECS D\&M cost is set to $3 \%$ of the capital cost. WECS installed 
FIGURE 34. BREAK-EVEN CAPITAL COST OF MILLVILLE 10OKW

WIND IACHINE WITH RATED POWER DENSITY OE $244 \mathrm{~W} / \mathrm{m}^{2}$

(1989 DOLLARS)

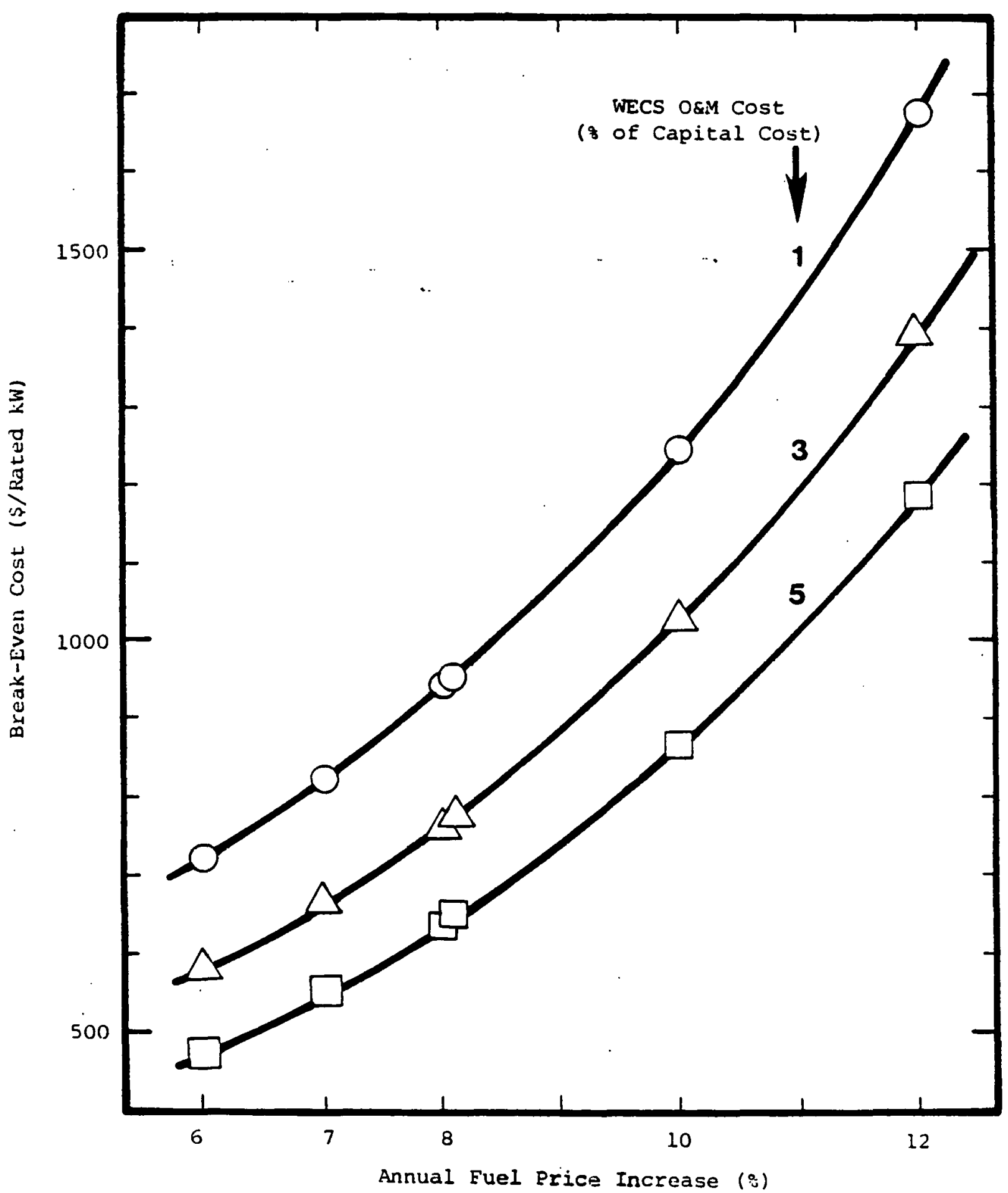


FIGURE 35. BREAK-EVEN CAPITAL COST OF NASA/COE MOD-O LOOKH WIND LLACHINE WITH RATED POWER DENSITY OF $93 \mathrm{~m} / \mathrm{m}^{2}$ ( 1989 DOLLARS)

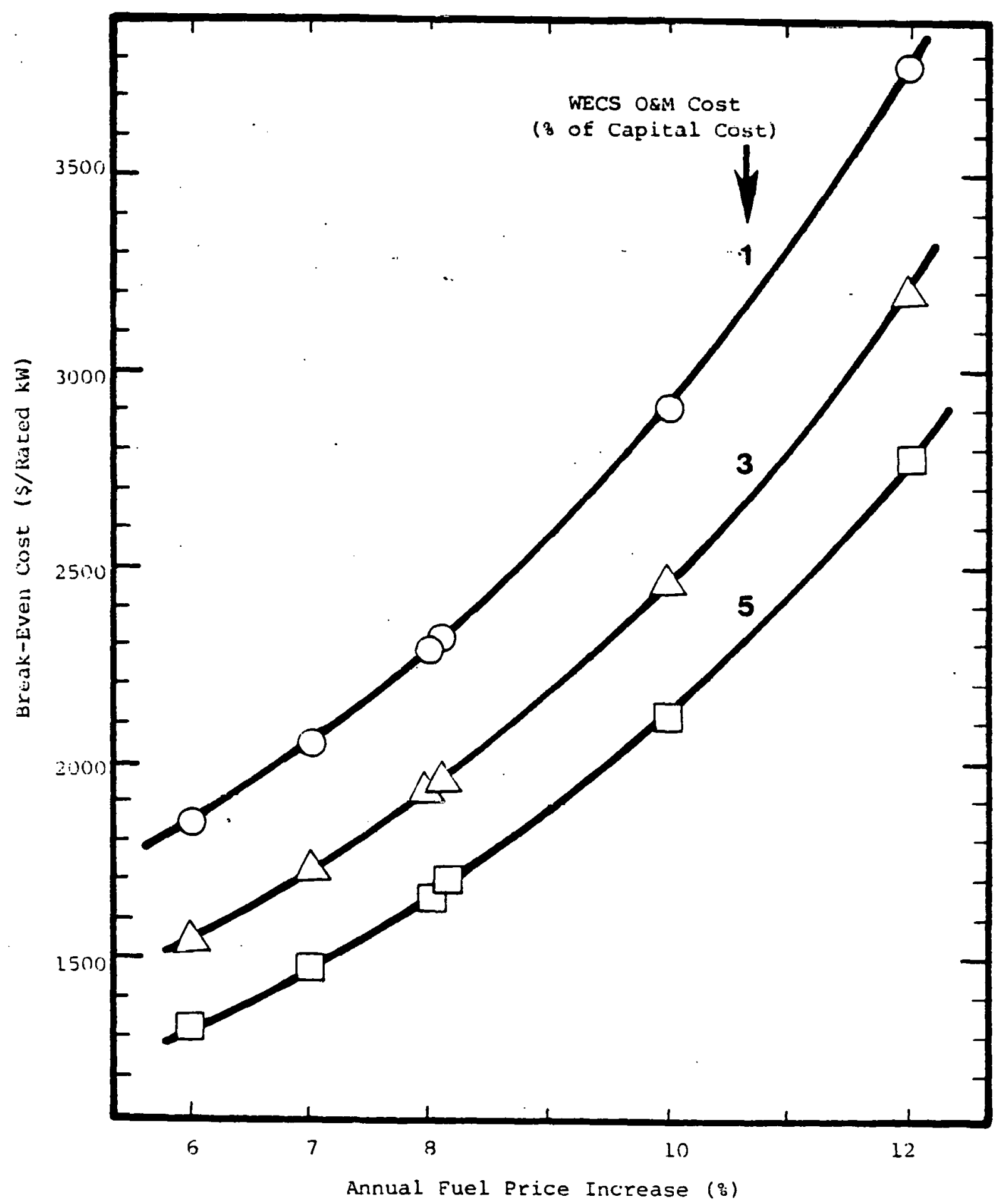


capacity is equal to $20 \mathrm{MW}$ in 1990 . The general inflation rate is $6 \%$. Production model fuel savings, wOR fuel costs, and fixed cost savings due to credited capacity are all entered into the calculations. Values are expressed in 1989 dollars. 


\subsection{Busbar Analysis of wECS}

\subsubsection{Methodology}

Busbar cost is a useful means of comparing the revenue requirements per unit of output of generating alternatives in a simplified manner. It is defined as the levelized revenue requirements of a generating option divided by the annual levelized kilowatt hour output (levelized cver the life of the machine) and is expressed in milis per kilowatt nour (mills $/ \mathrm{kWh})$.

A sample calculation of levelized annual busbar cost for a hypothetical wird turbine is displayed below.

\section{Data Assumptions: (end-of-year 1980 dollars)}

Rated power

Installed cost $(\$ 60,000)$ *

Useful life

Capacity factor
$100 \mathrm{~kW}$

$\$ 600 / \mathrm{kW}$

30 years

\begin{tabular}{|c|c|c|c|}
\hline years & $\begin{array}{l}\text { wind power } \\
\text { capacity }+\end{array}$ & $\begin{array}{l}\text { avail- } \\
\text { ability }+\end{array}$ & $\begin{array}{l}\text { Capacity } \\
\text { Eactor }\end{array}$ \\
\hline $1-10$ & .25 & .9 & .225 \\
\hline $11-20$ & .25 & .85 & .213 \\
\hline $21-30$ & .25 & .8 & .200 \\
\hline
\end{tabular}

* $\$ 50,000$ for wind turbine $+\$ 10,000$ siting costs.

+ Annual capacity factor based on machine's performance at a particular site.

I Availability is the fraction of a year that the machine is actually operating and producing power. 
Fixed O\&M costs

$\$ 10 / \mathrm{kw} / \mathrm{yr}$

Variable O\&M costs

$2 \mathrm{mills} / \mathrm{kWh}$

Inflation

88/year

Cost of capital (discount rate)

128

Real escalation rate

08

Date of commercial operation

end-of-year 1980

- Levelized capacity factor

$$
\begin{aligned}
& =\left[.225 \times \mathrm{PWF}_{10}+.213\left(\mathrm{PWF}_{20}-\mathrm{PWF}_{10}\right)\right. \\
& \left.+.200 \times\left(\mathrm{PWF}_{30}-\mathrm{PWF}_{20}\right)\right] \times \mathrm{CRF}_{30}
\end{aligned}
$$

where

$$
\begin{aligned}
& \mathrm{PWF}_{10} \begin{array}{r}
\text { Uniform series present worth factor for } \\
128 \text { and } 10 \text { years. }
\end{array} \\
& \mathrm{CRF}_{30}=\text { Capital recovery factor for } 128 \text { and } 30 \text { years. } \\
& =[.225 \times 5.650+.213 \times(7.469-5.650) \\
& +.200 \times(8.055-7.469)] \times .1241 \\
& =.220
\end{aligned}
$$

- Levelized annual fixed charge rate $=.21$ (assumed present-day typical figure for 30 year useful life).

- Levelizing factor

$$
L_{f}=\operatorname{CRF}\left[\frac{k\left(1-k^{n}\right)}{1-k}\right]
$$

where

$$
\begin{aligned}
& C R F=\text { capital recovery factor } \\
& r \quad=\text { discount rate } \\
& n \quad=\text { book life }
\end{aligned}
$$




$$
\begin{aligned}
\mathrm{k}= & \frac{(1+e)}{(1+r)} \\
\mathrm{e}= & \text { apparent escalation rate such that } \\
& (1+e)=(1+\text { real esc. rate })(1+\text { inflation rate }) \\
\mathrm{e}= & .08, \mathrm{k}=\frac{1+.08}{1+.12}=.964, \mathrm{CRF}(128, .30 \text { years })=.1241 \\
\mathrm{~L}_{f}= & .1241 \times[17.931]=2.225
\end{aligned}
$$

- Levelized annual capital cost

$$
\begin{gathered}
\frac{\text { capital cost }\left[\frac{S}{\mathrm{~kW}}\right] \text { levelized annual fixed charge rate }\left[\frac{1}{\mathrm{yr}}\right] \times 1000\left[\frac{\mathrm{mills}}{\mathrm{s}}\right]}{8760\left[\frac{\mathrm{hrs}}{\mathrm{yr}}\right] \times \text { levelized capacity factor }[-1} \\
=\frac{600 \times .21 \times 1000}{8760 \times .220}=65.4 \mathrm{mills} / \mathrm{kWh}
\end{gathered}
$$

- Levelized annual fuel cost

$$
=0 \mathrm{mills} / \mathrm{kWh}
$$

- Levelized annual O\&M cost

$$
\begin{aligned}
& {\left[\frac{\text { fixed O\&M }}{\left.8760\left[\frac{\mathrm{hrs}}{\mathrm{yr}}\right] \times \frac{\mathrm{s}}{\mathrm{kW} \cdot \mathrm{yr}}\right] \times 1000\left[\frac{\mathrm{mills}}{\mathrm{s}}\right]}\right.} \\
& \left.+\operatorname{variable~O\& M}\left[\frac{\mathrm{mills}}{\mathrm{kWh}}\right]\right] \times \begin{array}{l}
\text { levelizing } \\
\text { factor }
\end{array}[-] \\
& =\left[\frac{10 \times 1000}{8760 \times .220}+2\right] \times 2.225=16.0 \mathrm{mills} / \mathrm{kWh}
\end{aligned}
$$

- Levelized annual busbar cost

= levelized capital cost

+ levelized fuel cost

+ levelized O\&M cost

$=65.4+0.0+16.0=81.4 \mathrm{mills} / \mathrm{kWh}$ 
Graphical methods may be used to obtain a quick estimate of the levelized annual busbar cost of a WECS. The above methodology applies, with a few minor changes. Fixed costs and variable costs are calculated separately. Use Figure 36 to find the levelized annual capital cost in mills/kWh. Begin by combining the levelized capital cost (capital cost [s/kW] times levelized annual fixed charge rate $[1 / Y[$ ]) and levelized fixed $O \& M$ cost to obtain a value in $\$ / k W \cdot y r$. Locate on the graph the line corresponding to this value. For a given levelized capacity factor, calculate the reciprocal ( $1 / \mathrm{Lev}, \mathrm{CF}$ ) and trace vertically from this value to the combined fixed cost line. Now project a line horizontally to the right until it intercepts with the vertical axis. The value of this intercept is the levelized annual fixed cost (capital plus fixed $O \& M$ ) in mills/kWh. (For the example shown on the graph, a wind turbine with a levelized capacity factor of 0.25 and a combined fixed cost of $\$ 300 / \mathrm{kW} \cdot \mathrm{year}$ yields a levelized annual fixed cost of $137 \mathrm{mills} / \mathrm{kWh}$ ). To this value add the levelized annual variable cost (variable o \& M [mills/kWh] times a levelizing factor) in order to obtain the levelized annual busbar cost. The details of the calculations are summarized below.

- Levelized annual fixed cost

$$
\begin{aligned}
& =\frac{\left(\begin{array}{c}
\text { capital } \\
\text { cost }
\end{array}\left[\frac{\mathrm{s}}{\mathrm{kW}}\right] \times \begin{array}{c}
\text { levelized } \\
\text { annual fixed } \\
\text { charge rate }
\end{array}\left[\frac{1}{\mathrm{yr}}\right]+\begin{array}{c}
\text { fixed } \\
\text { O\&M }
\end{array}\left[\frac{\mathrm{s}}{\mathrm{kW} \cdot \mathrm{yr}}\right] \times \begin{array}{c}
\text { levelizing } \\
\text { factor }
\end{array}[-]\right) \times 1000\left[\frac{\mathrm{mills}}{\mathrm{S}}\right]}{8760\left[\frac{\mathrm{hrs}}{\mathrm{Yr}}\right] \times \text { levelized capacity factor }[-]} \\
& =\frac{(600 \times .21+10 \times 2.225) \times 1000}{8760 \times .220}=76.9
\end{aligned}
$$



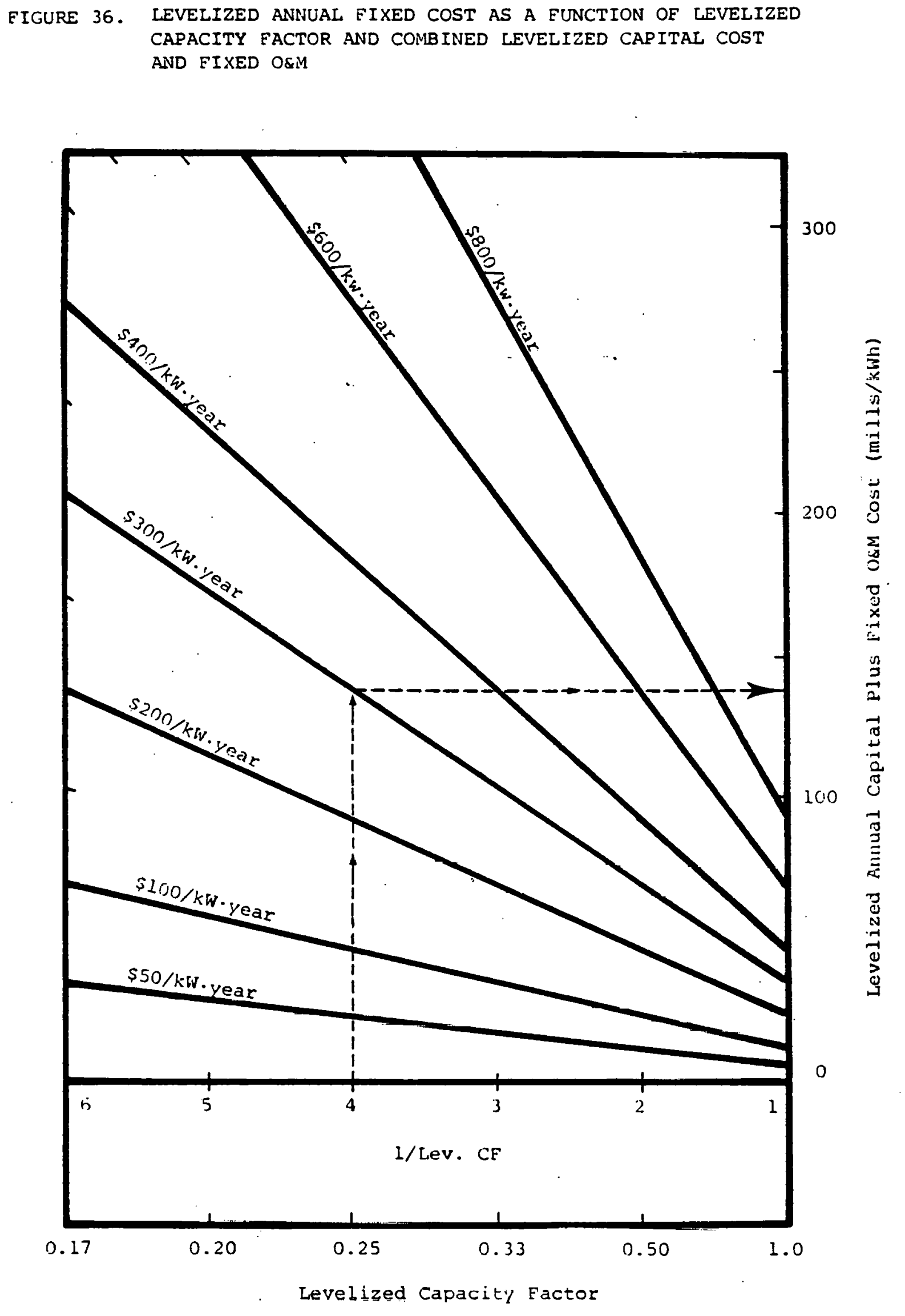
- Levelized annual variable cost

$=\left(\right.$ fuel cost $\left[\frac{\mathrm{mill} s \mathrm{~s}}{\mathrm{kWh}}\right]+$ variable $\left.\mathrm{O \& M}\left[\frac{\mathrm{mills}}{\mathrm{kWh}}\right]\right) \times$ levelizing factor $[-]$

$=(0+2) \times 2.225=4.45$

- Levelized annual busbar cost

$=$ levelized fixed cost + levelized variable cost

$=76.9+4.45=81.4 \mathrm{mills} / \mathrm{kWh}$ 


\subsection{Busbar Analysis of WECS}

\subsubsection{Busbar Analysis of a Selected Wind Turbine}

The Millville $100 \mathrm{~kW}$ wind turbine was selected as a representative wECS for the busbar analysis. Its characteristics are listed in Table 9. Wind data for each of the NCC primary stations used in this study and for Terre Haute was organized into five-year series covering the period 1973-77. The data files contain hourly wind speeds exclusively, Using computer programs SERIES and WINDS, annual average capacity factors were calculated for the Millville wind turbine. The derivation of capacity factors is based on a two-parameter linear regression analysis of the wind data at each site.

The busbar analysis described above was applied to the Millville wind turbine. The same data assumptions were made as for the sample calculation in that report. The results of the analysis for each of the sites are presented in Table 28. Busbar costs range grom a low of. $70.6 \mathrm{mills} / \mathrm{KWH}$ at Fort Wayne to a high of $131.8 \mathrm{mills} / \mathrm{KWH}$ at Evansville. This factor of two difference in cost corresponds to a reciprocal factor of two difference in average power output at the two sites $(29.1 \mathrm{kw}$, Fort Wayne versus $15.1 \mathrm{KW}$, Evansville). In the sample calculation, an assumed wind power capacity of 0.25 yielded a busbar cost of $81.4 \mathrm{mills} / \mathrm{KWH}$. 
Table 28. BUSBAR COSTS FOR A WIND TURBINE WITH

MILLVILLE 100KW PERFORMANCE CHARACTERISTICS

\begin{tabular}{|c|c|c|c|c|c|c|c|c|c|c|c|}
\hline \multirow[t]{2}{*}{ Site } & \multirow{2}{*}{$\begin{array}{l}\text { Site } \\
\text { Code }\end{array}$} & \multirow[b]{2}{*}{ Years } & \multicolumn{2}{|c|}{ Lin.Reg.Param. * } & \multirow{2}{*}{$\begin{array}{c}\text { Annual } \\
\text { Average } \\
\text { Power (KW) }\end{array}$} & \multirow{2}{*}{$\begin{array}{l}\text { Annual } \\
\text { Average } \\
\text { CF }\end{array}$} & \multirow{2}{*}{$\begin{array}{l}\text { Levelized } \\
\text { CF }\end{array}$} & \multicolumn{3}{|c|}{$\begin{array}{l}\text { Levelized Annual } \\
\text { Costs (Mills/KWH) }\end{array}$} & \multirow{2}{*}{$\begin{array}{l}\text { Busbar Cost } \\
\text { (Mills/KWH) }\end{array}$} \\
\hline & & & ALR & BLR & & & & Capital & Fuel & $O \& M$ & \\
\hline Indianapolis & IP & $73-77$ & -.42029 & 1.18054 & 21.7 & .217 & .191 & 75.3 & 0.0 & 17.8 & 93.1 \\
\hline Terre Haute & $\mathrm{TH}$ & $73-77$ & -.33452 & 1.03471 & 17.4 & .174 & .153 & 94.0 & 0.0 & 21.1 & 115.1 \\
\hline Fort Wayne & FW & $73-77$ & -.40546 & 1.18915 & 29.1 & .291 & .256 & 56.2 & 0.0 & 14.4 & 70.6 \\
\hline South Bend & SB & $73-77$ & -.38876 & 1.15287 & 26.3 & .263 & .231 & 62.3 & 0.0 & 15.5 & 77.8 \\
\hline Evansville & EV & $73-77$ & -.26114 & 0.91070 & 15.1 & .151 & .133 & 108.2 & 0.0 & 23.6 & 131.8 \\
\hline Louisville & LV & $73-77$ & -.35752 & 1.08241 & 18.5 & .185 & .163 & 82.3 & 0.0 & 20.0 & 102.3 \\
\hline
\end{tabular}

* Linear Regression Parameters, such that

$C F=A L R+B L R(V B A R / V R)$

where

CF is the capacity factor (power out/rated power)

VBAR is the average wind speed at the site

VR is the rated wind speed of the wind turbine 
3. Integration of WECS into a Regional Utility's Generating System

3.1 Correlation of Wind Availability and the Utility's Load

A cross-correlation of hourly wind power density and utility load was carried out for the three years for which the Indianapolis hourly data and the PSI load data overlap, 1975-77. The correlation coefficients are presented in Table 29. Values vary from .2287 to .2604 . This moderate positive correlation of wind àvailability with the utility load is illustrated by a comparison of the plots of Appendices A and $B$. 
Table 29. Correlation Coefficients for Cross-Correlation of Hourly Wind Power Density at Indianapolis and Public Service Indiana's Load, 1975-1977.

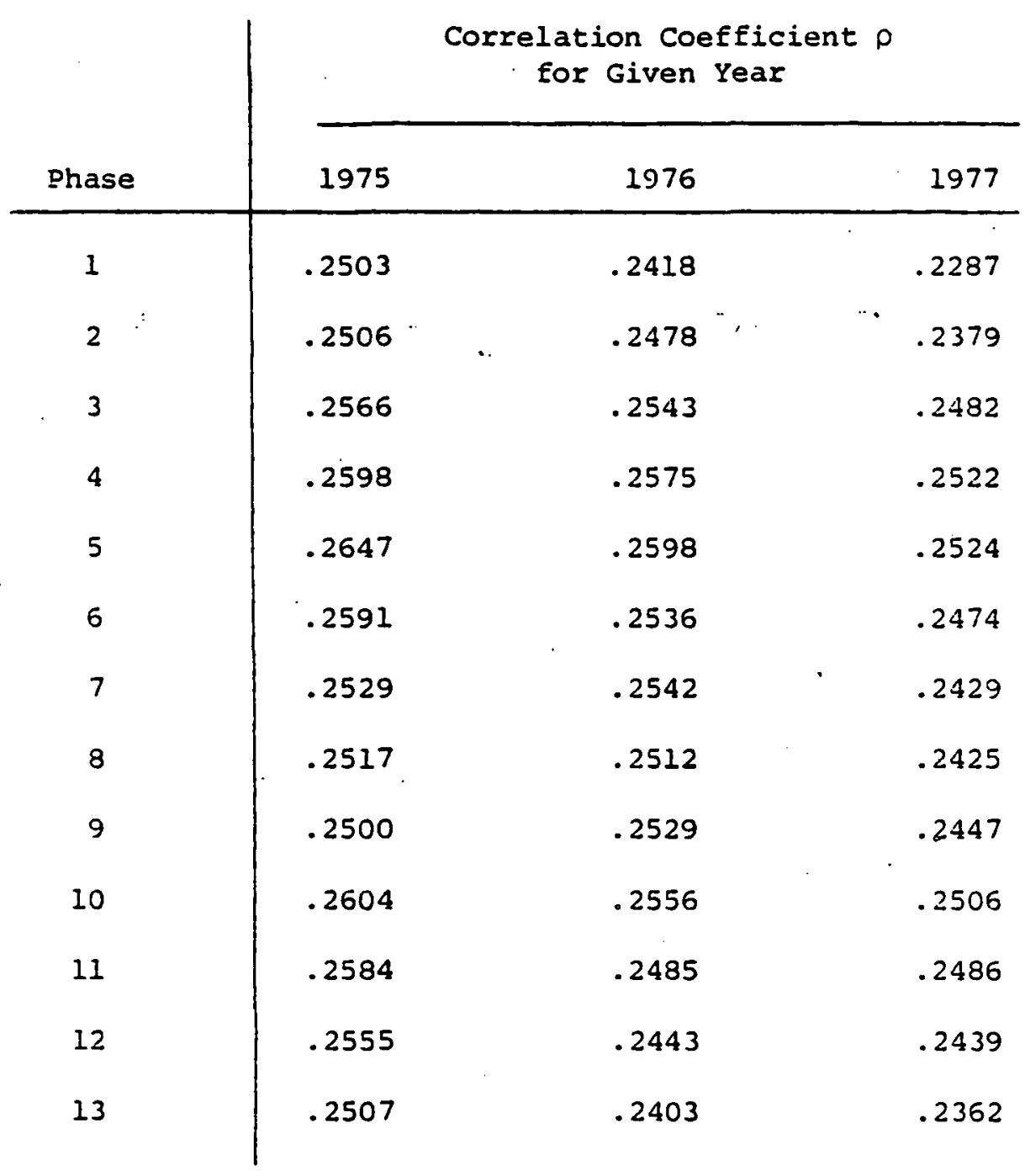


3.2 Economic Evaluation of Combined WECS and Load Control Systems

Since Public Service Indiana presently has no load control systems and does not anticipate installing any in the foreseeable future (not within the next decade, in any case), the economics of combined weCs and load control was not addressed by this study. Dewinkel's study does present a methodology for evaluating çombined WECS, load control, and storage water heating systems, and the reader is referred to that document for further information. 1 
NOTES $(3.2)$

1. DEW, Section VI, 89-113. 


\subsection{Implications of Factoring WECS into the Utility's Proposed}

Expansion Plans

At the low penetration levels considered $(0-6 \%$ of installed conventional capacity), WECS do not have a significant impact on the regional utility's base-load and intermediate capacity. The peaking capacity is dramatically affected, however, in particular the high incremental cost oil-fired units. (See Figure 32) At penetration levels approaching $6 \%$, WECS can reslace the majority of the peaking capacity without incurring too severe WECS operating reserve costs. The combination of weCS plus load control could conceivably offer a reliability equivalent to that of the displaced peaking capacity, thereby eliminating the need for additional operating reserve.

This study has focused on large wind machines of the $50-200 \mathrm{~kW}$ capacity range, presumably owned and operated by the regional utility. Smaller units, owned by a farmer, small business, or homeowner, could also be interconnected with the utility's grid. Questions of interfacing, power conditioning, and an equitable rate structure need then to be addressed by the utility. 
THIS PAGE

WAS INTENTIONALLY

LEFT BLANK 


\section{Summary and Conclusions}

Average annual measured wind speeds in Indiana extrapolated to $30 \mathrm{~m}$ vary from approximately 4.5 to $6.5 \mathrm{~m} / \mathrm{s}$. Stronger winds are observed in the northern part of the state than in the southern, with the central region exhibiting intermediate values.

The annual array capacity factors of the three selected wind turbines operating in an Indianapolis wind regime at height $30 \mathrm{~m}$ varied from 0.243 for the machine with rated power density $\left({ }{ }_{r d}\right) 244 \mathrm{w} / \mathrm{m}^{2}$ to 0.462 for the machine with $P_{r d}=93 \mathrm{w} / \mathrm{m}^{2}--a$ difference in power output of nearly a factor of 2 . These results strongly suggest that wind turbines with low rated power densities are best suited for Indiana's wind regimes.

The economic analyses of WECS break-even costs show that, given the assumptions of the analysis, a wind turbine with $P_{r d}=244 \mathrm{w} / \mathrm{m}^{2}$ would be economically competitive with conventional generating sources were the capital cost not to exceed about $\$ 750$ per rated $k W$ (1989 dollars). This figure for a machine with $P_{r d}=93 \mathrm{w} / \mathrm{m}^{2}$ is nearly $\$ 2000 / \mathrm{kW}$. Brought back to 1.980 dollars by an inflation factor of $(1.08)^{9}=2.00$, these values reckon to $\$ 375 / \mathrm{kW}$ and $\$ 1000 / \mathrm{kW}$, respectively. The former value is clearly unattainable, given present market conditions, ${ }^{1}$ but it may be approached by 1989 should mass production and suitable incentives be applied to WECS in the coming decade. The $\$ 1000 / \mathrm{kW}$ figure is competitive at today's prices and becomes even more appealing as greater knowledge and experience with WECS reduce the initial capital costs in the coming years. 
NOTES (4.)

1. DEW, 113: "Present costs per $\mathrm{kW}$ of capacity range from about. $\$ 500$ to $\$ 1,500 . "$ (January 1979) 


\section{Recommendations}

The recommendations below are directed to Public Service Indiana in particular and to utilities in general:

- Consider participating in the DOE's demonstration and test programs of both small and large WECS. Participation will provide first-hand experience with the hardware, power conditioning, and osiy.

- Investigate the possibility of sponsoring a regional or local WECS demonstration and test program either alone or jointly with the state. One or two WECS units (100kW capacity) may be involved initially.

- Initiate a wind energy survey to identify suitable locations characterized by good wind regimes and close to suitable load centers. A brochure with questionnaire could be sent out with a customer's monthly billing statement, say in the spring when winds are the strongest.

- Determine the suitability of assigning capacity credit to WECS using the utility's own reliability models for determining reserve margin. Evaluate the reduction of conventional electric generating capacity mix (peaking, intermediate, and base-load) with additional amounts of wecs.

- Evaluate the role of load control and energy storage systems in the utility's expansion plans for the 1990's and beyond. Investigate the match between utility/WECS load characteristics and consumer needs. 
- Assess the possibility of installing $10 \mathrm{MW}$ to $20 \mathrm{MW}$ of WECS by the year 1990. A study of the development of the wind machine manufacturing capacity of U.S. industries would give an indication of the cost and availability of wind machines in the coming decade.

The following recommendations are directed toward state agencies (Indiana Department of Commerce, in particular, the Energy Group; and the Public Service Commission of Indiana):

- Participate in the DOE's demonstration and test programs of both small and large wECS.

- Initiate a state-funded demonstration and test program of WECS to complement the federal effort. Small, domesticsized units of capacity less than $10 \mathrm{~kW}$ may be suitable for an initial program.

- Create SWECS incentives, such as property tax exemptions and low interest loans for wECS owners, including utilities. Income tax credits similar to those for active solar energy installations should also be considered.

- Address the problem of the sale of wind generated electricity by non-utilities back to utilities or to third parties.

- Set up a wind survey to identify suitable locations characterized by good wind regimes and close to suitable load centers. The survey in rural areas might be conducted by local farm bureau organizations.

- Conduct on-site wind speed measurements for promising sites in different regions of the state. A microprocessor controlled 
data logging system could record hourly or quarterly-hourly samples of wind speed and direction and any other relevant meteorological parameters. The sensing instruments might be located atop a lom guy-supported tower.

- Form a data base of wind speed time series data. Existing weather bureau records, utility meterological program data, and new on-site wind measurements may be combined to form the data base. 
THIS PAGE

\section{WAS INTENTIONALLY \\ LEFT BLANK}


1. Dewinke1, Carel C., An Assessment of Wind Characteristics and wind Energy Conversion Systeins for Electric Utilities, IES Report 104, University of Wisconsin, Madison, January 1979.

2. JBF Scientific Corporation, Wind Energy Systems Application to Regional Utilities, Final Report, U.S. ERDA Contract No. EX-76-C-01-2438, U.S.DOE, Washington D.C., May 1979.

3. Ligon, Cleon, et. al., Southwest Research Institute, Operational, Cost, and Technical study of Large Windpower systems Integrated with an Existing Electric Utility, Final Report, SwRI Project 15-4242, National Technical Information Service (\#COO-2621-2). Springĩield, Virginia, April, 1976. 
THIS PAGE

\section{WAS INTENTIONALLY \\ LEFT BLANK}


REFERENCES FROM DEWINKEL CITED IN THIS REPORT

Changery, Michael J. 1975. Initial wind energy data assessment study. NSF-RA-N-75-020. U.S. Dept. of Commerce. NOAA. Environmental Data Service. National Climatic Center. May. 125pp.

Eldridge, Frank R. 1975. Windmachines. Report prepared for NSE; research applications directorate; RANN Grant No. AER-75-12937. The Mitre Corporation. October. 76 pp.

Garate, John A. 1977. Wind energy mission analysis final report. Summary and Appendices A through J. ERDA Contract No. EY-76-C-02-2578. Space Division, General Electric Company, Philadelphia, DA. February 18.

General Electric Comp. Mis'sion Analysis. See Garate 1977.

Golding, E. W., and Stodhart, A. H. 1952. The selection and characteristics of wind power sites. Electrical Research Association Report C/T 108. Cleeve Road Leatherhead Surrey KT 22 7SA England.

JBF Scientific Corporation. 1977a. Summary of current cost estimates of large wind energy systems. Contract No. E (49-13)-2521. ERDA, Division of Solar Energy. February.

- 1977b. Third wind energy workshop, volume 1 and 2. Proceedings of the Third Biennial Conference and Workshop on Wind Energy Conversion Systems. Washington, D. C. Sponsored by DOE. September 19-21.

Johanson, Edward E., and Goldenblatt, Martin K. 1977. Assessment of the potential for using large wind turbines in New England. In: JBF 1977b. September. pp. 222-236.

Justus, C. G., and Mikhail, Amir. 1976. Height variation of wind speed and wind distribution statistics. Geophysical Research Letters. vol. 3, No. 5. May. pp: 261-264.

Kung, Ernest C., and Lettau, Heinz H. 1961. Regional and meridional distributions of continental vegetation cover and aerodynamic roughness parameters. Annual Report 1961, Section 5. "Studies of the 3-D Structure of the Planetary Boundary Layer." University of WiscunsinMadison, Department of Meteorology.

Lettau, H. H., and Haugen, D. A. 1957. Wind. Chapter 5 in Handbook of geophysics for Air Force designers. First edition, GRD, Air Force Cambridge Research Center. (Later reprinted by McMillan Comp.). 
Marsh, W. D. 1978. Utility applications of wind power plants. Prepared for the 5th energy technology conference, Washington, D. C. February 27. Electric Utility Systems Engineering Department, G. E. Company, I River Road, Schenectady, New York 12345.

Melton, Walter C. 1977. Loss of load probability and capacity credit calculations for WECS. In: JBF 1977b. September. pp. 728-741.

Reed, Jack W. 1975. Wind power climatology of the United States. Sand 74-0348, Sandia Laboratories. June $159 \mathrm{pp} . .$.

- 1976a. Meteorological studies for wind power. Progress report for the period May-October 1976. ERDA-5443. Sandia Laboratories, Albuquerque, New Mexico 87115. November.

- 1976b. Predicting wind power at turbine level from an anemometer record at arbitrary height. NTIS-SAND-76-5397. Sandia Laboratories, Albuquerque, New Mexico 87115. 10 pp.

Tagg, J. R. 1957. Wind data related to the generation of electricity by windpower. Electrical Research Association Report C/T 115. Cleeve Road, Leatherhead, Surrey KT22 7SA, England.

Takle, Eugene S., and Brown, John M. 1976. Wind and wind energy in Iowa. Final report to the Iowa Energy Policy Council. Iowa Ag. and Home Econ. Exp. Station. Iowa State University, Ames, Iowa 50011. October, 1. 125 pp. 
APPENDIX A

Wind Speed and Power Density for Indianapolis, 1973-77 
THIS PAGE

WAS INTENTIONALLY

LEFT BLANK 
Average wind speed (meters per second) and power density (watts per square meter) for Indianapolis are plotted by hour of day and phase of year for the five-year period 1973-1977. The wind speed was measured at an anemometer height of $6.1 \mathrm{~m}$ (20 feet) for the duration of the period. The long-term average annual wind speed for Indianapolis at that height is $4.34 \mathrm{~m} / \mathrm{s}(9.7 \mathrm{mph})$. 


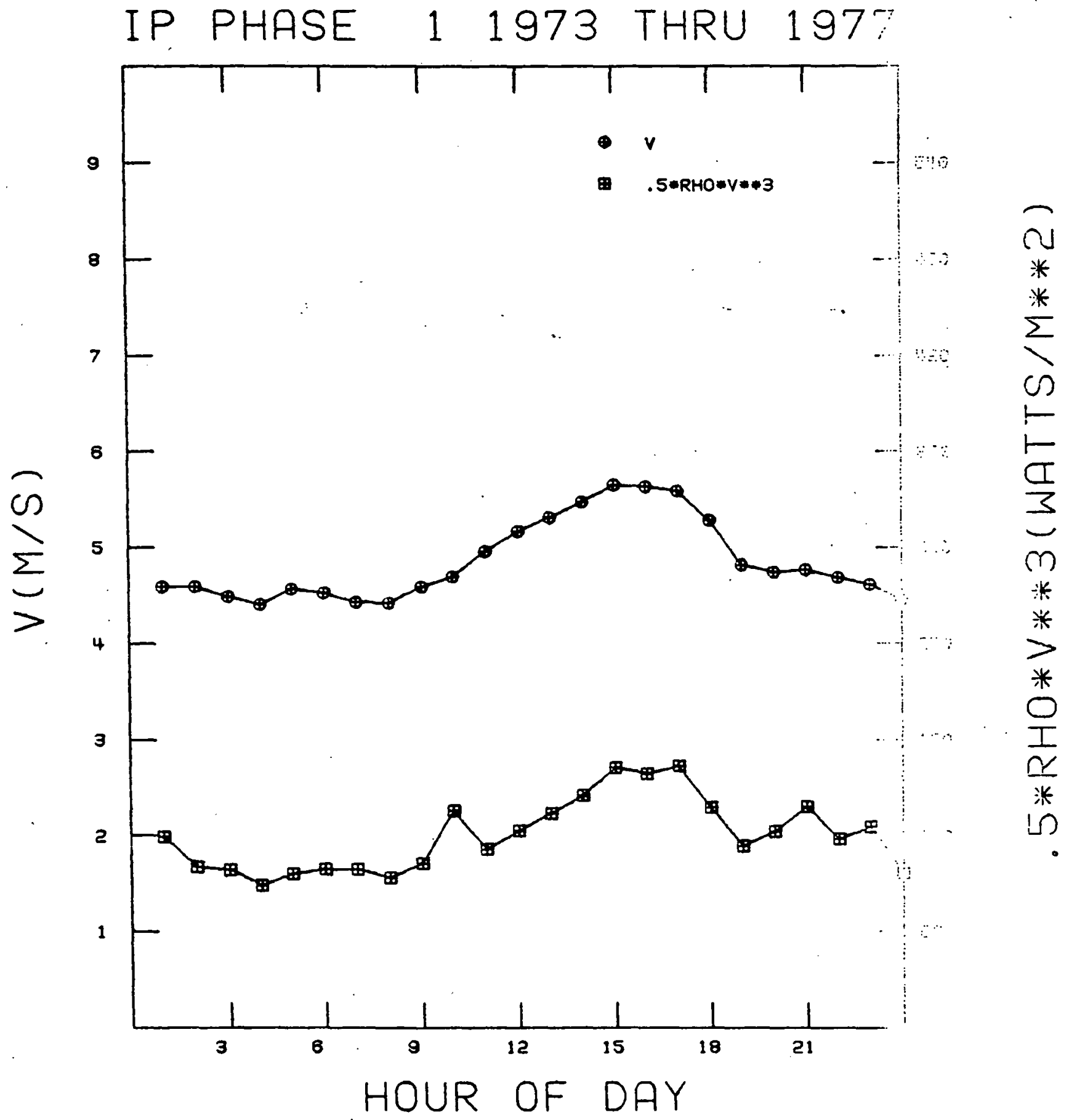




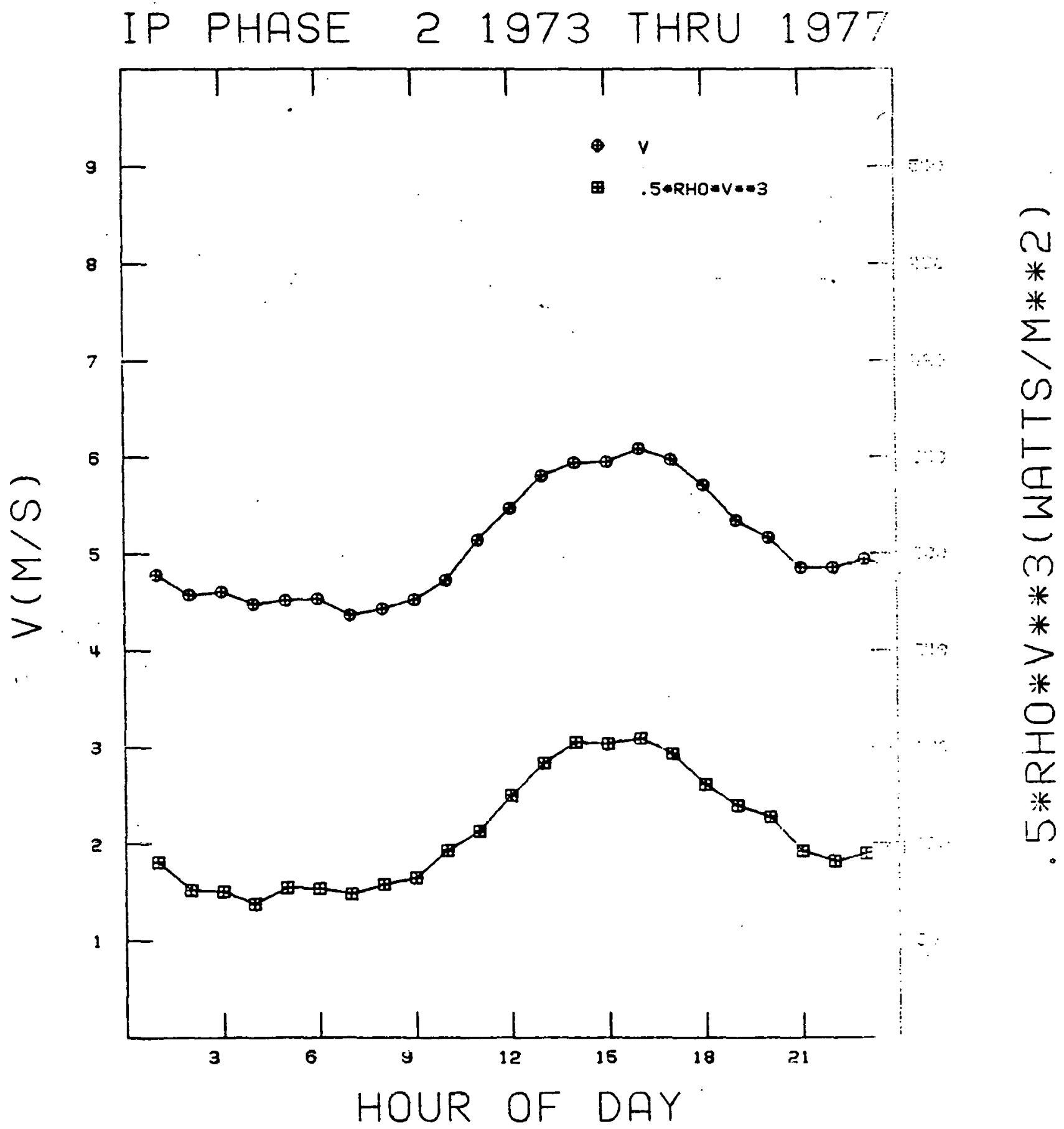




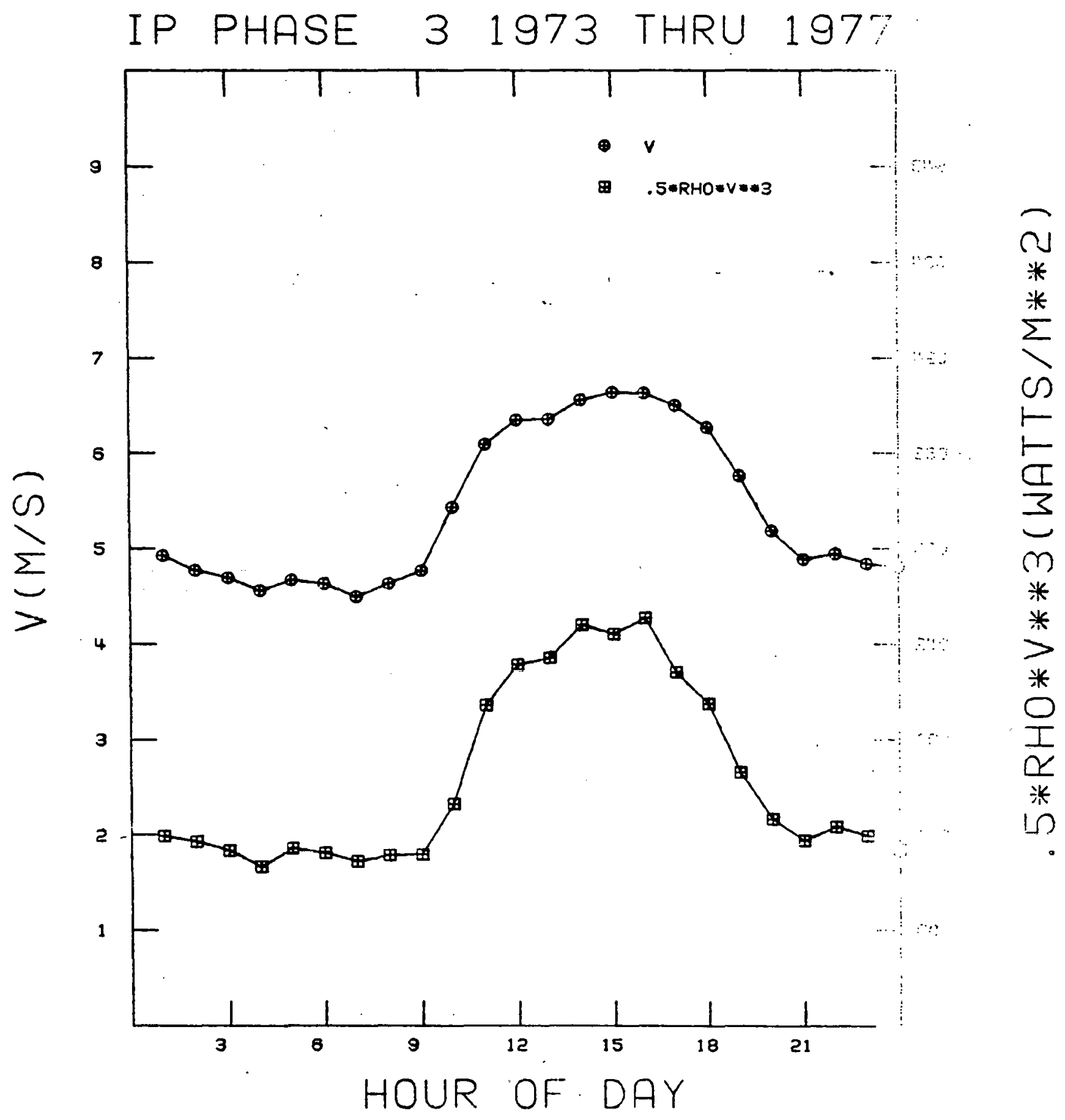




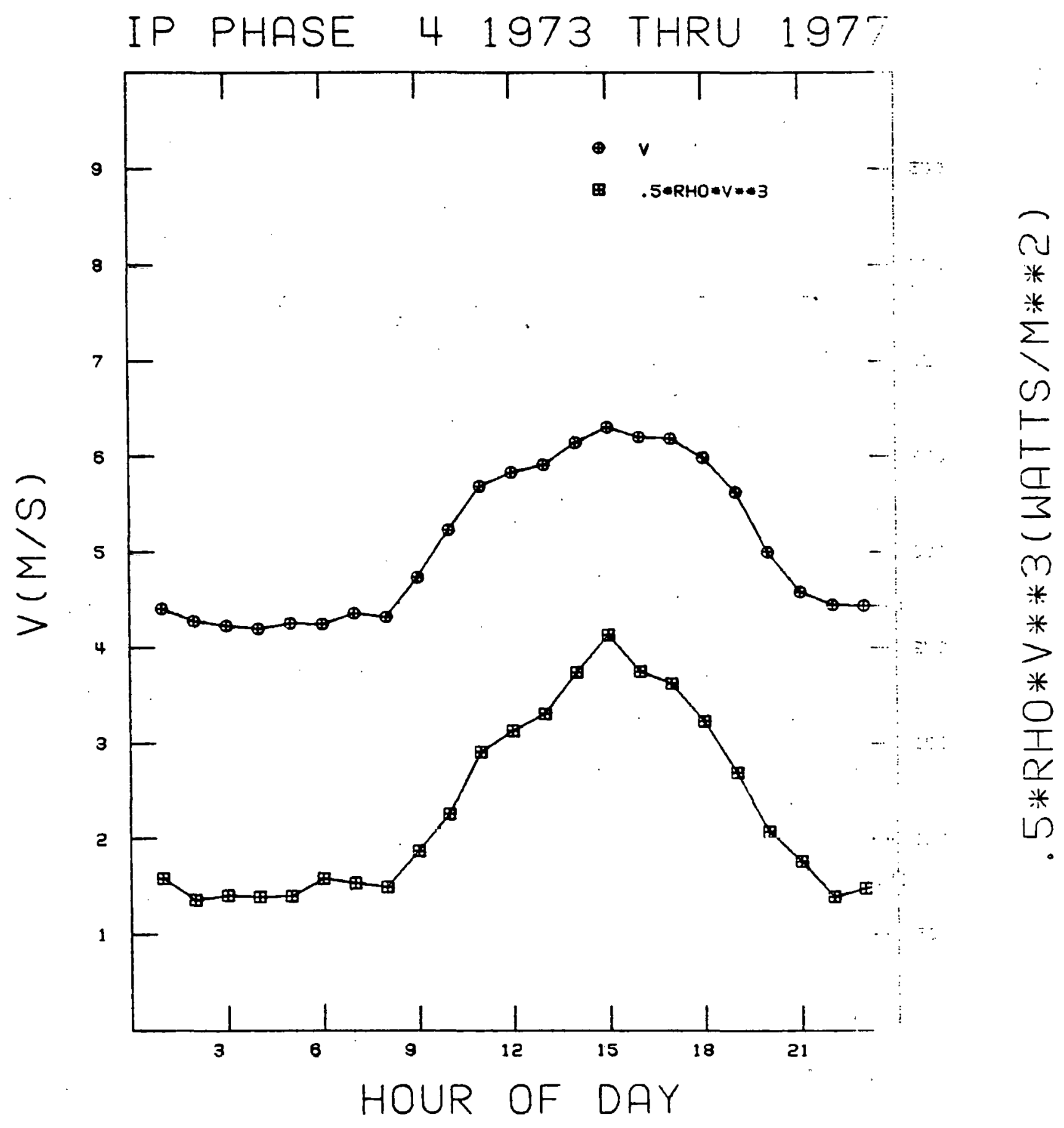




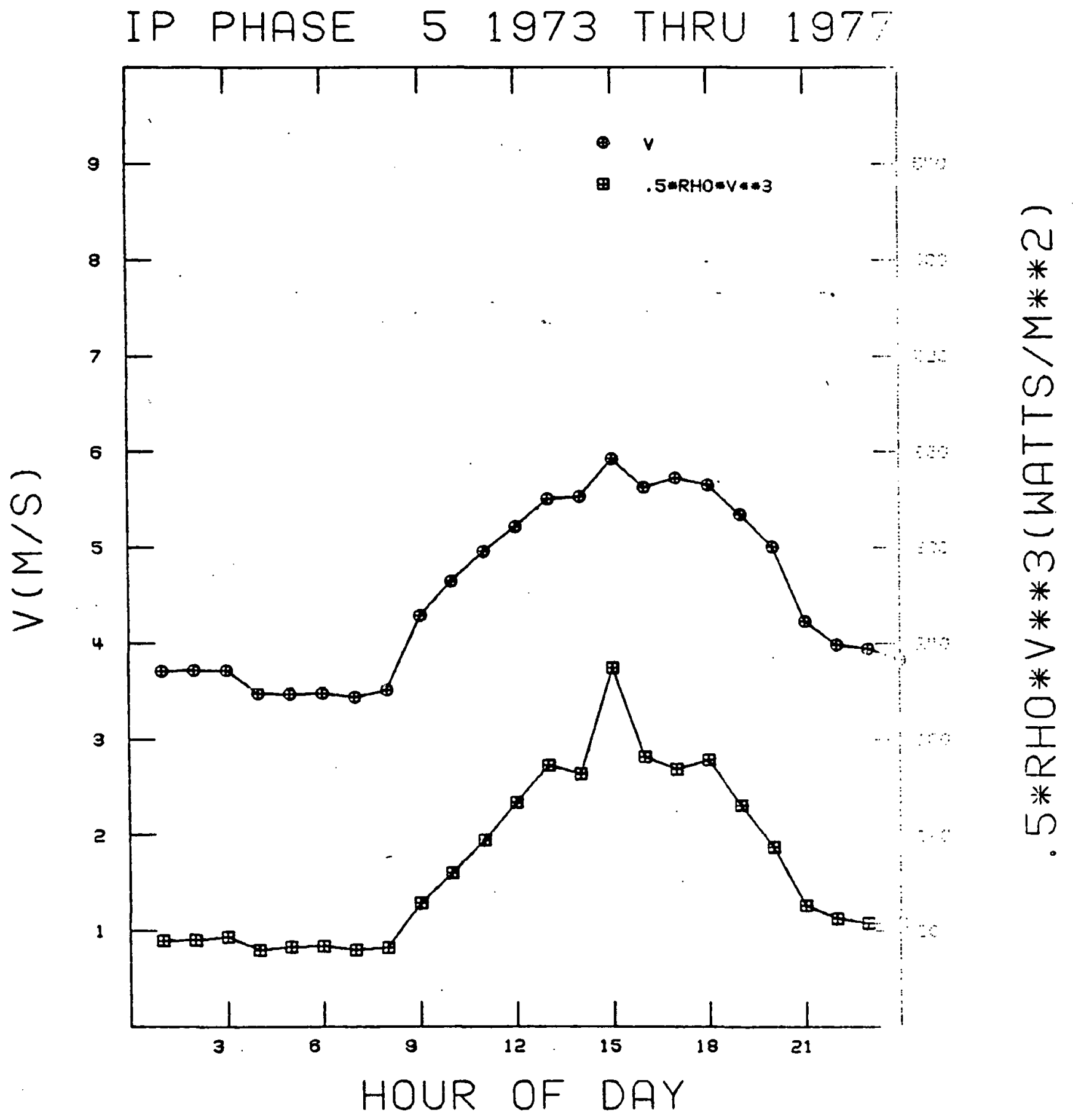




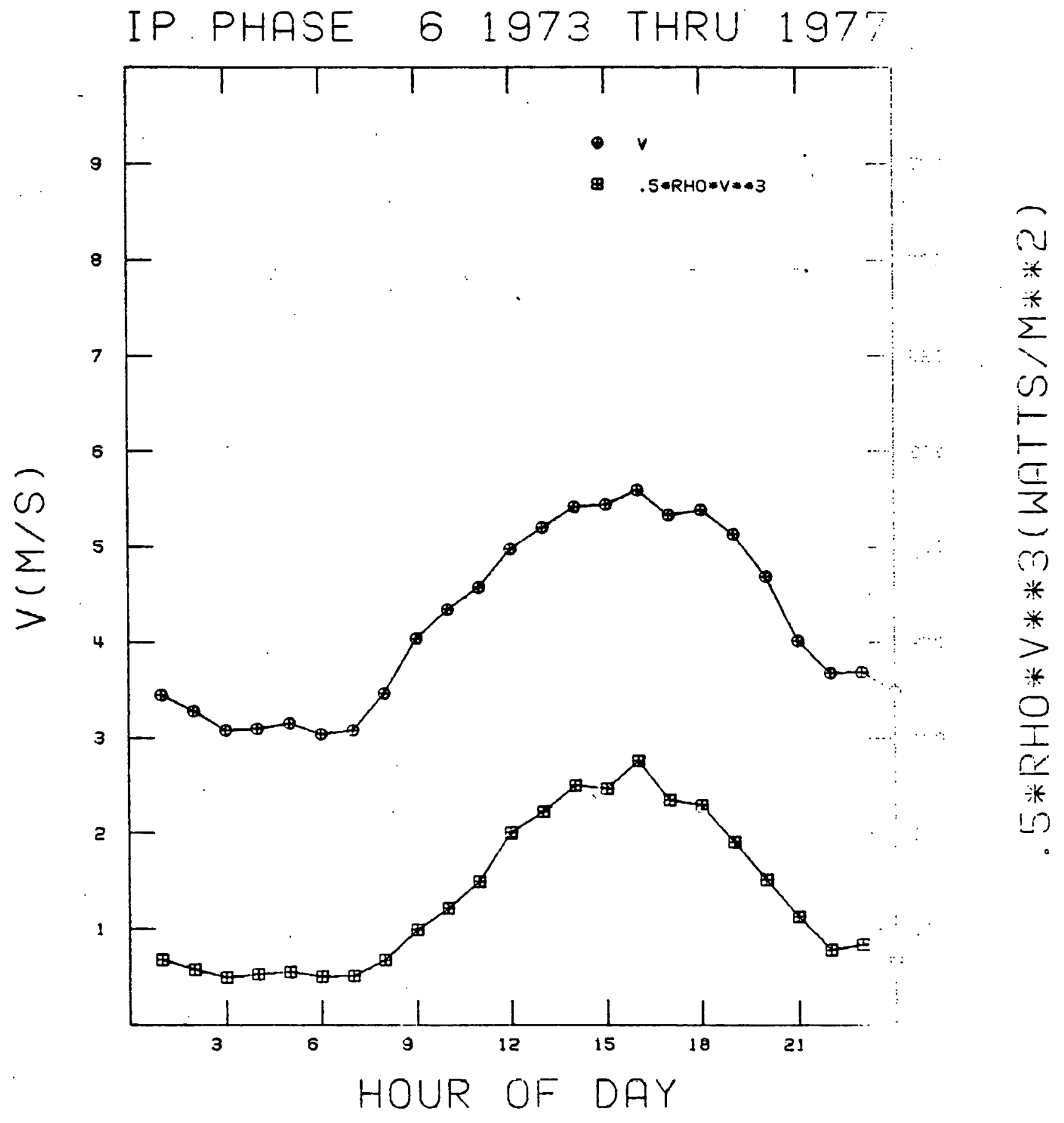




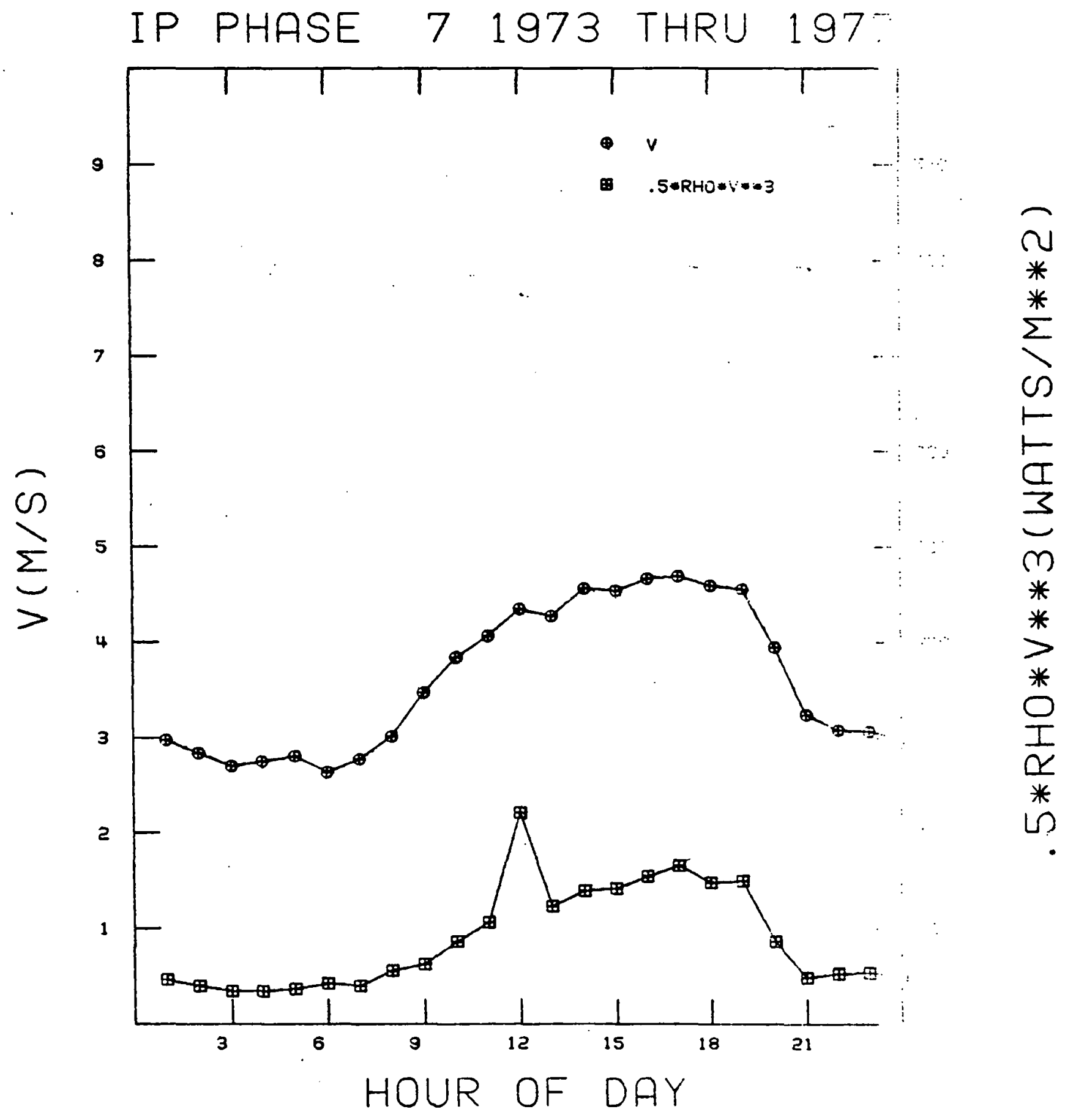




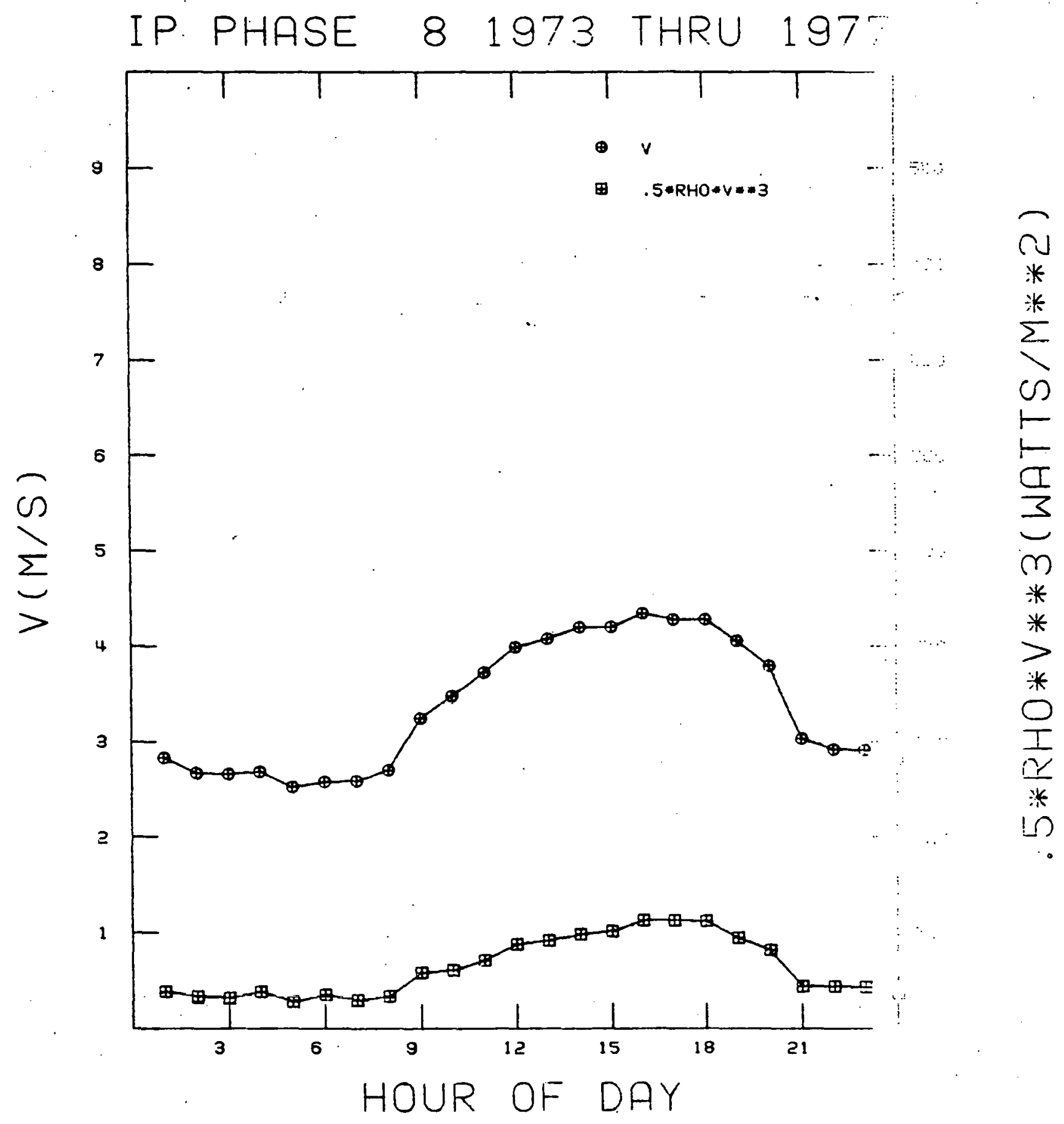




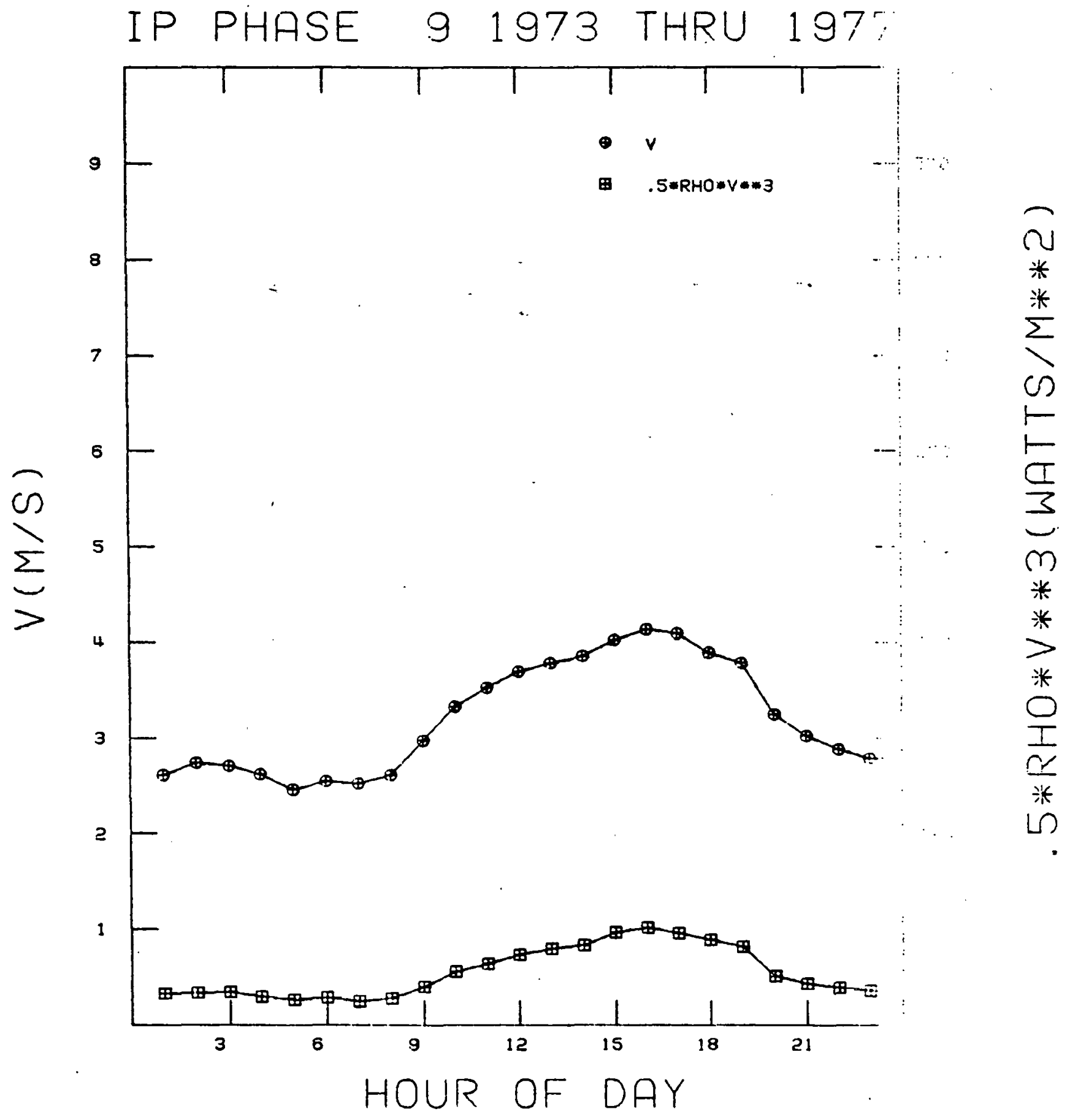




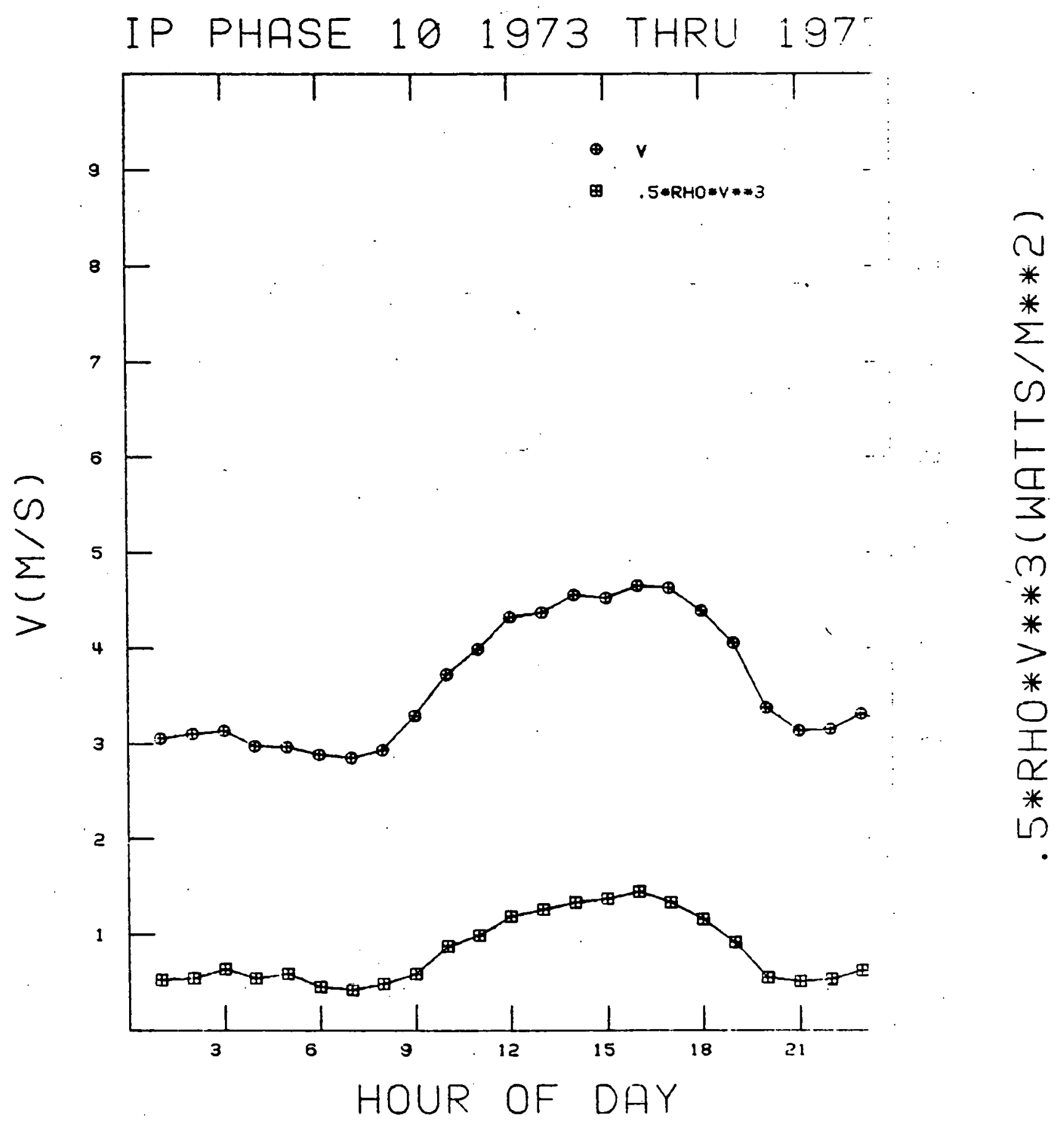




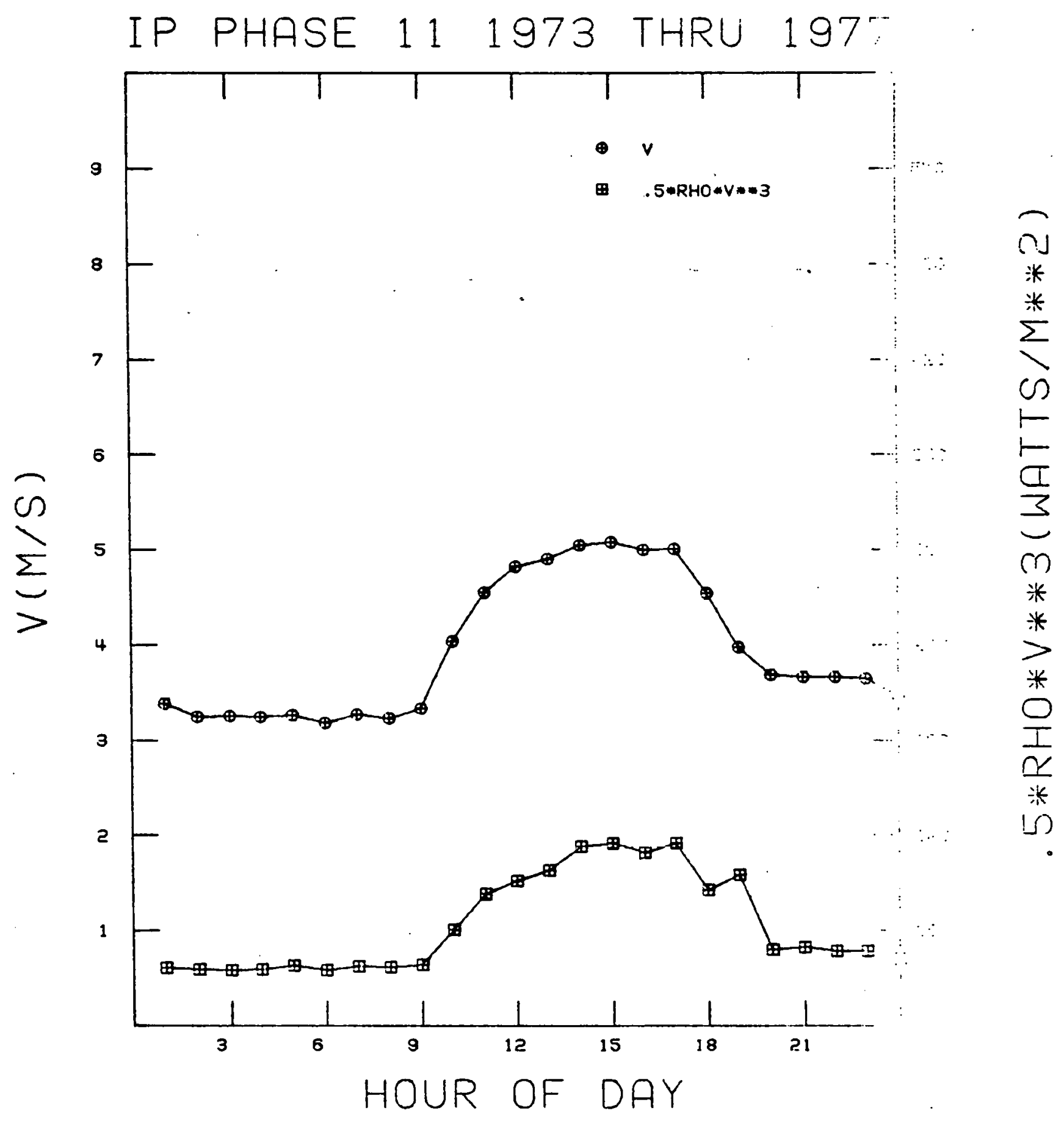




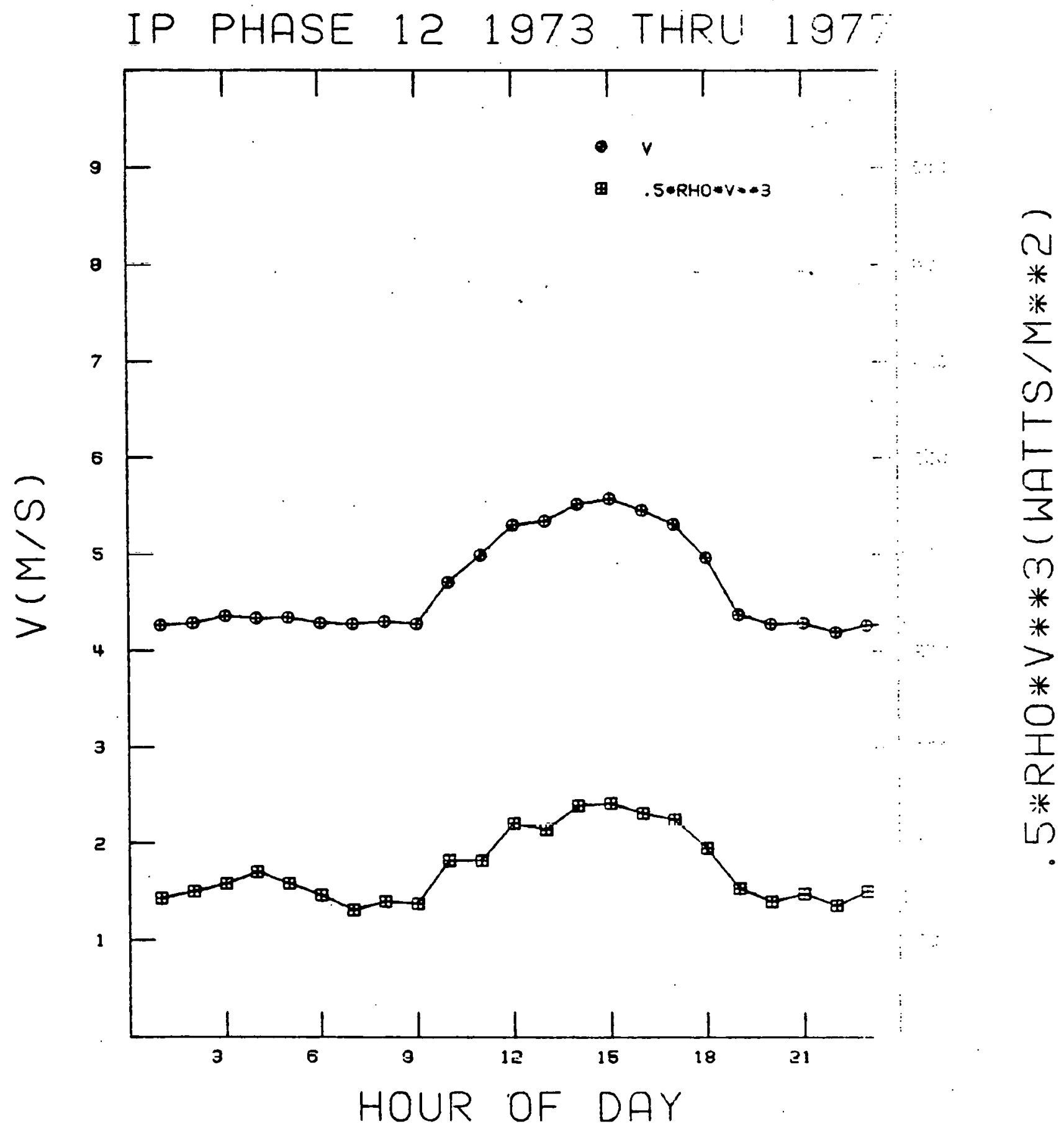




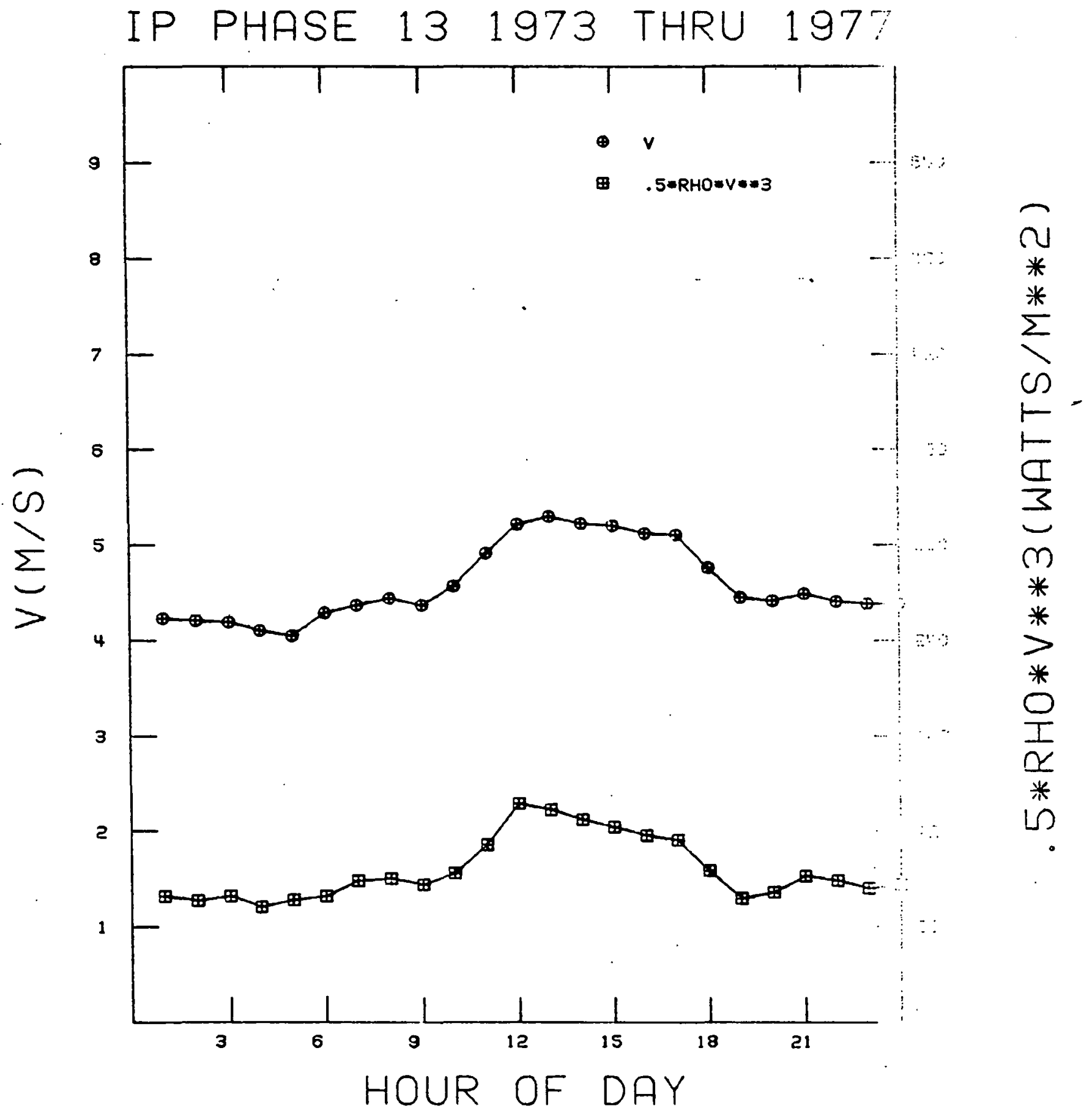




\section{APPENDIX B \\ Public Service Indiana's Load for 1979}




\section{THIS PAGE \\ WAS INTENTIONALLY \\ LEFT BLANK}


This appendix contains plots of Public Service Indiana's average load in megawatts by phase and hour of day for the year 1979 . The day, hour, and magnitude of the peak load for the phase is indicated in the upper right-hand corner of each plot. The annual peak load in 1979 was 3488 MW, occurring on January 15 at 3:00 a.m. 


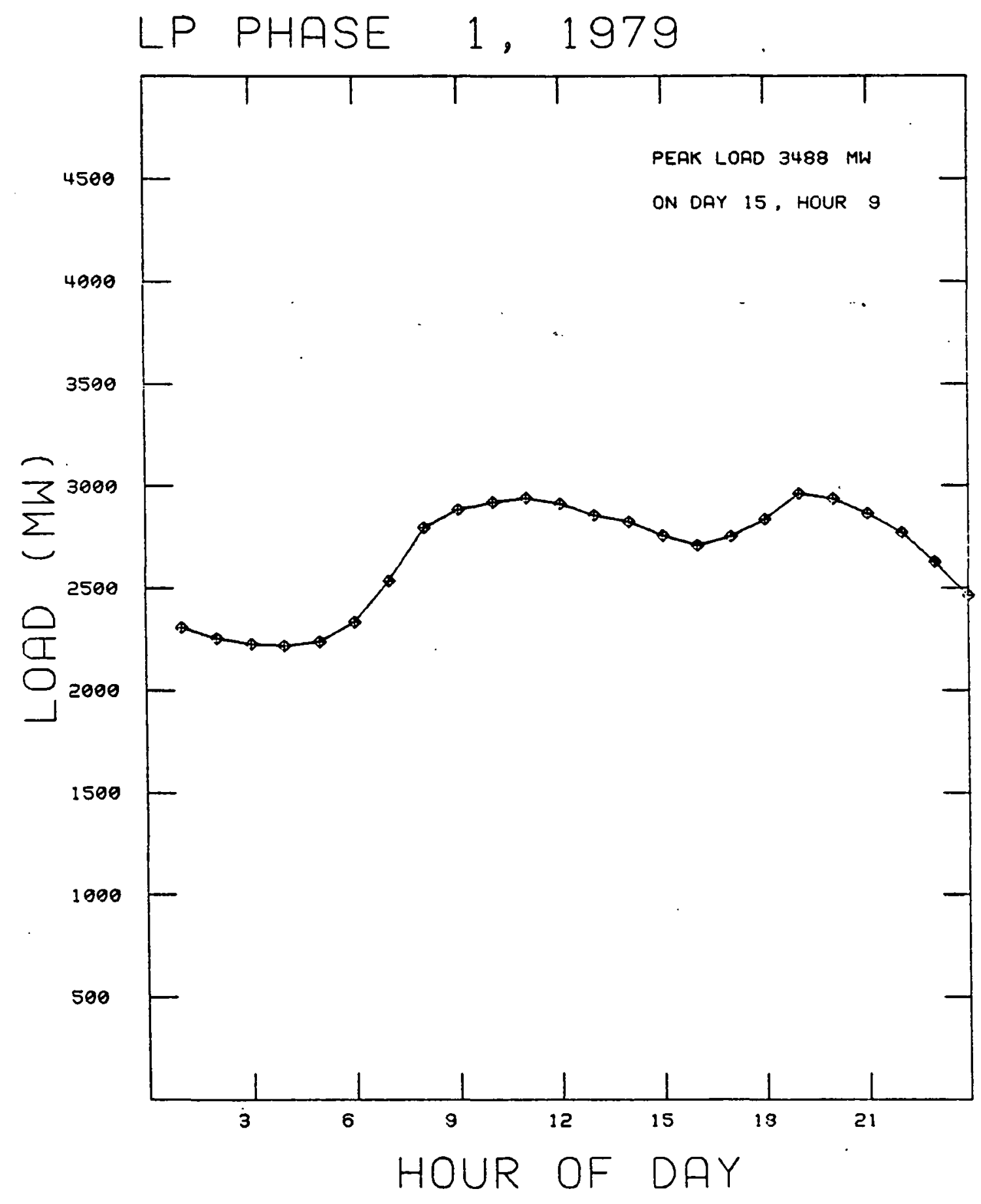




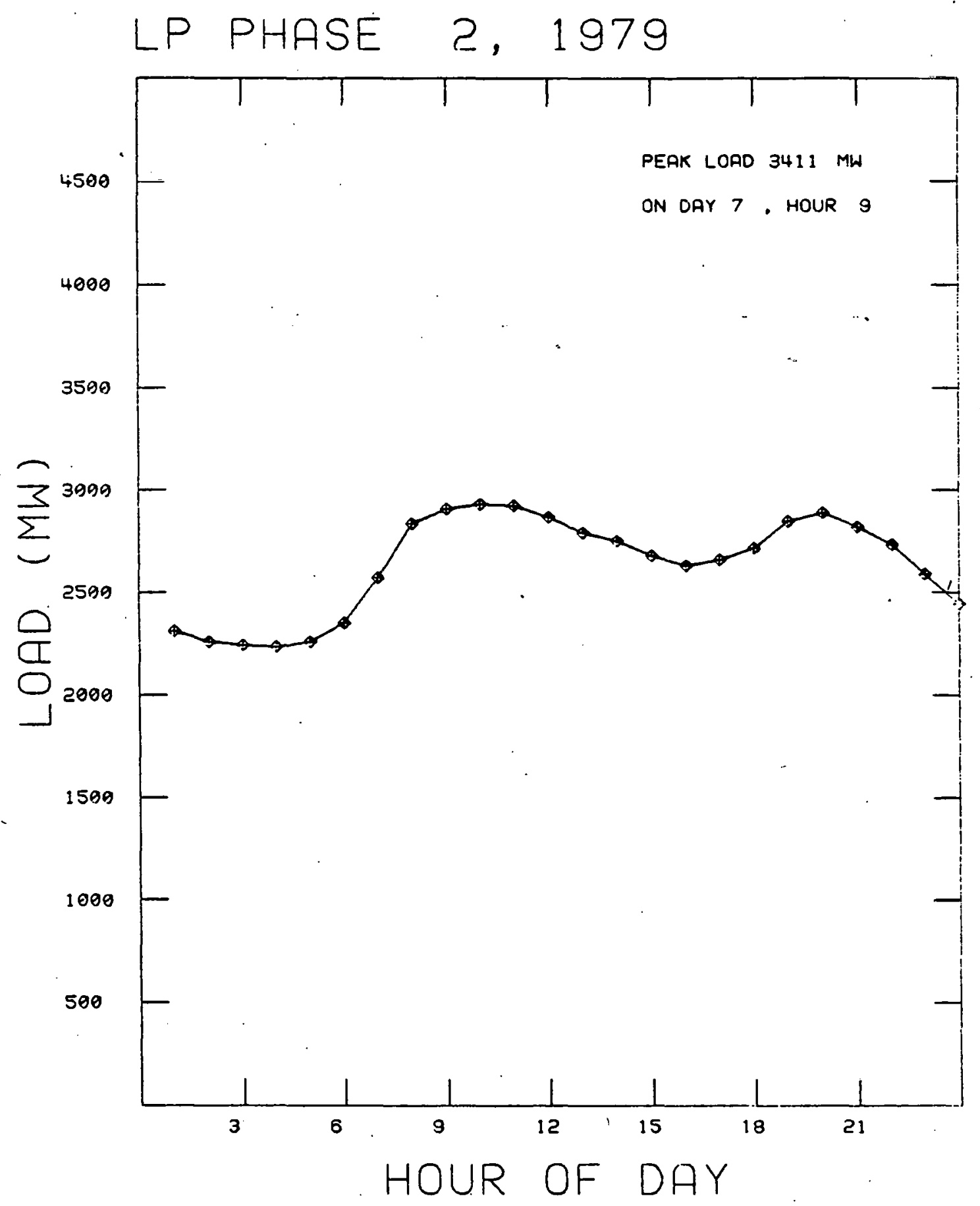




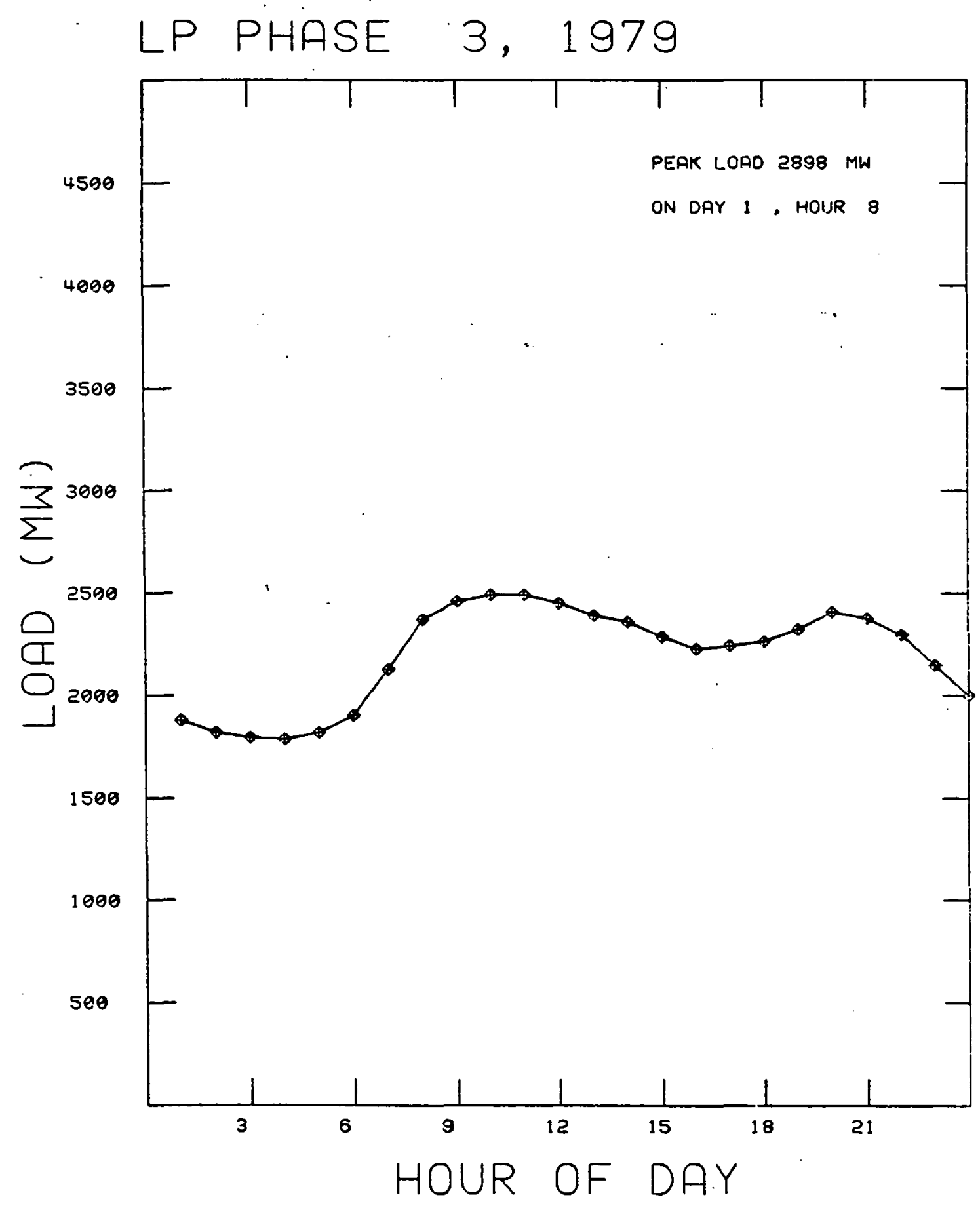




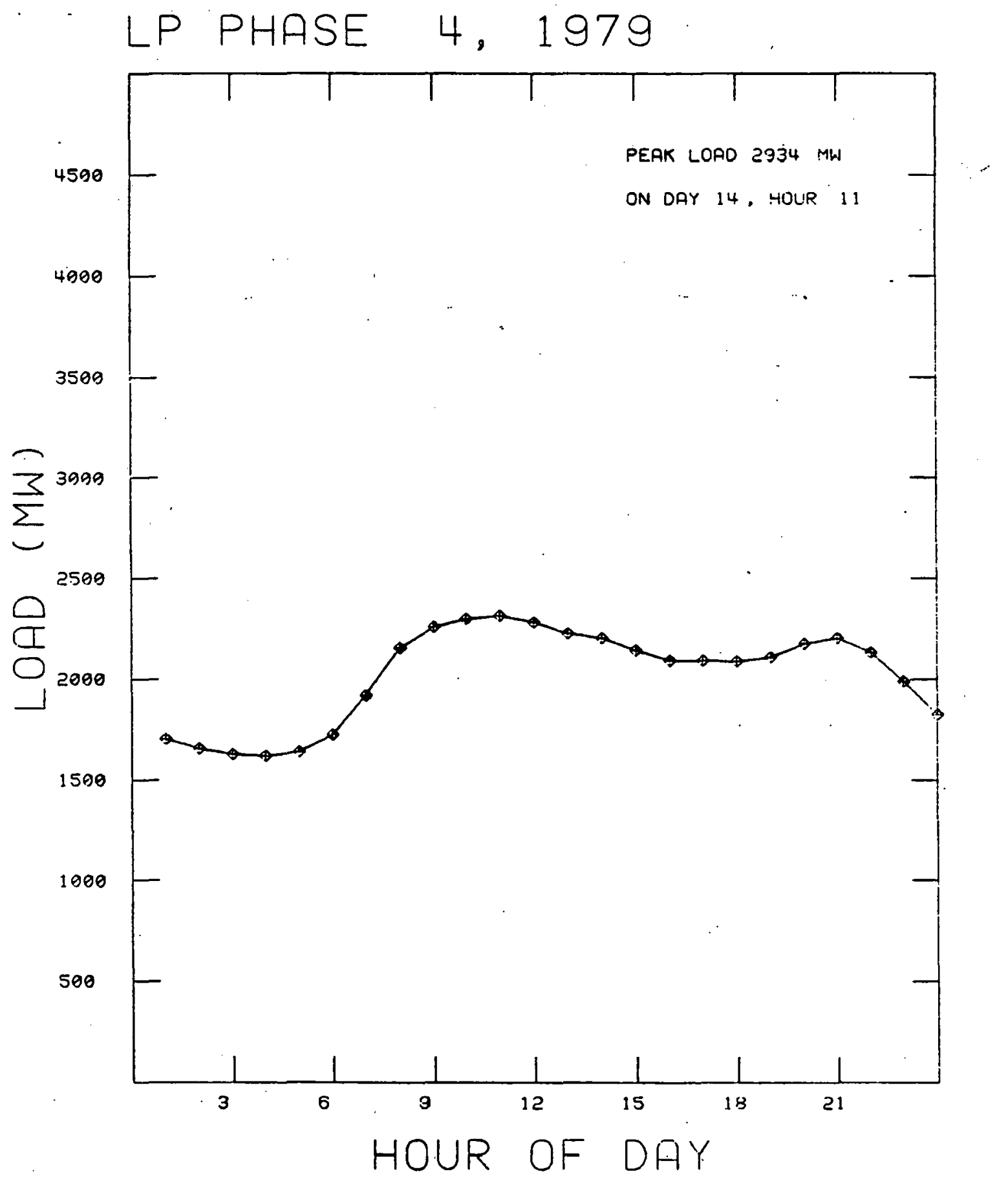


LP PHASE 5, 1979

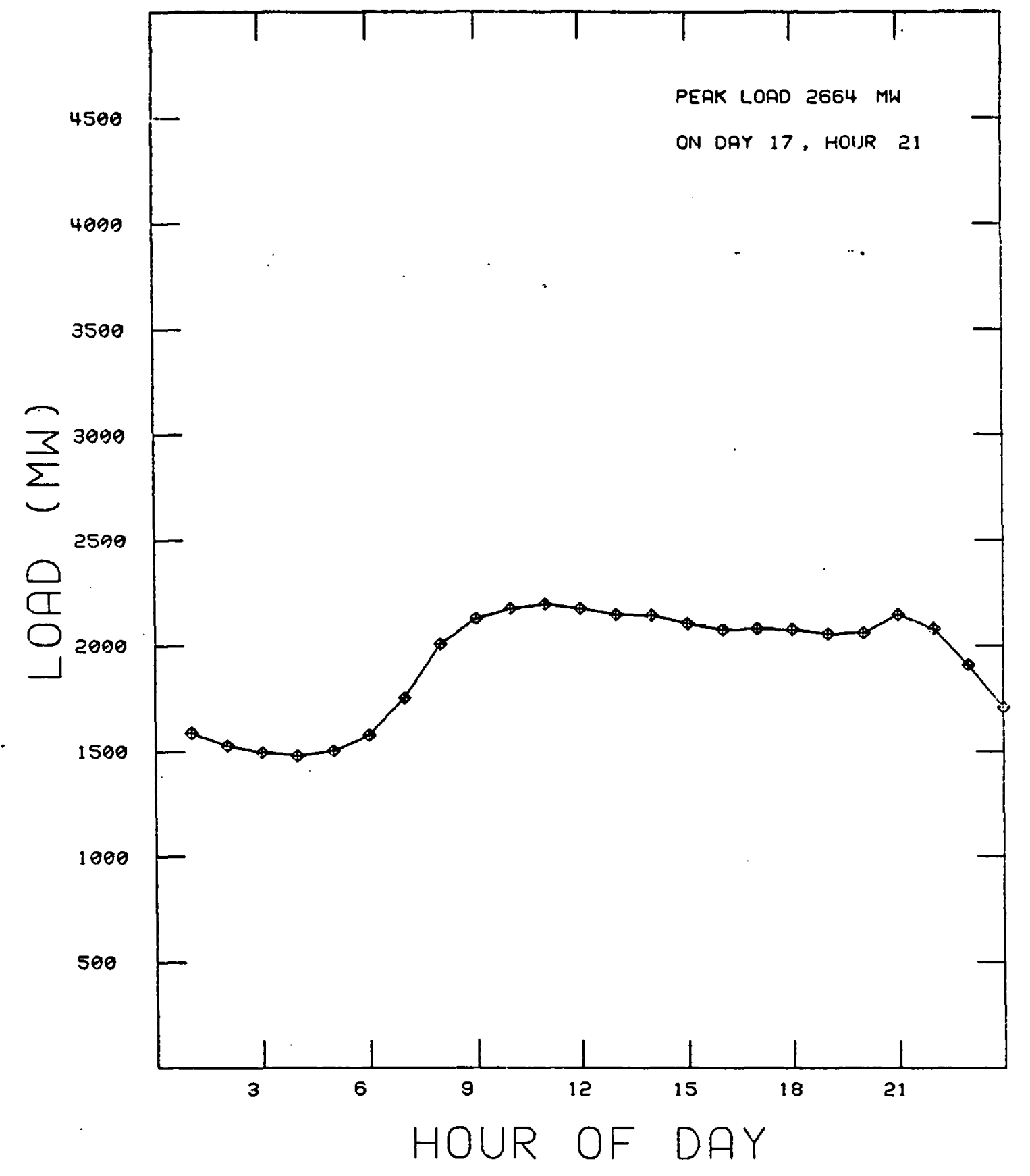




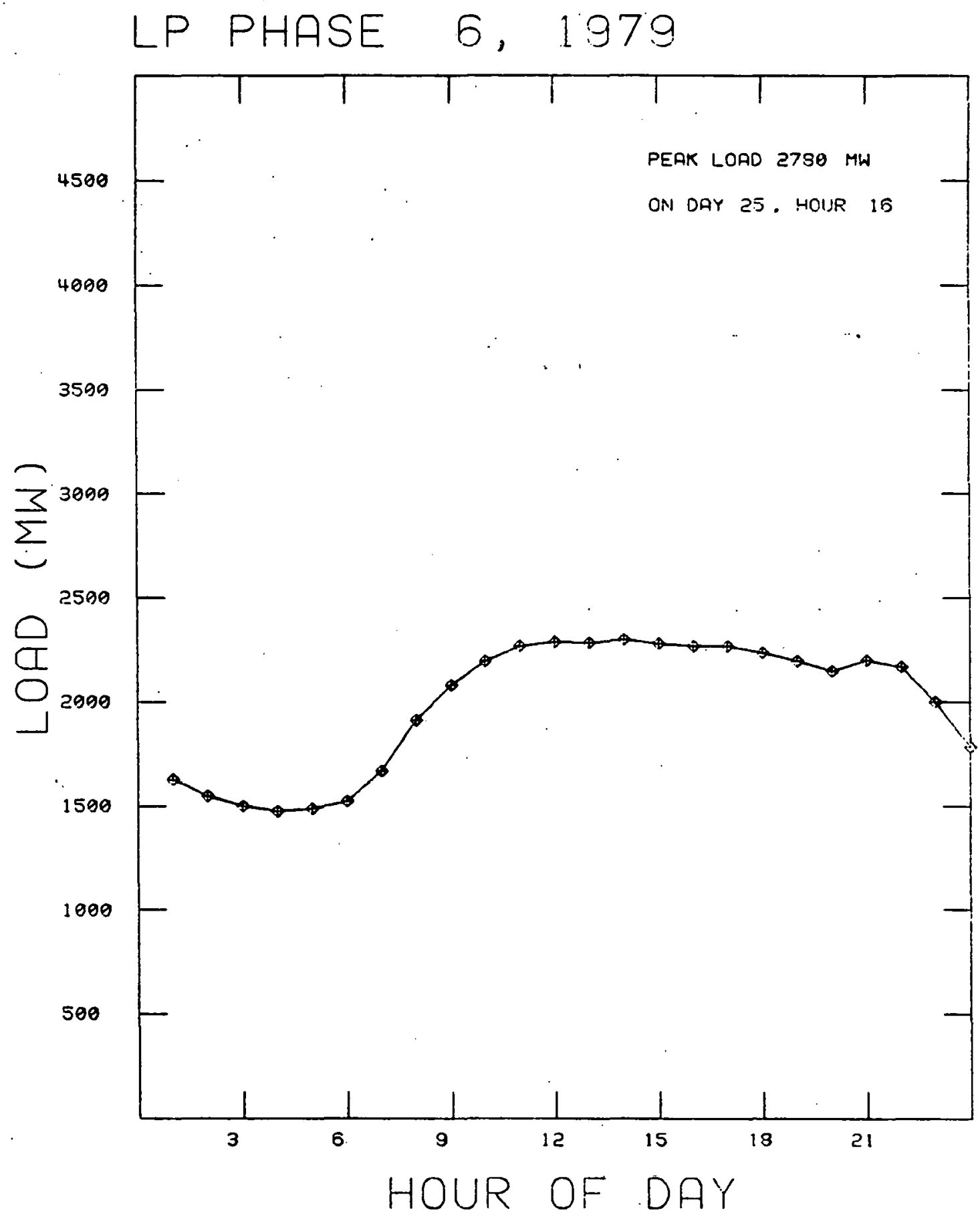




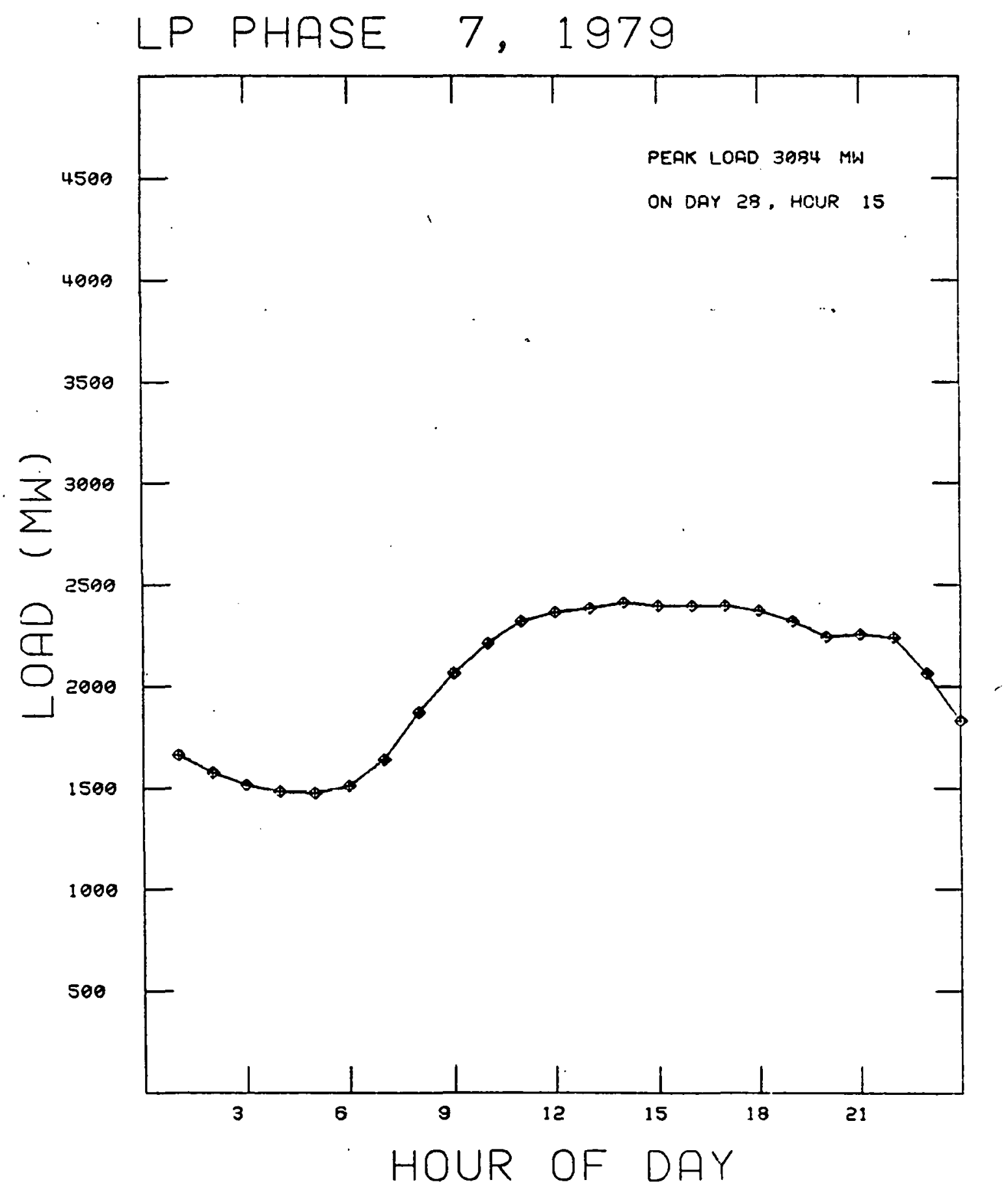




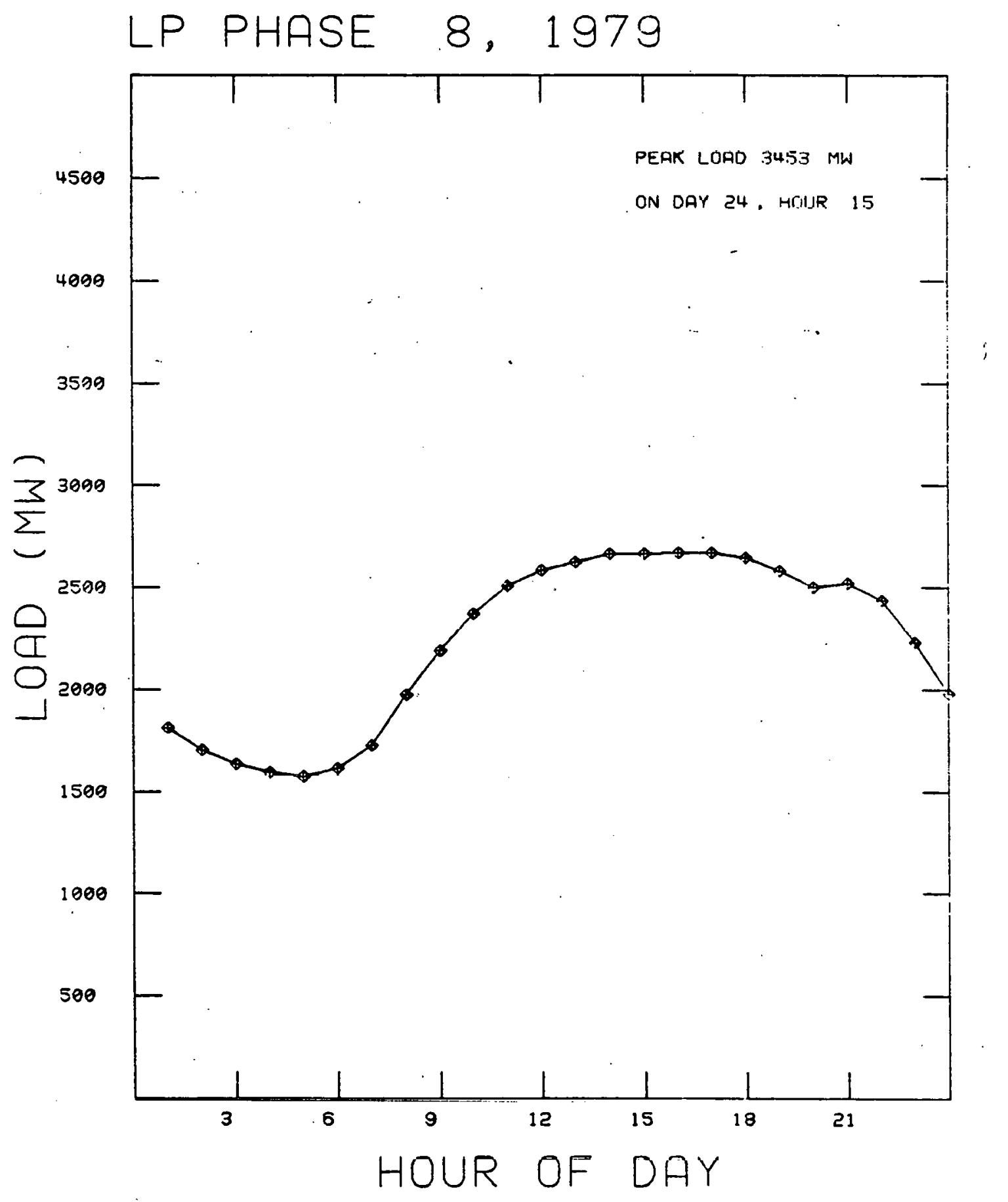




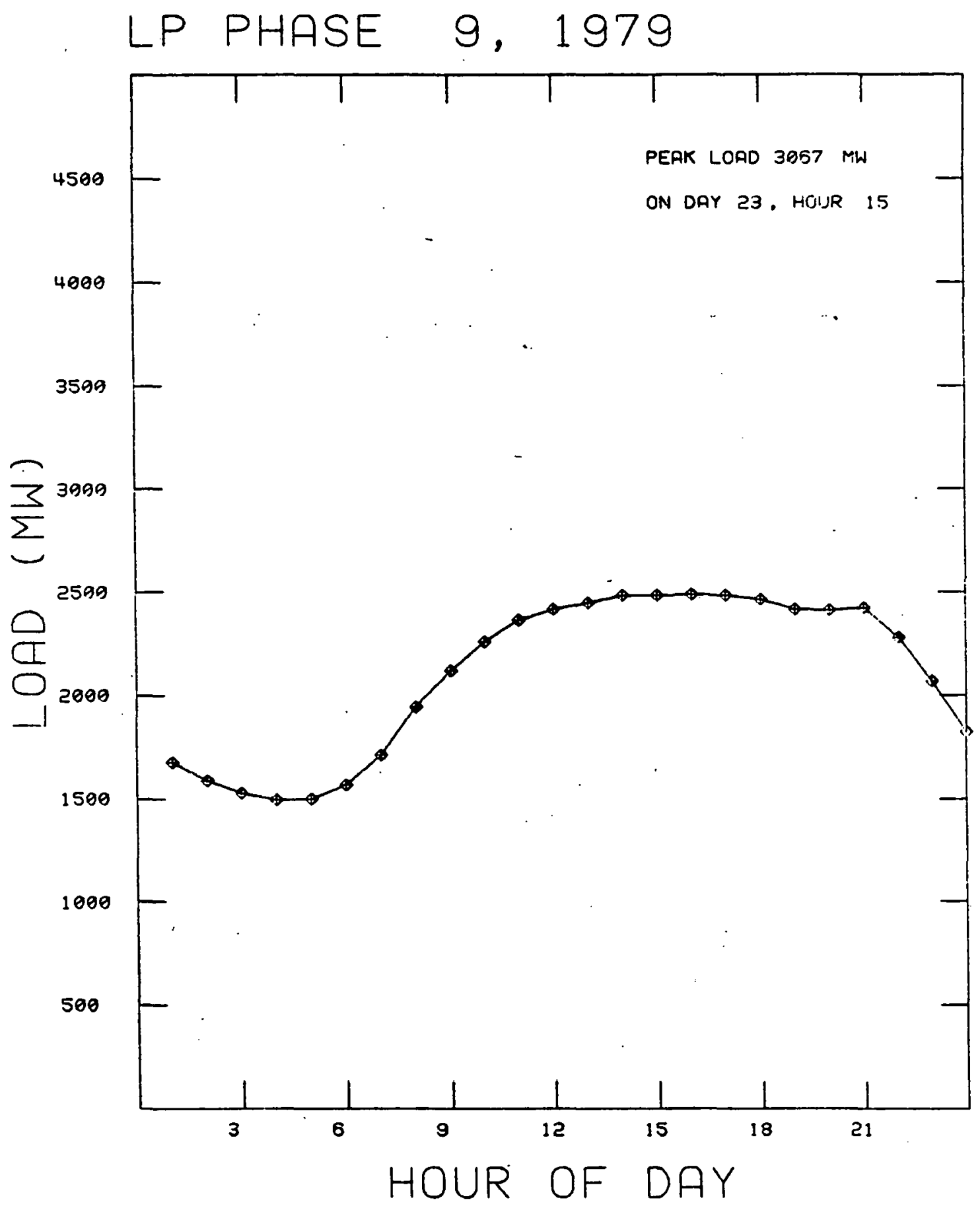




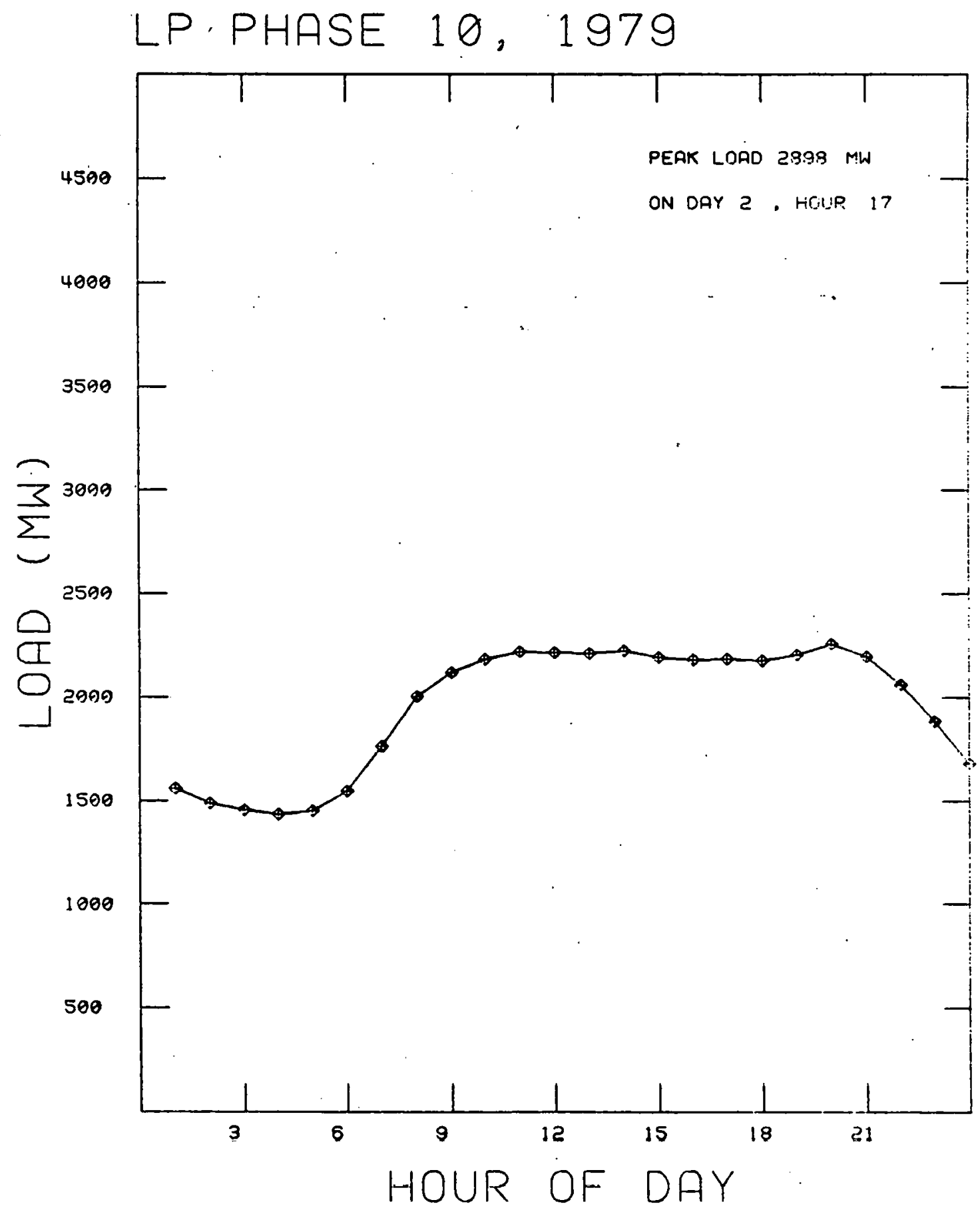




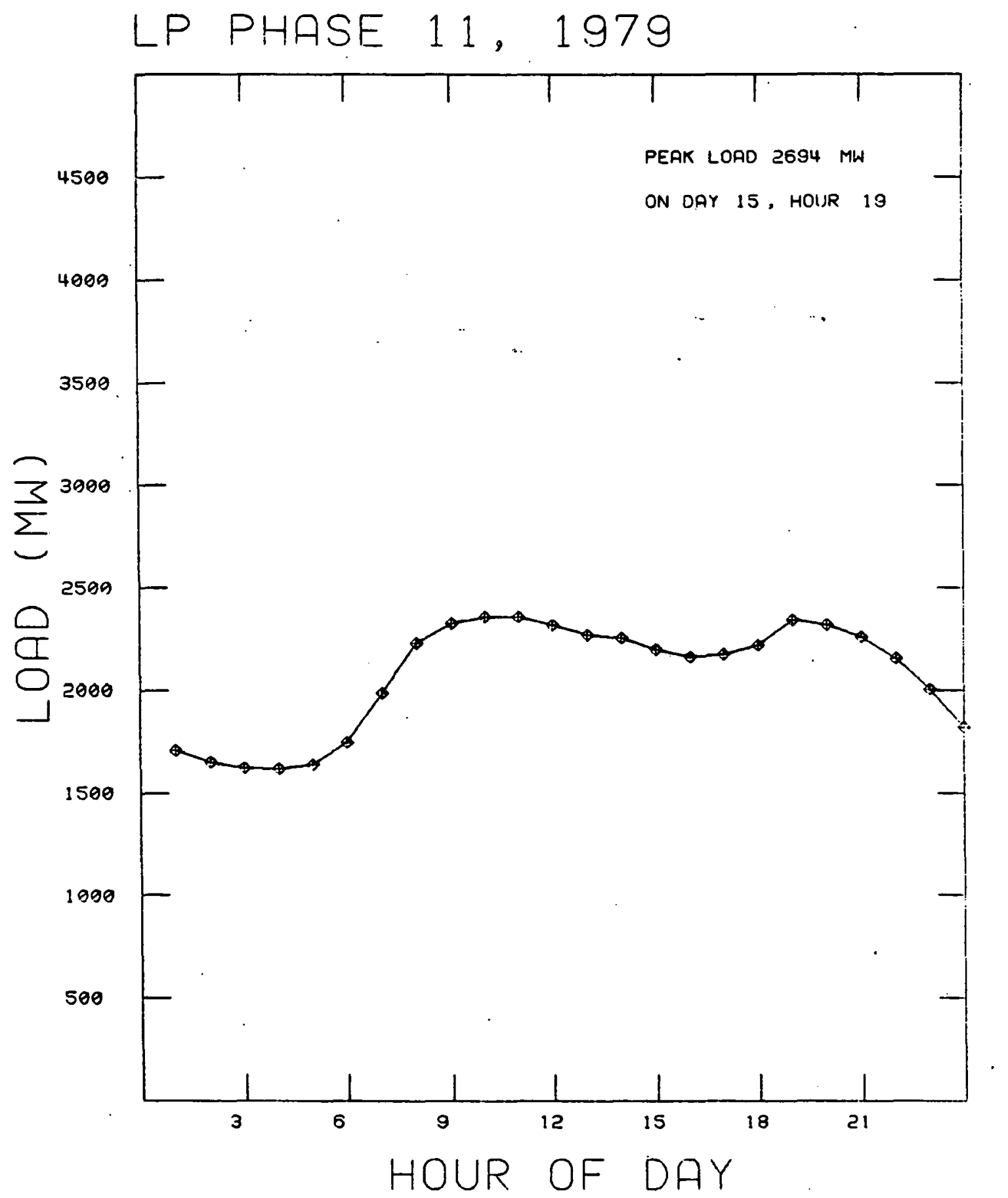




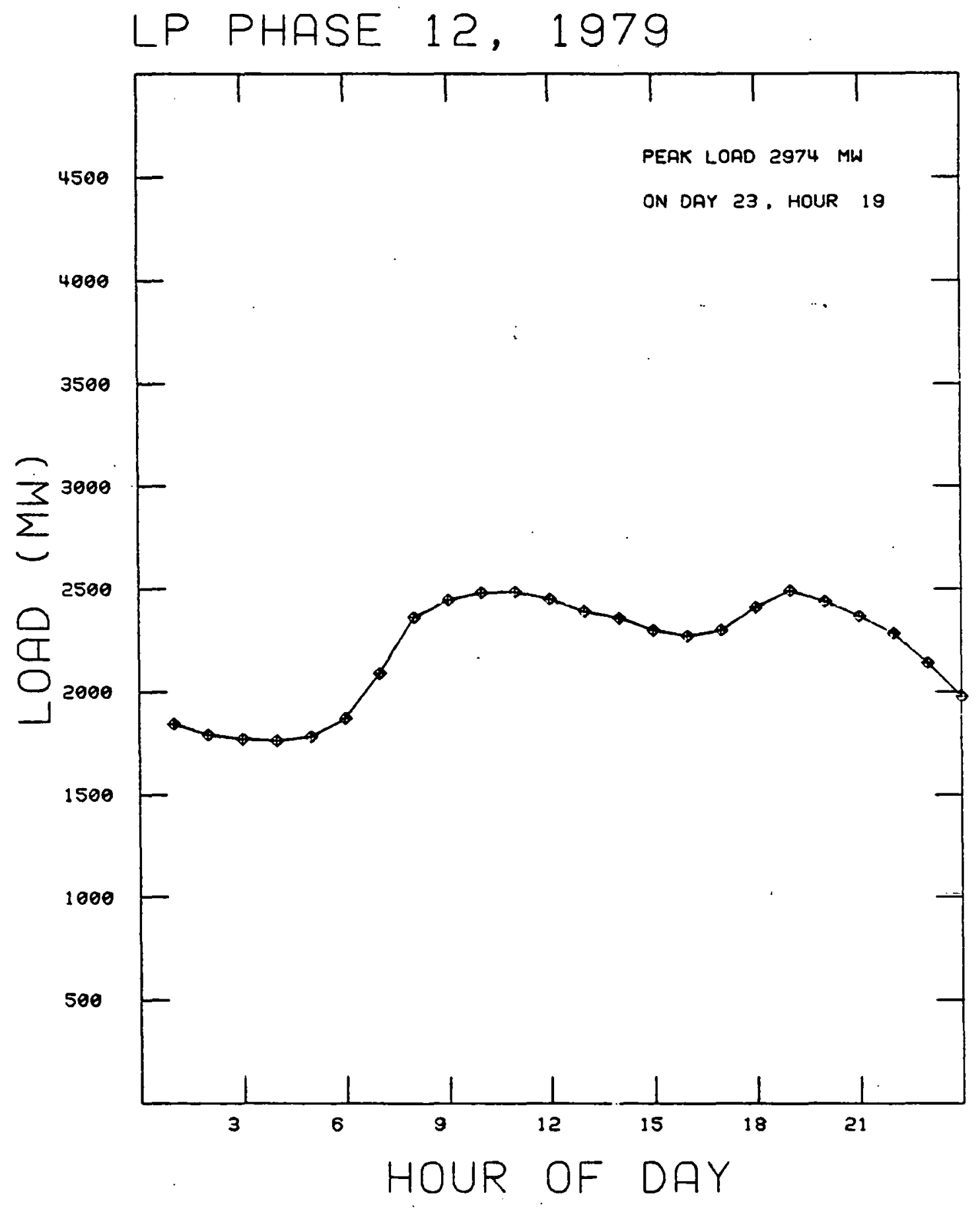




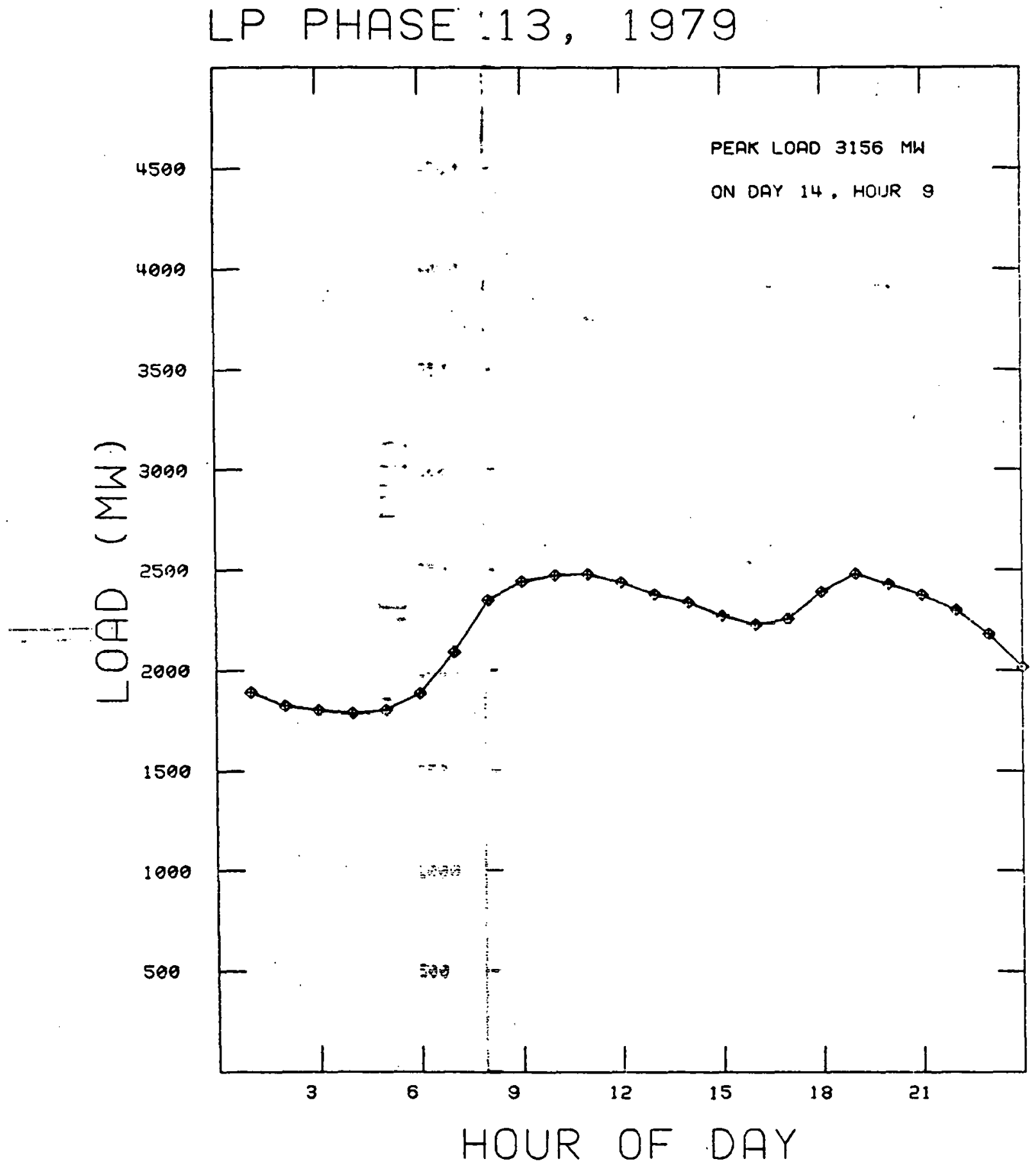


APPENDIX C

JBF Computer Programs 
THIS PAGE

\section{WAS INTENTIONALLY \\ LEFT BLANK}

$2 / 6$ 
The following description of the JBF computer programs is drawn from the introduction to volume II of the JBF report.]

A methodology for analyzing the economic impact of WECS on a utility is described in volume I of this report.... The methodology requires extrapolating both historical utility load data and historical wind power into a year of analysis; calculating the total number of funds made available in that year, as a result of the inclusion of wind power in the utility mix; and then estimating the present value of the total funds made available to the utility over the life of the WECS. By repeating the anslysis for various WECS power levels, the present value of the funds made available to the utility over the life of the WECS as a function of WECS penetration can be defined. The derivative of that function at any single power level represents the life-cycle marginal available funds that are generated by the addition of the next wECS unit to the utility equipment mix. By equating the present value of the life-cycle marginal available funds to the present value of the life cycle costs associated with purchasing a WECS, the amount of funds available for the purchase of the next WECS unit itself can be identified. When such unit available funds are compared to a manufacutrer's schedule of wECS costs, it is possible to identify the wECS penetration level that will minimize utility production costs.

To apply the above methodology to a specific case, it was necessary to develop various computer programs.... Table c-l lists the programs... and explains each program's function. 
Historical wind data is first submitted to the SERIES program which evaluates by phase and hour mean wind speed, standard deviation of wind speed, mean wind power, wind speed distribution, and wind power probabilities for both a single site and a typical site in a WECS array. The WINDS program is designed to generate any missing wind speed data by spacial and chronological interpolation of the output of SERIES. Program WINDS evaluates by phase and hour the mean wind speed, standard deviation of wind speed, mean wind power, wind speed distribution and wind power probabilities for a typical site in a WECS array. The representative hourly loads, for a specific year, are created from historical load data by programs PHASES and AVERAGE. Program NETLOAD both projects the representative utility loads and defines the expected hourly wind power in the year of analysis.

By subtracting the expected WECS power from the projected utility load the modified load that must be satisfied by the utility's conventional generating sources can be defined. The modified loads can then be used by a utility to define a new optimum mix of conventional equipment, that takes into account the availability of WECS power. Any reduction in capital expenditures as a result of the new equipment mix is credited to WECS as a cost savings. The selected optimum equipment $\mathrm{mix}$ and its associated economic and operational parameters are used in program GENSYS to commit equipment for dispatching, based on incremental cost and availability.

Dispatching conventional equipment hourly on a lowest incremental cost basis against utility loads that have been modified by WECS 
Table :-1. Computer Programs for the Economic Analysis of WECS In a Utility Environment

\section{PROGRAM}

NAME

SERIES

WINDS

PHASFS

AVERAGE

CAP6

GENSYS

\section{FUNCTION}

To process mult1-year raw wind data and calculate expected annual wind power

To generate any missing wind speed data and to and to calculate cond1tional power probability distributions

To process sinģ le-year raw load data into format required by AVERAGE

To generate a singleyear's average load data from a history of single year load data

To calculate ut1lity Loss of Load Probability (LOLP)

To define the dispatching order of avallable conventional equipment

\section{INPUT}

Hourly wind data and WECS and array performance characteristics

Output of SERIES and WESC array performance characteristics

Hourly utility load data

Output of PHASES for more than one year

Load data from program AVERAGE, wind distributions from program WINDS and equipment operating parameters

Avallable conventional equipment and their econom 1c/operating parameters

\section{OUTPUT}

Average wind speed and power by phase and hour and Weibull distribution parameters $C$ and $k$ for both single WECS sites and a typical WECS site in an array

Average wind speed and power by phase and hour and Welbull distribution parameters C and $K$ for a typical WECS in a simulated WECS array. WINDS interpolates between spatial and chronological data points supplled by program SERIES to generate missing wind speed data and generates WESC conditional power probability distributions.

Load data by phase, load shape, and hour for a single year

Averaged load data by phase, load shape and hour for a single year.

Utility Loss of Load Probability (LOLP)

A rank ordering of avallable conventional equipment according to incremental cost and minimum run time 
Table C-1 (Continued)

\begin{tabular}{|c|c|c|c|}
\hline NAME & FUNCTION & INPUT & OUTPUT \\
\hline NETLOAD & $\begin{array}{l}\text { To project load } \\
\text { and define available wind } \\
\text { power in year of analysis }\end{array}$ & $\begin{array}{l}\text { Load shapes by phase } \\
\text { from AVERAGE, wind speed } \\
\text { distributions from WINDS, } \\
\text { and load scaling Information }\end{array}$ & $\begin{array}{l}\text { Utility load and expected wind power in the } \\
\text { year of analysis }\end{array}$ \\
\hline PROCOST & $\begin{array}{l}\text { To calculate the single } \\
\text { year variable utility } \\
\text { dispatching costs for } \\
\text { any WECS penetration } \\
\text { level }\end{array}$ & $\begin{array}{l}\text { Available conventional } \\
\text { equipment from GENSYS, } \\
\text { utility load and estimated } \\
\text { available wind power from } \\
\text { NETLOAD, (or estimated avail- } \\
\text { able wind power from WINDS) } \\
\text { and averaged utility loads } \\
\text { frum AVtiluili }\end{array}$ & $\begin{array}{l}\text { Variable production costs accrued by } \\
\text { conventional sources satisfying WECS } \\
\text { modified utility load }\end{array}$ \\
\hline EVEN & $\begin{array}{l}\text { To determine present } \\
\text { value of marginal wECS } \\
\text { unit and installation } \\
\text { values }\end{array}$ & $\begin{array}{l}\text { Fixed and Variable single } \\
\text { year available funds, land } \\
\text { and interface costs, and } \\
\text { utility economic paraneters }\end{array}$ & $\begin{array}{l}\text { WECS unit and installation values as a } \\
\text { function of WECS power level }\end{array}$ \\
\hline
\end{tabular}


available power, program PROCOST calculates the variable cost of satisfying utility load requirements. The difference between the annual cost of satisfying the modified load for a given wECS power level and the annual cost of satisfying the original utility load, is the single-year production funds made available (at that wECS power level) by the addition of WECS to the utility mix.

$$
\text { Program CAPG calculates the loss of load probability (LOLP) }
$$

associated with a specific utility equipment mix. Because the inclusion of WECS into a utility's equipment mix makes the utility more reliable, maintaining a specific LOLP with NECS as a part of the equipment mix can be done with fewer conventional sources. For a given weCs penetration, program CAPG is exercised with continuous reductions in installed peaking units until utility LOLP returns to its original value. This reduction in the required installed capacity of conventional sources translates into a reduction in utility capital costs, which is a cost savings that can be credited to weCs.

Program EVEN uses the total funds made available by WECS in a single year... and estimates the stream of yearly savings produced by the WECS over its lifetime. The sum of the stream of yearly savings discounted back to the year of analysis is the total life-cycle funds made available by WECS. Program EVEN performs this calculation for various wECS power levels and subsequently generates the function that relates WECS total life-cycle savings to WECS power level. The program differentiates this function at various points and creates a set of 
marginal values as a function of wECS power level; marginal values represent the total funds available for the purchase of the next WECS unit. By subtracting WECS related costs (including land and interface costs) from the total (marginal) available funds, program EVEN calculates the amount of funds that remain for the purchase of the next WECS unit (including transportation and erection) and installation. 
(

APPENDIX D

Other Computer Programs 
THIS PAGE

\section{WAS INTENTIONALLY \\ LEFT BLANK}


Several computer programs were developed during the course of the study to facilitate execution of the JBF programs and to process and display the wind and load data. The programs are described below. 1. JBFIN. This program allows the user to interactively create, edit, and display input parameter files for each of the programs in the JBF group of programs.

2. PHLOAD. Given the total utility load" at five time points $(0,6,12,18$ and 24 hours) for each of the four load types (A-Saturday, B-Sunday and holiday, C-peak weekday, D-average of other weekdays), program PHLOAD formulates a fourthorder Lagrangian polynomial fit to that data. Load values for hours 1 through 24 are then interpolated using the polynomial.

3. WNDPH. Program WNDPH was written to translate the monthly wind data files created by WNDEIL into phase-by-phase data files to be used by program SERIES.

4. PSIWMO. PSIWMO translates PSI weather data into monthly wind data files. Two wind data files are created for each month: one for wind measurements at 60 meters and the other for thoee at 10 meters.

5. Plotting Routines for Wind Data. All of the wind data extracted from the National Climatic Center (NCC) and Public 
Service Indiana (PSI) weather tapes was assembled into monthly files and stored on magnetic tape. A year's worth of monthly files may be easily converted into phase-by-phase files for input to program SERIES. A plotting routine is available for plotting both monthly and phase-by-phase data.

6. CORR. Given up to ten phase-by-phase data files (containing wind speed, utility load, or wind energy data), program CORR calculates the cross-correlation coefficient for the data in each distanct pair of files. By this means the correlation of wind speed anong several sites or the correlation of available wind power and utility load may be determined.

7. PLDSUM. Program PLDSUM performs a statistical summary of utility load data in monthly or phase-by-phase load files. It is analogous to program WNDSUM for wind data files.

8. IMPSUM. Program IMPSUM extracts monthly or phase-by-phase summary information from wind or load data files and displays this information in a table.

9. Load Data Plotting Package. Routines have been developed for plotting both monthly and phase-by-phase utility load data. 


\section{APPENDIX E}

Production Cost Simulations 


\section{THIS PAGE \\ WAS INTENTIONALLY \\ LEFT BLANK}

228 
Results of the utility production cost simulations for various penetrations of an array of Millville 100KW wind turbines are reproduced on the following pages. The array was assumed to operate in a wind regime like that of Indianapolis. Seven levels of on-line wECS capacity were assumed: $0,18,36,72,144,288$, and 432 IN. Yearly totals are for 1990. 
MILLUILLE 1OOKW WIKD TURBBINE AT, SITE IF (INDIANAFOLIS)

NUIABER OF WIMD MACHINES:: 0

WECS UNIT CAFACITY= $100.0 \mathrm{KW}$

YEAFLY TOTALS FOR 1790

NUMEER DF INITS USEII $\cdot .34$

\begin{tabular}{|c|c|c|c|c|c|}
\hline NIT & DI:ERAT ING & UISFATCHEI & $C F$ & IART & HEAT SFENT \\
\hline מא, & $\operatorname{cosT}(x)$ & ENEROY (MIHE) & $(\%)$ & (HR) & (MBTU) \\
\hline 1 & 130125. & 4032530 & 72.50 & 0 & 38816952 . \\
\hline$\frac{2}{3}$ & $\begin{array}{c}104224, \\
42791 .\end{array}$ & $\begin{array}{l}3222757, \\
1323153 .\end{array}$ & $\begin{array}{l}37,74 \\
23,79\end{array}$ & $\begin{array}{l}18 \\
18\end{array}$ & $\begin{array}{l}31019038, \\
12775381\end{array}$ \\
\hline 4 & 1.3370 . & 506187. & 9,10 & 18 & 1372070 \\
\hline $\begin{array}{l}5 \\
6\end{array}$ & $\begin{array}{l}80558 . \\
71823\end{array}$ & $\begin{array}{l}2915882 . \\
2704735 .\end{array}$ & $\begin{array}{l}70,82 \\
65,70\end{array}$ & $\begin{array}{l}24 \\
24\end{array}$ & $\begin{array}{l}28100688 . \\
26346064 .\end{array}$ \\
\hline$?$ & 20002 . & 512603. & 19.95 & 10 & 6309809 \\
\hline 8 & 17271. & 529967. & 13,13 & 10 & 5448360 \\
\hline 9 & 17324. & 530581. & 43.26 & 10 & 9464981. \\
\hline 10 & 14599. & 147101. & 36,16 & 10 & 1605139. \\
\hline $\begin{array}{l}11 \\
12\end{array}$ & $\begin{array}{l}4280 . \\
4073 .\end{array}$ & $\begin{array}{l}123514 . \\
117533 .\end{array}$ & $\begin{array}{l}16,59 \\
15,79\end{array}$ & $\begin{array}{l}10 \\
10\end{array}$ & $\begin{array}{l}1281459, \\
1219461,\end{array}$ \\
\hline 1.3 & 2758. & 79586. & 10,69 & 10 & 825710. \\
\hline 1.4 & 2279. & 65707. & 8.8.3 & 10 & 682328 . \\
\hline 3. 5 & 1978 & 56573 & $b: 80$ & 10 & 592321. \\
\hline 15 & 15911. & 462494. & 20.70 & 12 & 4763690 \\
\hline $\begin{array}{l}17 \\
19\end{array}$ & $\begin{array}{c}1766 \\
779 .\end{array}$ & $\begin{array}{l}34901 . \\
15398 .\end{array}$ & $\begin{array}{l}8.85 \\
3.91\end{array}$ & $\begin{array}{l}4 \\
4\end{array}$ & $\begin{array}{l}465925 . \\
205566 .\end{array}$ \\
\hline 17 & 2950. & 75963. & $19 \cdot 27$ & 5 & $\begin{array}{l}945745 . \\
830252 .\end{array}$ \\
\hline $\begin{array}{l}20 \\
21\end{array}$ & $\begin{array}{l}2599 . \\
2397:\end{array}$ & $\begin{array}{l}65887 . \\
53947 .\end{array}$ & $\begin{array}{r}16.92 \\
8.97\end{array}$ & $\begin{array}{l}5 \\
5\end{array}$ & $\begin{array}{l}830252, \\
733890 .\end{array}$ \\
\hline 22 & 600. & $157 ?=$ & $1 \cdot 12$ & 1 & 28639 , \\
\hline 23 & 376. & 1049 . & 0.70 & 1 & 17956 \\
\hline 24 & 299. & 334, & 0.56 & 1 & 14384. \\
\hline 25 & 220. & 61.4. & 0.11 & 1 & 10512. \\
\hline 26 & 137. & 381 . & 0,24 & 1 & 5522 \\
\hline 27 & 70. & $195:$ & 0.12 & 1 & 3350 \\
\hline 28 & 6422. & 21324. & 4.97 & 1 & 290606. \\
\hline 29 & 3388 . & 11251. & 2.62 & 1 & 153322 , \\
\hline 30 & 1175. & 4898: & 6.99 & 1 & 52462. \\
\hline 31 & 1754. & 7737. & 8.03 & 1 & 77907. \\
\hline 32 & 6926. & 185066. & 3.38 & 12 & 1832157. \\
\hline 33 & 97527. & 6233751 . & 69.97 & 0 & 65454380 \\
\hline 34 & $9818 ?:$ & 623.3751. & 69.97 & 0 & 65454380 \\
\hline
\end{tabular}

TOTAL OFERATING COST(K\$)

TOTAL OISFNTCHED ENERGY (GIUE)

TOTAL IUUNFEII ENERGY (MWE)

COST SAUINGS OF LAST HECS $(\$ / \mathrm{KW})$

ENERGY IIUMFEI BY DKE HORE WECS (NHE)

TDTAL NIMI ENEFGY FRODUCEO(MWE)

\footnotetext{
777243.562

30684.984

0.000

$1.27,893$

0.000

0.000
}

UHITS OF FUEL FUEL CONSUMER TYFE

1802924. TONS COAL

1410736. TOHS COAL

591517. TOKS COAL

22.5292, TDMS ROAL

1265418, TOKS COAL

1266.38. TOMS COAL

286810. TONS COAL

217653. TOHS COAL

248408, TONS COAL

209325. TONS COAL

59327. TONS COAL

56157, TONS CDAL

38227, TOHS COAL

31389 . TONS COAL

27422. TDNS COAL

220541. TONS CDAL

21471: TOKS COAL

9173 , TOMS COAL

43583. TONS COAL

38260, TONS COAL

33820. TOHS COAL

209043, GAL OIL

131059. GAL OIL

1042.50. GAL OIL

76731, GAL OIL

17605. GAL OIL

24156. GAL OIL

2121212. GAL OIL

1119140 . GAL OIL

392939 . GAL OIL

568663 . GAL OIL

85098. TONS COAL

259740, MWIIA KUCL

259740. MWOA MULLL

8350988. TONS COAL

1785112. GAL OIL

519179 . KGWDA KUCL 
MILLUILLE 1OOKIN WIHD TURBINE AT SITE IP (INDIAHAFOLIS)

NUMEER OF ISIMU MACHIMES:: 190

WEES UNIT CAFACITY:= $100,0 \mathrm{KWW}$

YEARLY TOTALS FOR 1790

NIJHER QF UNITS USED $\quad \cdot 34$

\begin{tabular}{|c|c|c|c|c|}
\hline $\begin{array}{l}\text { UNIT } \\
\text { ND. }\end{array}$ & 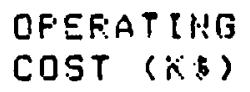 & $\begin{array}{l}\text { IISFATCHED } \\
\text { ENEFGY (MINE) }\end{array}$ & $\begin{array}{l}C F \\
(\%)\end{array}$ & $\begin{array}{l}\text { IART } \\
\text { (HR) }\end{array}$ \\
\hline 1 & 130125 . & 1032930. & 72.50 & 0 \\
\hline 2 & $10+103$ & 3219028, & 57.87 & 18 \\
\hline 3 & $1 \geq 701$. & 1320392. & 23,74 & 18 \\
\hline 4 & 16341. & $505279=$ & 9.08 & 18 \\
\hline 5 & 80553 & $2915<85$. & 70.82 & 24 \\
\hline$\dot{0}$ & 74783. & 2703.591 , & 65.67 & 21 \\
\hline 7 & 19961. & 611356. & 19.85 & 10 \\
\hline 9 & 17212. & 527119, & 12.99 & 10 \\
\hline$?$ & 17257. & 528827 . & 43.12 & 10 \\
\hline 10 & 14510. & 144401. & 36.34 & 10 \\
\hline 11 & 4267. & 123117. & 16.54 & 10 \\
\hline 12 & 1037. & 116371 , & 15.56 & 10 \\
\hline 1.3 & 27.1. & 79196. & 10.61 & 10 \\
\hline 1. 4 & 2270 & 5.5500, & 8.80 & 10 \\
\hline 15 & $! 971$. & 56438. & 6.78 & 10 \\
\hline 1.5 & 1.5797. & 459176. & 20.56 & 12 \\
\hline $\begin{array}{l}17 \\
18\end{array}$ & $\begin{array}{r}1708, \\
718 .\end{array}$ & $\begin{array}{l}3.3751 . \\
14793 .\end{array}$ & $\begin{array}{l}8.56 \\
3.75\end{array}$ & 4 \\
\hline 19 & 2906. & 74564. & 18.92 & 5 \\
\hline 20 & 2510. & 65183. & 16.54 & 5 \\
\hline 21 & 2200. & 56459. & 8.59 & 5 \\
\hline 22 & 497. & 13.57 & 0.71 & 1 \\
\hline 23 & 334. & 930. & 0.62 & 1 \\
\hline 24 & 231. & 794. & 0.53 & 1 \\
\hline 3 & 200. & $557:$ & 0,37 & 1 \\
\hline 26 & 110. & 307 . & 0.17 & 1 \\
\hline 27 & 70. & 195. & 0.12 & 1 \\
\hline 23 & 5979. & 19853. & 4,53 & 1 \\
\hline 39 & 3055 . & 10113. & 2.36 & 1 \\
\hline 30 & 1112. & 1630 & 6.61 & 1 \\
\hline 31 & 1617. & 7133. & 7.40 & 1 \\
\hline 32 & 5835 , & 183970. & 3.36 & 12 \\
\hline 33 & 97527 & 6233751 . & 69.97 & 8 \\
\hline$A$ & 9818 & 423375 & 69 & 0 \\
\hline
\end{tabular}

HEAT SPEKT (MBTU)

38816952 .

30983131 .

12709772 .

1953298 ,

23378772 .

26333911 .

6.995963.

5429.536.

5416917 .

4577332 .

1277651.

1209425.

$821651:$

6795.56.

590901.

4729512 .

450572 .

197353.

923323.

911523 ,

702920 .

23232 .

15934 .

13420 .

9546 .

5251 .

3335 .

270556 .

138234 .

49611.

71823 .

1821293 ,

65454380 。

65454380 .
UHITS OF FUEL FUEL CONSUMED TYPE

1802924. TOHS COAL 1439068. TONS COAL 570282, TOHS COAL 225895. TONS COAL 1365326. TONS COAL 126.5055 . TONS COAL 286226 . TONS COAL 245802. TOMS CDAL 247587. TOMS COAL 208061. TOMS CDAL 59151. TONS COAL 53992. TOMS COAL 38040. TONS COAL 31161 . TOHS CDAL 27357. TOHS COAL 218959. TOMS COAL 20764. TOHS COAL 9095 . TONS COAL 12780. TONS COAL 37397 . TOYS COAL 32393. TONS COAL 169579. GAL OIL 116308 , GAL OIL 97951 . GAL OIL 69380 . GAL OIL 39329. GAL OIL 2A3:0. GAL OIL 1974860. GAL DIL 1009009 . GAL OIL 362364 . GAL OIL 524256. GAL OIL 81394. TOMS CDAL 259740. IIWIIA NUCL 259710. MWOA HUCL

8336195. TONS COAL 4386679, GAL OIL 519179, HWLIA NUCL
TQTAL OFEFIATING COST(K\$)

TOTAI. IISFATCHED EMERGY (GHE)

TOTAL DUMFED EWERGY (KWE)

COST SAUINGS DF LASTT WEC.S (\$/KW)

ENEFIGY IUUAFED EY ONE MORE WECS (MWE)

TOTAL. WINT ENERIGY FRODUCEO (MWE)
774992.625

$306 ! 50.869$

0.000

122,639

0.000

34171,797 
MILLUILLE $100 K W$ WINI TURBINE AT SITE IF (INIIANAFOLIS)

\author{
NUMAER DF WIND NACHINES:: 360 \\ WECS UMIT CAPACITY= 100.0 FW
}

YEARLY TOTALS FOR 1790

RUUMEER OF LINITS USED $\cdots$.. 34

\begin{tabular}{|c|c|c|c|c|c|}
\hline VIT & OFERATING & DISF'ATCHEII & CF & IFRT & HEAT \\
\hline No. & COST (K⿺) & ENERGY (MUE) & $(\%)$ & $(H F)$ & (MBTU) \\
\hline 1 & 130425 & 1032930 & 72.50 & 0 & $3881695:$ \\
\hline ? & 103982, & 3219271 & 57.80 & 19 & 3094.59 \\
\hline 3 & 42511. & 1317604. & 23.67 & 18 & 1268193 \\
\hline 4 & 16312 & 504392. & 9.07 & 18 & $18947 ?$ \\
\hline 5 & 80647 . & 2915486 & 70.81 & 24 & 2829687 \\
\hline 6 & 74754 & 2702145, & 85.64 & 24 & 25.32 \\
\hline 7 & 19913. & 609832. & 49.73 & 10) & 628178 \\
\hline 8 & 17156. & 525439 & 32.84 & 10 & $5+1201$ \\
\hline 9 & 17212. & $527152 。$ & 12.98 & 10 & 5.12966 \\
\hline 10 & 14115. & 411478 & $30 . n$ & 10 & 49423 \\
\hline 11 & 4255 & 122782. & $16: 49$ & 10 & 12738 \\
\hline 12 & 4006. & 115598. & 1.5 .52 & 10 & 11993 \\
\hline 1.3 & 2729. & 79765. & 10.58 & 10 & 81718 \\
\hline 14 & 22.51. & 59334 & 3.7 .5 & 10) & 57.58 \\
\hline 15 & 19.53. & 55278. & 5.76 & 10 & 589 \\
\hline 16 & 15687. & 455994. & 20.11 & 12 & 1.59673 \\
\hline 17 & 1649. & 32599. & 8.27 & 4 & 13519 \\
\hline 18 & 715. & 14129. & 3.58 & 4 & 1989 \\
\hline 19 & 2854 & 73231. & $1 B .58$ & 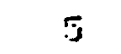 & 91172 \\
\hline 20 & 2474. & 03476. & 16.10 & 5 & 79027 \\
\hline 21 & 2106. & 54051 . & 8.23 & 5 & 57293 \\
\hline 22 & 124. & 1183. & 0.79 & 1 & 2025 \\
\hline 2.3 & 320. & 892. & 0.50 & 1 & 1527 \\
\hline 24 & 232. & 701. & 0.47 & 1 & \\
\hline 25 & 183. & 509. & 0.34 & 1 & 872 \\
\hline 26 & 92. & 256. & 0.1 .5 & 1 & \\
\hline 27 & 70 & 195. & 0.12 & 1 & 333 \\
\hline 28 & 5545. & 18414 & 4.29 & 1 & 25005 \\
\hline 29 & 2689 . & 8927. & 2.08 & 1 & 1216 : \\
\hline 30 & 1067. & 4450. & 5.35 & 1 & 4765 \\
\hline 31 & 1509 & 6656. & 6.91 & 1 & 6701 \\
\hline 32 & $\$ 813$. & 182819 , & 3.34 & 12 & 191020 \\
\hline 33 & 97527 & 6233751. & 69.97 & 0 & 654543 \\
\hline 34 & 73182, & 623.3751 & 69,97 & 0 & 6545 \\
\hline
\end{tabular}

TOTAL OFEFIATING COST(K\$)

TOTAL DISFNTCHED ENERGY (GWE)

TOTAL CIIUMFEII EMERGY (IMWE)

COST SAUINGS OF LAST HECS $\$ / K W)$

ENERTY IUUMFEII BY ONE MORE WECS(MUE)

TOTAL WIND ENERGY FRONUCEIIMUE)

\author{
772833.375 \\ 30615,740 \\ 0.000 \\ 117.999 \\ 0.000
}

63343.394
UNITS OF FUEL FUEL CONSUMED TYPE

1802921, TONS COAL

1437389. TOHS COOAL

589036, TONS COAL

239499. TOMS COAL

1365232. TONS COAL

1265473. TONS COAL

285536. TONS COAL

215001. TONS COAL

246803, TONS COAL

206692. TOHS COAL

58975. TONS COALL

35525. TONS COAL

37833. TONS COAL

31333 , TONS COAL

27279, TOMS COAL

217111. TOMS COAL

20055. TONS COAL

3590. TONS CDAL

12015. TONS COAL

36413, TONS CDAL

Z1011, TONS COAL

117916, GAL QIL

111178 , GAL OIL

37599, GAL OIL

63570, GAL OIL

32054. GAL OIL

21310, GAL OIL

1831767. GAL OIL

887979, GAL OIL

317874 . GAL OIL

189178. GAL OIL

81078 . TONS COAL

259740. HWLA NUCL

259740. HWIIA MUCL

8321227. TONS COAL 1023756, GAL OIL

519479 . IYWIIA KUCL 
MILLUILLE 10OKW WIMD TUREIME AT SITE IF (INDIANAPOLIS)

NUMBER OF IIMD MACHINES:: 720

WECS UNIT CAFACITY:= $100.0 \mathrm{KW}$

YEAFLY TDTALS FOR 1790

NUMBER OF UNITS USEI -. 34

\begin{tabular}{|c|c|c|c|c|c|c|c|c|}
\hline $\begin{array}{l}\text { UNIT } \\
\text { ND. }\end{array}$ & $\begin{array}{l}\text { OFEEFATING } \\
\text { COST (KN\$) }\end{array}$ & $\begin{array}{l}\text { IISFATCHED } \\
\text { ENERTY ( IINE) }\end{array}$ & $\begin{array}{l}C F \\
(\%)\end{array}$ & $\begin{array}{l}\text { NRT } \\
\text { (HR) }\end{array}$ & $\begin{array}{l}\text { HEAT SPENT } \\
\text { (MBTU) }\end{array}$ & $\begin{array}{l}\text { UHITS OF } \\
\text { CONSUME }\end{array}$ & $\begin{array}{l}\text { FUEL } \\
\text { :0 }\end{array}$ & $\begin{array}{l}\text { FUEL } \\
\text { TYFE }\end{array}$ \\
\hline 1 & 130425 . & 1032930. & 72.50 & 0 & 28816952 , & 1802924. & TONS & COAL \\
\hline$\frac{2}{3}$ & $\begin{array}{r}10373 \pi \\
12433\end{array}$ & $\begin{array}{l}3207528, \\
1312083 .\end{array}$ & $\begin{array}{l}57.56 \\
23.59\end{array}$ & $\begin{array}{l}19 \\
18\end{array}$ & $\begin{array}{l}30873419, \\
12528799 .\end{array}$ & $\begin{array}{r}1433972 . \\
386568 .\end{array}$ & $\begin{array}{l}\text { TDNS } \\
\text { TONS }\end{array}$ & $\begin{array}{l}\text { COAL } \\
\text { COAL }\end{array}$ \\
\hline 4 & 1.6252. & 502523. & 9.03 & 13 & 1836935 & 221650. & TONS & COAL \\
\hline $\begin{array}{l}5 \\
6\end{array}$ & $\begin{array}{l}80635 \\
74683\end{array}$ & $\begin{array}{l}2915055 . \\
2699831,\end{array}$ & $\begin{array}{l}70.80 \\
55.58\end{array}$ & $\begin{array}{l}24 \\
24\end{array}$ & $\begin{array}{l}28392636 . \\
26296810 .\end{array}$ & $\begin{array}{l}1255031 . \\
1264271 .\end{array}$ & $\begin{array}{l}\text { TOHS } \\
\text { TONS }\end{array}$ & $\begin{array}{l}C O A \\
C O A\end{array}$ \\
\hline 7 & 19817. & 606917 . & 19.19 & 10 & 6251553. & 284161 & TONS & COA \\
\hline 8 & 17041. & 521713. & 42.56 & 10 & 5375705. & 244350 . & TONS & $D A$ \\
\hline 7 & 17107. & 523931. & 42.72 & 10 & 3376319. & 245296. & & \\
\hline 10 & 14218 & 435452 . & 35.51 & 10 & 1485156 . & 203971 . & TOMS & co \\
\hline 11 & 4223. & 121875 . & 16.37 & 10 & 1264450. & 58537. & TO & \\
\hline 12 & 3942. & 113765, & 15.28 & 10 & 1180315 & 54644. & & \\
\hline .13 & 2701. & 77950. & 10.47 & 10 & 808735. & 37441. & TONS & $\operatorname{COA}$ \\
\hline 14 & 2212 & .41713. & 8.69 & 10 & 571397. & 31083 & TDNS & \\
\hline 15 & $195 \%$ & 55703. & 6.72 & 10 & 585307. & 27098. & TONS & $\mathrm{CO}$ \\
\hline 16 & 15467. & 149602 & 20.13 & 12 & 1630899. & 214393. & TONS & $\operatorname{COA}$ \\
\hline 17 & 1536 . & 30.355 . & 7.70 & 4 & 105240. & 18675. & TONS & $\mathrm{COA}$ \\
\hline 18 & 637. & 12582 . & 3.19 & 4 & 167970. & 7741 & TONS & $\mathrm{COA}$ \\
\hline 1.9 & 2737 & 70237. & 17.82 & 5 & 874119. & 10257. & TONS & COA \\
\hline 20 & 2338. & 50009. & 15,22 & 5 & 747109. & 31429. & TONS & $\mathrm{COA}$ \\
\hline 21 & 1930 & 47519. & 7.54 & 5 & 616507 . & 28410 . & TONS & COA \\
\hline 22 & 340. & 746. & 0.64 & 1 & 16198. & 113236. & GAL & DIL \\
\hline $\begin{array}{l}23 \\
24\end{array}$ & $\begin{array}{l}289 \\
215\end{array}$ & $\begin{array}{l}804 \\
598\end{array}$ & $\begin{array}{l}0.51 \\
0.40\end{array}$ & $\begin{array}{l}1 \\
1\end{array}$ & $\begin{array}{l}13770 . \\
10238 .\end{array}$ & $\begin{array}{l}100511 . \\
74729\end{array}$ & $\begin{array}{l}\text { GAL } \\
\text { GAL }\end{array}$ & $\begin{array}{l}\text { OIL } \\
\text { OIL }\end{array}$ \\
\hline 25 & 133. & 371 . & 0.25 & 1 & 6316. & 46322 & GAL & DIL \\
\hline 26 & 79 & 221. & 0,11 & 1 & 3776. & 27563. & GAL & DIL \\
\hline 27 & 70. & 195. & 0.12 & 1 & $3.335:$ & 24340 , & GAL & OIL \\
\hline 23 & 4796. & 15926, & 3.71 & 1 & 217035. & 1584197. & GAL & OIL \\
\hline $\begin{array}{l}29 \\
30\end{array}$ & $\begin{array}{r}1982 . \\
913 .\end{array}$ & $\begin{array}{l}6580 . \\
3908\end{array}$ & $\begin{array}{l}1.53 \\
5.13\end{array}$ & $\begin{array}{l}1 \\
1\end{array}$ & $\begin{array}{l}89678 \\
10789\end{array}$ & $\begin{array}{l}651582 . \\
297724 .\end{array}$ & GAL & OIL \\
\hline 31 & 1378 & 6077. & 6.31 & 1 & 61187. & 146619. & GAL & OIL \\
\hline 32 & 6759. & 061 & 3.30 & 12 & 1739079. & 83051. & TOMS & $\mathrm{COA}$ \\
\hline 33 & 97537. & 4233751 . & 69.97 & 0 & 65451380. & 259710. & NWDA & NUS \\
\hline 34 & 93182. & 6233751 . & 69.97 & 0 & 65451380. & 259710. & IFWDA & 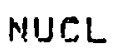 \\
\hline
\end{tabular}

TOTAL OFERATING COST(KK)

TOTAL. DISFOTCHED ENERG\% (GWE)

TOTAL IUUNFEII ENERGY (MWE)

COST SAUINGS DF LAST WECS ( $\$ / K W$ )

ENEREY IIUMFEII EY ONE MORE WECS(MUE)

TDTAL WIND ENERISY FRONUCED (IGINE)

$$
\begin{array}{r}
768716.312 \\
30548.496 \\
0.000 \\
111.319 \\
0.000
\end{array}
$$

$13.5687,197$
3290902. TOKS COAL 3.374824 . GAL OIL 519479, I4UIIA KUCL 
MILLUILLE 10OKW WIND TUFBINE AT SITE IP (INDIANAFOL.IS)

NUMEEF DF UIMD MACHINES= 1410

WECE UNIT CAPACITY $=100.0 \mathrm{kWW}$

YEAFLY TOTALS FOR 1990

NUMEER OF INNITS USEI - 34

\begin{tabular}{|c|c|c|c|c|c|}
\hline $\begin{array}{l}\text { JNIT } \\
\text { ND. }\end{array}$ & $\begin{array}{l}\text { OFERATING } \\
\text { DOST (K\$) }\end{array}$ & $\begin{array}{l}\text { IIISFATCHED } \\
\text { ENERSY (IGWE) }\end{array}$ & $\begin{array}{l}C F \\
(\%)\end{array}$ & $\begin{array}{l}\text { HART } \\
(H R)\end{array}$ & $\begin{array}{l}\text { HEAT SPENT } \\
\text { (MBTU) }\end{array}$ \\
\hline 1 & 130425 . & 1032930 & 72.50 & 0 & 28816952 \\
\hline$\frac{2}{3}$ & $\begin{array}{r}103215, \\
42075 .\end{array}$ & $\begin{array}{l}3171561 . \\
1301052 .\end{array}$ & $\begin{array}{l}57.39 \\
23.39\end{array}$ & $\begin{array}{l}18 \\
18\end{array}$ & $\begin{array}{l}30718770 \\
12522621\end{array}$ \\
\hline 4 & 1.5131 . & $498782 \ldots$ & 9.97 & 18 & 1800779 \\
\hline 5 & $\begin{array}{l}80611 . \\
74533 .\end{array}$ & $\begin{array}{l}2914181 . \\
2694447 .\end{array}$ & $\begin{array}{l}70.78 \\
6.9 .14\end{array}$ & $\begin{array}{l}24 \\
24\end{array}$ & $\begin{array}{l}28384124 \\
26243910\end{array}$ \\
\hline 7 & 19625. & 601061. & 49.01 & 10 & 6190955 \\
\hline $\begin{array}{l}8 \\
9\end{array}$ & $\begin{array}{l}16310 . \\
16861 .\end{array}$ & $\begin{array}{l}514851 . \\
516407 .\end{array}$ & $\begin{array}{l}11.98 \\
12.11\end{array}$ & $\begin{array}{l}10 \\
10\end{array}$ & $\begin{array}{l}5302970 \\
5318990\end{array}$ \\
\hline 10 & 1.3827 & 423492. & 34.53 & 10 & 4361966 \\
\hline $\begin{array}{l}11 \\
1 ?\end{array}$ & $\begin{array}{l}4138 . \\
3809 .\end{array}$ & $\begin{array}{l}117120 . \\
109989 .\end{array}$ & $\begin{array}{l}16.04 \\
14.75\end{array}$ & $\begin{array}{l}10 \\
10\end{array}$ & $\begin{array}{l}1238979 \\
1140084\end{array}$ \\
\hline$i 3$ & 2553. & 76565. & 10.28 & 10 & 794362 \\
\hline $\begin{array}{l}17 \\
15\end{array}$ & $\begin{array}{l}2203 . \\
1934 .\end{array}$ & $\begin{array}{l}53580 . \\
55300 .\end{array}$ & $\begin{array}{l}8.51 \\
6.55\end{array}$ & $\begin{array}{l}10 \\
10\end{array}$ & $\begin{array}{l}559641 \\
578988\end{array}$ \\
\hline is & 1.5024. & 4.36727 . & 19.55 & 12 & $449: 728$ \\
\hline 17 & 1273 & 25164. & 6.38 & 4 & 33 \\
\hline 18 & 526. & 10397. & 2.54 & 4 & \\
\hline 19 & 2475 . & 63526. & 16.12 & 5 & 79089 \\
\hline 20 & 2019. & 52594 & 13.31 & 5 & 651 \\
\hline 21 & 1648. & +2281 . & 6.14 & 5 & 526.39 \\
\hline 22 & 273. & 761 , & 0.51 & 1 & 1302 \\
\hline 23 & 198. & 551. & 0.37 & 1 & 94 \\
\hline 24 & 152 & & $? 8$ & 1 & \\
\hline 25 & 3.3. & 230. & 0.15 & 1 & 394 \\
\hline 2.5 & 70. & 195. & 0.12 & 1 & 3.3 \\
\hline 27 & 60. & 168. & 0.11 & 1 & 2883 \\
\hline 28 & 33.94. & 11231 , & 2.62 & 1 & 153103 \\
\hline 29 & 1100 . & 3651. & 0.85 & 1 & 4975 \\
\hline 30 & & 2726. & 3.89 & 1 & 27194 \\
\hline 31 & 953. & 4205. & 4.35 & 1 & 42336 \\
\hline 32 & 6591. & 176136. & 3.22 & 12 & 1743750 \\
\hline 3.3 & & 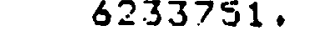 & 69.97 & 0 & (2) \\
\hline 34 & 98182, & 523.3751 , & 69.97 & 0 & 65454380 \\
\hline
\end{tabular}

TOTAL OFERATING COST ( $K \$)$

TOTAL IIISPATCHEI ENERSY (GWE)

TOTAL DUMFEE ENERGY (MUE)

COST SAYINGS DF LAST HECS(\$,NW)

ENEREY IUUMFED BY ONE MORE NECS (MINE)

761072.687
30411.980
0.000
77.212
0.000
273374.375
UNITS OF FUEL FUEL COMSUMED TYFE 1802924. TONS COAL 1426799. TOMS COAL 381636. TONS COAL 222981. TOHS COAL 1364621. TONS COAL 1261727. TOMS CDAL 281407, TOHS COAL 241044. TOMS COAL 241772, TONS COAL 198271. TOMS COAL 37360, TONS COAL 32782, TOMS COAL 36776. TONS COAL 30539. TOHS COAL 26805. TONS COAL 208254. TOMS COAL 15481. TONS CDAL 6376. TOMS CDAL 36417. TONS COAL 30175. TONS COAL 24258. TONS COAL 9J105. GAL DIL 68833. GAL OIL 52813 . GAL DIL 28797. GAL OIL 24340. GAL OIL 21011. GAL OIL 1117335 . GAL OIL उद3153, GAL OIL 213091. GAL OIL 309022 . GAL OIL 90992. TONS COAL 259710. HWDA NUCL 259740. MWDA MUCL

8229436. TONS COAL 2293763. GAL OIL 519479\%, HWDA NUCL 
MILLUILLE 10OKW WIND TURBIHE AT SITE IP (IHDIANAFOLIS)

NUMBER OF GIMD NACHINES: 2880

WECS UNIT CAFACITY:: $i 00.0 \mathrm{KW}$

YEARLY TOTALS FOR 1990

NUMBER OF UNITS USED $\quad . \cdot 34$

\begin{tabular}{|c|c|c|c|c|c|}
\hline $\begin{array}{l}\text { UNIT } \\
\text { ND. }\end{array}$ & $\begin{array}{l}\text { OPERAT ING } \\
\text { COST (K\$) }\end{array}$ & $\begin{array}{l}\text { OISFATCHED } \\
\text { ENERGY (WWE) }\end{array}$ & $\begin{array}{l}C F \\
(\%)\end{array}$ & $\begin{array}{l}\text { MRT } \\
(H R)\end{array}$ & $\begin{array}{l}\text { HEAT SFENT } \\
\text { (MBTU) }\end{array}$ \\
\hline 1 & 130425 . & 4032930 . & 72.50 & 0 & 38816952 \\
\hline$\frac{2}{3}$ & $\begin{array}{r}102133 \\
41310\end{array}$ & $\begin{array}{l}3158115 \\
1277375\end{array}$ & $\begin{array}{l}56.77 \\
22.96\end{array}$ & $\begin{array}{l}18 \\
18\end{array}$ & $\begin{array}{l}30396852 . \\
12294734 .\end{array}$ \\
\hline 4 & 15871. & 190761. & 3.92 & 19 & 1723.57 \\
\hline $\begin{array}{l}5 \\
6\end{array}$ & $\begin{array}{l}80556 \\
74176\end{array}$ & $\begin{array}{l}2912204 . \\
2682272 .\end{array}$ & $\begin{array}{l}70.73 \\
.55 .15\end{array}$ & $\begin{array}{l}24 \\
24\end{array}$ & $\begin{array}{l}28364866 \\
26125321\end{array}$ \\
\hline 7 & 19206. & 588211 & 47.96 & 10 & 6058570 \\
\hline 3 & 16379. & 501640. & 40.70 & 10 & 516689 \\
\hline 9 & 16177. & 495450 . & 40.40 & 10 & 510313 \\
\hline 10 & 12771 . & 397267 . & 32.39 & 10 & 1091846 \\
\hline $\begin{array}{l}11 \\
12\end{array}$ & $\begin{array}{l}3914 . \\
3564 .\end{array}$ & $\begin{array}{l}112964 . \\
102840 .\end{array}$ & $\begin{array}{l}15.17 \\
13,81\end{array}$ & $\begin{array}{l}10 \\
10\end{array}$ & $\begin{array}{l}1171997 \\
106696\end{array}$ \\
\hline 1.3 & 2542 & 73355 & 9.85 & 10 & 76105 \\
\hline $\begin{array}{l}14 \\
15\end{array}$ & $\begin{array}{l}2123 . \\
1891 .\end{array}$ & $\begin{array}{l}61256 . \\
54086 .\end{array}$ & $\begin{array}{l}8.23 \\
6.50\end{array}$ & $\begin{array}{l}10 \\
10\end{array}$ & $\begin{array}{l}63553 \\
56627\end{array}$ \\
\hline 16 & 14215. & 113215 & 18.50 & 12 & 425611 \\
\hline 17 & 762. & 15058. & 3.82 & 4 & 20101 \\
\hline 13 & 321. & 6341 & 1.61 & 4 & \\
\hline 19 & 1946. & 49929. & 12.67 & 5 & 62163 \\
\hline 20 & 1545. & 39.541. & 10.06 & 5 & $4935=$ \\
\hline 21 & 1119. & 28727 . & 4.37 & 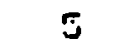 & 7.77 \\
\hline 22 & 146. & 408 . & 0.27 & 1 & $69:$ \\
\hline 23 & 136. & 380. & 0.26 & 1 & \\
\hline 24 & 72. & 201. & 0.13 & 1 & \\
\hline 25. & 63. & 175. & 0.12 & 1 & 299 \\
\hline 26 & 25. & 69. & 0.04 & 1 & \\
\hline 27 & 22. & 60. & 0.04 & 1 & \\
\hline 28 & 1282. & 4258 & 0.97 & 1 & 580 \\
\hline 29 & 583 & 1935. & 0.45 & 1 & \\
\hline 30 & 327 & 1365. & 1.75 & 1 & \\
\hline 31 & 484. & 2133. & 2.21 & 1 & 21 \\
\hline 32 & 6236 & (1) & 3.04 & 12 & \\
\hline 33 & & 62 & 97 & 0 & $7 \pi$ \\
\hline 34 & 9818 & 62337 & 97 & 0 & \\
\hline
\end{tabular}

UNITS OF FUEL FUEL CONSUMED TYFE

1802921. TONS COAL 1411837. TONS COAL 571051 . TONS COAL 219395. TONS COAL 1363696 . TONS COAL 1256025 . TONS COAL 275390. TONS COAL 234859. TOMS COAL 231961, TONS COAL 185993. TOMS COAL 51259. TONS COAL 19396. TONS COAL 35234 , TONS COAL 29123. TONS COAL 26217. TONS COAL 197012. TOHS COAL 9264. TOMS COAL 3901 . TOMS COAL 28616. TONS COAL 22743. TOMS COAL. 16482. TONS COAL 50963 . GAL OIL 17501. GAL OIL 25129. GAL OIL 21852، GAL OIL 3590. GAL OIL 7489. GAL OIL 423360. GAL OIL 192477. GAL OIL 1067A7. GAL OIL 15671A, GAL OIL 75623. TONS COAL 259740, HWDA NUCL 259710. MWDA MUCL

TOTAL OFERATIMG COST(K\$)

TOTAL DISPATCHED ENERGY (GWE)

TOTAL DUMFEII ENERGY (MWE)

COST SAUINGS OF LAST HECS $(\$ / \mathrm{KW})$

ENERGY OUMFEII BY OME MORE WECS (NUE)

TOTAL HIND ENERGY FROIUCED(IWE)

$$
\begin{array}{r}
71825 \hat{1} .687 \\
301.38 .766 \\
0.000 \\
90.514 \\
0.000
\end{array}
$$

546748.750
8102365. TONS COAL 1041042. GAL OIL 519179 . HWDA HUCL 
NUIGBER OF WIMD MACHINES: 4320

WECS UNIT CAFACITY:= $100.0 \mathrm{KWW}$

YEARLY TOTALS FOR 1990

NUMBEF OF UNITS USEII - 34

\begin{tabular}{|c|c|c|c|c|c|c|c|c|}
\hline $\begin{array}{l}\text { JNIT } \\
\text { NO. }\end{array}$ & $\begin{array}{l}\text { QFERAT ING } \\
\text { COST (K\$) }\end{array}$ & $\begin{array}{l}\text { IIISFATCHED } \\
\text { ENERGY (YWE) }\end{array}$ & $\begin{array}{l}C F \\
(\%)\end{array}$ & $\begin{array}{l}\text { MRT } \\
(H R)\end{array}$ & $\begin{array}{l}\text { HEAT SFENT } \\
\text { (NBTU) }\end{array}$ & $\begin{array}{l}\text { UNITS OF } \\
\text { CONSUM }\end{array}$ & FUEL & $\begin{array}{l}\text { FUEL } \\
\text { TYPE }\end{array}$ \\
\hline 1 & 130425. & 4032930. & 72.50 & 0 & 38816952 . & 1802924. & TONS & COAL \\
\hline$\frac{2}{3}$ & $\begin{array}{c}100991 \\
40510 .\end{array}$ & $\begin{array}{l}3122789 . \\
1252619 .\end{array}$ & $\begin{array}{l}56.14 \\
22.52\end{array}$ & $\begin{array}{l}18 \\
18\end{array}$ & $\begin{array}{l}30055840, \\
12056461 .\end{array}$ & $\begin{array}{r}1395045 . \\
559984 .\end{array}$ & $\begin{array}{l}\text { TOMS } \\
\text { TONS }\end{array}$ & $\begin{array}{l}\text { OAL } \\
\text { OAL }\end{array}$ \\
\hline 4 & 15539. & 182008 & 8.67 & 18 & 1639327. & 215192. & TOMS & 90 \\
\hline $\begin{array}{l}5 \\
6\end{array}$ & $\begin{array}{l}80493 . \\
73822 .\end{array}$ & $\begin{array}{l}2909916 . \\
2668751\end{array}$ & $\begin{array}{l}70.68 \\
64.82\end{array}$ & $\begin{array}{l}24 \\
24\end{array}$ & $\begin{array}{l}28342584, \\
25993656,\end{array}$ & $\begin{array}{l}1362621 . \\
1219696 .\end{array}$ & $\begin{array}{l}\text { TONS } \\
\text { TONS }\end{array}$ & COA \\
\hline 7 & 18694. & 572525. & 16.68 & 10 & 5897004. & 268046. & TONS & $\mathrm{COA}$ \\
\hline $\begin{array}{l}8 \\
9\end{array}$ & $\begin{array}{l}15831 . \\
15368 .\end{array}$ & $\begin{array}{l}196374 . \\
470663 .\end{array}$ & $\begin{array}{l}37.66 \\
28.38\end{array}$ & $\begin{array}{l}10 \\
10\end{array}$ & $\begin{array}{l}5009652 . \\
1847825 .\end{array}$ & $\begin{array}{l}227711 . \\
220356 .\end{array}$ & $\begin{array}{l}\text { TOYS } \\
\text { TOKS }\end{array}$ & $\mathrm{COA}$ \\
\hline 10 & 12167. & 372653 & 30.39 & 10 & 3838.323. & 174169. & TDis & $C O A$ \\
\hline $\begin{array}{l}11 \\
12\end{array}$ & $\begin{array}{l}3665 . \\
3300 .\end{array}$ & $\begin{array}{r}105765 . \\
75230 .\end{array}$ & $\begin{array}{l}11.20 \\
12.79\end{array}$ & $\begin{array}{l}10 \\
10\end{array}$ & $\begin{array}{r}1097312 . \\
988013 .\end{array}$ & $\begin{array}{l}50801 . \\
45711 .\end{array}$ & $\begin{array}{l}\text { TONS } \\
\text { TOMS }\end{array}$ & \\
\hline 13 & 2407. & 69459 . & 9.33 & 10 & 720637. & 33363. & TOMS & $\mathrm{COA}$ \\
\hline $\begin{array}{l}14 \\
15\end{array}$ & $\begin{array}{l}2049 . \\
1853 .\end{array}$ & $\begin{array}{l}59133 . \\
53000\end{array}$ & $\begin{array}{l}7.94 \\
6.37\end{array}$ & $\begin{array}{l}10 \\
10\end{array}$ & $\begin{array}{l}51.3505 . \\
554908 .\end{array}$ & $\begin{array}{l}28103 . \\
25690 .\end{array}$ & $\begin{array}{l}\text { TONS } \\
\text { TONS }\end{array}$ & \\
\hline 1.5 & 13357 . & 388275. & $17 \cdot 33$ & 12 & 3999235. & 135150. & TONS & CDA \\
\hline $\begin{array}{l}17 \\
18\end{array}$ & $\begin{array}{l}423 . \\
132 .\end{array}$ & $\begin{array}{l}8351 . \\
3003 .\end{array}$ & $\begin{array}{l}2.12 \\
0.76\end{array}$ & $\begin{array}{l}4 \\
4\end{array}$ & $\begin{array}{r}111487 . \\
40094 .\end{array}$ & $\begin{array}{l}5138 . \\
1948 .\end{array}$ & $\begin{array}{l}\text { TONS } \\
\text { TONS }\end{array}$ & \\
\hline $\begin{array}{l}19 \\
20 \\
21\end{array}$ & $\begin{array}{l}1470 \\
1.037 \\
743\end{array}$ & $\begin{array}{l}37725 \\
26621 \\
19059\end{array}$ & $\begin{array}{l}9.57 \\
6.75 \\
2.90\end{array}$ & $\begin{array}{l}5 \\
5 \\
5\end{array}$ & $\begin{array}{l}169681 . \\
331427 . \\
237280 .\end{array}$ & $\begin{array}{l}21614 . \\
15273 . \\
10935 .\end{array}$ & $\begin{array}{l}\text { TONS } \\
\text { TONS } \\
\text { TONS }\end{array}$ & \\
\hline 22 & 134. & 372. & 0.25 & 1 & 6379. & $465=6$. & GAL & DIL \\
\hline $\begin{array}{l}23 \\
24\end{array}$ & $\begin{array}{l}56 . \\
21 .\end{array}$ & $\begin{array}{r}157 . \\
58\end{array}$ & $\begin{array}{l}0.11 \\
0.04\end{array}$ & $\begin{array}{l}1 \\
1\end{array}$ & $\begin{array}{r}2688 . \\
996 .\end{array}$ & $\begin{array}{r}19621 . \\
7267 .\end{array}$ & $\begin{array}{l}\text { GAL } \\
\text { GAL }\end{array}$ & $\begin{array}{l}\text { OIL } \\
\text { DIL }\end{array}$ \\
\hline 25 & 20. & 57 . & 0.04 & 1 & 969. & 7073. & GAL & DIL \\
\hline $\begin{array}{l}26 \\
27\end{array}$ & $\begin{array}{l}22 . \\
13 .\end{array}$ & $\begin{array}{l}60 . \\
37 .\end{array}$ & $\begin{array}{l}0.04 \\
0.02\end{array}$ & $\begin{array}{l}1 \\
1\end{array}$ & $\begin{array}{r}1026 . \\
638 .\end{array}$ & $\begin{array}{l}7189 . \\
4658 .\end{array}$ & $\begin{array}{l}\text { GAL } \\
\text { TiAL }\end{array}$ & $\begin{array}{l}\text { DIL } \\
\text { OIL }\end{array}$ \\
\hline 28 & 697. & 2314 & 0.54 & 1 & 31532. & 230159. & GAL & DIL \\
\hline $\begin{array}{l}29 \\
30\end{array}$ & $\begin{array}{l}361 . \\
147 .\end{array}$ & $\begin{array}{r}1197 . \\
612 .\end{array}$ & $\begin{array}{l}0.28 \\
0.87\end{array}$ & $\begin{array}{l}1 \\
1\end{array}$ & $\begin{array}{r}16314 . \\
6554 .\end{array}$ & $\begin{array}{r}119083 . \\
47836 .\end{array}$ & $\begin{array}{l}\text { GAL } \\
\text { GAL }\end{array}$ & $\begin{array}{l}\text { OIL } \\
\text { OIL }\end{array}$ \\
\hline 31 & 201 . & 887. & 0.92 & 1 & 8927. & 65163. & GAL & OIL \\
\hline 32 & 5815. & 155381 . & 2.84 & 12 & 1538272 . & 71448. & TOMS & $\mathrm{Co}$ \\
\hline 33 & 97527. & 0. & & 0 & 6545 & 259710. & RWIIA & \\
\hline 34 & 98182 & 6233751. & 97 & 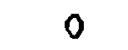 & $154:$ & 259740 & MW[IA & \\
\hline
\end{tabular}

TOTAL OPERATING COST(K\$)

TOTAL DISPATCHED ENERGY (GWE)

TOTAL IIUMFEII EMERTGY (MWE)

COST SAUINGS OF LAST WECS $(\$ / K W)$

ENERGY IIUMFEI BY ONE MORE WECS (MWE)

TOTAL WINI ENERGY FROIUCEL(MIJE)
737589.125

29865.184

0.000

70.230

0.000

820123,125
7972770. TONS COAL 554906 . GAL DIL 519179. NWIIA NUCL 
A. Operation and Outage Definftions

Annual Peak Load

Annualized Fixed Costs

Availability Factor

Avallable Hours (AH)

Average On-Line WECS Capacity

Base Load
The maxtmum integrated load over any hour in the year (MW).

The constant value of annual cost which is charged to a generating untt over its expected Iifetime. This covers the fixed costs and fixed operating costs, taking into account the cost of capital and taxes.

The ratio of time a unit is ready for or in service to the cotal time interval under consideration. For some of the computations in this study, the scheduled time maintenance for a unit reflects unava11ability of that unit; that is, Avallability Factor $=\frac{\mathrm{AH}-(\mathrm{FOH})}{\mathrm{AH}}$

The number of hours annually during which a unte is avallable; that is,

$\mathrm{AH}=\mathrm{SH}+\mathrm{RS \hat {H }}$.

The name plate rating (MW) of the average number of WECS unies which are avallable to produce power, 1.e., the WECS penetration (MW) multiplied by the average annual availability (assumed to be 0.9 for this study).

The minimum load in a stated pertod of time (MW).

\section{Source: Edison Electric Institute and Federal Power Commission.}

Note: Terms used in this report are generally consistent with those used in the JBF report, from which the bulk of this GLOSSARY was extracted. 
Base Load Plant (Unit)

Capacity

Capactey Factor

Capital Recovery Factor

Conventional Source

Demand

Diurnal Load Curve or Shape (DLS)

Dumped Power

Fixed Costs

Fixed Operating Costs

Forced Outage
A power plant which is normally operated 24 hours per day at a constant output.

The load for which a generating unft is rated (MW).

The ratto of the average annual load placed on a utility's generating equipment to the equipment's rated capacity. For WECS, the capactity factor is:

(annual energy output)

(rated power) (8760)

The uniform annual payment, as a fraction of the original principal, necessary to fully amortize a loan over a specifled period. It is a function of two variables; the relevant interest rate (cost of capital) and the specifled amortization period (Investment Iifetime).

Power generating equipment currently in utility mix.

The rate at which electric energy is delivered by a generating unit or system, expressed in megawats, at a given instant of time or averaged over a designated period of time (integrated demand, usually over a one-hour time perlod).

The curve of load versus time of occurrence presented in chronologlcal sequence over a one day period.

Power generated by unit(s) that cannot be stored or conserved and which is in excess of the utility's needs. Dumped power is considered to have no economic value to the utility.

Costs assoclated with investment in plant.

Costs other than those associated with investment in plant, which do not vary with changes in operation or utflization of plant.

The occurrence of a generating unft faflure which requires that the unit be immediately removed from service. 
Forced Outage Hours

(FOH)

Forced Outage Rates

(FOR)

Fuel Costs

Load Duration Curve (LDC)

Loss of Load Probability (LOLP)

Operat1ng Ava1lability

Operating Reserve

Peak Load

Peak Load Plant (Un1t)

Reserve Margin
Hours per annum during which a untt was unavallable due to a forced outage.

The fraction of time that a generating unit is in "non-scheduled outage" status, that is,

FOR $=\frac{\text { (Hours of Non-Scheduled Outage per Annum) }}{8760-\text { (Hours of Scheduled Outage per Annum) }}$

The additional costs of producting power above the annualized fixed costs. For gas turblines, fuel costs will include a small cost to cover maintenance which is a function of power and/or hours of operation. Fuel costs are also referred to as: dispatch costs, production costs, Incremental costs, and Incremental energy costs.

A curve of load power quantitles plotted in descending order of magnitude as a function of time intervals (one hour) for a specified period (one year).

The probability of not satisfylng the load, with generation, over a defined time period which would require disconnecting some customers. It is expressed as the number of events over a given time, and is a measure of general system rellability.

The proportion of time in a year which the unit is ava1lable $=\mathrm{AH} / 8760$.

On-line capacity in excess of load which is used to follow changes in load.

The maximum load in a stated pertod of time (NW).

A power plant which is normally operated to provide power only during maxtmum load periods.

The installed generating system capacity In excess of annual peak load which is needed as standby to Insure an adequate standard of service. 
Reserve Shutdowa Hours (RSH)

Scheduled Outage

Service Hours (SH)

Spinning Reserve
Reserve shutdown duration in hours per annum.

The shutdown of a generating unit for inspection or maintenance, in accordance with a predefined schedule.

Hours per annum that a unit was actually operated with breakers closed to the station bus.

On-I1ne and/or short start-up time capacity in excess of load and all operating reserves which is ready to take the load if an online unit should fail. 
B. WECS Terminology

WECS

WECS Availabiltty

WECS Capacity Credit

WECS Unit

WECS Installation

WECS Operating Reserve (WOR)

WECS Penetration

WECS On-LIne Levels

WECS Rated Power

Wecs Rãed Wind Speed

WECS Cut-In Wind Speed

HECS Design WInd Speed
Wind Energy Conversion System - a genertc term.

(See WECS On-Line Levels)

The Installed capacity of conventional generating units (non-WECS) which can be deleted when WECS is installed while maintaining the same level of system rellability (LOLP).

Tower and WECS machinery located on top of the tower. Costs assoclated with the WECS unit also include transportation and erection, including foundations.

Total capatilized WECS Investment Including the unit itself, transportation to the site, erecting, land purchased (or leased or obtained through easement), the cost of site land clearance and transwission electrical interface equipment (wiring, step up transformer, etc.).

On-line conventional capacicy in excess of load and operating reserve which is required to adjust for changes in weCS power resulting from - the variability in wind speet.

The amount of WECS installed capacity expressed as either "percent" or "megawatts" WECS penetration (percent) is the installed WECS capacity expressed as a percentage of utility annual peak load. (This study uses percentage of installed utility conventional (apacity.)

The amount of WECS capacity on-1ine, expressed as a percentage of the utility annual peak load or in MW. The difference between WECS penetration and WECS on-1ine levels is the avallabllity factor for WECS.

Maximum WECS output power.

U1nd speed at which weCs rated power is reached.

Wind speed at which a WECS unit first starts to produce power.

Site mean wind speed for which the WECS has been optimized based on cost of energy. 
c. WECS Study Terminology

Varlable Costs

Fixed Costs

Day Group

Phase

Fuel Saver Mode

Reoptimized Mix

Capacity Credit

OptImum WECS

Penetration Level
Costs associated with a power source that are a function of the energy it produces (mainly fuel costs).

Costs assoclated with a power source that are Incurred regardless of the energy it produces (capital costs).

A 24 hour pertod that is symbolic of similar 24 hour periods (1.e., Saturday, Sunday, etc.).

A period of time typically consisting of 28 days.. There are 13 phases that comprise a year.

When the addition of WECS is solely to save fuel and consequently no attempt is made to reoptimize the utility mix of conventlonal sources.

When the mix of conventional sources is reoptimized to minimize utility costs after WECS are added to the mix.

Value in $M$, or dollars, of conventional source that are displaced by WECS due to maintaining the same level of system rellability.

WECS penetration level at which marginal WECS cost equals marginal WECS savings and the total net present value of total WECS costs are less than the total net present value of total WECS avallable funds. 
WECS Cut-Out Wind Speed

WECS Farms
Wind speed at which WECS unit will be "feathered" and shut down to protect unft from posstble damage.

Zones where an array of WECS is to be Installed. 
D. Abbreviations

$\begin{array}{ll}\text { WECS } & \text { Wind Energy Conversion System } \\ \text { SWECS } & \text { Small Wind Energy Conversion System } \\ \text { WTG } & \text { Wind Turbine Generator } \\ \text { ICFAR } & \text { Indlanapolis Center for Advanced Research } \\ \text { PSI } & \text { Public Service Indiana } \\ \text { DEW } & \text { DeWlnkel } \\ \text { DPC } & \text { Dairyland Power Cooperative } \\ \text { JBF } & \text { JBF Scientific Corporation } \\ \text { NEGEA } & \text { New England Gas and Electric Association } \\ \text { NEPOOI } & \text { New England Power Pool } \\ \text { NEPEX } & \text { New England Power Exchange } \\ \text { SWRI } & \text { Southwest Research Institute } \\ \text { SWPS } & \text { Southwest Public Service Company } \\ \text { NCC } & \text { National Climatic Center } \\ \text { NWS } & \text { National Weather Service }\end{array}$

